\title{
Selective Separation of Lithium Chloride from Related Metal Chlorides by Organogels Containing Strapped Calix[4]pyrroles
}

Hu Wang, ${ }^{\dagger}$ Leighton O. Jones, ${ }^{\ddagger}$ Inhong Hwang, ${ }^{\dagger}$ Marshall Allen, ${ }^{\dagger,} "$ Daliao Tao, ${ }^{\dagger}$ Vincent M. Lynch, ${ }^{\dagger}$ Benny D. Freeman, Niveen M. Khashab, ${ }^{\S}$ George C. Schatz, ${ }^{* \dagger}$ Zachariah A. Page, ${ }^{* \dagger}$ and Jonathan L. Sessler*,†

${ }^{\dagger}$ Department of Chemistry, 105 East 24th Street, Stop A5300, The University of Texas at Austin, Austin, Texas 78712, United States. Email: sessler@cm.utexas.edu; zpage@cm.utexas.edu

tDepartment of Chemistry, Northwestern University, Evanston, Illinois 60208, United States. Email: gschatz@northwestern.edu

${ }^{\S}$ Smart Hybrid Materials (SHMs) Laboratory Advanced Membranes and Porous Materials Center King Abdullah University of Science and Technology Thuwal, 23955, Saudi Arabia.

"McKetta Department of Chemical Engineering, University of Texas at Austin, Austin, TX 78712, USA.

\section{Supporting Information (88 Pages)}

1. Materials and methods

2. Synthetic route of compound $\boldsymbol{H} \mathbf{1}$ and $\boldsymbol{H} \mathbf{2}$

3. Preparation of H1-monomer, $\boldsymbol{H} 2$-monomer, gel $\mathbf{G 1}$, gel $\mathbf{G} \mathbf{2}$, and $\boldsymbol{G}$-control

4. Host-guest interactions of $\boldsymbol{H} \mathbf{1}$ and $\mathbf{H} \mathbf{2}$ with $\mathrm{LiCl}$ respectively

5. Determination of the association constants of $\mathbf{H} \mathbf{1} د \mathrm{LiCl}$ and $\mathbf{H} \mathbf{2} د \mathrm{LiCl}$

6. Interactions of $\boldsymbol{H 2}$-monomer in nitrotoluene or $\boldsymbol{H} \mathbf{2}$ in acetonitrile with various salts ( $\mathrm{LiCl}, \mathrm{NaCl}, \mathrm{KCl}, \mathrm{MgCl}_{2}$, and $\mathrm{CaCl}_{2}$ alone and in combination)

7. ICP-MS result before and after adding small molecules

8. Interactions of $\mathbf{H 1}$ with $\mathrm{LiCl}, \mathrm{NaCl}, \mathrm{KCl}, \mathrm{MgCl}_{2}$ and $\mathrm{CaCl}_{2}$

9. Interactions of $\mathbf{H} 2$ with $\mathrm{LiCl}, \mathrm{NaCl}, \mathrm{KCl}, \mathrm{MgCl}_{2}$ and $\mathrm{CaCl}_{2}$

10. Summary of the selectivity of $\mathbf{H 1} / \mathbf{H} 2$ to $\mathrm{LiCl}$

11. Competitive complexation of $\mathbf{H} \mathbf{1}$ and $\mathbf{H} \mathbf{2}$ to $\mathrm{LiCl}$

12. The interactions between H1-monomer and $\mathrm{LiPF}_{6}$ or $\mathrm{NaPF}_{6}$ in $\mathrm{CD}_{3} \mathrm{CN}$ or nitrobenzene- $d_{6}$

13. IR spectra of $\boldsymbol{H 1}$-monomer, $\boldsymbol{H 1}$-monomer, $\boldsymbol{G}$-control, $\boldsymbol{G} \mathbf{1}$, and $\boldsymbol{G} \mathbf{2}$

14. Thermogravimetric analysis of $\boldsymbol{P} \mathbf{1}, \boldsymbol{P} \mathbf{2}$, and $\boldsymbol{P}$-control

15. Mechanical characterization of $\boldsymbol{G 1}, \boldsymbol{G} 2$, and $\boldsymbol{G}$-control

16. ${ }^{1} \mathrm{H} N M R$ spectra of $\boldsymbol{H 1}$ and $\boldsymbol{H} \mathbf{2}+\mathrm{LiCl}$ recorded in methanol-d $\mathrm{d}_{4}$

17. Conductivity vs concentration studies for various metal salt solutions in acetonitrile and methanol

18. Changes in conductivity of solutions wherein metal salts are extracted in acetonitrile and released in methanol 
19. ICP-MS results before extracting and after releasing treated by $\boldsymbol{P} 1$ or $\boldsymbol{P} 2$

20. Regeneration and reuse of the polymer network $\boldsymbol{P} 1$ and $\boldsymbol{P 2}$

21. The photographs of $\mathbf{P 1 / P 2}$ before and after extraction of $\mathrm{LiCl}$

22. X-ray experimental

23. Computational Methods

24. Computational Data

S 80

25. Supplementary references 


\section{Materials and methods}

All reagents and starting materials were obtained from commercial suppliers and used without further purification unless otherwise noted. Compounds $\mathbf{1}^{\mathrm{S} 1}$ and $\mathbf{2}^{\mathrm{S} 2}$ was prepared according to published procedures. One-dimensional nuclear magnetic resonance (NMR) spectra were recorded on Agilent MR 400 and Varian Inova 500 instruments. ESI mass spectra were obtained on an Agilent Technologies 6530 Accurate-Mass Q-TOF LC/MS or a Thermo Scientific TSQ Quantum GC/MS. The Fourier transform infrared (FTIR) spectrum of the hydrogels were recorded by using an FTIR spectrometer (Thermo Mattson, Infinity Gold FTIR) equipped with a liquid nitrogen cooled narrow band MCT detector. An attenuated total reflection cell equipped with a Ge crystal was employed. Scanning electron microscopy (SEM) investigations were carried out on a HITACHI S-5500 SEM/STEM instrument. The conductivity of solutions was determined on a DDS-307 instrument. Rheological experiments were performed using a rheometer (HR-2 discovery hybrid rheometer) with an $8.0 \mathrm{~mm}$ parallel plate in the frequency sweep mode $\left(25^{\circ} \mathrm{C}\right)$. Compression tests were performed using HR-2 discovery hybrid rheometer. 


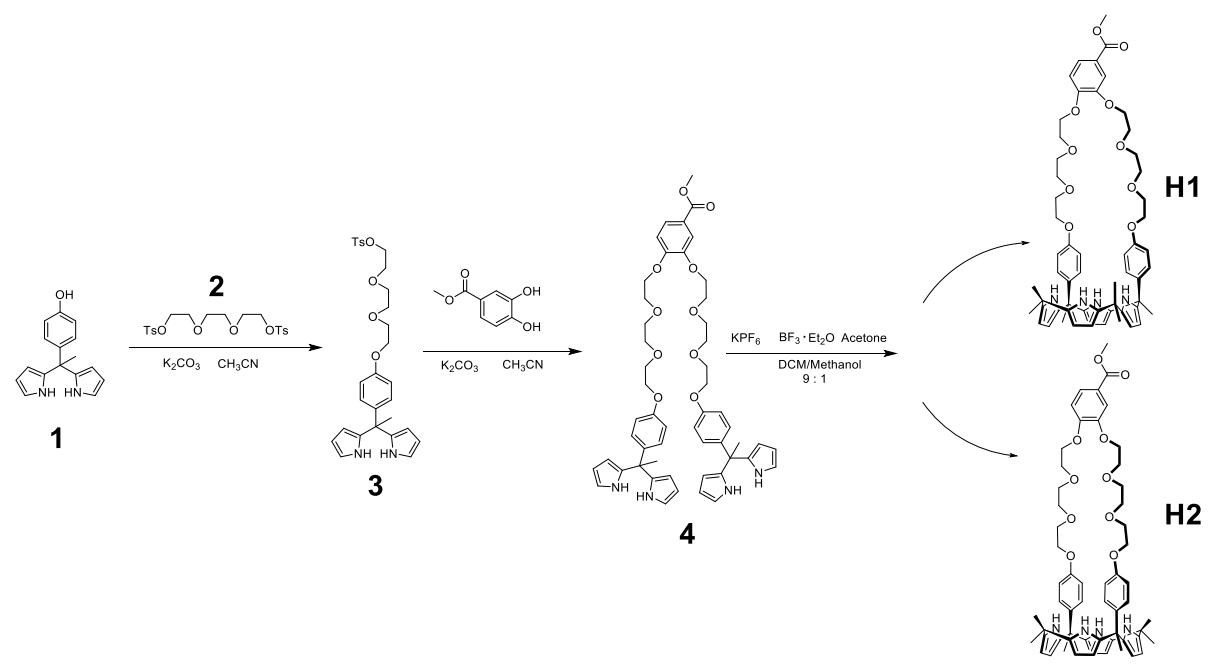

Figure S1. Synthetic route to strapped calix[4]pyrroles $\mathbf{H 1}$ and $\mathbf{H 2}$.

\subsection{Synthesis of compound 3}
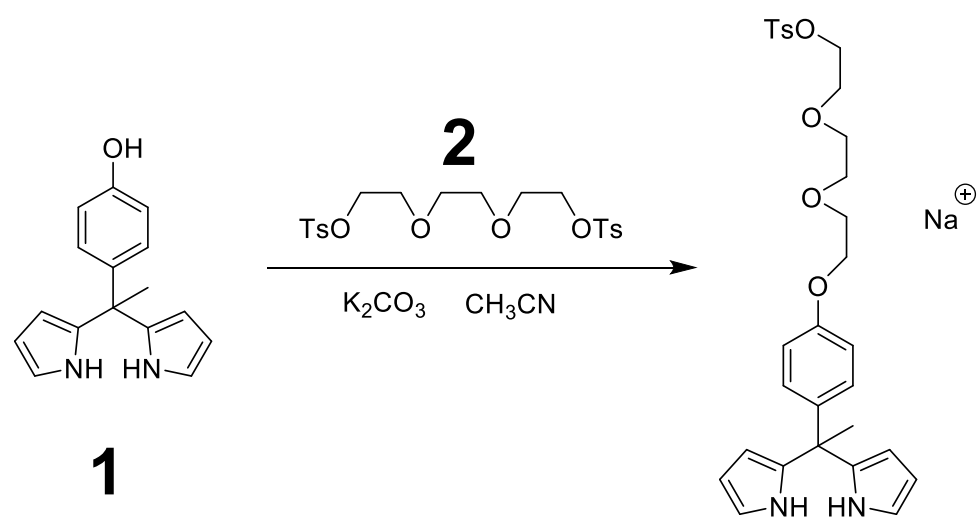

3

In a $500 \mathrm{~mL}$ round-bottomed flask equipped with a condenser and magnetic stirrer, compound $\mathbf{1}^{\mathrm{S1}}$ (30.0 g, $\left.119 \mathrm{mmol}\right)$, compound $2^{\mathrm{S} 2}$ (164 g, $\left.357 \mathrm{mmol}\right)$, and $\mathrm{K}_{2} \mathrm{CO}_{3}(49.3 \mathrm{~g}, 357 \mathrm{mmol})$ were added to $\mathrm{CH}_{3} \mathrm{CN}(250 \mathrm{~mL})$. The flask was evacuated and then nitrogen was introduced. After this process had been carried out three times, the mixture was stirred for 24 hours in an oil bath at $85{ }^{\circ} \mathrm{C}$ under vigorous stirring. After allowing to cool to room temperature, the mixture was filtered, and the filtrate was concentrated under reduced pressure. The resulting residue was purified by flash column chromatography over silica gel (ethyl acetate/ hexanes 1:3, eluent) to give $3(24.1 \mathrm{~g}, 30.1 \%)$ as a yellow oil. The ${ }^{1} \mathrm{H}$ NMR spectrum of compound 3 is shown in Figure S2. ${ }^{1} \mathrm{H}$ NMR (400 MHz, DMSO- $\left.d_{6}, 298 \mathrm{~K}\right) \delta(\mathrm{ppm})$ : $10.26(\mathrm{~d}, 2.0 \mathrm{~Hz}, 2 \mathrm{H}), 7.77-7.71(\mathrm{~m}, 2 \mathrm{H}), 7.43(\mathrm{~d}, 8.0 \mathrm{~Hz}, 2 \mathrm{H}), 6.81(\mathrm{~s}, 2 \mathrm{H}), 6.77$ (s, 2H), 6.59 (dd, 4.3, 2.6 Hz, 2H), $5.84(\mathrm{~m}, 2 \mathrm{H}), 5.49(\mathrm{~m}, 2 \mathrm{H}), 4.10-4.05(\mathrm{~m}, 2 \mathrm{H}), 4.01-3.95(\mathrm{~m}, 3 \mathrm{H}), 3.65(\mathrm{~m}, 2 \mathrm{H}), 3.56-3.52(\mathrm{~m}, 2 \mathrm{H}), 3.49-3.45(\mathrm{~m}$, $2 \mathrm{H}), 3.45-3.41(\mathrm{~m}, 3 \mathrm{H}), 2.36(\mathrm{~s}, 3 \mathrm{H}), 1.88(\mathrm{~s}, 3 \mathrm{H})$. The ${ }^{13} \mathrm{C}$ NMR spectrum of $\mathbf{3}$ is shown in Figure S3. ${ }^{13} \mathrm{C}$ NMR (400 MHz, DMSO- $d_{6}, 298$ K) $\delta$ (ppm): 138.3, 130.6, 128.6, 128.0, 125.9, 117.5, 113.9, 106.6, 106.2, 70.4, 70.1, 69.4, 67.4, 43.9, 40.5, 40.25, 40.0, 39.8, 39.6, 39.4, 39.2. The HR ESI-MS trace for 3 is shown in Figure. S4: $\mathrm{m} / \mathrm{z}$ calcd for $[\mathrm{M}+\mathrm{H}]^{+}\left[\mathrm{C}_{29} \mathrm{H}_{34} \mathrm{~N}_{2} \mathrm{O}_{6} \mathrm{~S}+\mathrm{H}\right]^{+}, 539.2210$; found 539.2220; error -1.74 ppm. 


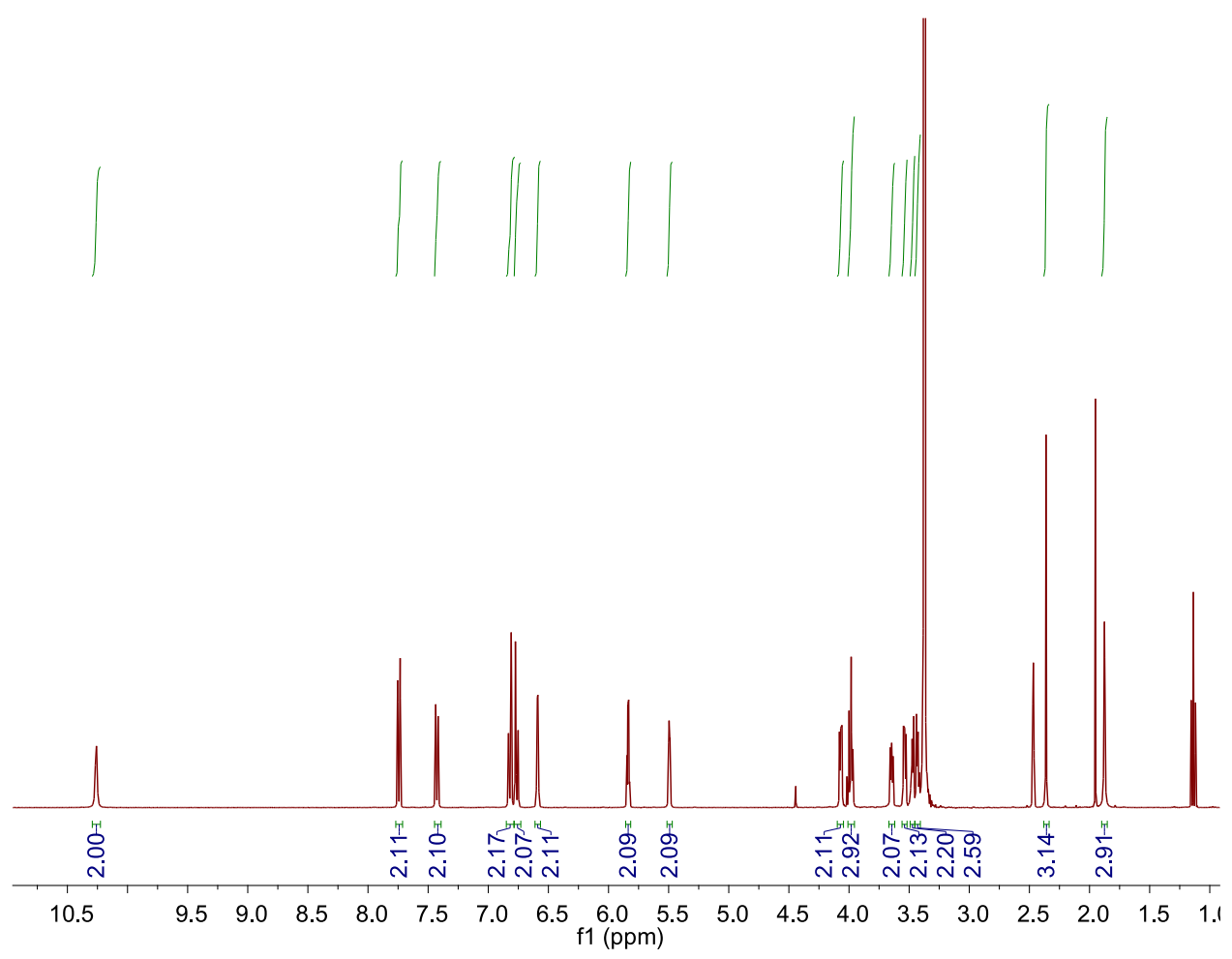

Figure S2. ${ }^{1} \mathrm{H}$ NMR spectrum (400 MHz, DMSO- $d_{6}, 298 \mathrm{~K}$ ) of compound 3.

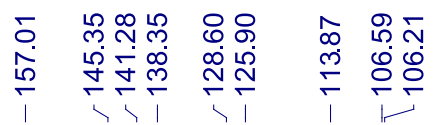
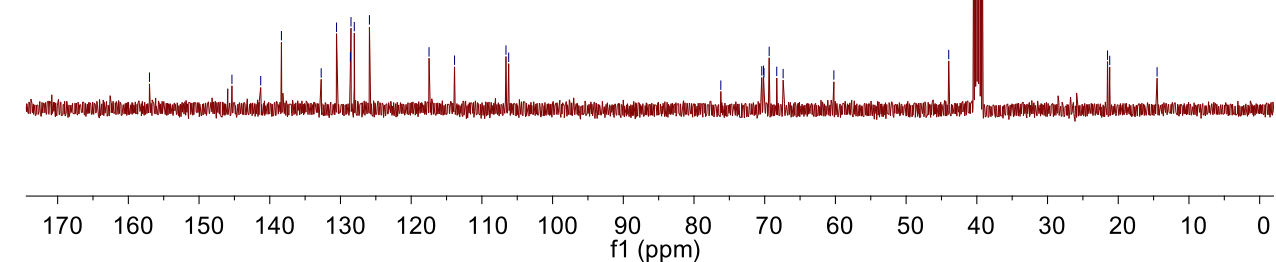

Figure S3. ${ }^{13} \mathrm{C}$ NMR spectrum (400 MHz, DMSO- $\left.d_{6}, 298 \mathrm{~K}\right)$ of compound 3. 


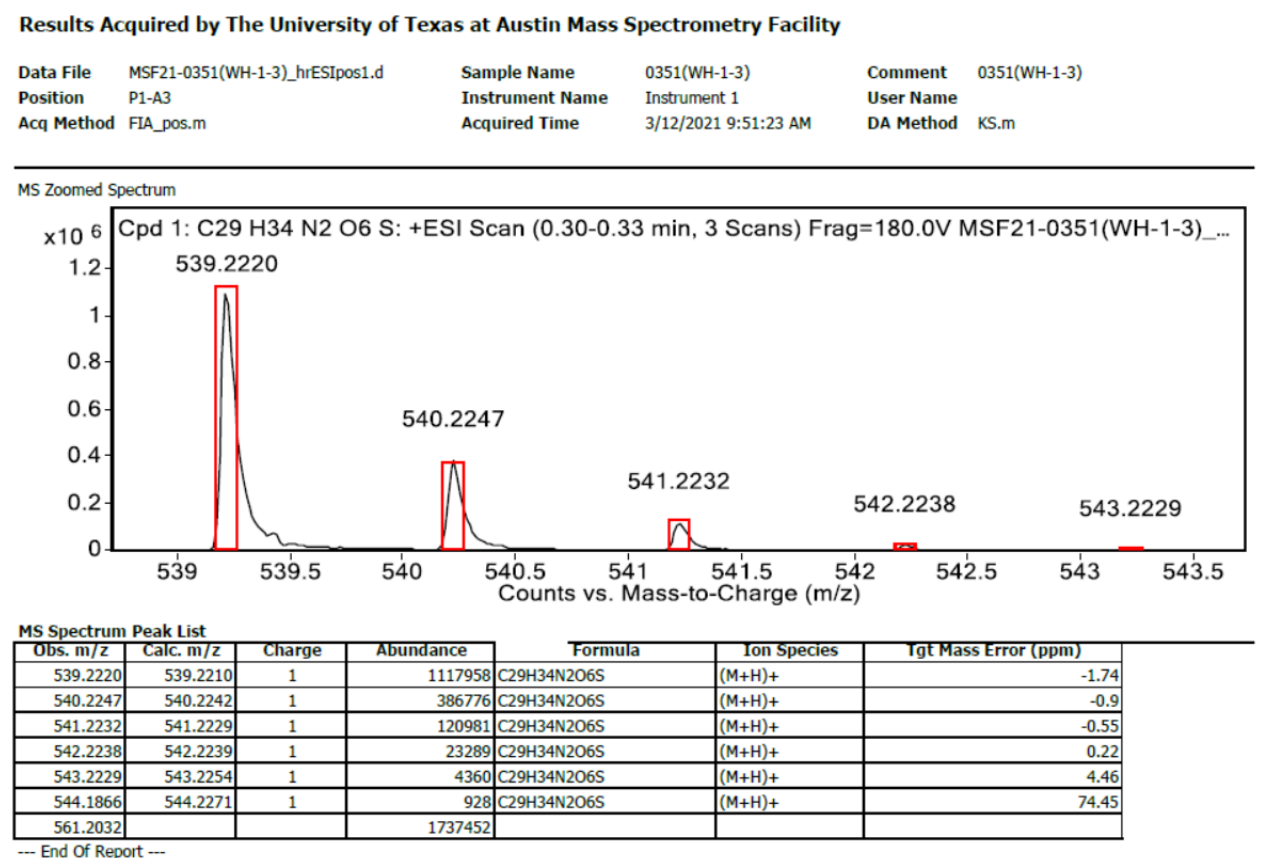

Figure S4. HR-ESI mass spectrum of compound 3.

\subsection{Synthesis of compound 4}
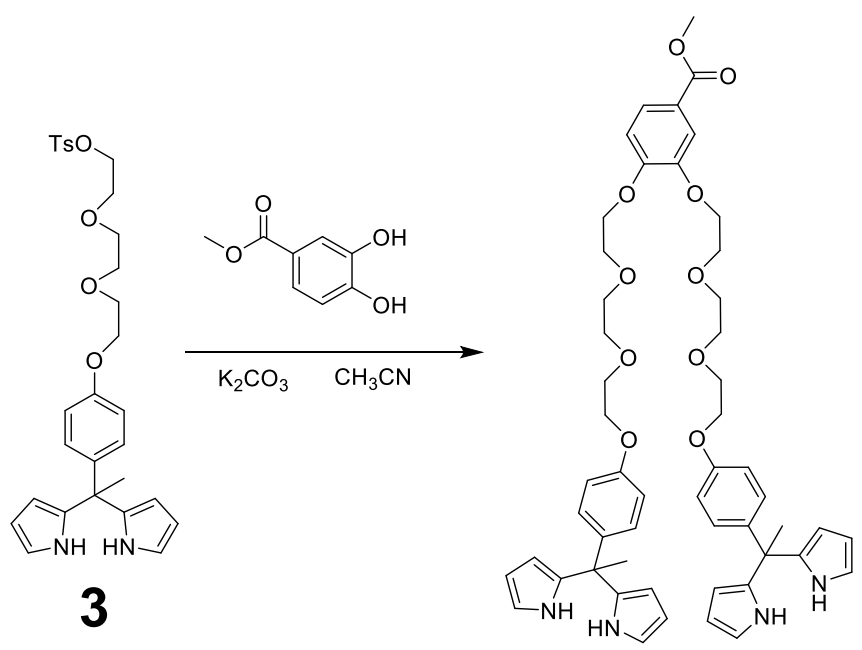

4

In a $500 \mathrm{~mL}$ round-bottomed flask equipped with a condenser and magnetic stirrer, compound $\mathbf{3}$ (24.0 g, $44.6 \mathrm{mmol})$, methyl 3,4-dihydroxybenzoate (3.75 g, $22.3 \mathrm{mmol})$, and $\mathrm{K}_{2} \mathrm{CO}_{3}(18.5 \mathrm{~g}, 134 \mathrm{mmol})$ were added to $\mathrm{CH}_{3} \mathrm{CN}(250 \mathrm{~mL})$. The flask was evacuated and then nitrogen was introduced. After this process had been carried out three times, the mixture was stirred for 24 hours in an oil bath at $85{ }^{\circ} \mathrm{C}$ under vigorous stirring. After allowing to cool to room temperature, the mixture was filtered and the filtrate was concentrated under reduced pressure. The residue obtained in this way was purified by flash column chromatography over silica gel (ethyl acetate/hexanes 1:2, eluent) to give 4 (18.1 g, 45.0\%) as a yellow oil. The ${ }^{1} \mathrm{H}$ NMR spectrum of compound 4 is shown in Figure S5. ${ }^{1} \mathrm{H}$ NMR (400 MHz, 
DMSO- $\left.d_{6}, 298 \mathrm{~K}\right) \delta(\mathrm{ppm}): 10.26(\mathrm{~d}, 2.1 \mathrm{~Hz}, 4 \mathrm{H}), 7.52(\mathrm{~m}, 1 \mathrm{H}), 7.44(\mathrm{~d}, 2.0 \mathrm{~Hz}, 1 \mathrm{H}), 7.05(\mathrm{~d}, 8.5 \mathrm{~Hz}, 0 \mathrm{H}), 6.83-$ $6.79(\mathrm{~m}, 1 \mathrm{H}), 6.76(\mathrm{t}, 7.3 \mathrm{~Hz}, 1 \mathrm{H}), 6.58(\mathrm{~m}, 1 \mathrm{H}), 5.83(\mathrm{~m}, 1 \mathrm{H}), 5.48(\mathrm{~m}, 1 \mathrm{H}), 4.15-4.06(\mathrm{~m}, 1 \mathrm{H}), 3.98(\mathrm{~d}, 7.0 \mathrm{~Hz}$, $1 \mathrm{H}), 3.76(\mathrm{~s}, 1 \mathrm{H}), 3.71(\mathrm{~m}, 1 \mathrm{H}), 3.69-3.65(\mathrm{~m}, 1 \mathrm{H}), 3.60-3.57(\mathrm{~m}, 1 \mathrm{H}), 3.55(\mathrm{~d}, 4.7 \mathrm{~Hz}, 1 \mathrm{H}), 1.87(\mathrm{~s}, 2 \mathrm{H})$. The ${ }^{13} \mathrm{C}$ NMR spectrum of 3 is shown in Figure S6. ${ }^{13} \mathrm{C}$ NMR (400 MHz, DMSO- $\left.d_{6}, 298 \mathrm{~K}\right) \delta(\mathrm{ppm}): 157.0,154.2,148.8$, $141.3,138.3,129.9,128.5,117.4,113.9,106.2,70.4,69.2,68.6,67.4,43.9,28.7$. The HR ESI-MS trace for 4 is shown in Figure $\mathrm{S} 7: \mathrm{m} / \mathrm{z}$ calcd for $[\mathrm{M}+\mathrm{Na}]^{+}\left[\mathrm{C}_{52} \mathrm{H}_{60} \mathrm{~N}_{4} \mathrm{O}_{10}+\mathrm{Na}\right]^{+}, 923.4202$; found 923.4195; error $0.74 \mathrm{ppm}$.

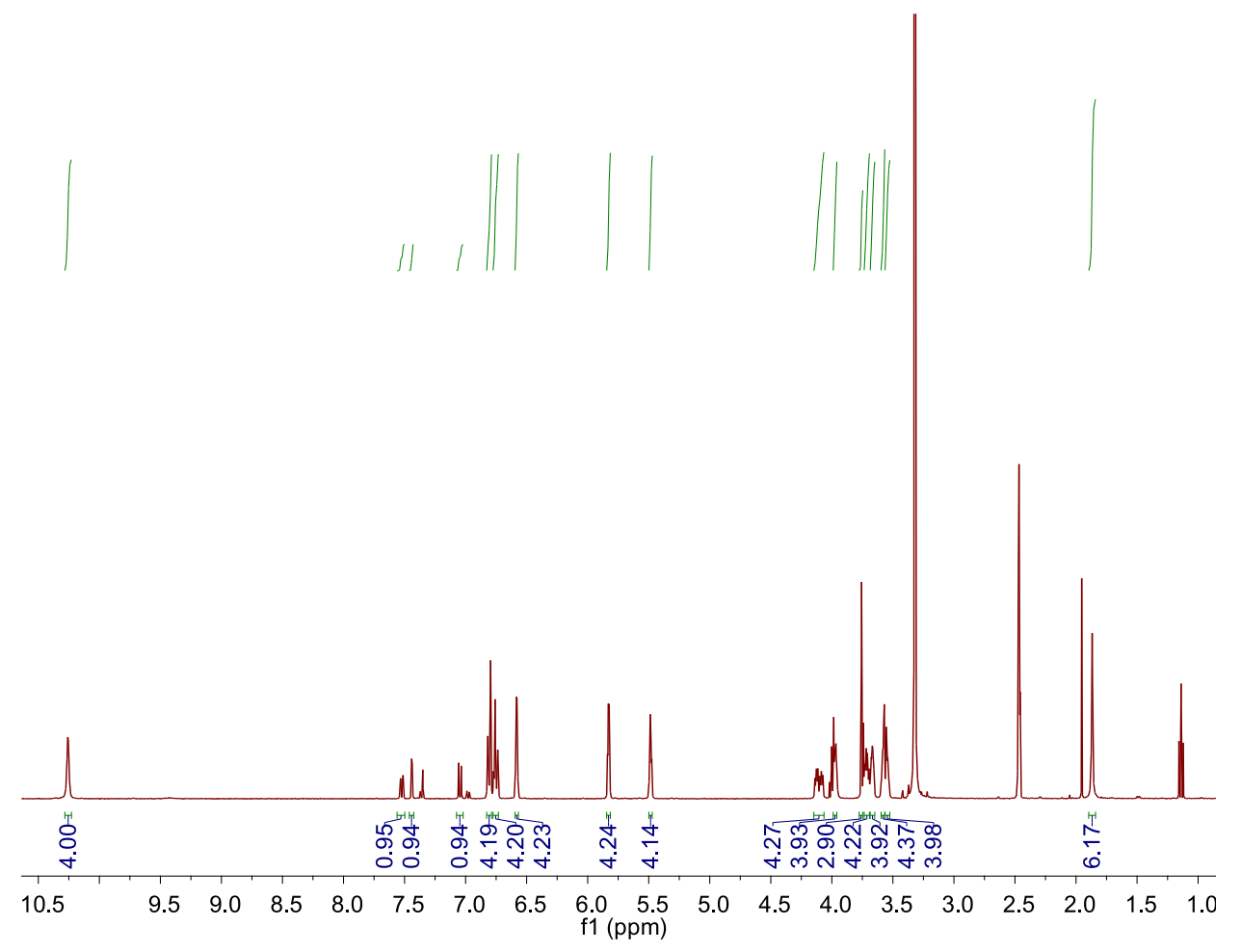

Figure S5. ${ }^{1} \mathrm{H}$ NMR spectrum (400 MHz, DMSO- $\left.d_{6}, 298 \mathrm{~K}\right)$ of compound 4. 


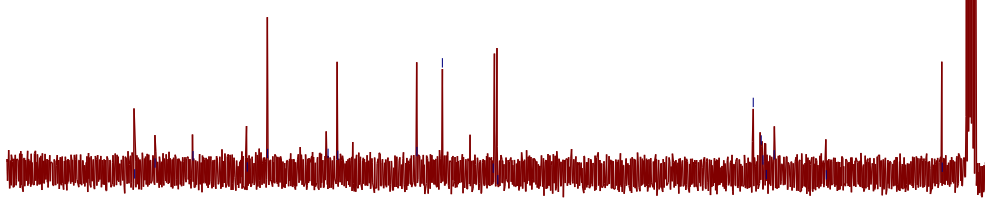

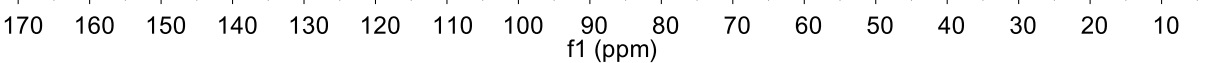

Figure S6. ${ }^{13} \mathrm{C}$ NMR spectrum $\left(400 \mathrm{MHz}, \mathrm{DMSO}-d_{6}, 298 \mathrm{~K}\right)$ of compound 4.

\section{Target Compound Screening Report}

Results Acquired by The University of Texas at Austin Mass Spectrometry Facility

$\begin{array}{llllll}\text { Data File } & \text { MSF21-0352(WH-1-4)_hrESIpos1.d } & \text { Sample Name } & \text { 0352(WH-1-4) } & \text { Comment } & \text { 0352(WH-1-4) } \\ \text { Position } & \text { P1-A4 } & \text { Instrument Name } & \text { Instrument 1 } & \text { User Name } & \text { KS.M } \\ \text { Acq Method } & \text { FIA_pos.m } & \text { Acquired Time } & \text { 3/12/2021 9:52:18 AM } & \text { DA Method } & \text { KS.m }\end{array}$

Acq Method FIA_pos.m

Acquired Time

DA Method KS

MS Zoomed Spectrum

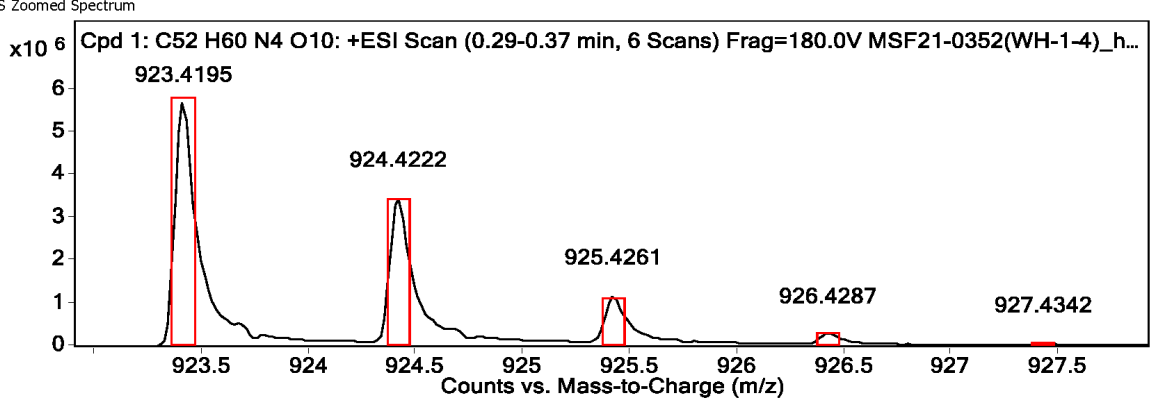

\begin{tabular}{|c|c|c|c|c|c|c|}
\hline Obs. m/z & Calc. $\mathbf{m} / \mathbf{z}$ & Charge & Abundance & Formula & Ion Species & Tgt Mass Error (ppm) \\
\hline 923.4195 & 923.4202 & 1 & 5693204 & $\mathrm{C} 52 \mathrm{H} 60 \mathrm{~N} 4010$ & $(M+N a)+$ & 0.74 \\
\hline 924.4222 & 924.4234 & 1 & 3443755 & C52H6ON4O1O & $(\mathrm{M}+\mathrm{Na})+$ & 1.26 \\
\hline 925.4261 & 925.4264 & 1 & 1159843 & $\mathrm{C} 52 \mathrm{H} 60 \mathrm{~N} 4 \mathrm{O} 10$ & $(\mathrm{M}+\mathrm{Na})+$ & 0.29 \\
\hline 926.4287 & 926.4293 & 1 & 251962 & C52H60N4O10 & $(M+N a)+$ & 0.66 \\
\hline 927.4342 & 927.4320 & 1 & 44146 & $\mathrm{C} 52 \mathrm{H} 60 \mathrm{~N} 4 \mathrm{O} 10$ & $(\mathrm{M}+\mathrm{Na})+$ & -2.28 \\
\hline 928.4363 & 928.4348 & 1 & 6758 & $\mathrm{C} 52 \mathrm{H} 60 \mathrm{~N} 4010$ & $(\mathrm{M}+\mathrm{Na})+$ & -1.67 \\
\hline
\end{tabular}

Figure S7. HR-ESI mass spectrum of compound 4. 

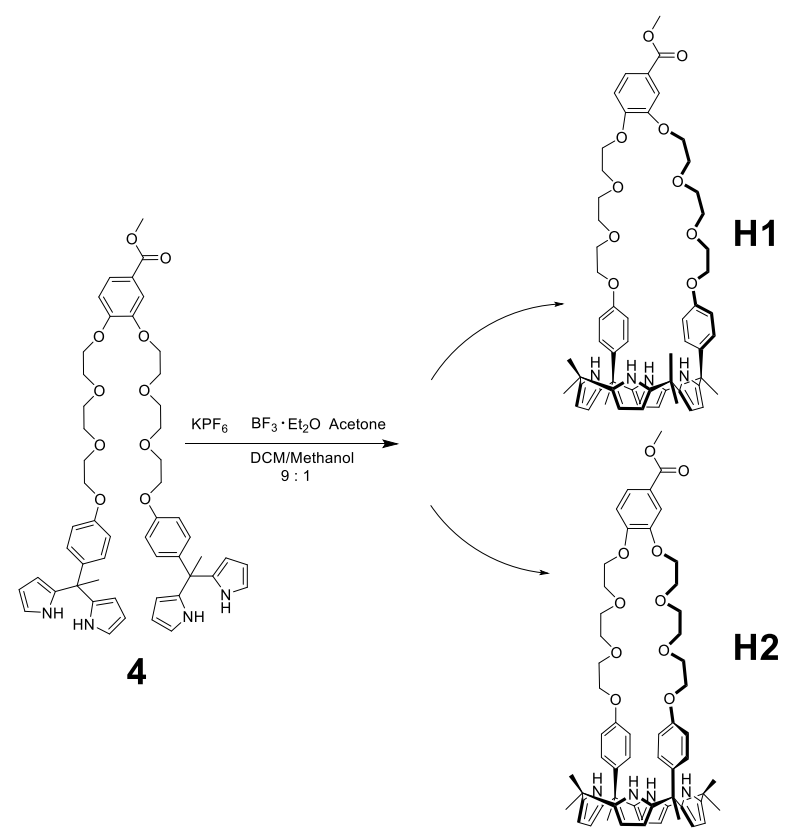

In a $500 \mathrm{~mL}$ round-bottomed flask equipped with a condenser and magnetic stirrer, compound 4 (18.0 g, $20.0 \mathrm{mmol})$, $\mathrm{KPF}_{6}(7.36 \mathrm{~g}, 40.0 \mathrm{mmol})$, boron trifluoride ethyl etherate $(3.0 \mathrm{ml})$, and acetone $(20 \mathrm{ml})$ were added to the $4 \mathrm{~L}$ mixed solvent dichloromethane (DCM)/methanol (9:1). The mixture was then stirred for 48 hours at room temperature. The mixture was then concentrated under reduced pressure. The residue obtained in this way was purified by flash column chromatography over silica gel (ethyl acetate/ hexanes 1:1, eluent) to give H1 (2.94 g, 15.0\%) and H2 (3.92 g, 20.0\%) as a yellow oil. The ${ }^{1} \mathrm{H}$ NMR spectrum of compound $\mathbf{H 1}$ is shown in Figure S8. ${ }^{1} \mathrm{H}$ NMR $\left(400 \mathrm{MHz}, \mathrm{CD}_{3} \mathrm{CN}, 298\right.$ K) $\delta(\mathrm{ppm}): 8.15(\mathrm{~s}, 1 \mathrm{H}), 7.90(\mathrm{~s}, 1 \mathrm{H}), 7.77(\mathrm{~s}, 2 \mathrm{H}), 7.63(\mathrm{~m}, 1 \mathrm{H}), 7.55(\mathrm{~d}, 2.0 \mathrm{~Hz}, 1 \mathrm{H}), 7.01(\mathrm{~d}, 8.5 \mathrm{~Hz}, 1 \mathrm{H}), 6.79(\mathrm{~s}$, $8 \mathrm{H}), 5.96(\mathrm{~d}, 2.7 \mathrm{~Hz}, 2 \mathrm{H}), 5.85(\mathrm{~d}, 2.7 \mathrm{~Hz}, 4 \mathrm{H}), 5.73(\mathrm{~m}, 2 \mathrm{H}), 4.20-4.16(\mathrm{~m}, 5 \mathrm{H}), 4.05(\mathrm{t}, 4.6 \mathrm{~Hz}, 4 \mathrm{H}), 3.83(\mathrm{~s}, 7 \mathrm{H})$, $3.77(\mathrm{~m}, 4 \mathrm{H}), 3.69(\mathrm{~s}, 4 \mathrm{H}), 3.67(\mathrm{~s}, 4 \mathrm{H}), 1.81(\mathrm{~s}, 6 \mathrm{H}), 1.52(\mathrm{~s}, 6 \mathrm{H}), 1.44(\mathrm{~s}, 6 \mathrm{H})$. The ${ }^{13} \mathrm{C}$ NMR spectrum of $\mathbf{H 1}$ is shown in Figure S9. ${ }^{13} \mathrm{C}$ NMR (400 MHz, $\left.\mathrm{CD}_{3} \mathrm{CN}, 298 \mathrm{~K}\right) \delta(\mathrm{ppm}): 166.38,157.10,152.79,148.19,141.38,139.83$, 138.08, 136.26, 128.69, 123.57, 114.00, 113.50, 112.40, 105.00, 103.79, 103.37, 102.37-102.17, 70.49, 69.22, 68.78, 67.38, 51.53, 43.80, 35.10, 30.32, 29.14, 27.50. The HR ESI-MS trace for $\mathbf{H 1}$ is shown in Fig. S10: $\mathrm{m} / \mathrm{z}$ calcd for [M $+\mathrm{Na}]^{+} \mathrm{C}_{58} \mathrm{H}_{68} \mathrm{~N}_{4} \mathrm{O}_{10}{ }^{+}, 1003.4828$; found 1003.4826; error $0.13 \mathrm{ppm}$. The ${ }^{1} \mathrm{H}$ NMR spectrum of compound $\mathbf{H 2}$ is shown in Figure S11. ${ }^{1} \mathrm{H}$ NMR (400 MHz, $\left.\mathrm{CD}_{3} \mathrm{CN}, 298 \mathrm{~K}\right) \delta(\mathrm{ppm}): 8.06(\mathrm{~s}, 4 \mathrm{H}), 7.61(\mathrm{~m}, 1 \mathrm{H}), 7.56(\mathrm{~d}, 2.0 \mathrm{~Hz}, 1 \mathrm{H})$, $7.00(\mathrm{~d}, 8.3 \mathrm{~Hz}, 0 \mathrm{H}), 6.81(\mathrm{~d}, 2.3 \mathrm{~Hz}, 2 \mathrm{H}), 5.79-5.72(\mathrm{~m}, 2 \mathrm{H}), 4.17-4.11(\mathrm{~m}, 1 \mathrm{H}), 4.10-4.07(\mathrm{~m}, 1 \mathrm{H}), 3.84(\mathrm{~s}, 1 \mathrm{H})$, $3.77(\mathrm{~m}, 2 \mathrm{H}), 3.63(\mathrm{~s}, 2 \mathrm{H}), 1.82(\mathrm{~s}, 2 \mathrm{H}), 1.63(\mathrm{~s}, 2 \mathrm{H}), 1.44(\mathrm{~s}, 2 \mathrm{H})$. The ${ }^{13} \mathrm{C}$ NMR spectrum of $\mathbf{H 2}$ is shown in Figure S12. ${ }^{13} \mathrm{C}$ NMR $\left(400 \mathrm{MHz}, \mathrm{CD}_{3} \mathrm{CN}, 298 \mathrm{~K}\right) \delta$ (ppm): 157.2, 140.8, 139.0, 137.3, 128.5, 123.6, 113.6, 112.8, 104.8, 70.4, 69.4, 69.0, 68.5, 68.3, 67.3, 43.8, 34.6, 29.9, 28.7, 26.6. The HR ESI-MS trace for $\mathbf{H 2}$ is shown in Fig. S13: $\mathrm{m} / \mathrm{z}$ calcd for $[\mathrm{M}+\mathrm{Na}]^{+} \mathrm{C}_{58} \mathrm{H}_{68} \mathrm{~N}_{4} \mathrm{O}_{10}{ }^{+}, 1003.4828$; found 1003.4833; error $-0.52 \mathrm{ppm}$. 


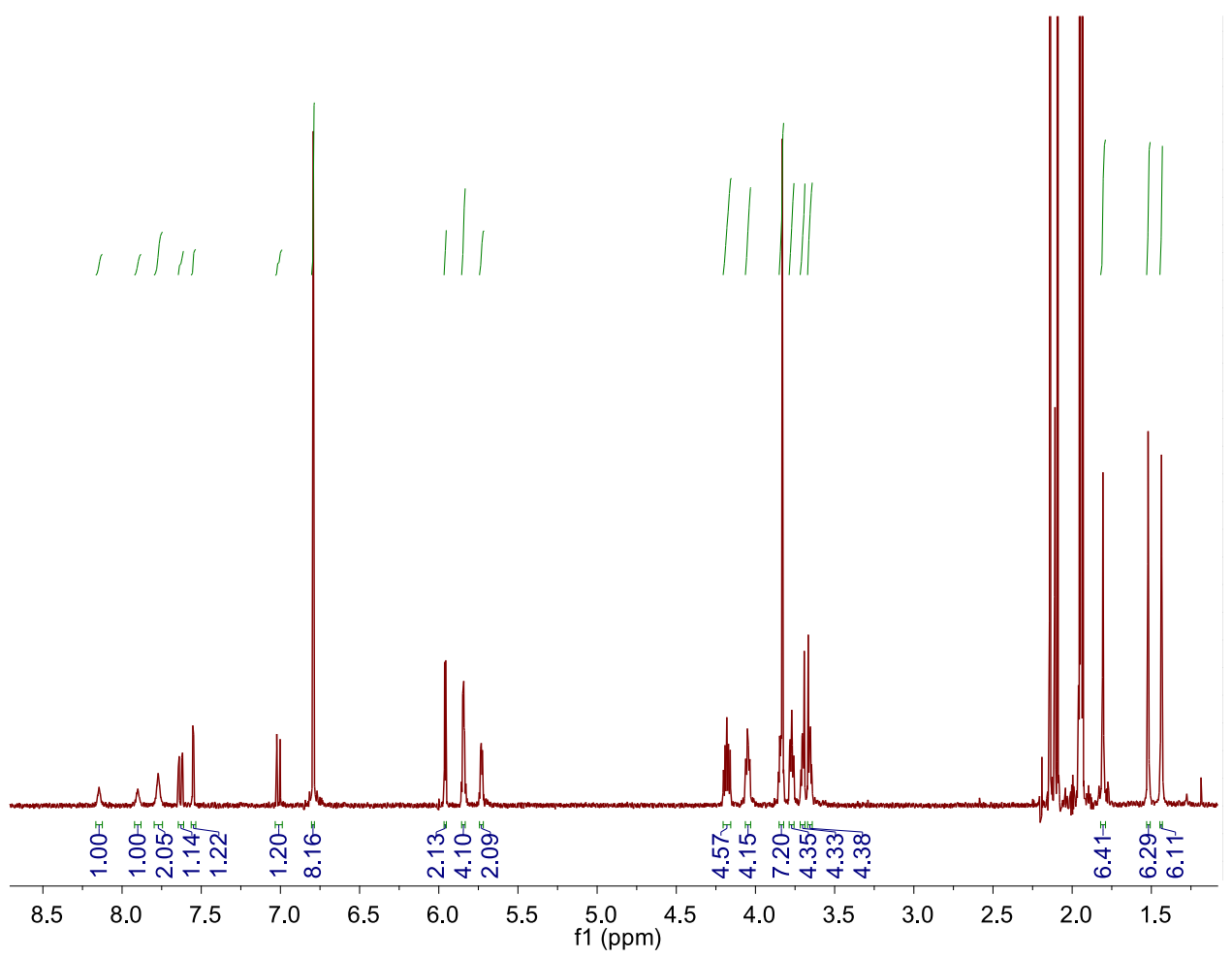

Figure S8. ${ }^{1} \mathrm{H}$ NMR spectrum $\left(400 \mathrm{MHz}, \mathrm{CD}_{3} \mathrm{CN}, 298 \mathrm{~K}\right)$ of compound $\mathbf{H 1}$.

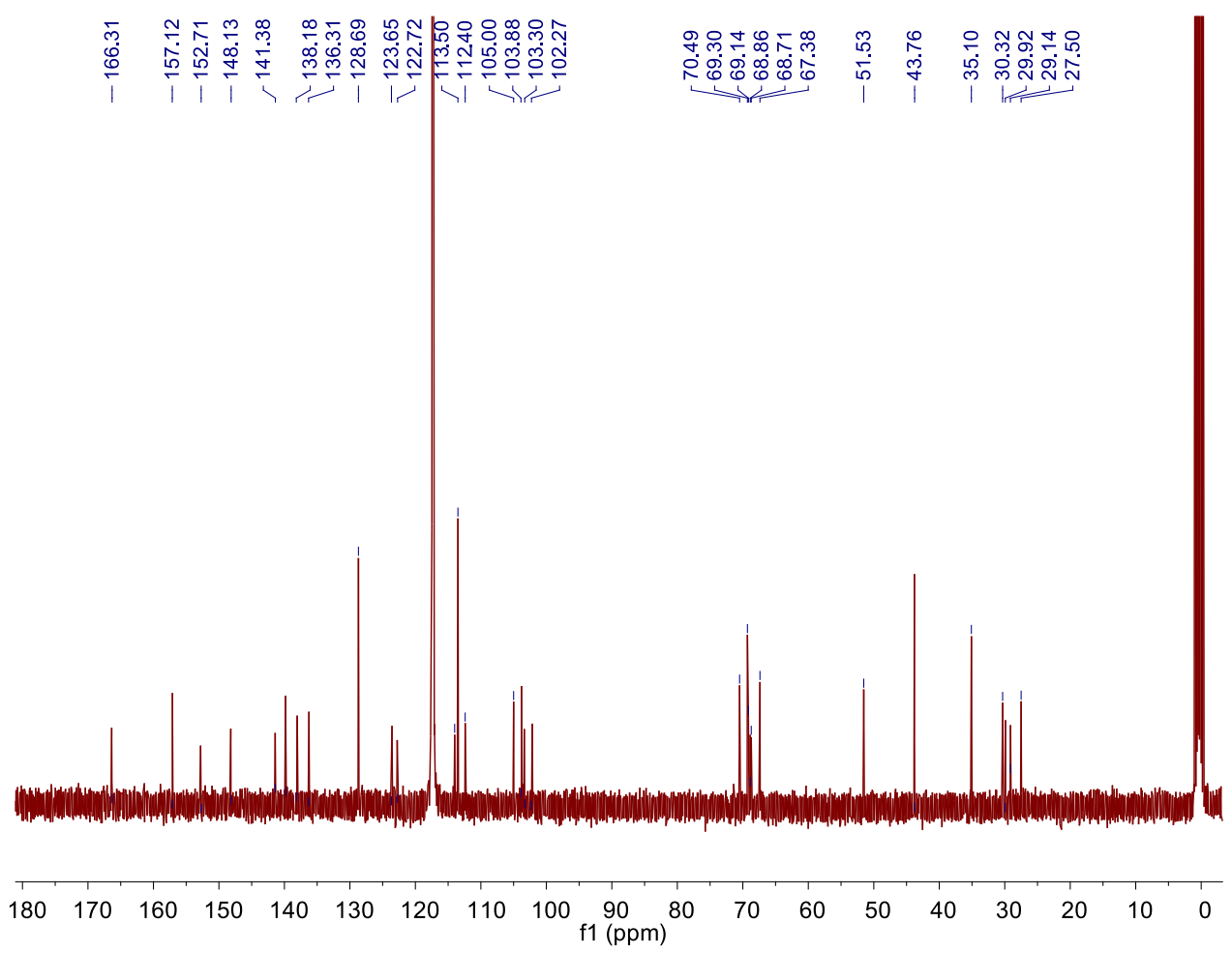

Figure S9. ${ }^{13} \mathrm{C}$ NMR spectrum $\left(400 \mathrm{MHz}, \mathrm{CD}_{3} \mathrm{CN}, 298 \mathrm{~K}\right)$ of compound $\mathbf{H 1}$. 
Target Compound Screening Report

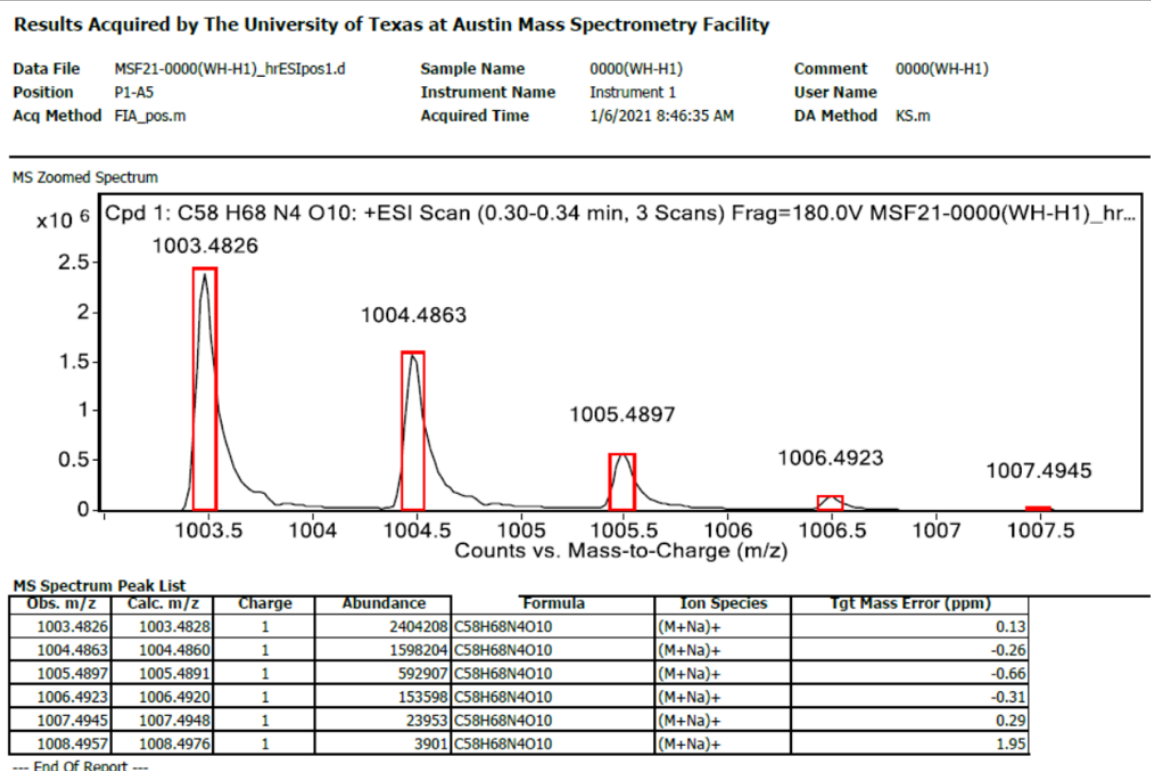

Figure S10. HR-ESI mass spectrum of compound H1.

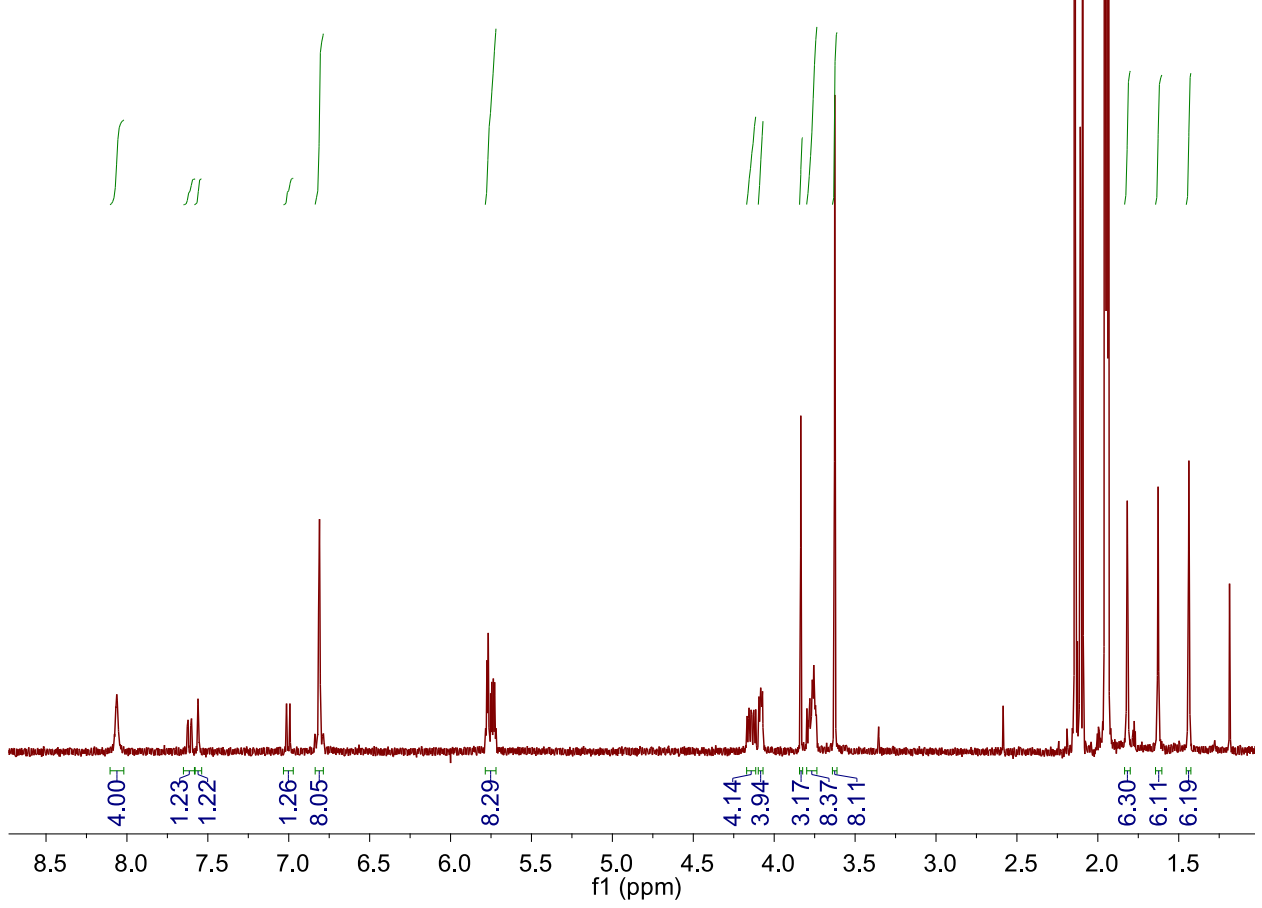

Figure S11. ${ }^{1} \mathrm{H}$ NMR spectrum (400 MHz, $\left.\mathrm{CD}_{3} \mathrm{CN}, 298 \mathrm{~K}\right)$ of compound $\mathbf{H 2}$. 


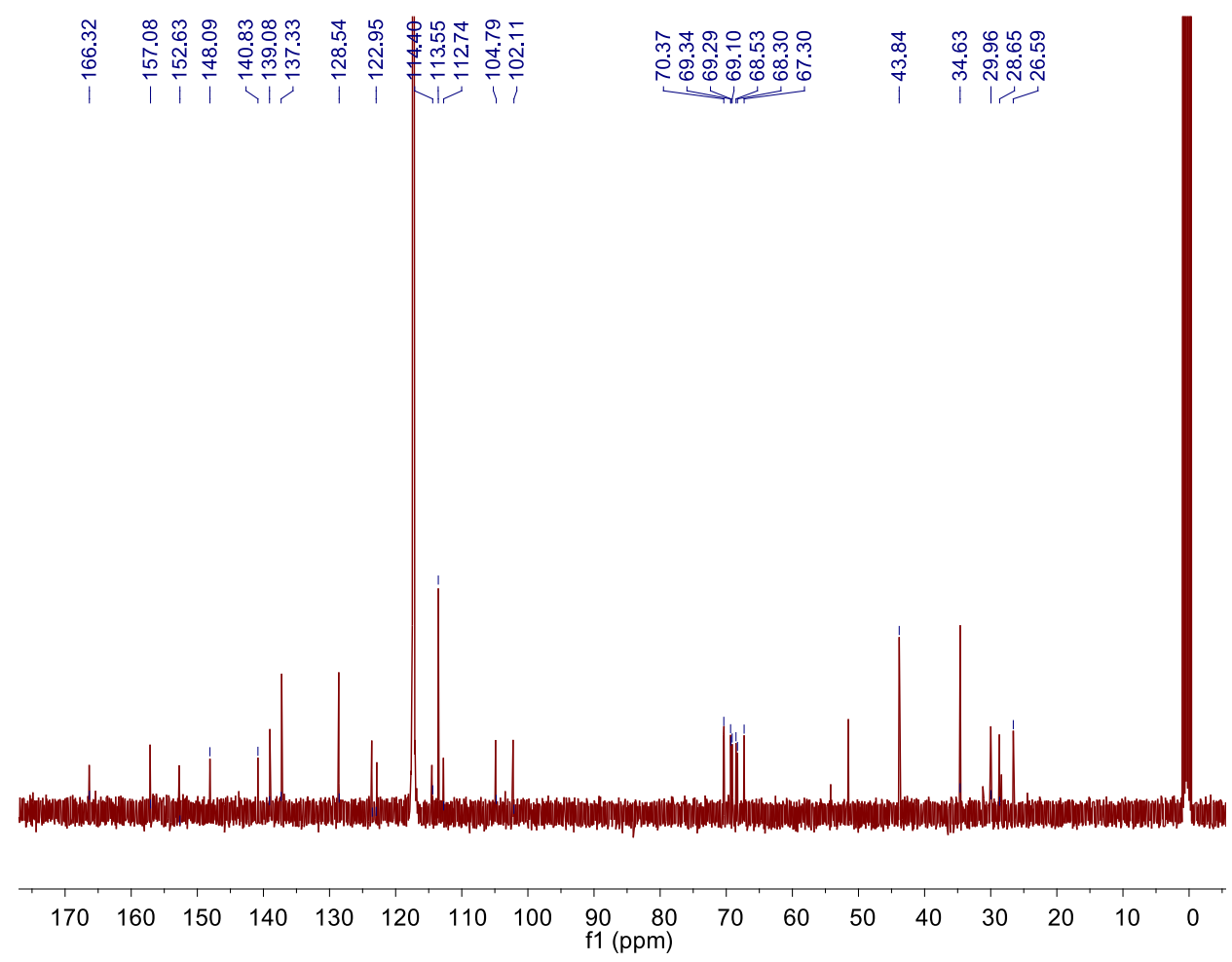

Figure S12. ${ }^{13} \mathrm{C}$ NMR spectrum (400 MHz, $\mathrm{CD}_{3} \mathrm{CN}, 298 \mathrm{~K}$ ) of compound $\mathbf{H 2}$.

Target Compound Screening Report

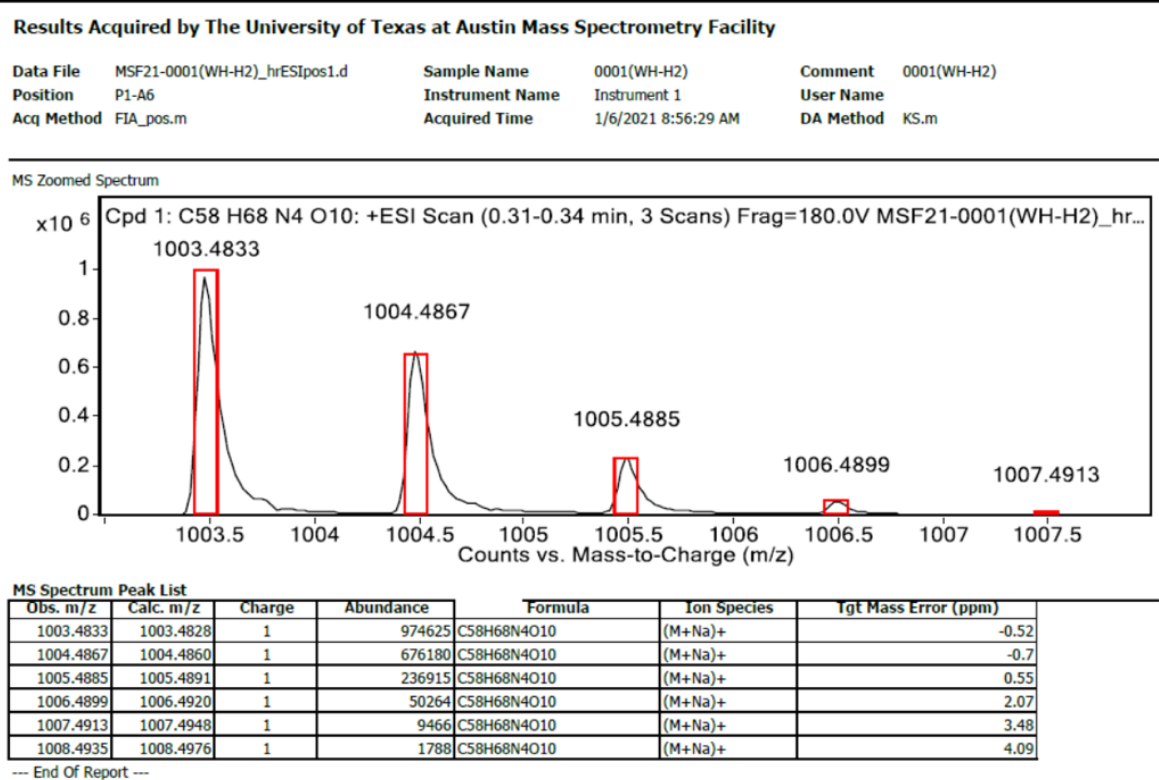

Figure S13. HR-ESI mass spectrum of compound $\mathbf{H 2}$. 


\subsection{Synthesis of H1-monomer}
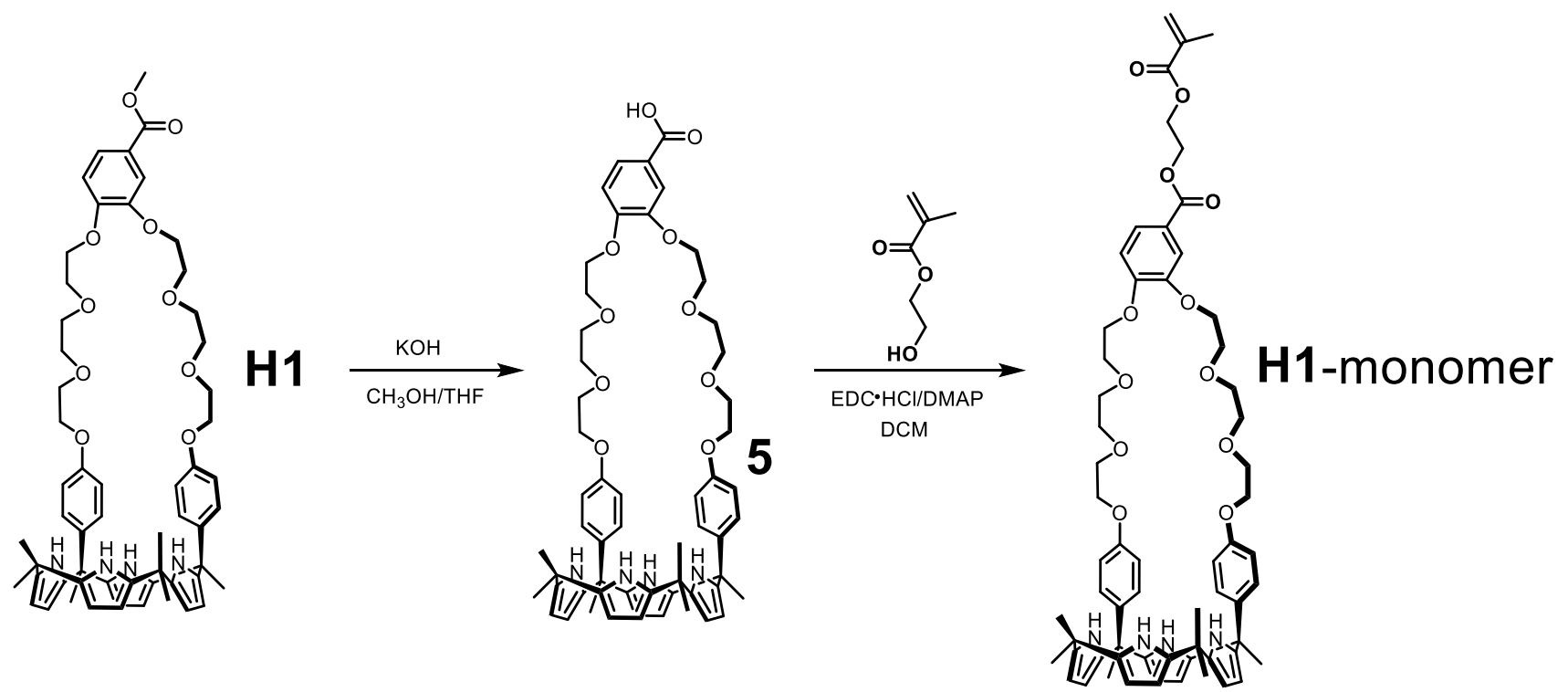

In a $500 \mathrm{~mL}$ round-bottomed flask equipped with a condenser and magnetic stirrer, compound $\mathbf{H 1}$ (1.00 g, $1.02 \mathrm{mmol})$ and $\mathrm{KOH}(1.12 \mathrm{~g}, 20.0 \mathrm{mmol})$ were added to $100 \mathrm{~mL}$ of a mixed solvent consisting of methanol/tetrahydrofuran $(1: 1)$. The resulting mixture was stirred for 24 hours. When the reaction was deemed complete by TLC analysis, $\mathrm{HCl}$ was added to adjust the solution to $\mathrm{pH}=1$. The volatiles were removed using a rotory evaporator. The mixture obtained in this way was dissolved in $200 \mathrm{ml}$ water, which was extracted with DCM (200 mL, 3x). The combined organic phase was dried over anhydrous $\mathrm{Na}_{2} \mathrm{SO}_{4}$ and concentrated under reduced pressure to give $\mathrm{t} 5$, which was used in the next step without further purification. A mixture of intermediate 5 (1.90 g), 2-hydroxyethyl methacrylate $(0.290 \mathrm{~g}$, $5.27 \mathrm{mmol})$, DMAP $(0.270 \mathrm{~g}, 2.19 \mathrm{mmol})$, and $\mathrm{EDC} \cdot \mathrm{HCl}(0.840 \mathrm{~g}, 4.39 \mathrm{mmol})$ in $200 \mathrm{~mL}$ of DCM was then stirred at room temperature for 1 day. The volatiles were removed using a rotory evaporator and the resulting residue was purified by silica gel flash column chromatography (DCM/methanol, 60:1 v/v, eluent) to provide H1-monomer as a white solid (1.30 g, 65\%). The ${ }^{1} \mathrm{H}$ NMR spectrum of compound H1-monomer is shown in Figure S14. ${ }^{1} \mathrm{H}$ NMR (400 MHz, DMSO- $\left.d_{6}, 298 \mathrm{~K}\right) \delta(\mathrm{ppm}): 10.17(\mathrm{~s}, 1 \mathrm{H}), 9.80(\mathrm{~s}, 1 \mathrm{H}), 8.94(\mathrm{~s}, 2 \mathrm{H}), 7.53(\mathrm{~s}, 1 \mathrm{H}), 7.42(\mathrm{~s}, 1 \mathrm{H}), 7.07$ (d, $8.4 \mathrm{~Hz}$, 1H), $6.84(\mathrm{~s}, 4 \mathrm{H}), 6.71(\mathrm{~d}, 8.8 \mathrm{~Hz}, 4 \mathrm{H}), 5.99(\mathrm{~s}, 1 \mathrm{H}), 5.83(\mathrm{~s}, 4 \mathrm{H}), 5.72(\mathrm{~s}, 2 \mathrm{H}), 5.64(\mathrm{~s}, 1 \mathrm{H}), 5.50(\mathrm{~d}, 19.0 \mathrm{~Hz}, 2 \mathrm{H})$, $4.42(\mathrm{~d}, 9.0 \mathrm{~Hz}, 4 \mathrm{H}), 4.06(\mathrm{~s}, 4 \mathrm{H}), 4.02(\mathrm{~s}, 4 \mathrm{H}), 3.75(\mathrm{~s}, 4 \mathrm{H}), 3.67$ (s, 4H), $3.62(\mathrm{~s}, 4 \mathrm{H}), 3.54(\mathrm{~s}, 4 \mathrm{H}), 1.82(\mathrm{~s}, 3 \mathrm{H})$, $1.68(\mathrm{~s}, 6 \mathrm{H}), 1.45(\mathrm{~s}, 6 \mathrm{H}), 1.32(\mathrm{~d}, 6.6 \mathrm{~Hz}, 6 \mathrm{H})$. The ${ }^{13} \mathrm{C}$ NMR spectrum of H1-monomer is shown in Figure $\mathrm{S} 15 .{ }^{13} \mathrm{C}$ NMR (400 MHz, DMSO- $d_{6}, 298$ K) $\delta$ (ppm): 157.1, 152.9, 148.2, 141.5, 139.8, 138.1, 136.3, 128.7, 125.3, 123.7, $114.1,113.5,105.1,103.7,103.4,103.2,102.2,70.5,69.2,68.8,67.4,43.8,35.1,30.3,29.2,28.9,27.5,17.4$. The HR ESI-MS trace for H1-monomer is shown in Fig. S16: m/z calcd for $[\mathrm{M}+\mathrm{Na}]^{+} \mathrm{C}_{63} \mathrm{H}_{74} \mathrm{~N}_{4} \mathrm{O}_{12}{ }^{+}, 1101.5195$; found 1101.5206; error -0.95 ppm. 


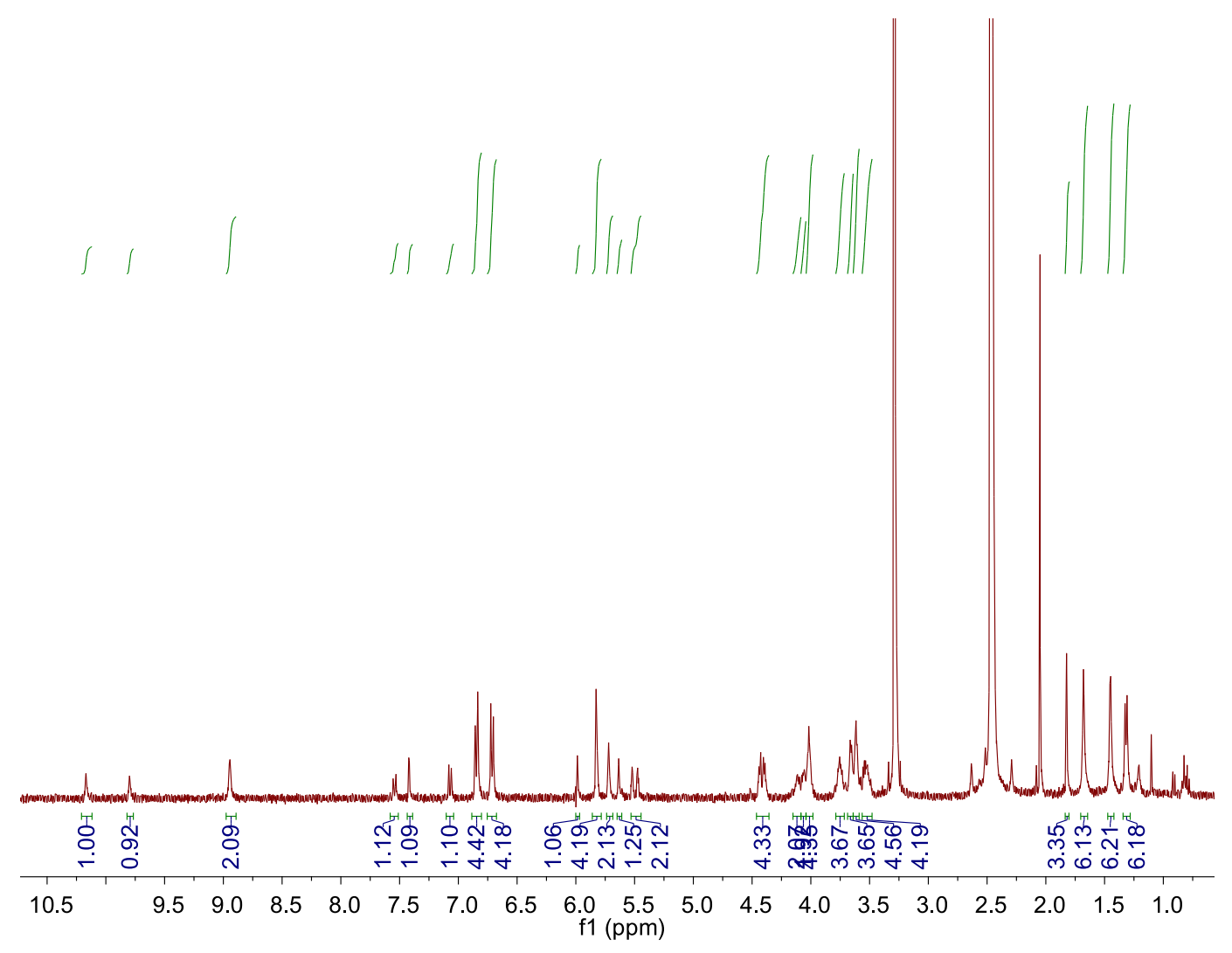

Figure S14. ${ }^{1} \mathrm{H}$ NMR spectrum (400 MHz, DMSO- $d_{6}, 298 \mathrm{~K}$ ) of H1-monomer.

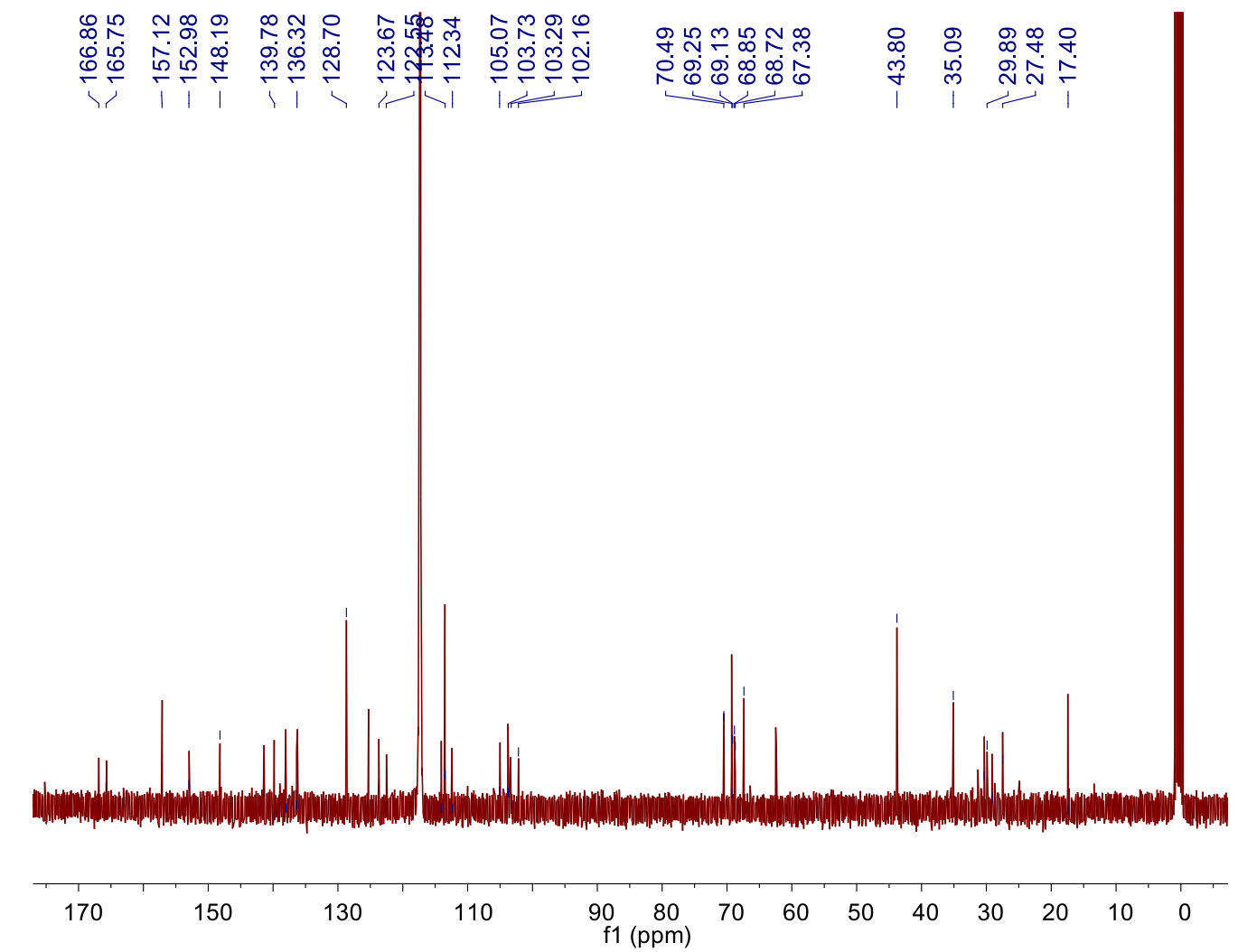

Figure S15. ${ }^{13} \mathrm{C}$ NMR spectrum (400 MHz, DMSO- $d_{6}, 298 \mathrm{~K}$ ) of H1-monomer. 
Target Compound Screening Report

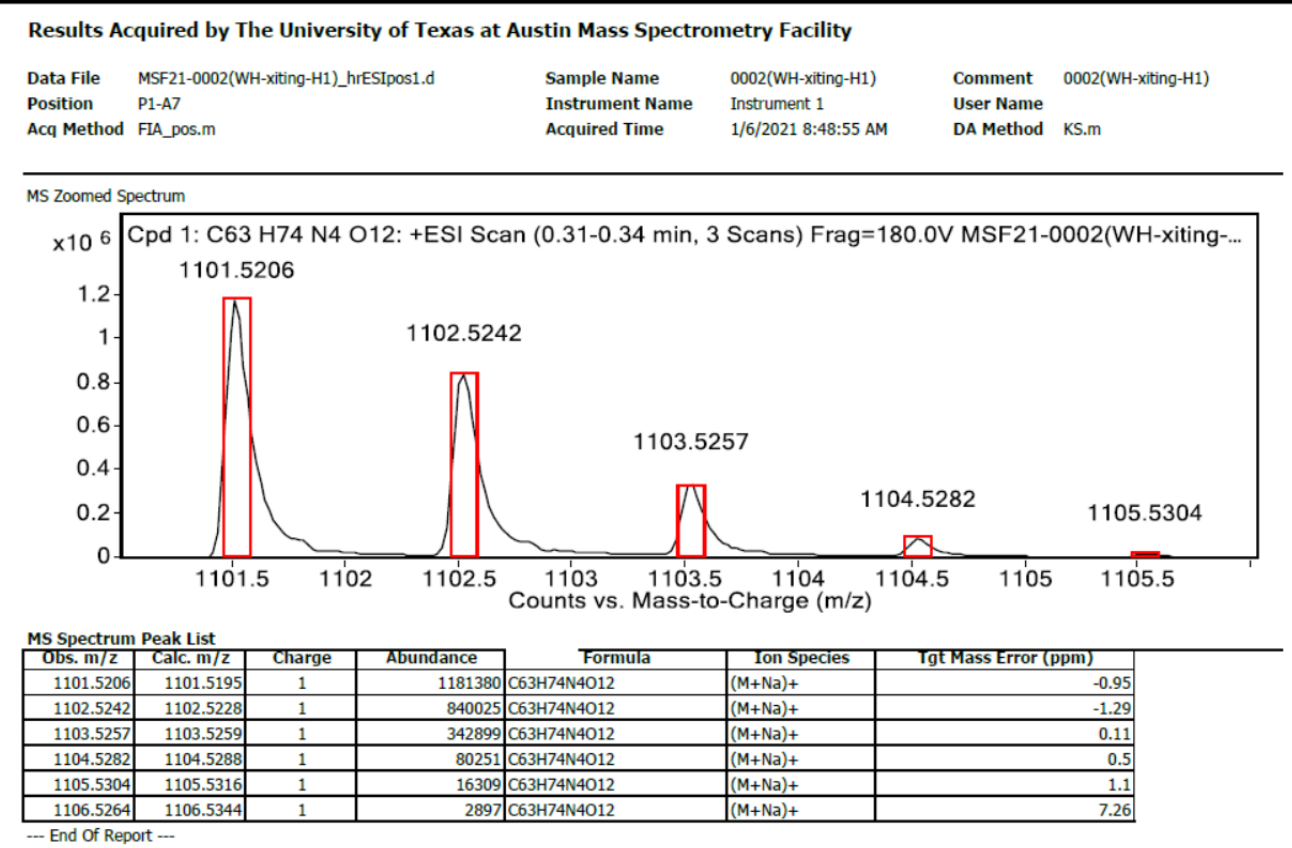

Figure S16. HR-ESI mass spectrum of H1-monomer.
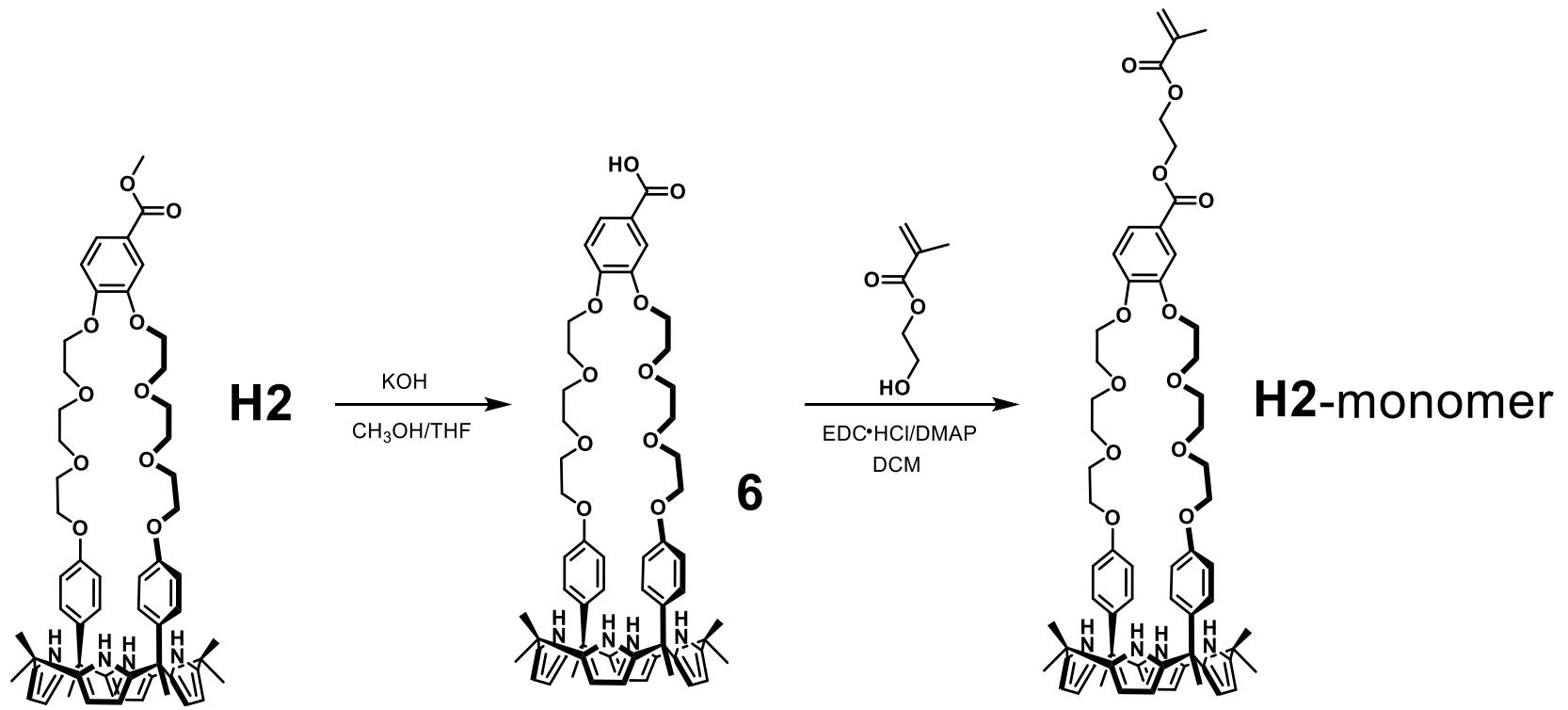

In a $500 \mathrm{~mL}$ round-bottomed flask equipped with a condenser and magnetic stirrer, compound $\mathbf{H 2}(1.00 \mathrm{~g}, 20.0$ $\mathrm{mmol}$ ), and $\mathrm{KOH}$ (7.36 g, $40.0 \mathrm{mmol}$ ) were added to $100 \mathrm{~mL}$ of mixed solvent consisting of methanol/tetrahydrofuran (1:1). The mixture was stirred for 24 hours. The volatiles were removed using a rotory evaporator to give the intermediate 6, which was used in the next step without further purification. A mixture of intermediate 6 (1.90 g, $4.39 \mathrm{mmol})$, 2-hydroxyethyl methacrylate $(0.290 \mathrm{~g}, 5.27 \mathrm{mmol})$, DMAP $(0.270 \mathrm{~g}, 2.19 \mathrm{mmol})$, and EDC $\cdot \mathrm{HCl}(0.840$ $\mathrm{g}, 4.39 \mathrm{mmol}$ ) in $200 \mathrm{~mL}$ of DCM was stirred at room temperature for 1 day. The volatiles were removed using a 
rotory evaporator and then the residue was purified by silica gel flash column chromatography (dichloromethane/methanol, 60:1 v/v, eluent) to provide $\mathbf{H 2}$-monomer as a white solid (1.30 g, 65\%). The ${ }^{1} \mathrm{H}$ NMR spectrum of compound H2-monomer is shown in Figure S17. ${ }^{1} \mathrm{H}$ NMR (400 MHz, DMSO- $d_{6}, 298 \mathrm{~K}$ ) $\delta$ (ppm): 9.45 (s, 4H), $7.53(\mathrm{~m}, 1 \mathrm{H}), 7.44$ (d, $2.0 \mathrm{~Hz}, 1 \mathrm{H}), 7.08$ (d, 1H), 6.79 (s, 4H), 6.67 (m, 4H), $6.01(\mathrm{~s}, 1 \mathrm{H}), 5.63$ (d, $2.8 \mathrm{~Hz}$, 8H), 5.59 (d, 2H), 4.48-4.44 (m, 2H), $4.42(\mathrm{~d}, \mathrm{~Hz}, 2 \mathrm{H}), 4.13-4.09$ (m, 2H), 4.04 (d, $5.0 \mathrm{~Hz}, 6 \mathrm{H}), 3.69$ (d, $10.6 \mathrm{~Hz}$, $8 \mathrm{H}), 3.55(\mathrm{~s}, 8 \mathrm{H}), 1.87-1.83(\mathrm{~m}, 3 \mathrm{H}), 1.71(\mathrm{~s}, 6 \mathrm{H}), 1.60(\mathrm{~s}, 6 \mathrm{H}), 1.40(\mathrm{~s}, 6 \mathrm{H})$. The ${ }^{13} \mathrm{C}$ NMR spectrum of $\mathbf{H 2}$-monomer is shown in Figure S18. ${ }^{13} \mathrm{C}$ NMR (400 MHz, DMSO- $\left.d_{6}, 298 \mathrm{~K}\right) \delta(\mathrm{ppm}): 165.7,165.5,157.2,138.9,137.2,128.6$, 114.5, 113.6, 112.8, 104.9, 102.3, 70.4, 69.4, 68.9, 68.4, 67.3, 62.5, 43.8, 34.6, 29.9, 28.4, 26.6, 17.5. HRESIMS of H2-monomer is shown in Fig. S19: $\mathrm{m} / \mathrm{z}$ calcd for $[\mathrm{M}+\mathrm{Na}]^{+} \mathrm{C}_{63} \mathrm{H}_{74} \mathrm{~N}_{4} \mathrm{O}_{12}{ }^{+}, 1101.5195$; found 1101.5204; error -0.75 ppm.

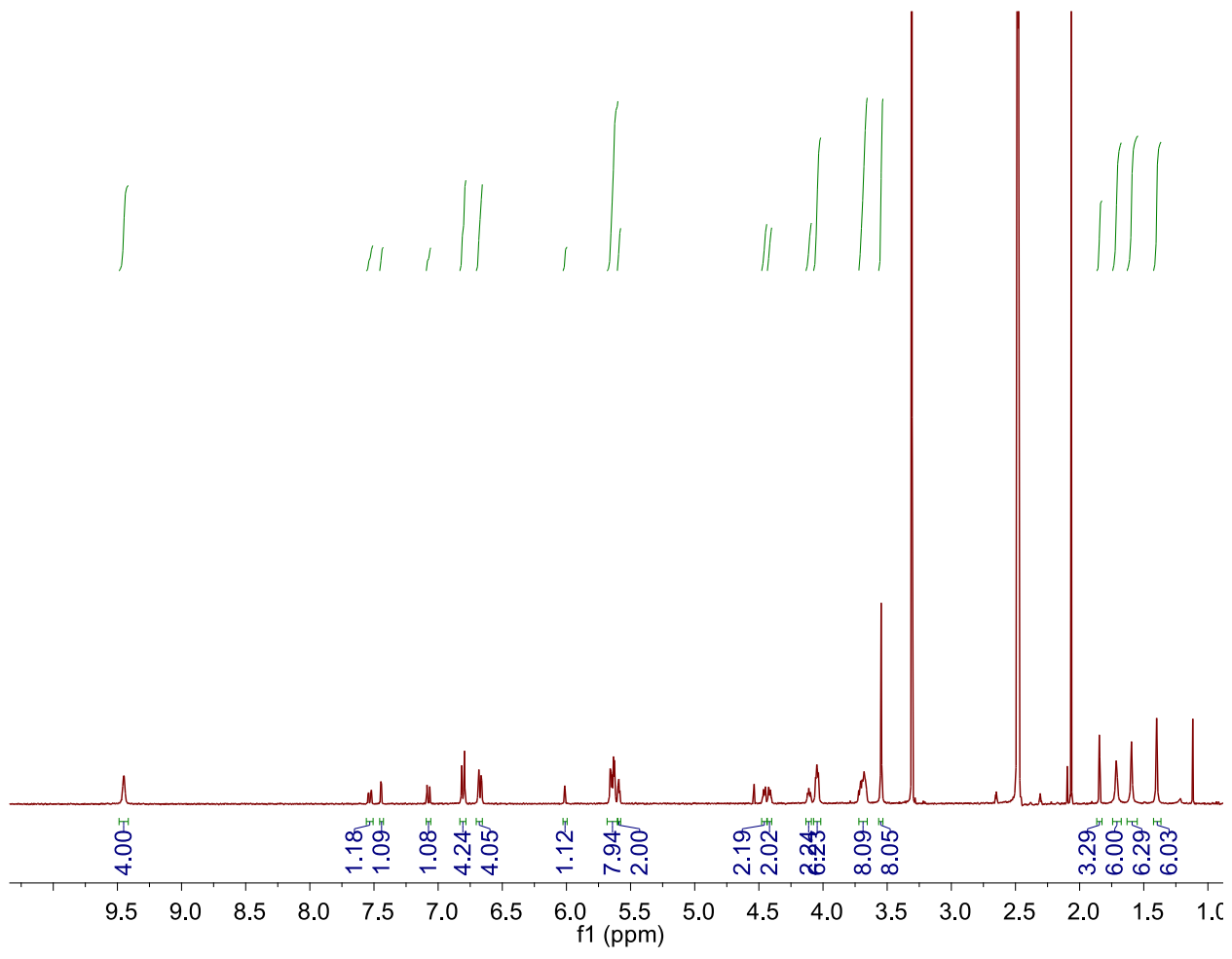

Figure S17. ${ }^{1} \mathrm{H}$ NMR spectrum (400 MHz, DMSO- $d_{6}, 298 \mathrm{~K}$ ) of $\mathbf{H 2}$-monomer. 


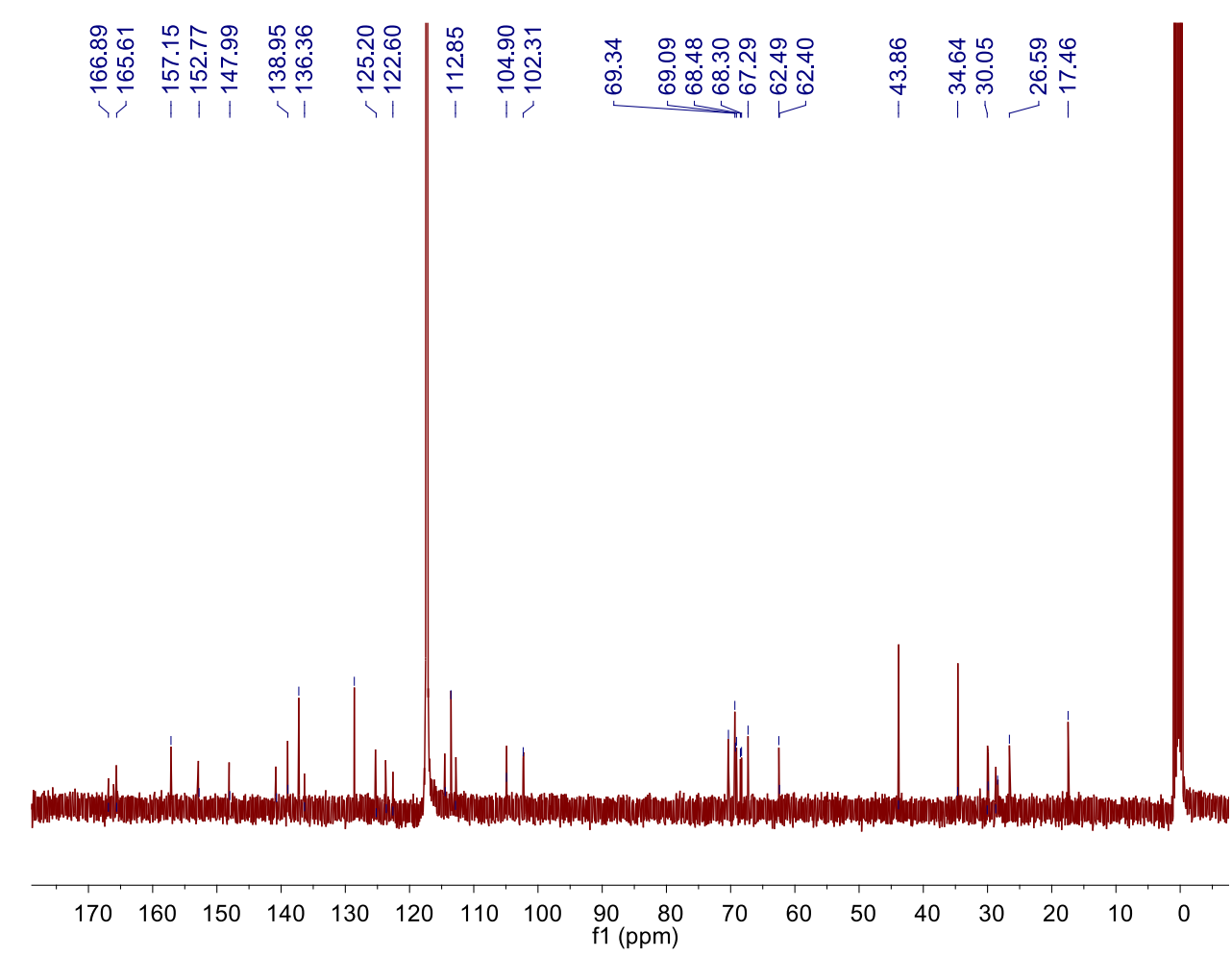

Figure S18. ${ }^{13} \mathrm{C}$ NMR spectrum $\left(400 \mathrm{MHz}\right.$, DMSO- $\left.d_{6}, 298 \mathrm{~K}\right)$ of H2-monomer.

Target Compound Screening Report

Results Acquired by The University of Texas at Austin Mass Spectrometry Facility

$\begin{array}{llllll}\text { Data File } & \text { MSF21-0003(WH-xiting-H2)_hrESIpos1.d } & \text { Sample Name } & 0003 \text { (WH-xiting-H2) } & \text { Comment } & \text { 0003(WH-xiting-H2) } \\ \text { Position } & \text { P1-A8 } & \text { Instrument Name } & \text { Instrument 1 } & \text { User Name } & \\ \text { Acq Method } & \text { FIA_pos.m } & \text { Acquired Time } & 1 / 6 / 20218: 58: 09 \text { AM } & \text { DA Method } & \text { KS.m }\end{array}$

MS Zoomed Spectrum

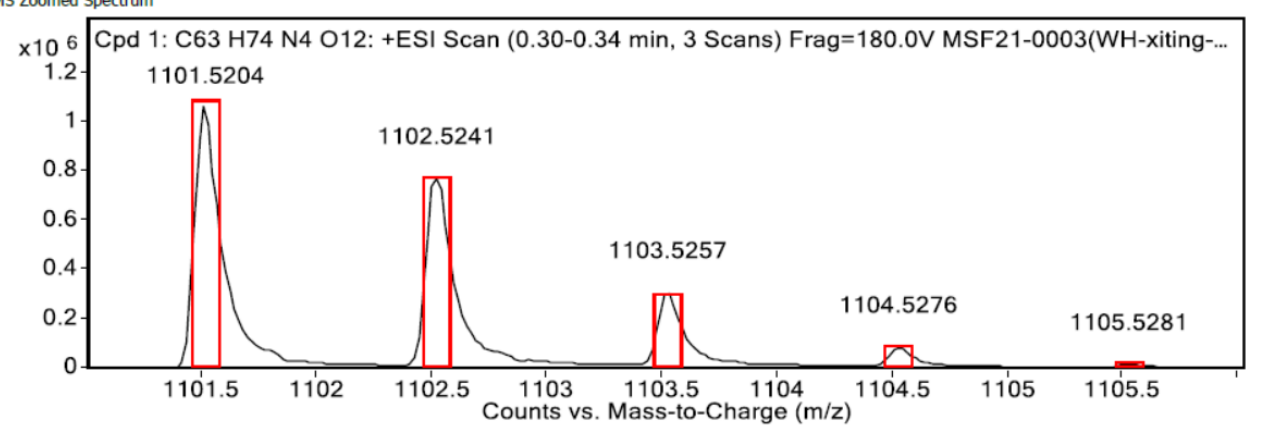

MS Spectrum Peak List
\begin{tabular}{|r|r|r|r|r|r|r|}
\hline Obs. m/z & Calc. m/z & Charge & Abundance & Formula & Ion Species & Tgt Mass Error (ppm) \\
\hline 1101.5204 & 1101.5195 & 1 & 1067163 & C63H744N4012 & $(\mathrm{M}+\mathrm{Na})+$ & -0.75 \\
\hline 1102.5241 & 1102.5228 & 1 & 772273 & $\mathrm{C} 63 \mathrm{H} 74 \mathrm{~N} 4012$ & $(\mathrm{M}+\mathrm{Na})+$ & -1.14 \\
\hline 1103.5257 & 1103.5259 & 1 & 307637 & $\mathrm{C} 63 \mathrm{H} 74 \mathrm{~N} 4012$ & $(\mathrm{M}+\mathrm{Na})+$ & 0.13 \\
\hline 1104.5276 & 1104.5288 & 1 & 85919 & $\mathrm{C} 63 \mathrm{H} 74 \mathrm{~N} 4012$ & $(\mathrm{M}+\mathrm{Na})+$ & 1.09 \\
\hline 1105.5281 & 1105.5316 & 1 & 14867 & $\mathrm{C} 63 \mathrm{H} 74 \mathrm{~N} 4012$ & $(\mathrm{M}+\mathrm{Na})+$ & 3.23 \\
\hline 1106.5255 & 1106.5344 & 1 & 3017 & $\mathrm{C} 63 \mathrm{H} 74 \mathrm{~N} 4012$ & $(\mathrm{M}+\mathrm{Na})+$ & 8.11 \\
\hline
\end{tabular}

Figure S19. HR-ESI mass spectrum of H2-monomer. 


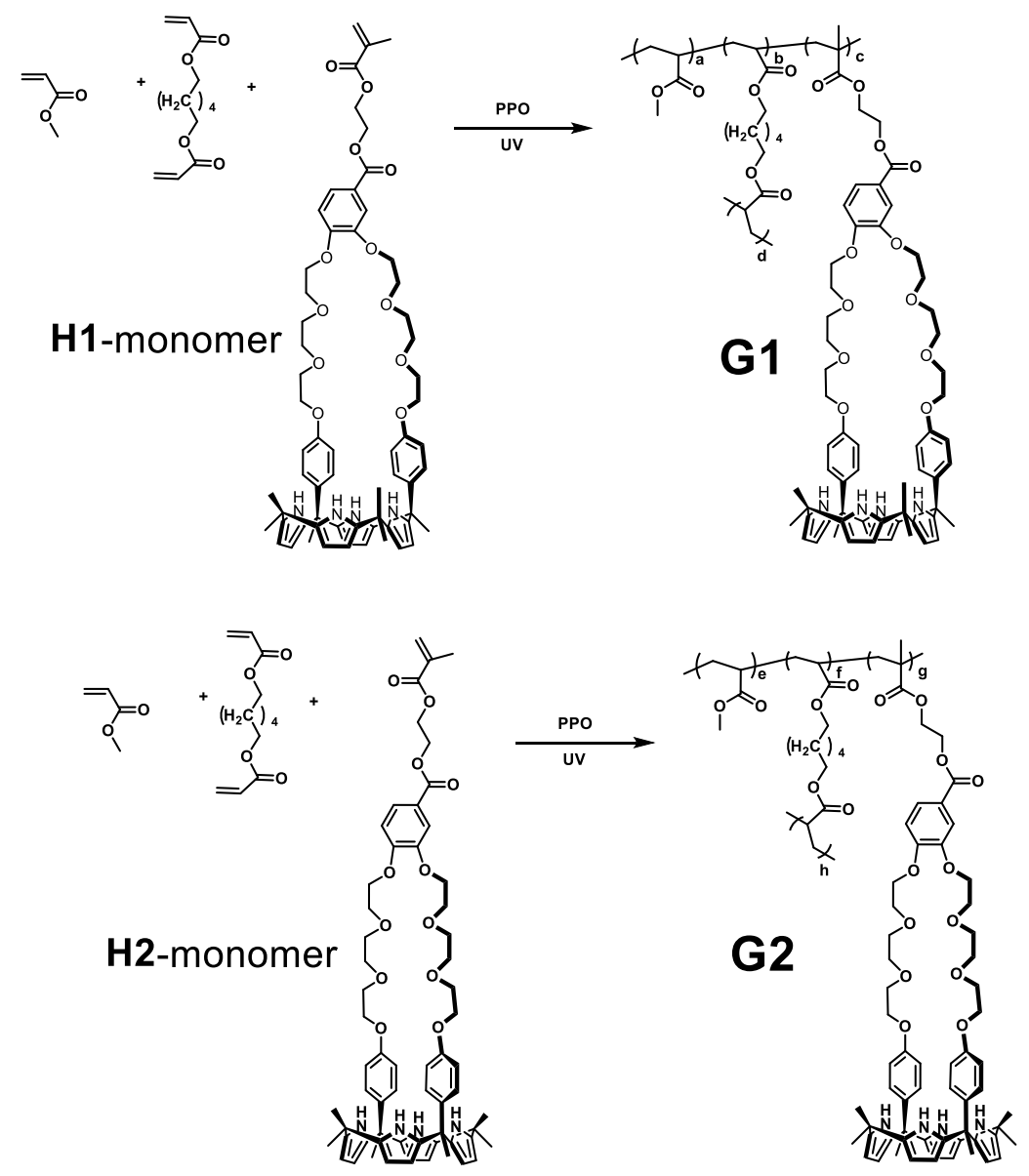

Figure S20. Preparation of organic gels G1 and G2.

H1-monomer or H2-monomer ( $536 \mathrm{mg}, 0.5 \mathrm{mmol}$ ), the chosen cross-linking agent (1,6-hexanediol diacrylate) (11.2 $\mathrm{mg}, \quad 0.05 \mathrm{mmol})$, methyl acrylate $(860 \mathrm{mg}, \quad 10 \mathrm{mmol})$, and the photoinitiator phenylbis $(2,4,6-$ trimethylbenzoyl)phosphine oxide $(41.8 \mathrm{mg}, 0.1 \mathrm{mmol})$ were dissolved in $5 \mathrm{ml}$ DMSO and stirred for $10 \mathrm{~min}$. This solution was injected into a reaction cell consisting of a pair of glass substrates separated by a $0.45 \mathrm{~cm}$ thick silicone rubber spacer, which was kept under $365 \mathrm{~nm}$ UV light for one hour to complete the polymerization and form the precursor form of the target organic gels. Soaking in acetonitrile for 3 days then provided organic gels G1 and G2. 

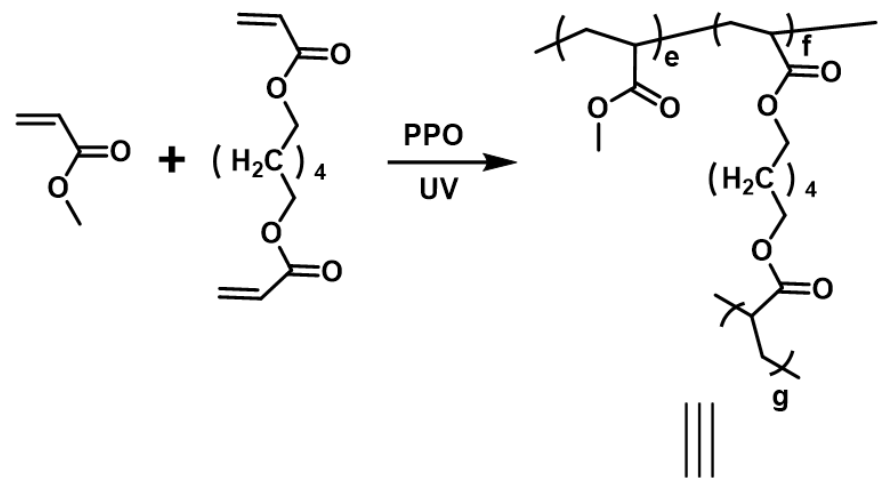

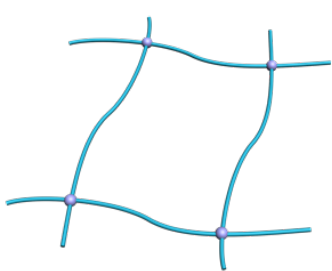

P-control
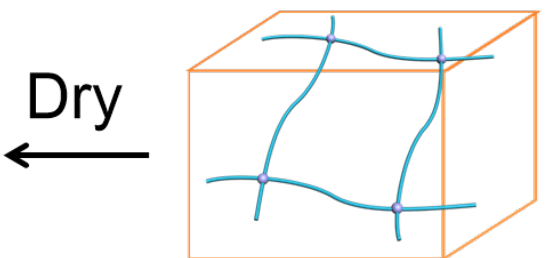

G-control

Figure S21. Preparation of G-control and P-control

The cross-linking agent (1,6-hexanediol diacrylate) (22.6 mg, $0.1 \mathrm{mmol})$, methyl acrylate $(1.72 \mathrm{~g}, 20 \mathrm{mmol})$, and the photoinitiator phenylbis(2,4,6-trimethylbenzoyl)phosphine oxide $(83.6 \mathrm{mg}, 0.2 \mathrm{mmol})$ were dissolved in $10 \mathrm{ml}$ DMSO and stirred for $10 \mathrm{~min}$. This solution was injected into a reaction cell consisting of a pair of glass substrates separated with $0.45 \mathrm{~cm}$ thick silicone rubber spacer, which was kept under $365 \mathrm{~nm}$ UV light for one hour to complete the polymerization and form an organic gel. This crude organic gel was soaked in acetonitrile for 3 days to give gel G-control. Removal of internal solvents present in G-control in vacuo at room temperature then gave the cross-linked networks P-control. 

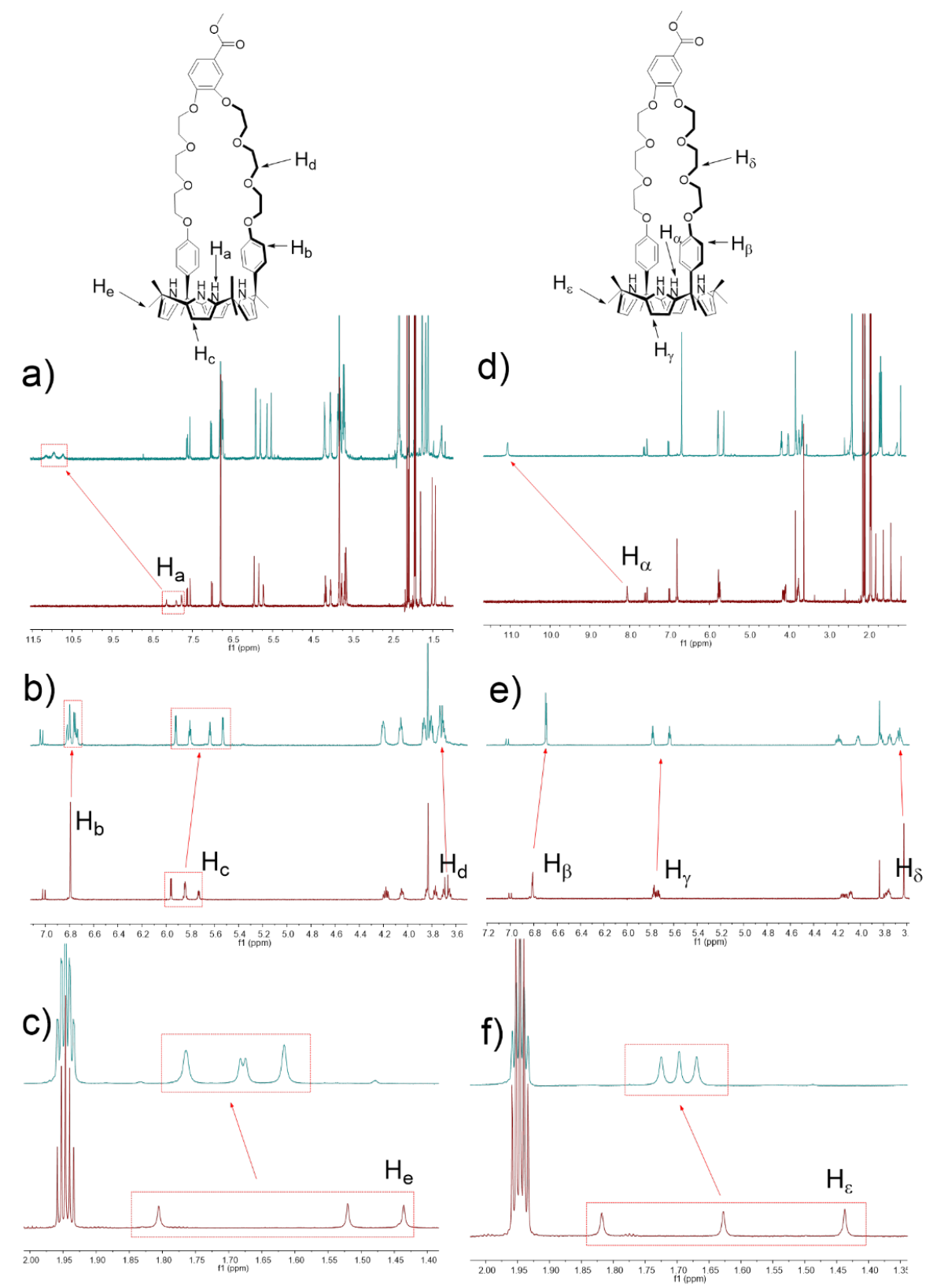

Figure S22. ${ }^{1} \mathrm{H}$ NMR spectra (400 MHz, $\mathrm{CD}_{3} \mathrm{CN}, 298 \mathrm{~K}$ ) of H1, H2, and their complexes (1:1) with LiCl. a) Full ${ }^{1} \mathrm{H}$ NMR spectra of $\mathbf{H 1}$ (bottom) and H1-LiCl complex (top); b) partial ${ }^{1} \mathrm{H}$ NMR spectra (3.6-7.0) of H1 (bottom) and H1-LiCl complex (up); c) partial ${ }^{1} \mathrm{H}$ NMR spectra (1.4-2.0) of H1 (bottom) and H1-LiCl complex (top); d) full ${ }^{1} \mathrm{H}$ NMR spectra of $\mathbf{H 2}$ (bottom) and $\mathbf{H 2}$-LiCl complex (top); b) partial ${ }^{1} \mathrm{H}$ NMR spectra (3.6-7.0) of $\mathbf{H 2}$ (bottom) and H2-LiCl complex (top); c) partial ${ }^{1} \mathrm{H}$ NMR spectra (1.4-2.0) of $\mathbf{H 2}$ (bottom) and $\mathbf{H 2}$-LiCl complex (top).

The host-guest interactions between $\mathbf{H 1}$ and $\mathbf{H 2}$ and $\mathrm{LiCl}$ in acetonitrile were probed by NMR spectroscopy as shown in Figure S22. In order to show more clearly the change in the chemical shift of each related proton, the full spectrum, a partial ${ }^{1} \mathrm{H}$ NMR spectrum (3.6-7.0), and a second partial ${ }^{1} \mathrm{H}$ NMR spectrum (1.4-2.0) are shown in Figure 3 of the main text. 
To determine the stoichiometry and association constant corresponding to the presumed interaction between $\mathbf{H 1}$ and H2 (Host) and test substrates (Guest), ${ }^{1} \mathrm{H}$ NMR spectroscopic titrations were carried out using solutions that had a constant concentration of Host $(5.00 \mathrm{mM})$ and varying concentrations of Guest. Using a non-linear curve-fitting method, the association constant corresponding to the interaction between guest Guest and Host was calculated. Why not a proof, a 1:1 stoichiometry was inferred on the basis of a mole ratio (Job) plot.

The non-linear curve-fitting was based on the following equation: ${ }^{[\mathrm{S} 4]}$

$\Delta \delta=\left(\Delta \delta_{\infty} /[\mathrm{G}]_{0}\right)\left(0.5[\mathrm{H}]_{0}+0.5\left([\mathrm{G}]_{0}+1 / K_{\mathrm{a}}\right)-\left(0.5\left([\mathrm{H}]_{0}^{2}+\left(2[\mathrm{H}]_{0}\left(1 / K_{\mathrm{a}}-[\mathrm{G}]_{0}\right)\right)+\left(1 / K_{\mathrm{a}}+[\mathrm{G}]_{0}\right)^{2}\right)^{0.5}\right)\right) \quad($ Eq. S1 $)$

Where $\Delta \delta$ is the chemical shift change of $\mathrm{H}_{\mathrm{f}} / \mathrm{H}_{\zeta}$ on Host at $[\mathrm{G}]_{0}, \Delta \delta_{\infty}$ is the chemical shift change of $\mathrm{H}_{\mathrm{f}} / \mathrm{H}_{\zeta}$ when the host is completely complexed, $[\mathrm{H}]_{0}$ is the fixed initial concentration of Host, and $[\mathrm{G}]_{0}$ is the varying concentration of Guest. 


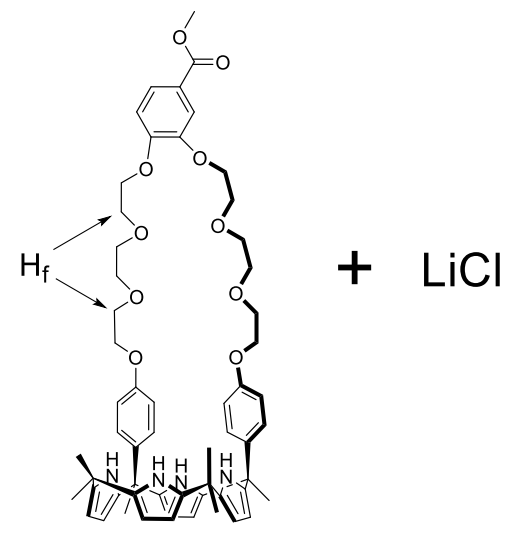

H1

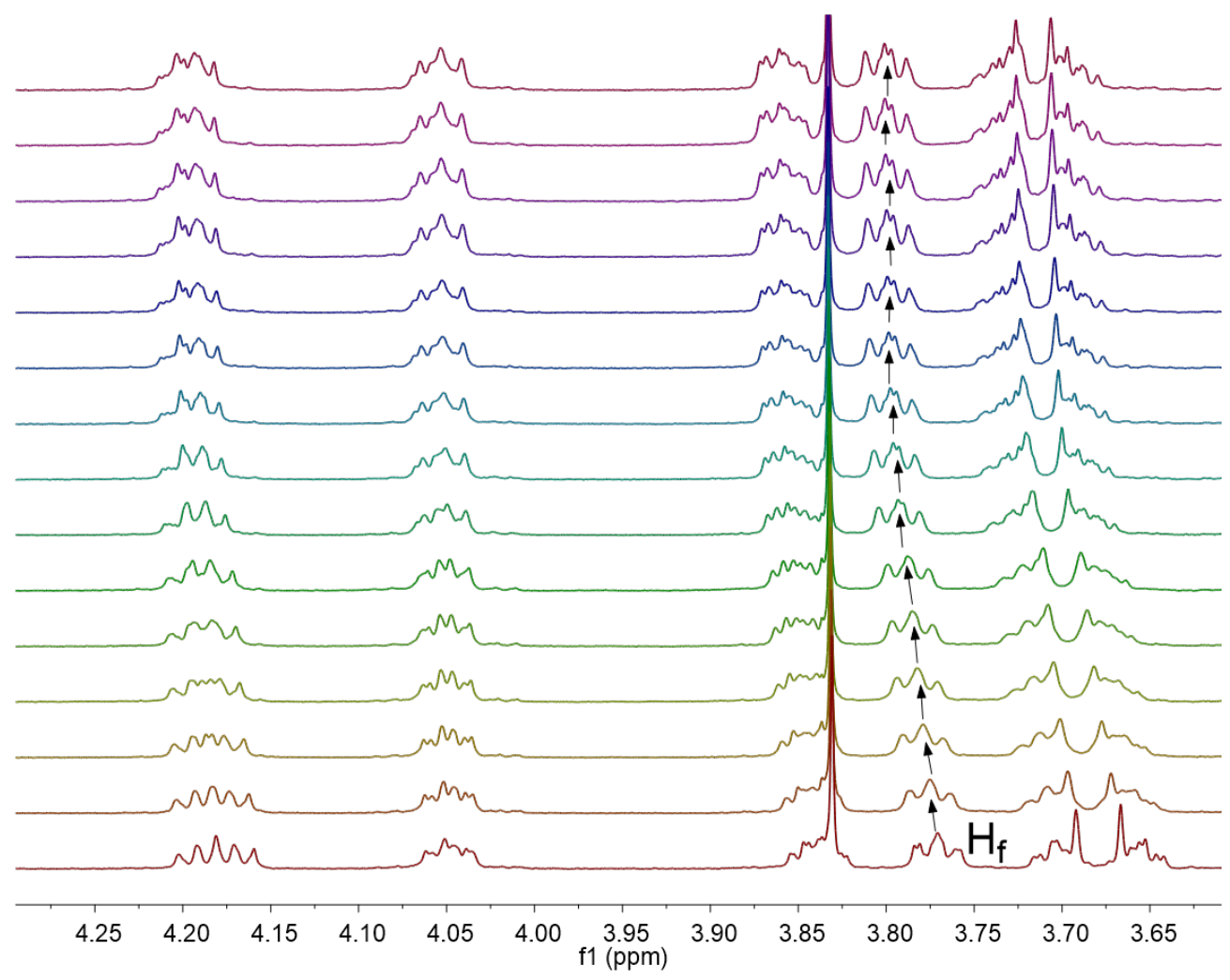

Figure S23. ${ }^{1} \mathrm{H}$ NMR spectra $\left(400 \mathrm{MHz}, \mathrm{CD}_{3} \mathrm{CN}, 298 \mathrm{~K}\right)$ of $\mathbf{H 1}$ (Host) recorded at a concentration of $5.00 \mathrm{mM}$ in the presence of different concentrations of $\mathrm{LiCl}$ (Guest): (a) $0.00 \mathrm{mM}$; (b) $1.18 \mathrm{mM}$; (c) $2.23 \mathrm{mM}$; (d) $3.18 \mathrm{mM}$; (e) $4.03 \mathrm{mM}$; (f) $4.8 \mathrm{mM}$; (g) $6.94 \mathrm{mM}$; (h) $8.58 \mathrm{mM}$; (i) $9.87 \mathrm{mM}$; (j) $10.91 \mathrm{mM}$; (k) $11.77 \mathrm{mM}$; (l) $12.5 \mathrm{mM}$; (m) 13.65 mM; (n) $14.52 \mathrm{mM}$; (o) $15.2 \mathrm{mM}$. 


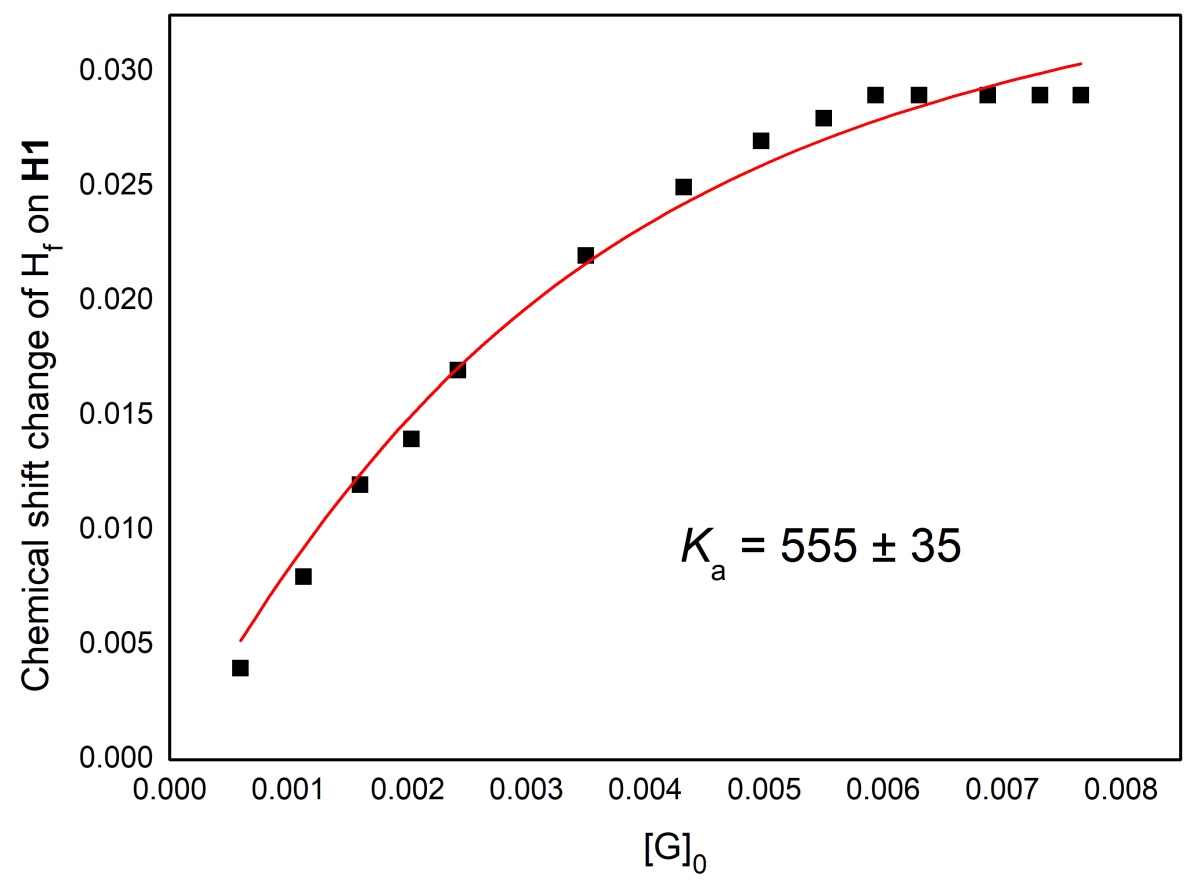

Figure S24. Changes in the chemical shift corresponding to $\mathrm{H}_{\mathrm{f}}$ on $\mathbf{H 1}$ (Host) as a function of added LiCl (Guest). The red solid line was obtained from a non-linear curve-fitting using Eq. S1. 


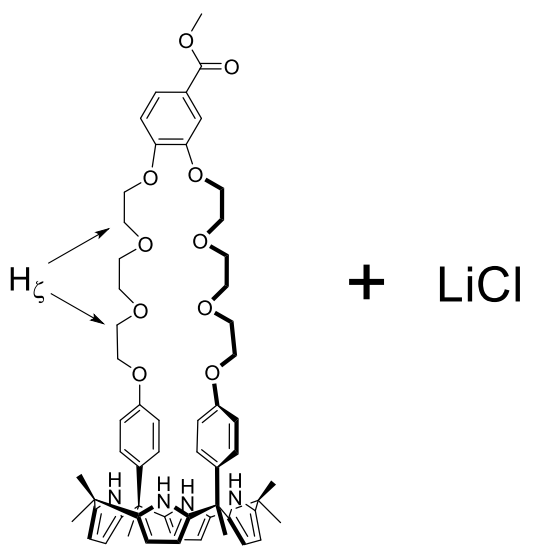

\section{$\mathrm{H} 2$}

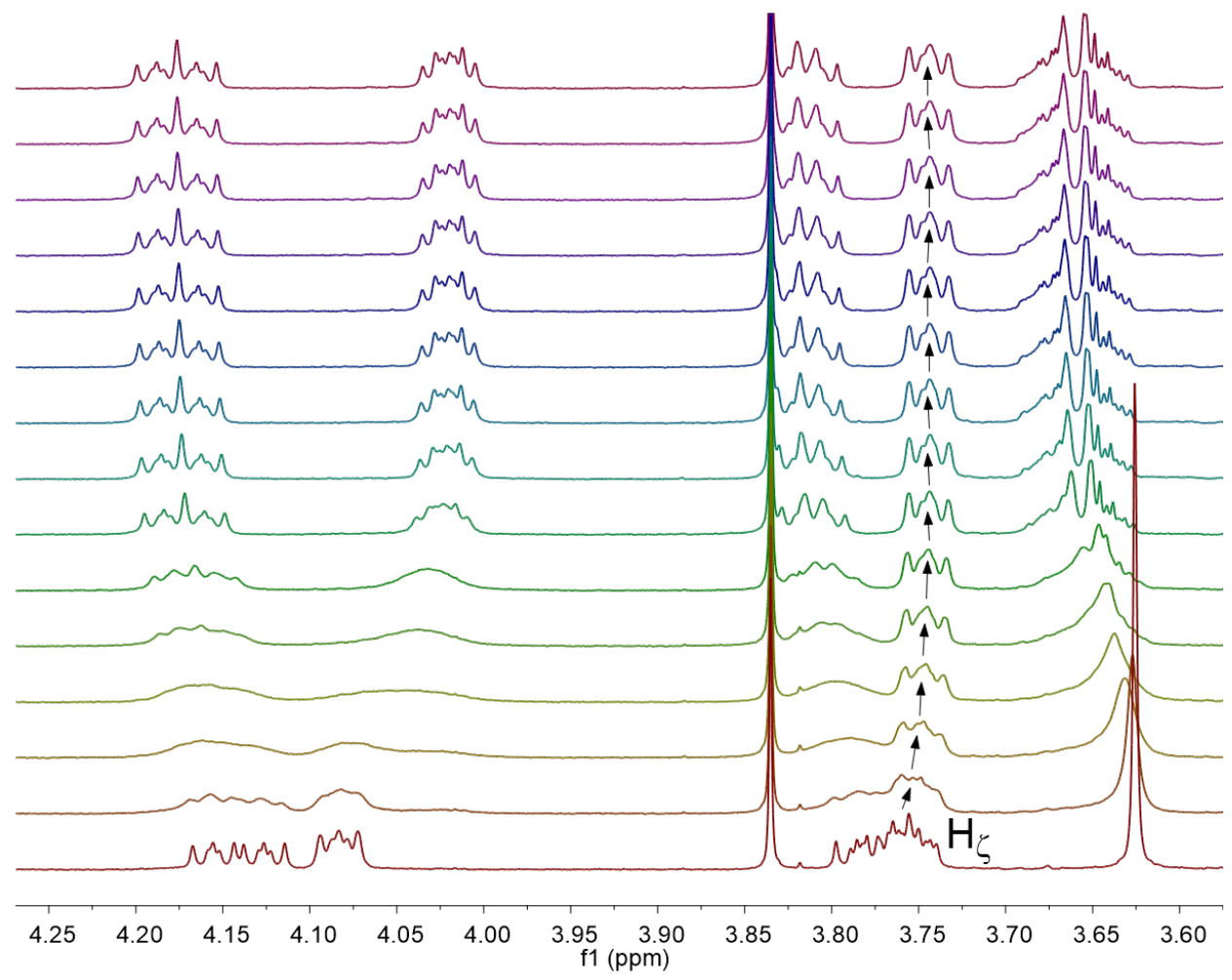

Figure S25. ${ }^{1} \mathrm{H}$ NMR spectra $\left(400 \mathrm{MHz}, \mathrm{CD}_{3} \mathrm{CN}, 298 \mathrm{~K}\right)$ of $\mathbf{H 2}$ (Host) recorded at a concentration of $5.00 \mathrm{mM}$ in the presence of different concentrations of $\mathrm{LiCl}$ (Guest): (a) $0.00 \mathrm{mM}$; (b) $1.18 \mathrm{mM}$; (c) $2.23 \mathrm{mM}$; (d) $3.18 \mathrm{mM}$; (e) $4.03 \mathrm{mM}$; (f) $4.8 \mathrm{mM}$; (g) $6.94 \mathrm{mM}$; (h) $8.58 \mathrm{mM}$; (i) $9.87 \mathrm{mM}$; (j) $10.91 \mathrm{mM}$; (k) $11.77 \mathrm{mM}$; (l) $12.5 \mathrm{mM}$; (m) 13.65 $\mathrm{mM}$; (n) $14.52 \mathrm{mM}$; (o) $15.2 \mathrm{mM}$. 


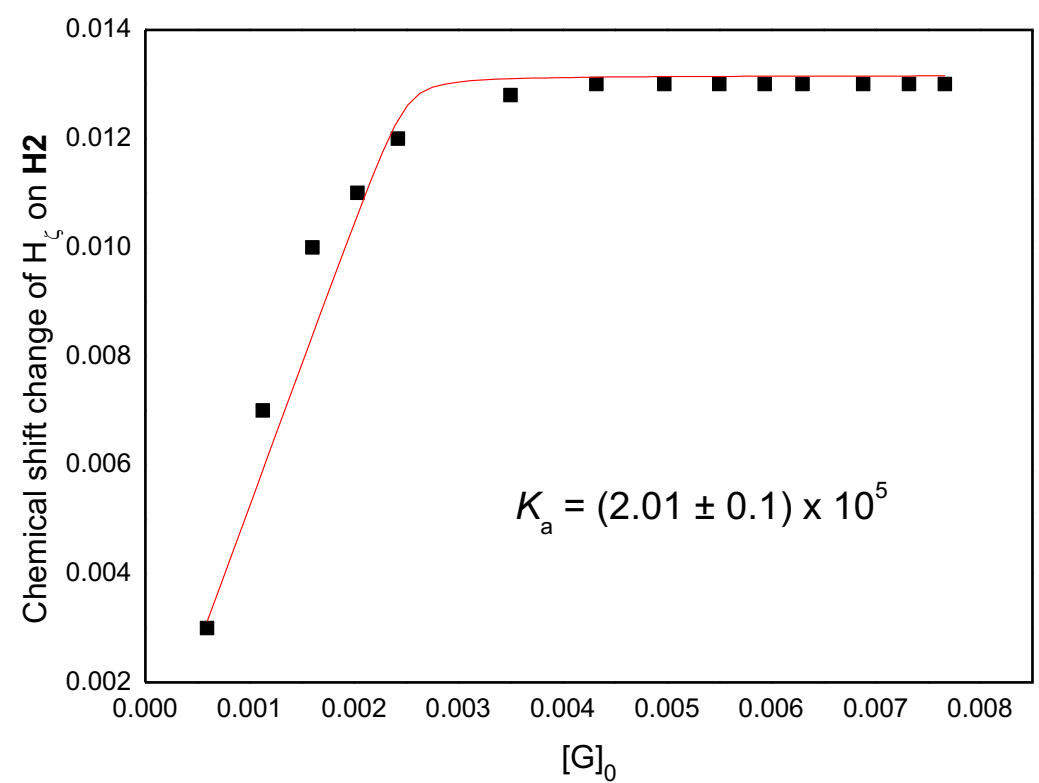

Figure S26. Changes in the chemical shift corresponding to $\mathrm{H}_{\zeta}$ on $\mathbf{H 2}$ (Host) as a function of added LiCl (Guest). The red solid line was obtained from a non-linear curve-fitting using Eq. S1. 
6. Interactions of $\mathbf{H 2 - m o n o m e r ~ i n ~ n i t r o t o l u e n e ~ o r ~} \mathbf{H 2}$ in acetonitrile with various salts ( $\mathrm{LiCl}, \mathrm{NaCl}, \mathrm{KCl}, \mathrm{MgCl}$, and $\mathrm{CaCl}_{2}$ alone and in combination)

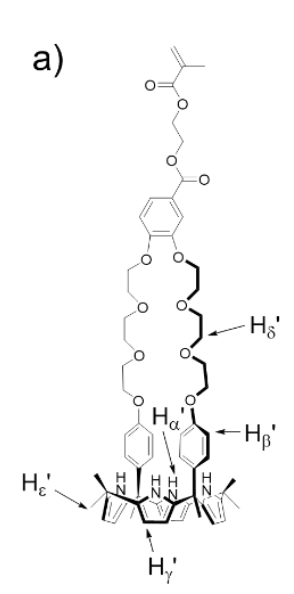

H2-monomer in nitrobenzene- $d_{5}$

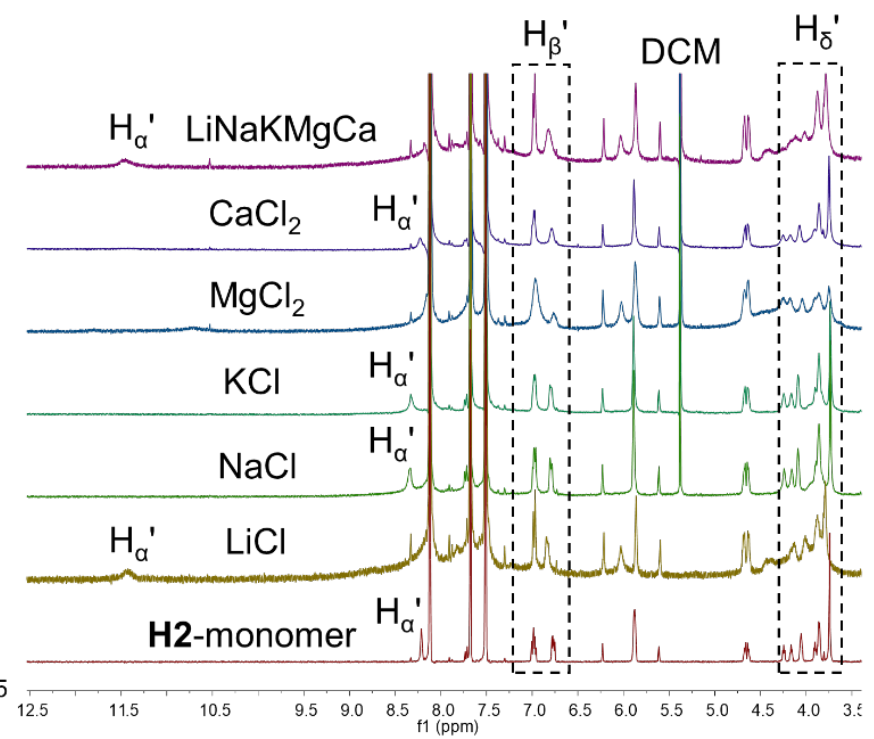

b)
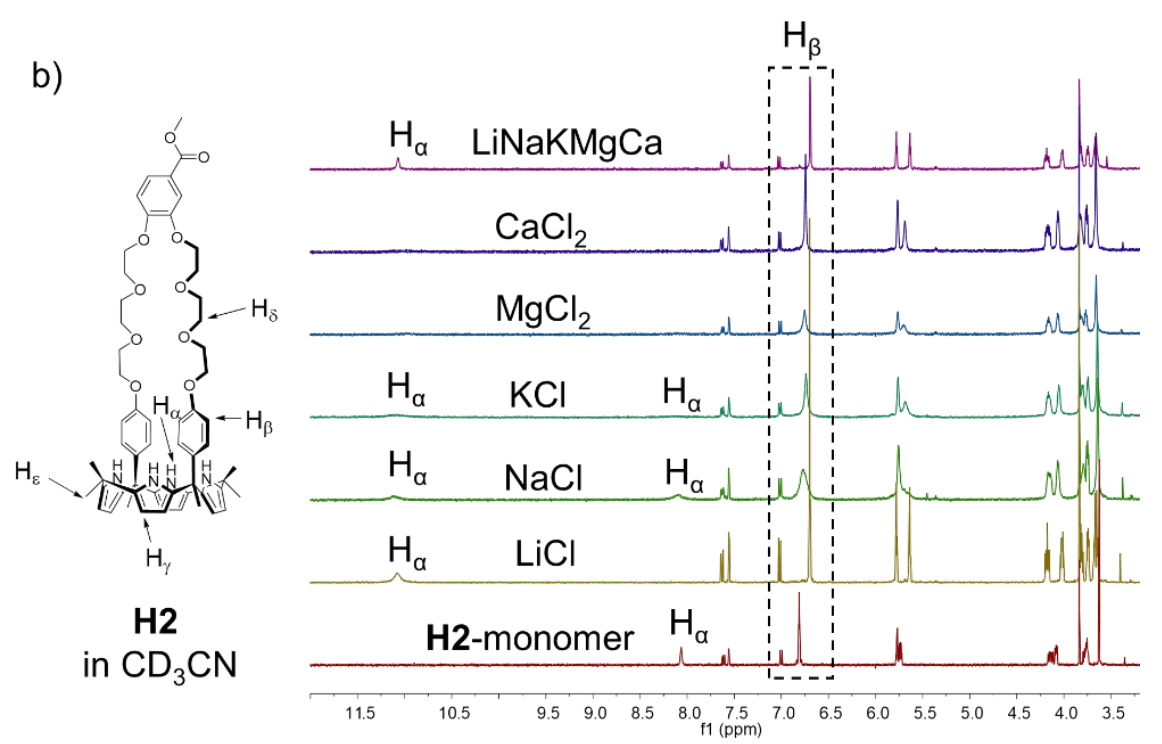

Figure S27. a) ${ }^{1} \mathrm{H}$ NMR spectra (400 MHz, nitrobenzene- $d_{5}, 298 \mathrm{~K}$ ) of $5.00 \mathrm{mM}$ solutions of $\mathbf{H 2}$-monomer made up in nitrobenzene- $d_{5}$ and contacted with $100 \mathrm{x}$ excess $\mathrm{LiCl}, \mathrm{NaCl}, \mathrm{KCl}, \mathrm{MgCl}_{2}$, and $\mathrm{CaCl}_{2}$ alone and in combination for one week; b) ${ }^{1} \mathrm{H}$ NMR spectra (400 MHz, $\mathrm{CD}_{3} \mathrm{CN}, 298 \mathrm{~K}$ ) of $5.00 \mathrm{mM}$ solutions of $\mathbf{H 2}$ made up in $\mathrm{CD}_{3} \mathrm{CN}$ and contacted with 100x excess $\mathrm{LiCl}, \mathrm{NaCl}, \mathrm{KCl}, \mathrm{MgCl}_{2}$, and $\mathrm{CaCl}_{2}$ alone and in combination for one week. 

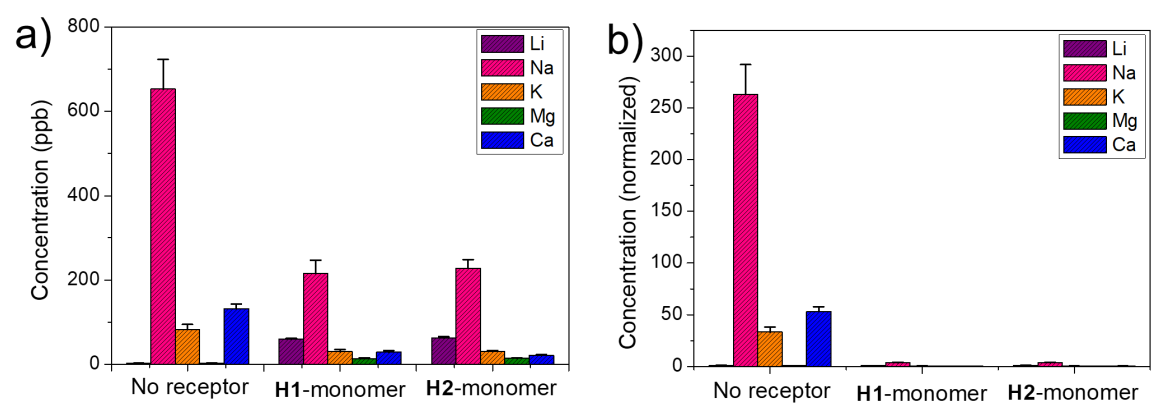

Figure S28. Solid-liquid extraction studies. a) Concentrations of $\mathrm{Li}, \mathrm{Na}, \mathrm{K}, \mathrm{Mg}$, and $\mathrm{Ca}$ in initially saturated mixed solutions of excess solid five salts ( $\mathrm{LiCl}, \mathrm{NaCl}, \mathrm{KCl}, \mathrm{MgCl}_{2}$, and $\mathrm{CaCl}_{2}$ ) in nitrobenzene before and after adding 10.0 mM H1-monomer or H2-monomer; b) data from the experiment in a) normalized to the Li concentration.

ICP-MS quantification studies in nitrobenzene: $0.1 \mathrm{ml}$ of solutions of $2 \mathrm{mg} \mathbf{H 1}$-monomer or $\mathbf{H 2}$-monomer in nitrobenzene were layered over a mixture of excess solid five salts ( $\mathrm{LiCl}, \mathrm{NaCl}, \mathrm{KCl}, \mathrm{MgCl}_{2}$, and $\mathrm{CaCl}_{2}$ ) for $48 \mathrm{~h}$. Then, the solutions were passed through $450-\mathrm{nm}$ filters. At this juncture, $0.05 \mathrm{ml}$ aliquots of the resulting solutions were removed and placed into new vials. To these vials were added $0.1 \mathrm{~mL}$ of a $0.2 \mathrm{M}$ sulfuric acid. The vials were then shaken for $4 \mathrm{~min}$ and allowed to stand overnight. Then, $5 \mu 1$ samples of the aqueous phase were removed and diluted to $5 \mathrm{ml}$ with $2 \% \mathrm{HNO}_{3}$ prior to analysis by ICP-MS. Control experiments were carried out in parallel using the solvent alone. All experiments were carried out in duplicate.
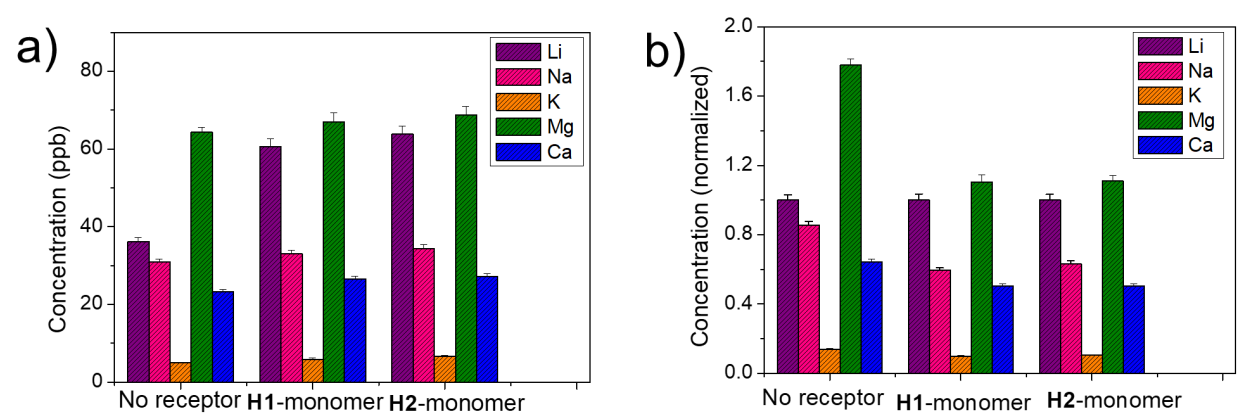

Figure S29. Solid-liquid extraction studies. a) Concentrations of $\mathrm{Li}, \mathrm{Na}, \mathrm{K}, \mathrm{Mg}$, and $\mathrm{Ca}$ in initially saturated mixed solutions of excess solid five salts $\left(\mathrm{LiCl}, \mathrm{NaCl}, \mathrm{KCl}, \mathrm{MgCl}_{2}\right.$, and $\left.\mathrm{CaCl}_{2}\right)$ in acetonitrile before and after adding $2 \mathrm{mg}$ $\mathbf{H 1}$ or $\mathbf{H} 2$ in $0.1 \mathrm{ml}$ acetonitrile; b) data from the experiment in a) normalized to the Li concentration.

ICP-MS quantification studies in acetonitrile: $0.1 \mathrm{ml}$ of solutions of $2 \mathrm{mg} \mathbf{H 1}$ or $\mathbf{H 2}$ in acetonitrile were layered over a mixture of excess solid five salts $\left(\mathrm{LiCl}, \mathrm{NaCl}, \mathrm{KCl}, \mathrm{MgCl}_{2}\right.$, and $\left.\mathrm{CaCl}_{2}\right)$ for $48 \mathrm{~h}$. Then, the solutions were passed through 450-nm filters. The solvent was removed under reduced pressure. Then $3 \mathrm{ml}$ concentrated sulfuric acid was added into the vials to dissolve all the solids. Then, $5 \mu$ solution were removed and diluted to $5 \mathrm{ml}$ with $2 \% \mathrm{HNO}_{3}$ prior to analysis by ICP-MS. Control experiments were carried out in parallel using the solvent alone. All experiments were carried out in duplicate. 
8. Interactions of $\mathbf{H 1}$ with $\mathrm{LiCl}, \mathrm{NaCl}, \mathrm{KCl}, \mathrm{MgCl}_{2}$ and $\mathrm{CaCl}_{2}$

8.1 Changes in the ${ }^{1} H$ NMR spectrum of $\boldsymbol{H} 1$ and LiCl over time

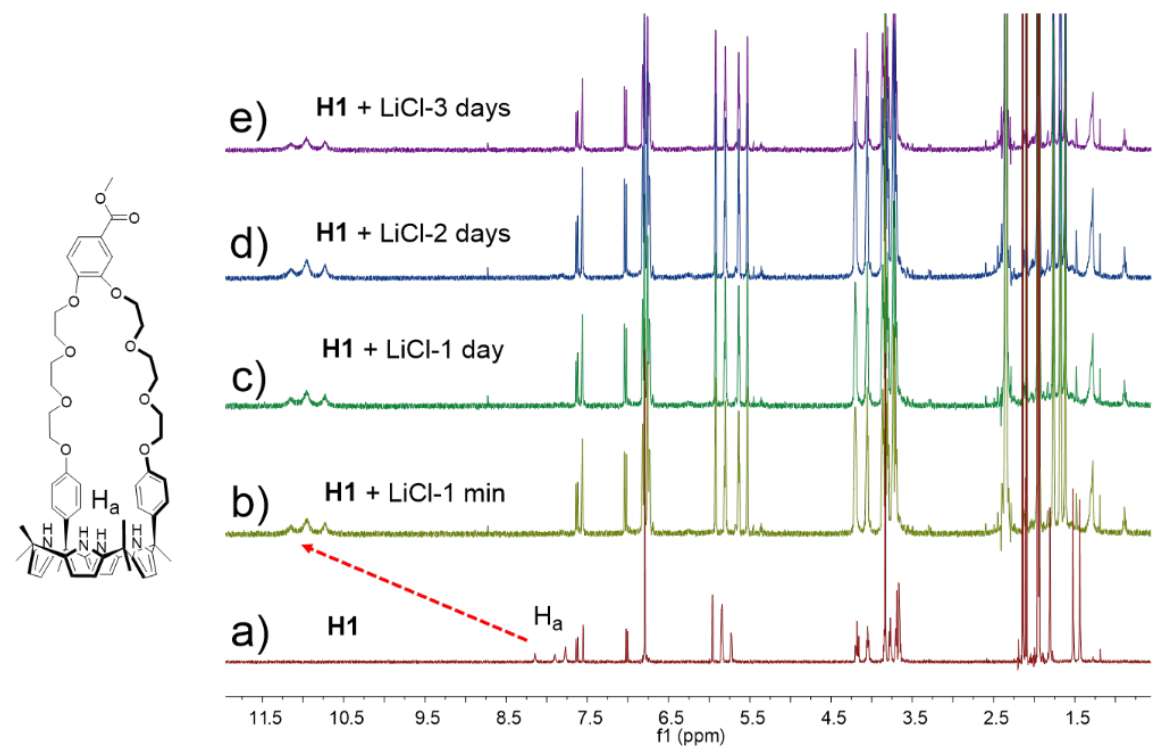

Figure S30. ${ }^{1} \mathrm{H}$ NMR spectra (400 MHz, $\mathrm{CD}_{3} \mathrm{CN}, 298 \mathrm{~K}$ ) of a) $5.00 \mathrm{mM} \mathrm{H1}$; b) $5.00 \mathrm{mM} \mathrm{H1}$ and 1 equiv of LiCl after mixing for $1 \mathrm{~min}$; c) $5.00 \mathrm{mM} \mathrm{H1}$ and 1 equiv of $\mathrm{LiCl}$ after mixing for 1 day; d) $5.00 \mathrm{mM} \mathrm{H1}$ and 1 equiv of $\mathrm{LiCl}$ after mixing for 2 days; e) $5.00 \mathrm{mM} \mathrm{H1}$ and 1 equiv of $\mathrm{LiCl}$ after mixing for 3 days.

\subsection{Competition between $\mathrm{H} \mathbf{} \supset \mathrm{LiCl}$ and $\mathrm{H} \mathbf{} \supset \mathrm{NaCl}$}
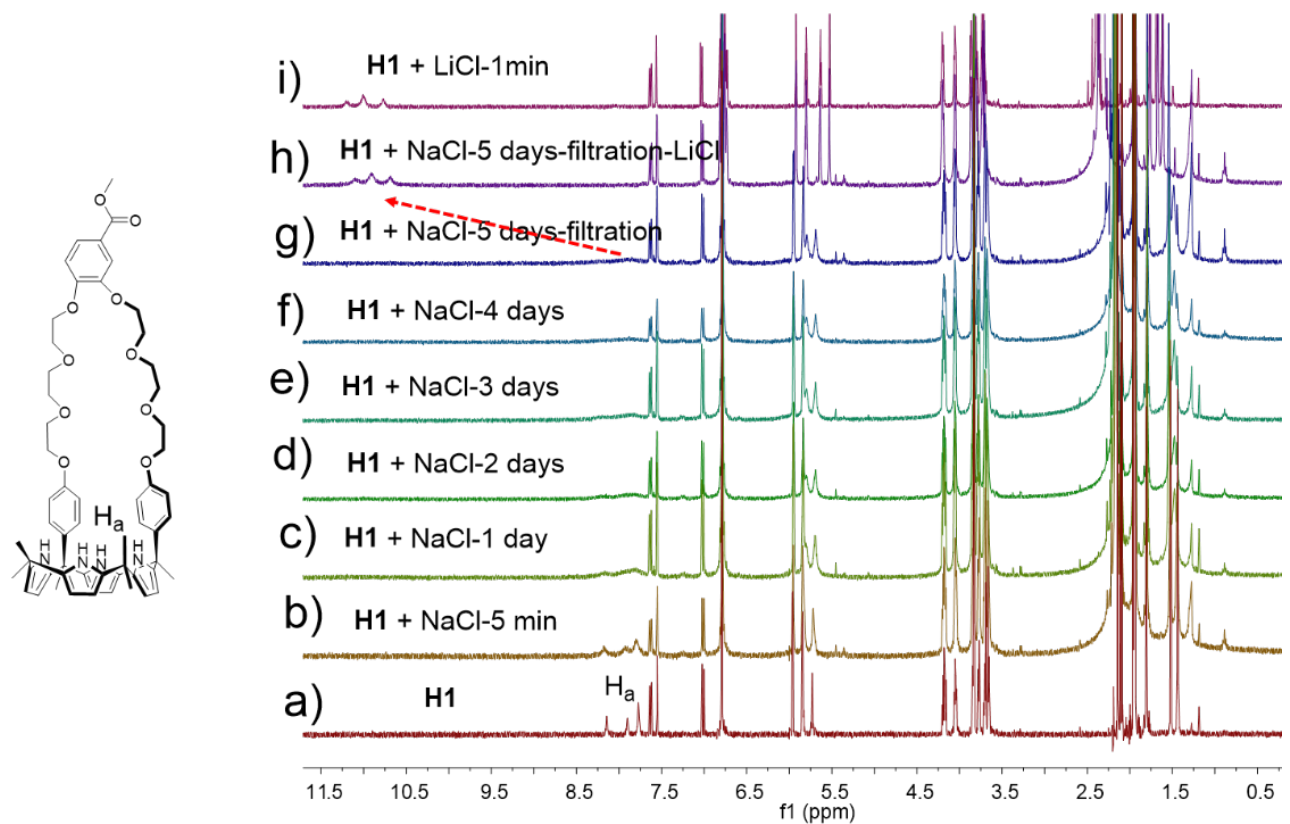

Figure S31. ${ }^{1} \mathrm{H}$ NMR spectra (400 MHz, $\mathrm{CD}_{3} \mathrm{CN}, 298 \mathrm{~K}$ ) of a) $5.00 \mathrm{mM}$ solution of $\mathbf{H 1}$; b) $5.00 \mathrm{mM}$ solution of $\mathbf{H 1}$ containing 1 equiv of $\mathrm{NaCl}$ after mixing for $1 \mathrm{~min}$; c) $5.00 \mathrm{mM}$ solution of $\mathbf{H 1}$ and 1 equiv of $\mathrm{NaCl}$ after mixing for 1 day; d) $5.00 \mathrm{mM}$ solution of $\mathbf{H 1}$ containing 1 equiv of $\mathrm{NaCl}$ after mixing for 2 days; e) $5.00 \mathrm{mM}$ solution of $\mathbf{H 1}$ and 1 equiv of $\mathrm{NaCl}$ after mixing for 3 days; f) $5.00 \mathrm{mM}$ solution of $\mathbf{H 1}$ and 1 equiv of $\mathrm{NaCl}$ after mixing for 4 days; g) filtered solution of $5.00 \mathrm{mM}$ solution of $\mathbf{H 1}$ and 1 equiv of $\mathrm{NaCl}$ after mixing for 5 days; h) spectrum from $\mathrm{g}$ ) after adding 1 equiv of $\mathrm{LiCl}$; i) $5.00 \mathrm{mM}$ solution of $\mathbf{H 1}$ and 1 equiv of $\mathrm{LiCl}$ after mixing for $1 \mathrm{~min}$. 


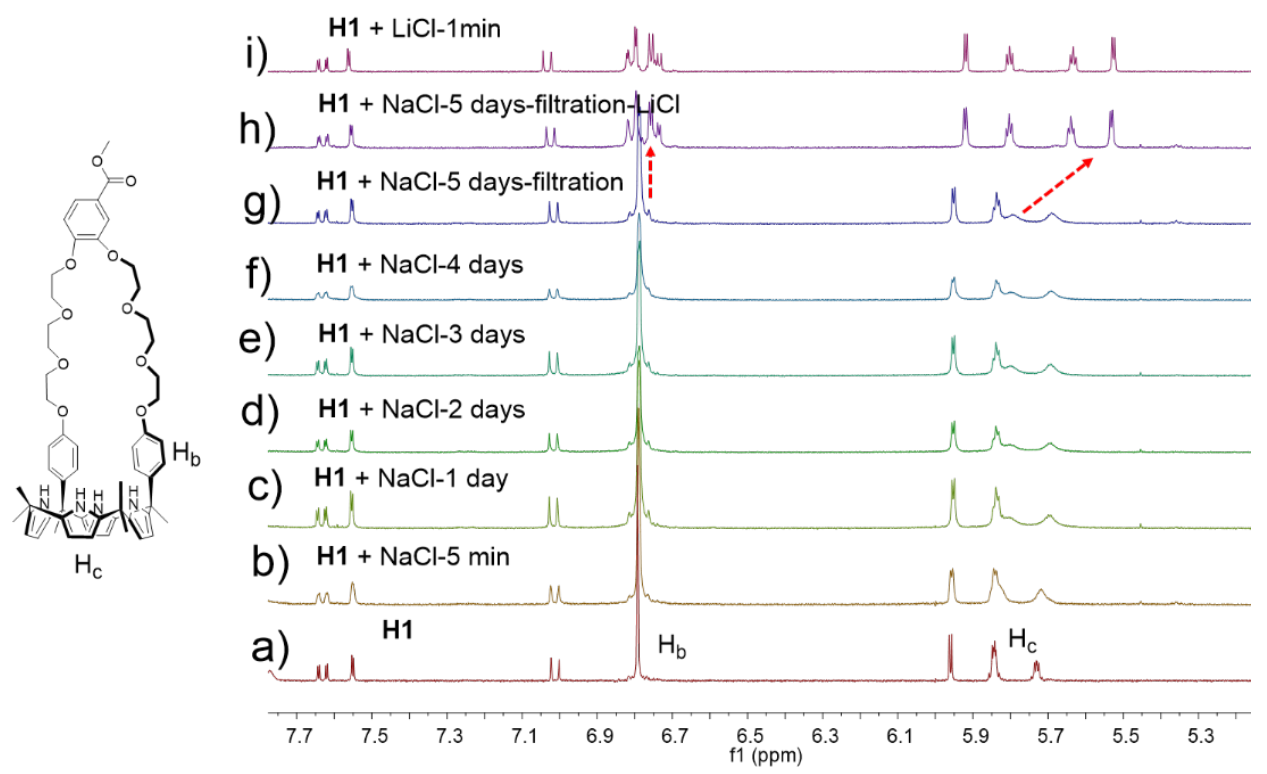

Figure S32. Partial ${ }^{1} \mathrm{H}$ NMR spectra (5.3-7.7) (400 MHz, $\mathrm{CD}_{3} \mathrm{CN}, 298 \mathrm{~K}$ ) of a) $5.00 \mathrm{mM}$ solution of H1; b) $5.00 \mathrm{mM}$ solution of $\mathbf{H 1}$ and 1 equiv of $\mathrm{NaCl}$ after mixing for $1 \mathrm{~min}$; c) $5.00 \mathrm{mM}$ solution of $\mathbf{H 1}$ and 1 equiv of $\mathrm{NaCl}$ after mixing for 1 day; d) $5.00 \mathrm{mM} \mathrm{H1}$ and 1 equiv of $\mathrm{NaCl}$ after mixing for 2 days; e) $5.00 \mathrm{mM}$ solution of $\mathbf{H 1}$ and 1 equiv of $\mathrm{NaCl}$ after mixing for 3 days; f) $5.00 \mathrm{mM} \mathrm{H1}$ and 1 equiv of $\mathrm{NaCl}$ after mixing for 4 days; g) filtered solution of $5.00 \mathrm{mM}$ solution of $\mathbf{H 1}$ and 1 equiv of $\mathrm{NaCl}$ after mixing for 5 days; h) experiment $\mathrm{g}$ ) after adding 1 equiv of $\mathrm{LiCl}$; i) $5.00 \mathrm{mM}$ solution of $\mathbf{H 1}$ and 1 equiv of $\mathrm{LiCl}$ after mixing for $1 \mathrm{~min}$.

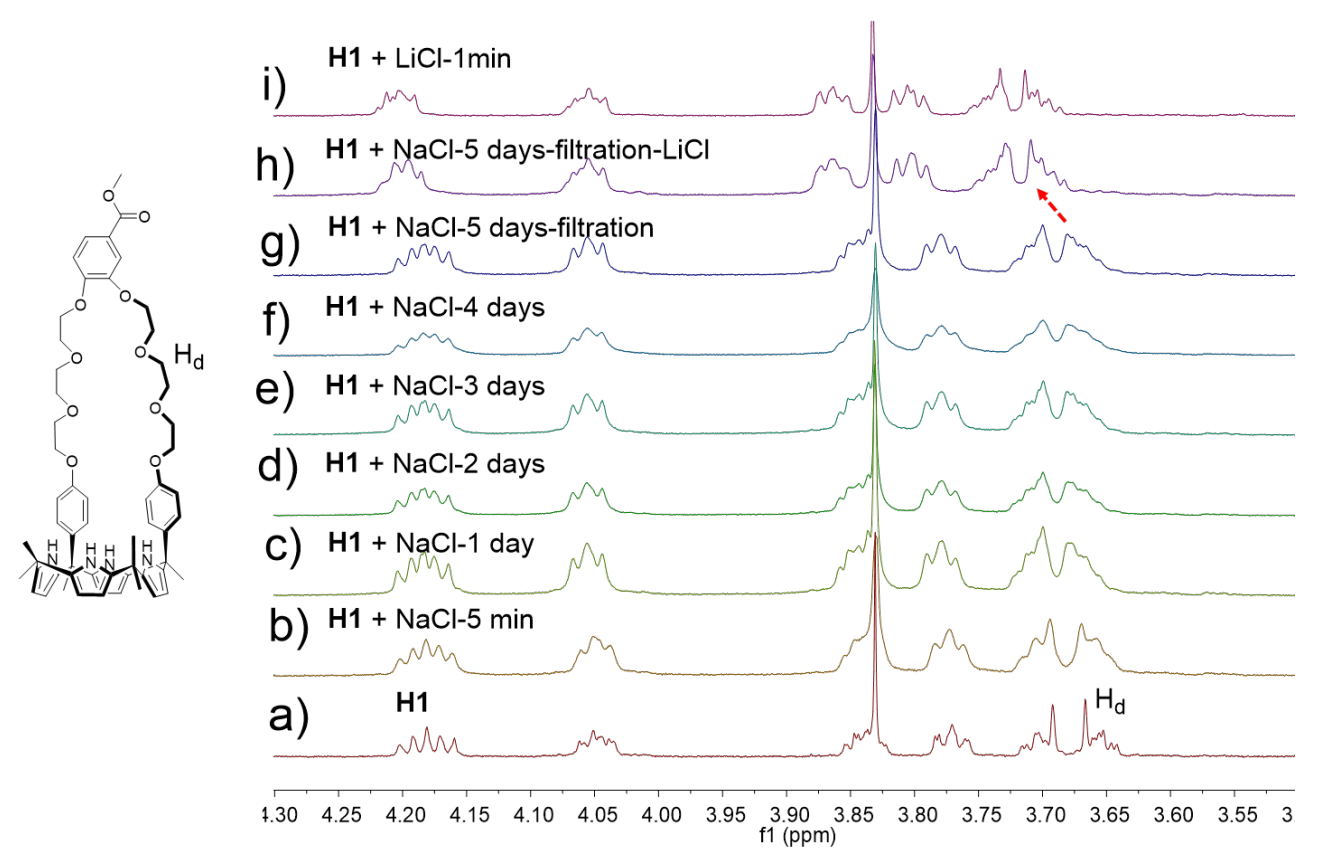

Figure S33. Partial ${ }^{1} \mathrm{H}$ NMR spectra (3.5-4.3) $\left(400 \mathrm{MHz}, \mathrm{CD}_{3} \mathrm{CN}, 298 \mathrm{~K}\right)$ of a) $5.00 \mathrm{mM}$ solution of H1; b) $5.00 \mathrm{mM}$ solution of $\mathbf{H 1}$ and 1 equiv of $\mathrm{NaCl}$ after mixing for $1 \mathrm{~min}$; c) $5.00 \mathrm{mM}$ solution of $\mathbf{H 1}$ and 1 equiv of $\mathrm{NaCl}$ after mixing for 1 day; d) $5.00 \mathrm{mM}$ solution of $\mathbf{H 1}$ and 1 equiv of $\mathrm{NaCl}$ after mixing for 2 days; e) $5.00 \mathrm{mM} \mathbf{H 1}$ and 1 equiv of $\mathrm{NaCl}$ after mixing for 3 days; f) $5.00 \mathrm{mM}$ solution of $\mathbf{H 1}$ and 1 equiv of $\mathrm{NaCl}$ after mixing for 4 days; $\mathrm{g}$ ) 
filtered solution of $5.00 \mathrm{mM}$ solution of $\mathbf{H 1}$ and 1 equiv of $\mathrm{NaCl}$ after mixing for 5 days; h) $\mathrm{g}$ after adding 1 equiv of $\mathrm{LiCl}$; i) $5.00 \mathrm{mM}$ solution of $\mathbf{H 1}$ and 1 equiv of $\mathrm{LiCl}$ after mixing for $1 \mathrm{~min}$.
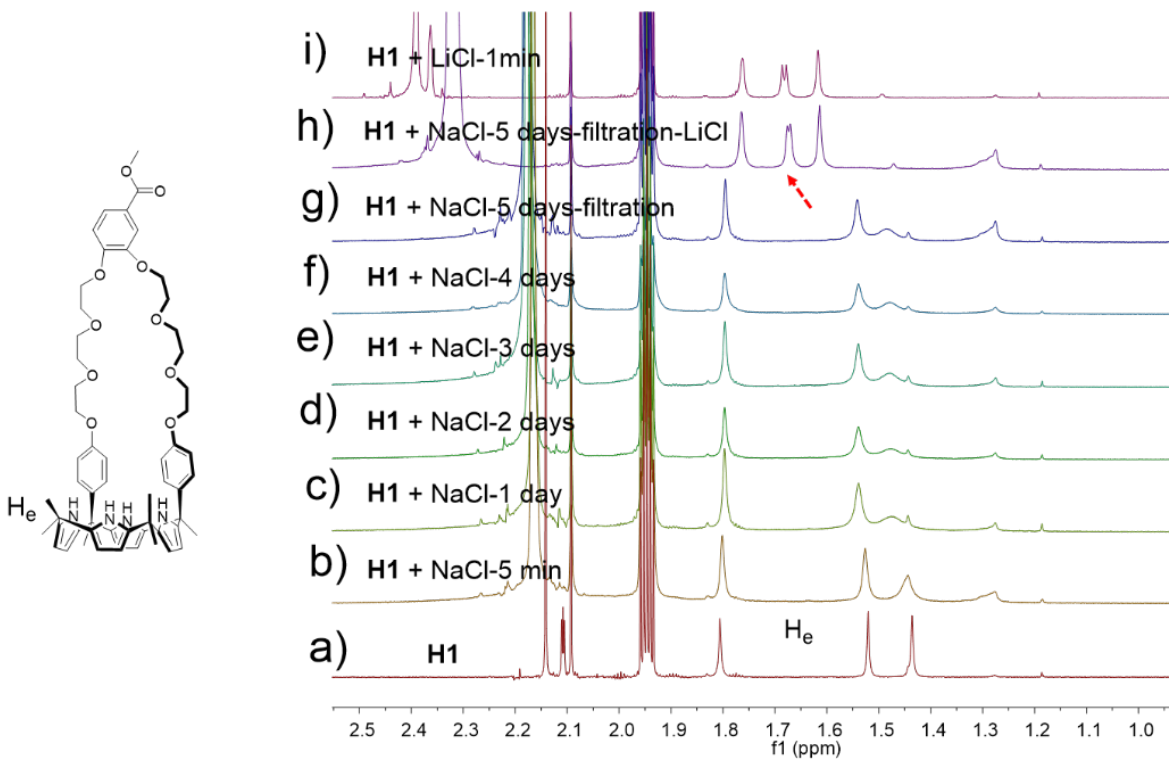

Figure S34. Partial ${ }^{1} \mathrm{H}$ NMR spectra (1.0-2.5) (400 MHz, $\left.\mathrm{CD}_{3} \mathrm{CN}, 298 \mathrm{~K}\right)$ of a) $5.00 \mathrm{mM}$ solution of H1; b) $5.00 \mathrm{mM}$ solution of $\mathbf{H 1}$ and 1 equiv of $\mathrm{NaCl}$ after mixing for $1 \mathrm{~min}$; c) $5.00 \mathrm{mM}$ solution of $\mathbf{H 1}$ and 1 equiv of $\mathrm{NaCl}$ after mixing for 1 day; d) $5.00 \mathrm{mM}$ solution of $\mathbf{H 1}$ and 1 equiv of $\mathrm{NaCl}$ after mixing for 2 days; e) $5.00 \mathrm{mM}$ solution of $\mathbf{H 1}$ and 1 equiv of $\mathrm{NaCl}$ after mixing for 3 days; f) $5.00 \mathrm{mM}$ solution of $\mathbf{H 1}$ and 1 equiv of $\mathrm{NaCl}$ after mixing for 4 days; g) filtered solution of $5.00 \mathrm{mM} \mathrm{H1}$ and 1 equiv of $\mathrm{NaCl}$ after mixing for 5 days; h) experiment described in $\mathrm{g}$ ) after adding 1 equiv of $\mathrm{LiCl}$; i) $5.00 \mathrm{mM}$ solution of $\mathbf{H 1}$ and 1 equiv of $\mathrm{LiCl}$ after mixing for $1 \mathrm{~min}$.

\subsection{Competition between $\mathrm{H} \mathbf{L} \supset \mathrm{LiCl}$ and $\mathrm{H} \mathbf{} \supset \mathrm{KCl}$}

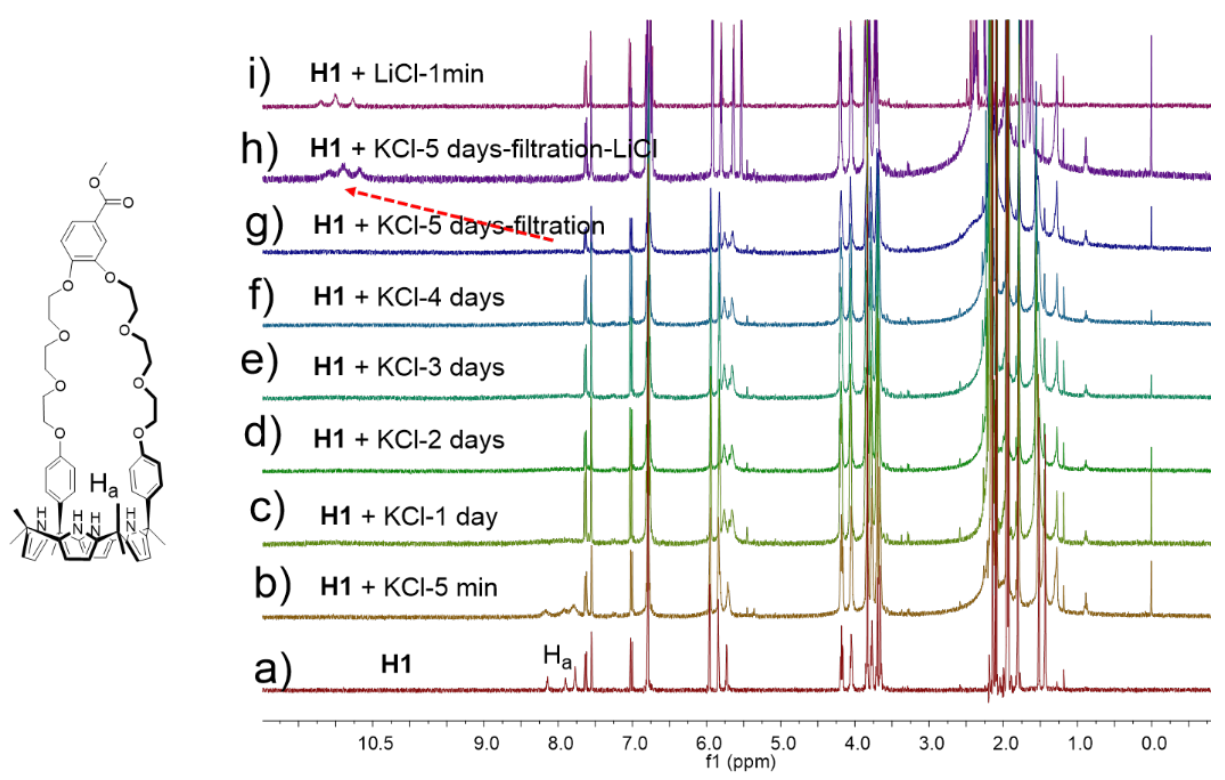

Figure S35. ${ }^{1} \mathrm{H}$ NMR spectra (400 MHz, $\mathrm{CD}_{3} \mathrm{CN}, 298 \mathrm{~K}$ ) of a) $5.00 \mathrm{mM}$ solution of $\mathbf{H 1}$; b) $5.00 \mathrm{mM}$ solution of $\mathbf{H 1}$ and 1 equiv of $\mathrm{KCl}$ after mixing for $1 \mathrm{~min}$; c) $5.00 \mathrm{mM}$ solution of $\mathbf{H 1}$ and 1 equiv of $\mathrm{KCl}$ after mixing for 1 day; d) $5.00 \mathrm{mM}$ solution of $\mathbf{H 1}$ and 1 equiv of $\mathrm{KCl}$ after mixing for 2 days; e) $5.00 \mathrm{mM}$ solution of $\mathbf{H 1}$ and 1 equiv of $\mathrm{KCl}$ after mixing for 3 days; f) $5.00 \mathrm{mM}$ solution of $\mathbf{H 1}$ and 1 equiv of $\mathrm{KCl}$ after mixing for 4 days; g) filtered solution of 
$5.00 \mathrm{mM} \mathrm{H1}$ and 1 equiv of $\mathrm{KCl}$ after mixing for 5 days; h) experiment described in $\mathrm{g}$ ) after adding 1 equiv of $\mathrm{LiCl}$; i) $5.00 \mathrm{mM} \mathrm{H1}$ and 1 equiv of $\mathrm{LiCl}$ after mixing for $1 \mathrm{~min}$.

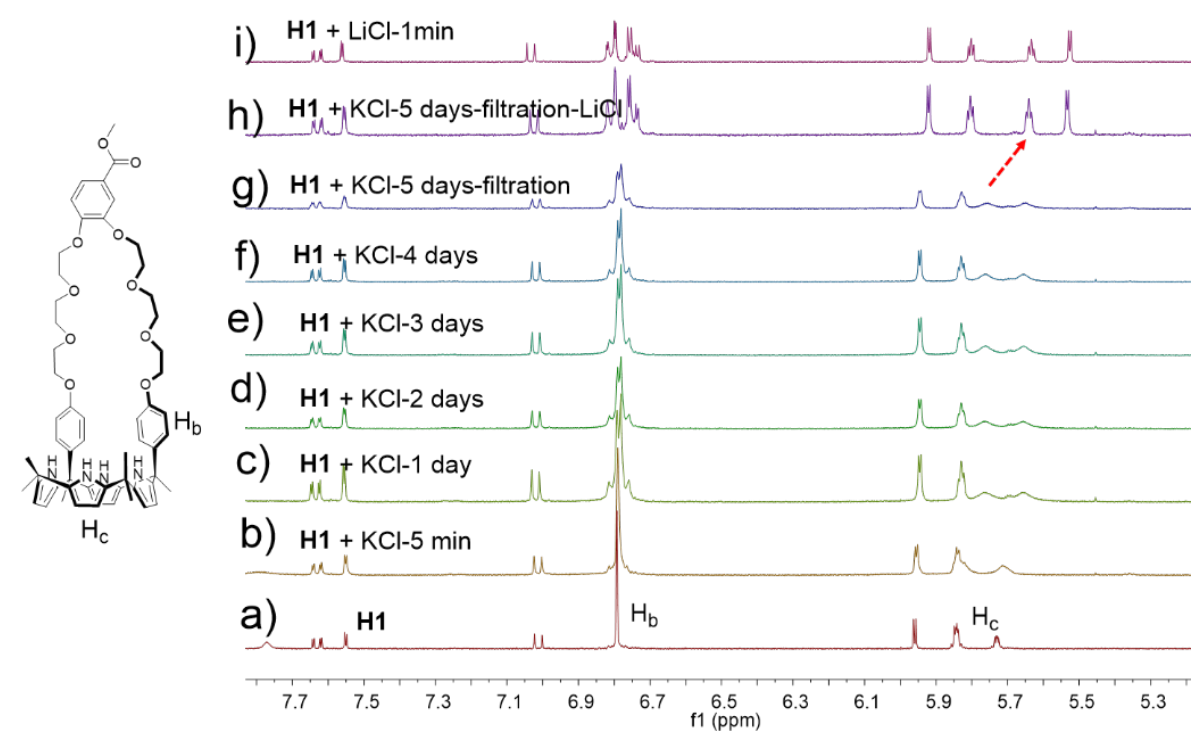

Figure S36. Partial ${ }^{1} \mathrm{H}$ NMR spectra (5.3-7.7) (400 MHz, $\mathrm{CD}_{3} \mathrm{CN}, 298 \mathrm{~K}$ ) of a) $5.00 \mathrm{mM}$ solution of H1; b) $5.00 \mathrm{mM}$ solution of $\mathbf{H 1}$ and 1 equiv of $\mathrm{KCl}$ after mixing for $1 \mathrm{~min}$; c) $5.00 \mathrm{mM}$ solution of $\mathbf{H 1}$ and 1 equiv of $\mathrm{KCl}$ after mixing for 1 day; d) $5.00 \mathrm{mM}$ solution of $\mathbf{H 1}$ and 1 equiv of $\mathrm{KCl}$ after mixing for 2 days; e) $5.00 \mathrm{mM}$ solution of $\mathbf{H 1}$ and 1 equiv of $\mathrm{KCl}$ after mixing for 3 days; f) $5.00 \mathrm{mM}$ solution of $\mathbf{H 1}$ and 1 equiv of $\mathrm{KCl}$ after mixing for 4 days; g) filtered solution of $5.00 \mathrm{mM} \mathrm{H1}$ and 1 equiv of $\mathrm{KCl}$ after mixing for 5 days; h) experiment described in g) after adding 1 equiv of $\mathrm{LiCl}$; i) $5.00 \mathrm{mM}$ solution of $\mathbf{H 1}$ and 1 equiv of $\mathrm{LiCl}$ after mixing for $1 \mathrm{~min}$.

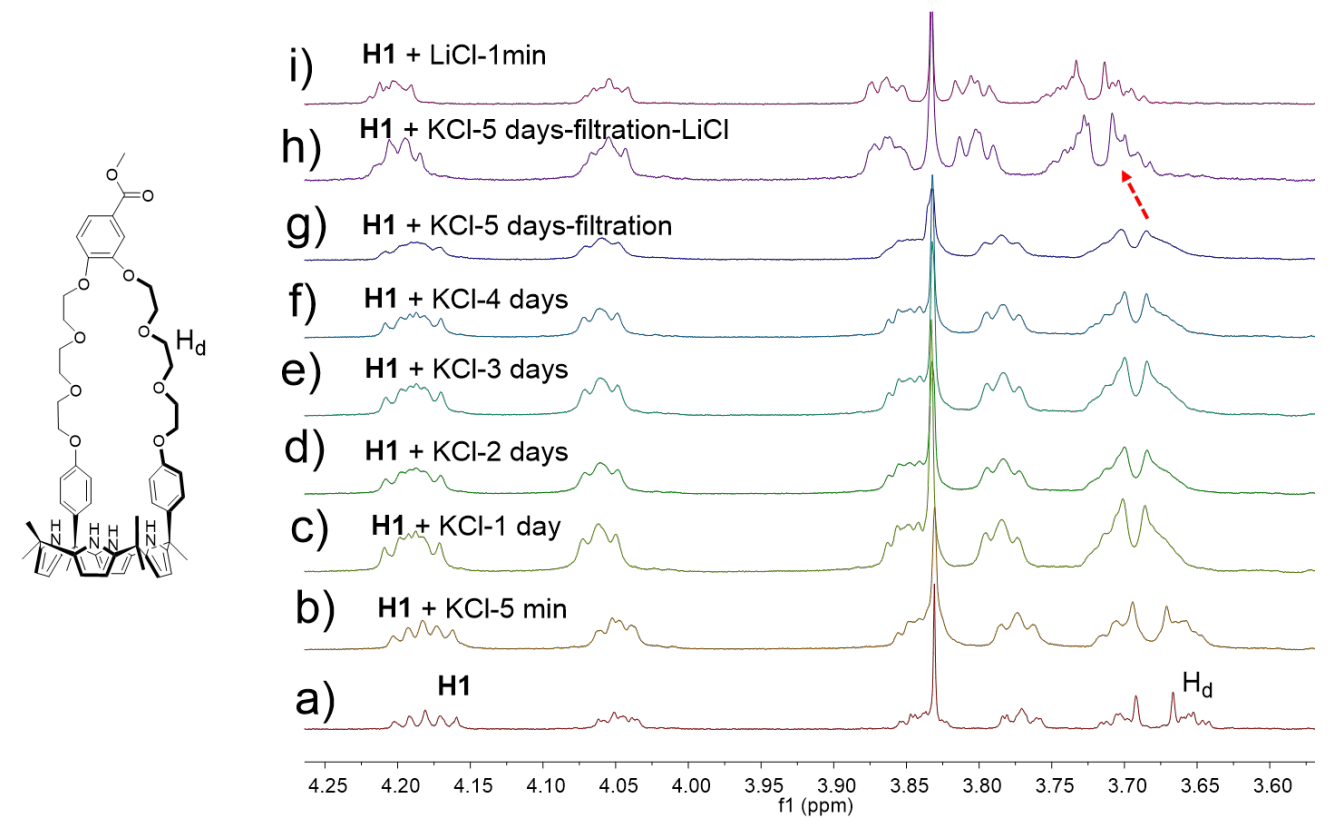

Figure S37. Partial ${ }^{1} \mathrm{H}$ NMR spectra (3.5-4.3) (400 MHz, $\left.\mathrm{CD}_{3} \mathrm{CN}, 298 \mathrm{~K}\right)$ of a) $5.00 \mathrm{mM}$ solution of $\mathbf{H 1}$; b) $5.00 \mathrm{mM}$ solution of $\mathbf{H 1}$ and 1 equiv of $\mathrm{KCl}$ after mixing for $1 \mathrm{~min}$; c) $5.00 \mathrm{mM}$ solution of $\mathbf{H 1}$ and 1 equiv of $\mathrm{KCl}$ after mixing for 1 day; d) $5.00 \mathrm{mM}$ solution of $\mathbf{H 1}$ and 1 equiv of $\mathrm{KCl}$ after mixing for 2 days; e) $5.00 \mathrm{mM}$ solution of $\mathbf{H} \mathbf{1}$ and 1 equiv of $\mathrm{KCl}$ after mixing for 3 days; f) $5.00 \mathrm{mM}$ solution of $\mathbf{H 1}$ and 1 equiv of $\mathrm{KCl}$ after mixing for 4 days; $\mathrm{g}$ ) 
filtered solution of $5.00 \mathrm{mM} \mathrm{H1}$ and 1 equiv of $\mathrm{KCl}$ after mixing for 5 days; h) experiment described in $\mathrm{g}$ ) after adding 1 equiv of $\mathrm{LiCl}$; i) $5.00 \mathrm{mM}$ solution of $\mathbf{H 1}$ and 1 equiv of $\mathrm{LiCl}$ after mixing for $1 \mathrm{~min}$.

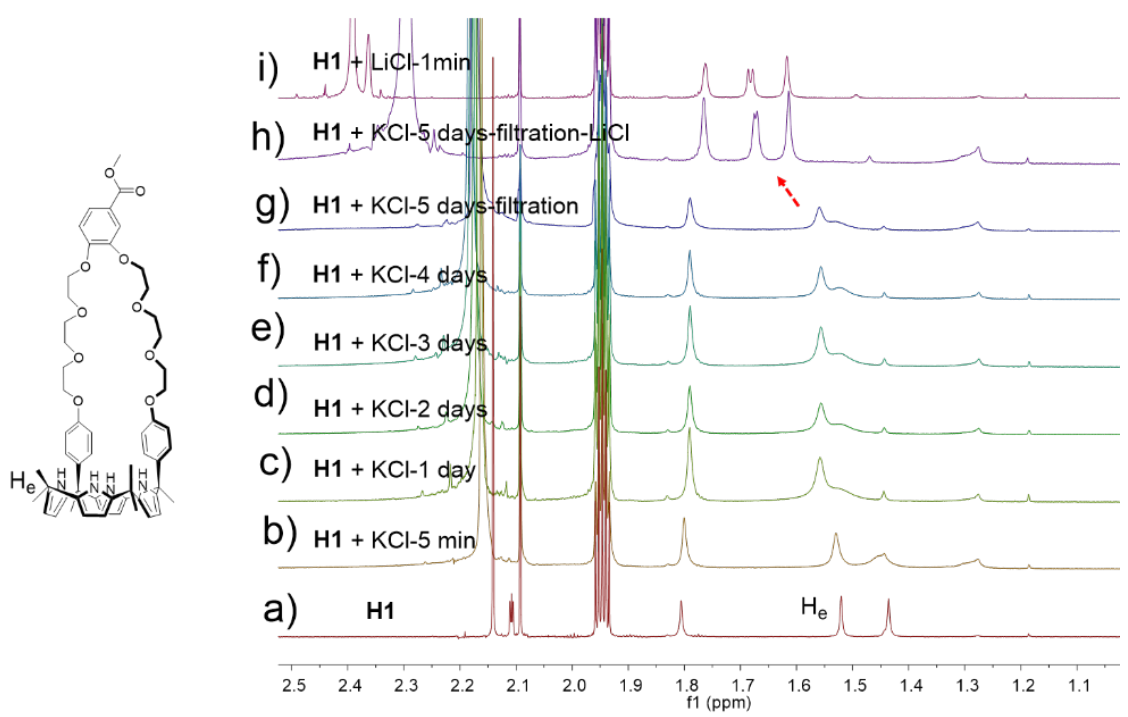

Figure S38. Partial ${ }^{1} \mathrm{H}$ NMR spectra (1.0-2.5) (400 MHz, CD 3 CN, $\left.298 \mathrm{~K}\right)$ of a) $5.00 \mathrm{mM}$ solution of H1; b) $5.00 \mathrm{mM}$ solution of $\mathbf{H 1}$ and 1 equiv of $\mathrm{KCl}$ after mixing for $1 \mathrm{~min}$; c) $5.00 \mathrm{mM}$ solution of $\mathbf{H 1}$ and 1 equiv of $\mathrm{KCl}$ after mixing for 1 day; d) $5.00 \mathrm{mM}$ solution of $\mathbf{H 1}$ and 1 equiv of $\mathrm{KCl}$ after mixing for 2 days; e) $5.00 \mathrm{mM}$ solution of $\mathbf{H 1}$ and 1 equiv of $\mathrm{KCl}$ after mixing for 3 days; f) $5.00 \mathrm{mM}$ solution of $\mathbf{H 1}$ and 1 equiv of $\mathrm{KCl}$ after mixing for 4 days; $\mathrm{g}$ ) filtered solution of $5.00 \mathrm{mM} \mathrm{H1}$ and 1 equiv of $\mathrm{KCl}$ after mixing for 5 days; h) experiment described in g) after adding 1 equiv of $\mathrm{LiCl}$; i) $5.00 \mathrm{mM}$ solution of $\mathbf{H 1}$ and 1 equiv of $\mathrm{LiCl}$ after mixing for $1 \mathrm{~min}$.

\subsection{Competition between $\mathrm{H} \mathbf{L} \mathrm{LiCl}$ and $\mathrm{H} \mathbf{S} \mathrm{MgCl}_{2}$}

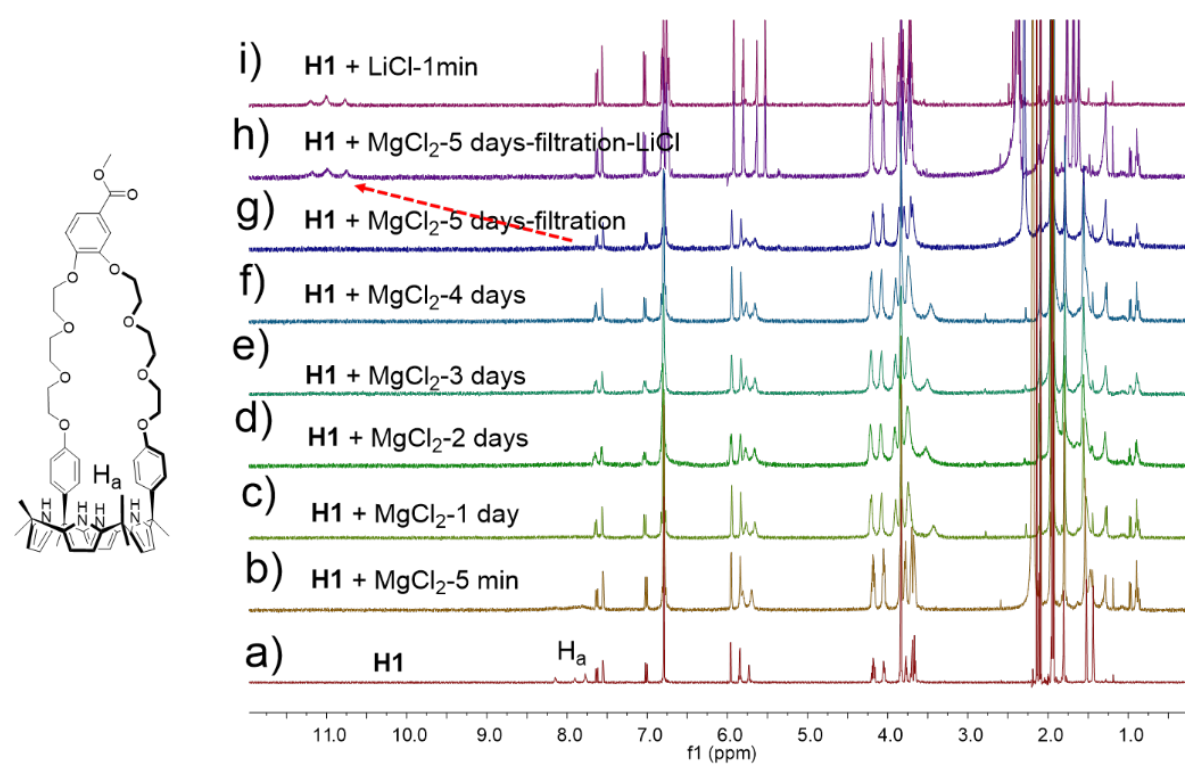

Figure S39. ${ }^{1} \mathrm{H}$ NMR spectra ( $400 \mathrm{MHz}, \mathrm{CD}_{3} \mathrm{CN}, 298 \mathrm{~K}$ ) of a) $5.00 \mathrm{mM}$ solution of $\mathbf{H 1}$; b) $5.00 \mathrm{mM}$ solution of $\mathbf{H 1}$ and 1 equiv of $\mathrm{MgCl}_{2}$ after mixing for $1 \mathrm{~min}$; c) $5.00 \mathrm{mM}$ solution of $\mathbf{H 1}$ and 1 equiv of $\mathrm{MgCl}_{2}$ after mixing for 1 day; d) $5.00 \mathrm{mM}$ solution of $\mathbf{H 1}$ and 1 equiv of $\mathrm{MgCl}_{2}$ after mixing for 2 days; e) $5.00 \mathrm{mM}$ solution of $\mathbf{H 1}$ and 1 equiv of $\mathrm{MgCl}_{2}$ after mixing for 3 days; f) $5.00 \mathrm{mM}$ solution of $\mathbf{H 1}$ and 1 equiv of $\mathrm{MgCl}_{2}$ after mixing for 4 days; 
g) filtered solution of $5.00 \mathrm{mM}$ solution of $\mathbf{H 1}$ and 1 equiv of $\mathrm{MgCl}_{2}$ after mixing for 5 days; h) experiment described in g) after adding 1 equiv of $\mathrm{LiCl}$; i) $5.00 \mathrm{mM}$ solution of $\mathbf{H 1}$ and 1 equiv of $\mathrm{LiCl}$ after mixing for $1 \mathrm{~min}$.

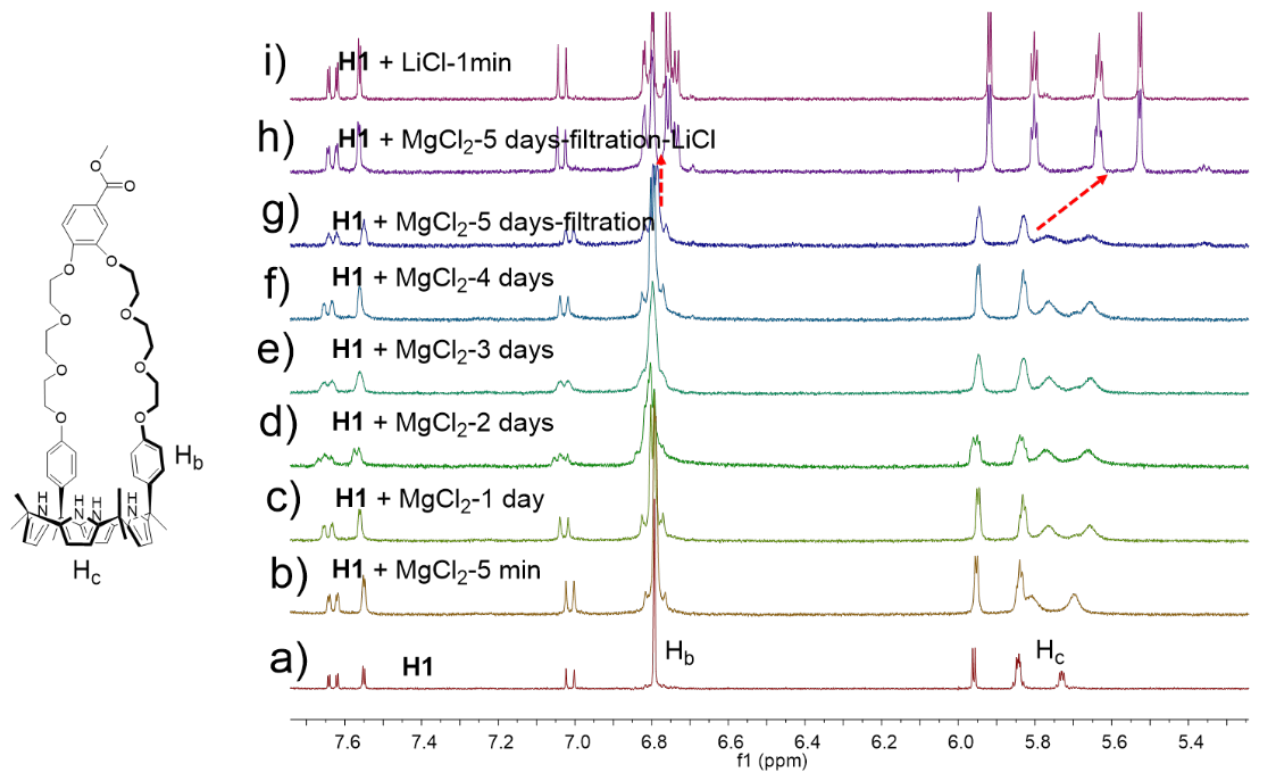

Figure S40. Partial ${ }^{1} \mathrm{H}$ NMR spectra (5.3-7.7) $\left(400 \mathrm{MHz}, \mathrm{CD}_{3} \mathrm{CN}, 298 \mathrm{~K}\right)$ of a) $5.00 \mathrm{mM}$ solution of H1; b) $5.00 \mathrm{mM}$ solution of $\mathbf{H 1}$ and 1 equiv of $\mathrm{MgCl}_{2}$ after mixing for $1 \mathrm{~min}$; c) $5.00 \mathrm{mM}$ solution of $\mathbf{H 1}$ and 1 equiv of $\mathrm{MgCl}_{2}$ after mixing for 1 day; d) $5.00 \mathrm{mM}$ solution of $\mathbf{H 1}$ and 1 equiv of $\mathrm{MgCl}_{2}$ after mixing for 2 days; e) $5.00 \mathrm{mM}$ solution of $\mathbf{H 1}$ and 1 equiv of $\mathrm{MgCl}_{2}$ after mixing for 3 days; f) $5.00 \mathrm{mM}$ solution of $\mathbf{H 1}$ and 1 equiv of $\mathrm{MgCl}_{2}$ after mixing for 4 days; g) filtered solution of $5.00 \mathrm{mM} \mathrm{H1}$ and 1 equiv of $\mathrm{MgCl}_{2}$ after mixing for 5 days; h) experiment shown in $\mathrm{g}$ ) after adding 1 equiv of $\mathrm{LiCl}$; i) $5.00 \mathrm{mM} \mathrm{H1}$ and 1 equiv of $\mathrm{LiCl}$ after mixing for $1 \mathrm{~min}$.

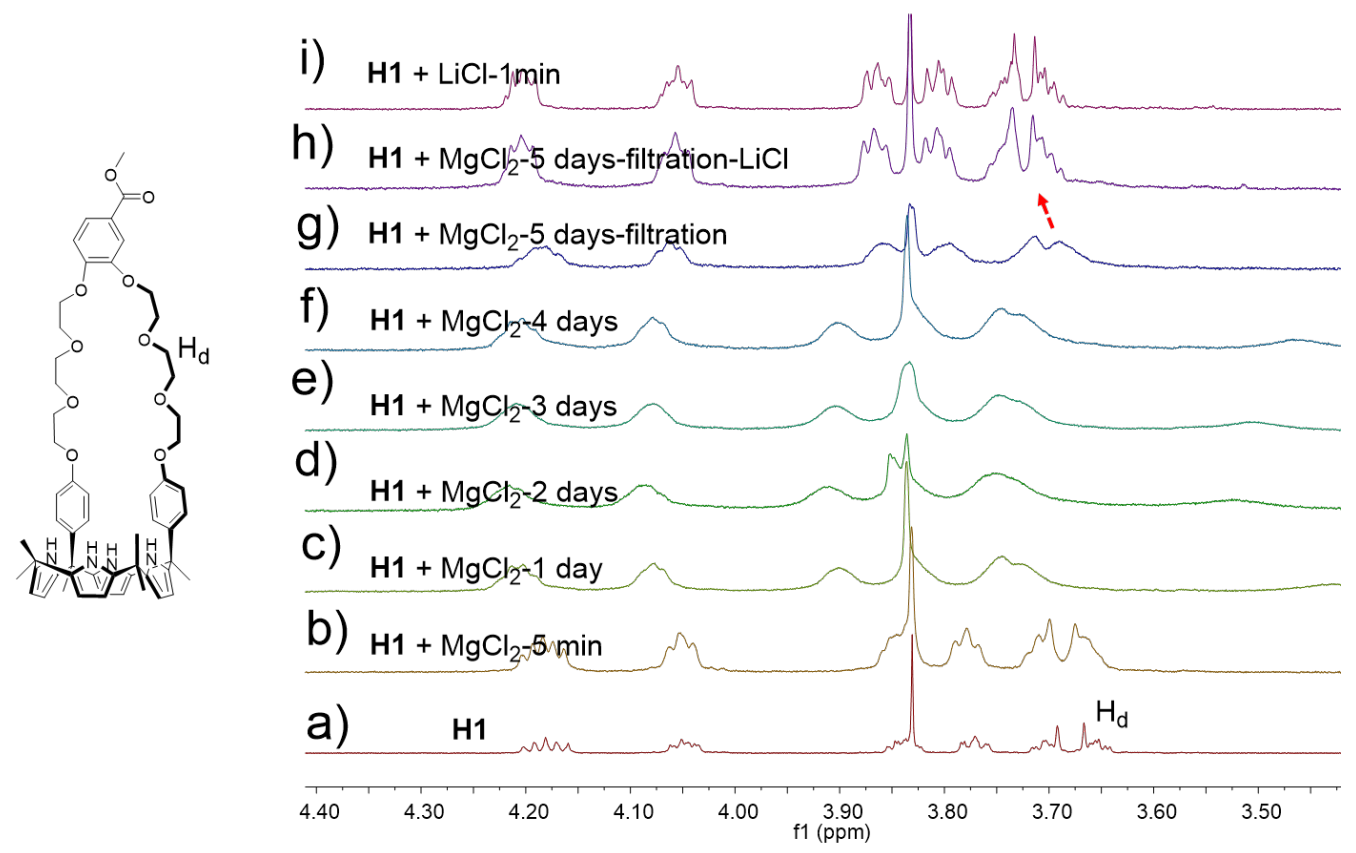

Figure S41. Partial ${ }^{1} \mathrm{H}$ NMR spectra (3.5-4.3) (400 MHz, CD $\left.{ }_{3} \mathrm{CN}, 298 \mathrm{~K}\right)$ of a) $5.00 \mathrm{mM}$ solution of H1; b) $5.00 \mathrm{mM}$ solution of $\mathbf{H 1}$ and 1 equiv of $\mathrm{MgCl}_{2}$ after mixing for $1 \mathrm{~min}$; c) $5.00 \mathrm{mM}$ solution of $\mathbf{H 1}$ and 1 equiv of $\mathrm{MgCl}_{2}$ after mixing for 1 day; d) 5.00 solution of $\mathrm{mM} \mathrm{H1}$ and 1 equiv of $\mathrm{MgCl}_{2}$ after mixing for 2 days; e) $5.00 \mathrm{mM}$ solution of $\mathbf{H 1}$ and 1 equiv of $\mathrm{MgCl}_{2}$ after mixing for 3 days; f) $5.00 \mathrm{mM}$ solution of $\mathbf{H 1}$ and 1 equiv of $\mathrm{MgCl}_{2}$ after mixing for 
4 days; g) filtered solution of $5.00 \mathrm{mM}$ solution of $\mathbf{H 1}$ and 1 equiv of $\mathrm{MgCl}_{2}$ after mixing for 5 days; h) experiment shown in g) after adding 1 equiv of $\mathrm{LiCl}$; i) $5.00 \mathrm{mM}$ solution of $\mathbf{H 1}$ and 1 equiv of $\mathrm{LiCl}$ after mixing for $1 \mathrm{~min}$.

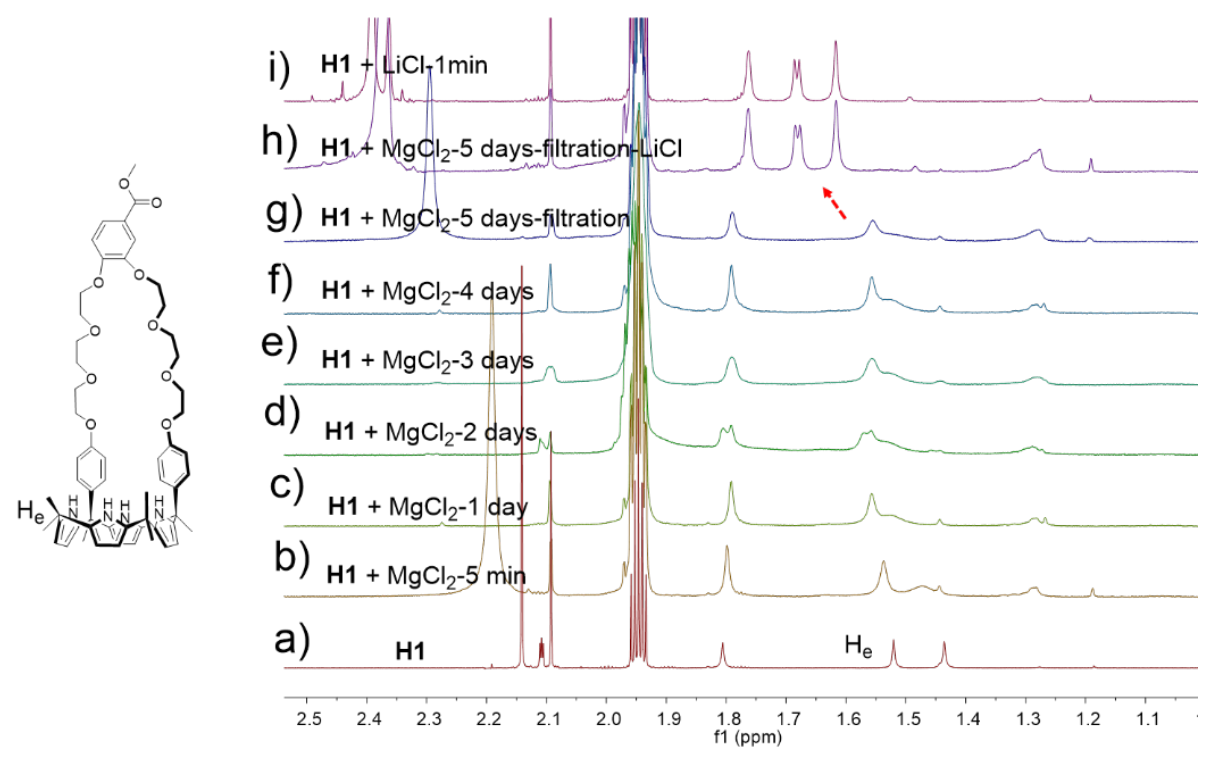

Figure S42. Partial ${ }^{1} \mathrm{H}$ NMR spectra (1.0-2.5) (400 MHz, CD $\left.{ }_{3} \mathrm{CN}, 298 \mathrm{~K}\right)$ of a) H1; a) $5.00 \mathrm{mM}$ solution of H1; b) $5.00 \mathrm{mM}$ solution of $\mathbf{H 1}$ and 1 equiv of $\mathrm{MgCl}_{2}$ after mixing for $\left.1 \mathrm{~min} ; \mathrm{c}\right) 5.00 \mathrm{mM}$ solution of $\mathbf{H 1}$ and 1 equiv of $\mathrm{MgCl}_{2}$ after mixing for 1 day; d) $5.00 \mathrm{mM}$ solution of $\mathbf{H 1}$ and 1 equiv of $\mathrm{MgCl}_{2}$ after mixing for 2 days; e) $5.00 \mathrm{mM}$ solution of $\mathbf{H 1}$ and 1 equiv of $\mathrm{MgCl}_{2}$ after mixing for 3 days; f) $5.00 \mathrm{mM}$ solution of $\mathbf{H 1}$ and 1 equiv of $\mathrm{MgCl}_{2}$ after mixing for 4 days; g) filtered solution of $5.00 \mathrm{mM}$ solution of $\mathbf{H 1}$ and 1 equiv of $\mathrm{MgCl}_{2}$ after mixing for 5 days; h) experiment shown in $\mathrm{g}$ ) after adding 1 equiv of $\mathrm{LiCl}$; i) $5.00 \mathrm{mM}$ solution of $\mathbf{H 1}$ and 1 equiv of $\mathrm{LiCl}$ after mixing for $1 \mathrm{~min}$.

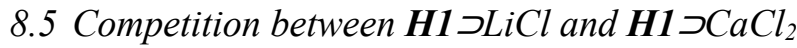

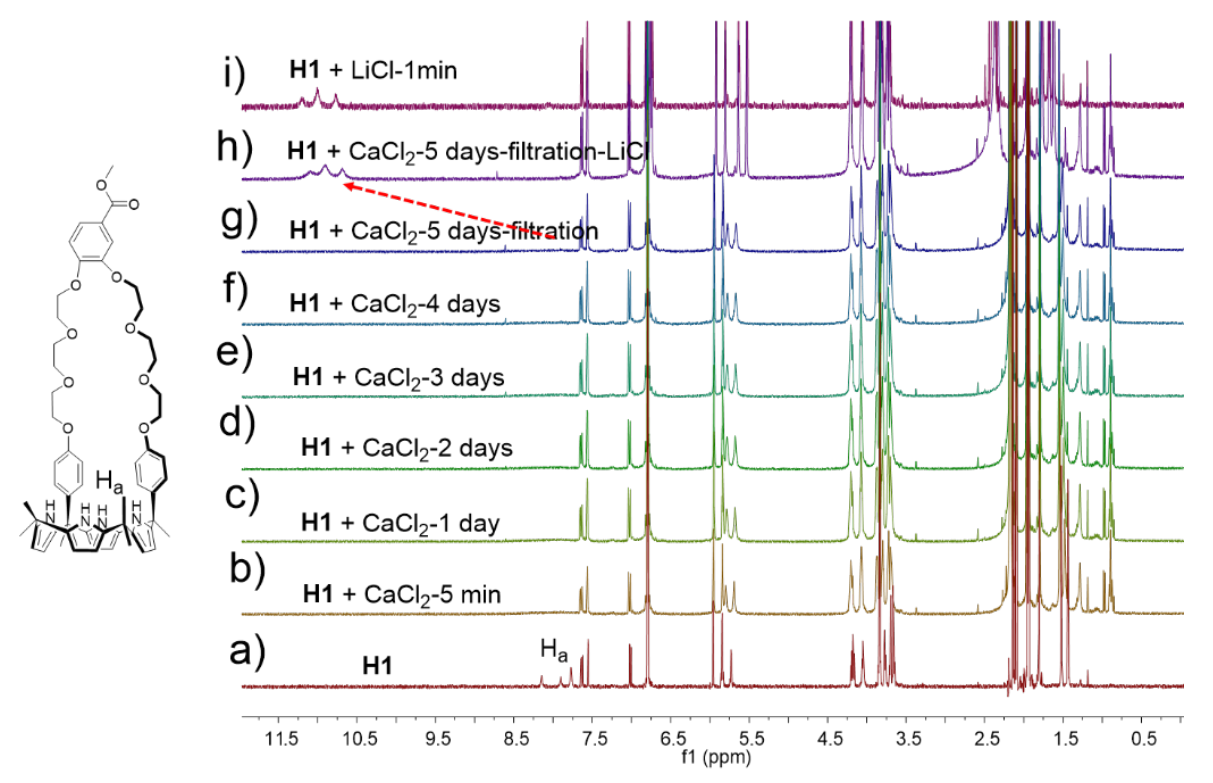

Figure S43. ${ }^{1} \mathrm{H}$ NMR spectra ( $400 \mathrm{MHz}, \mathrm{CD}_{3} \mathrm{CN}, 298 \mathrm{~K}$ ) of a) $5.00 \mathrm{mM}$ solution of $\mathbf{H 1}$; b) $5.00 \mathrm{mM}$ solution of $\mathbf{H 1}$ and 1 equiv of $\mathrm{CaCl}_{2}$ after mixing for $1 \mathrm{~min}$; c) $5.00 \mathrm{mM}$ solution of $\mathbf{H 1}$ and 1 equiv of $\mathrm{CaCl}_{2}$ after mixing for 1 day; d) $5.00 \mathrm{mM}$ solution of $\mathbf{H 1}$ and 1 equiv of $\mathrm{CaCl}_{2}$ after mixing for 2 days; e) $5.00 \mathrm{mM}$ solution of $\mathbf{H 1}$ and 1 
equiv of $\mathrm{CaCl}_{2}$ after mixing for 3 days; f) $5.00 \mathrm{mM}$ solution of $\mathbf{H 1}$ and 1 equiv of $\mathrm{CaCl}_{2}$ after mixing for 4 days; $\mathrm{g}$ ) filtered solution of $5.00 \mathrm{mM}$ solution of $\mathbf{H 1}$ and 1 equiv of $\mathrm{CaCl}_{2}$ after mixing for 5 days; h) experiment shown in g) after adding 1 equiv of $\mathrm{LiCl}$; i) $5.00 \mathrm{mM}$ solution of $\mathbf{H 1}$ and 1 equiv of $\mathrm{LiCl}$ after mixing for $1 \mathrm{~min}$.

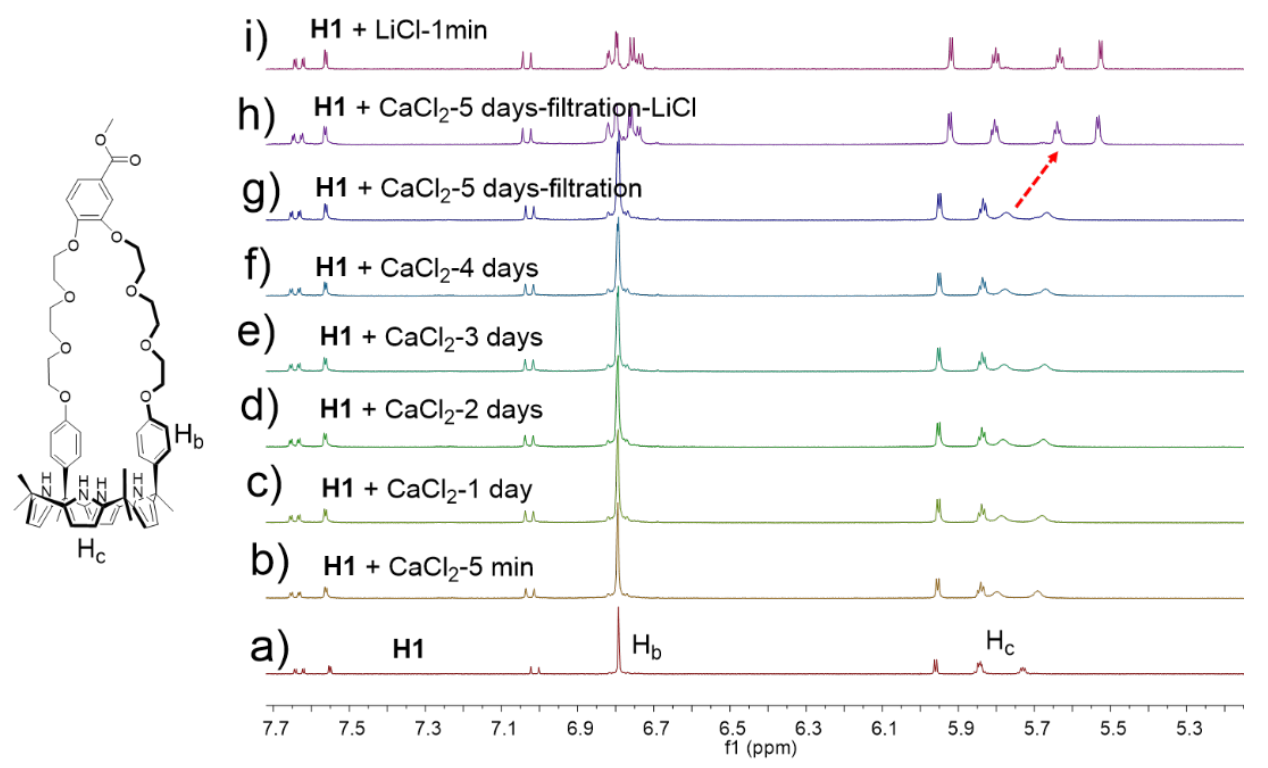

Figure S44. Partial ${ }^{1} \mathrm{H}$ NMR spectra (5.3-7.7) $\left(400 \mathrm{MHz}, \mathrm{CD}_{3} \mathrm{CN}, 298 \mathrm{~K}\right)$ of a) $5.00 \mathrm{mM}$ solution of H1; b) $5.00 \mathrm{mM}$ solution of $\mathbf{H 1}$ and 1 equiv of $\mathrm{CaCl}_{2}$ after mixing for $1 \mathrm{~min}$; c) $5.00 \mathrm{mM}$ solution of $\mathbf{H 1}$ and 1 equiv of $\mathrm{CaCl}_{2}$ after mixing for 1 day; d) $5.00 \mathrm{mM}$ solution of $\mathbf{H 1}$ and 1 equiv of $\mathrm{CaCl}_{2}$ after mixing for 2 days; e) $5.00 \mathrm{mM}$ solution of $\mathbf{H 1}$ and 1 equiv of $\mathrm{CaCl}_{2}$ after mixing for 3 days; f) $5.00 \mathrm{mM}$ solution of $\mathbf{H 1}$ and 1 equiv of $\mathrm{CaCl}_{2}$ after mixing for 4 days; g) filtered solution of $5.00 \mathrm{mM}$ solution of $\mathbf{H 1}$ and 1 equiv of $\mathrm{CaCl}_{2}$ after mixing for 5 days; h) experiment shown in $\mathrm{g}$ ) after adding 1 equiv of $\mathrm{LiCl}$; i) $5.00 \mathrm{mM}$ solution of $\mathbf{H 1}$ and 1 equiv of $\mathrm{LiCl}$ after mixing for $1 \mathrm{~min}$.

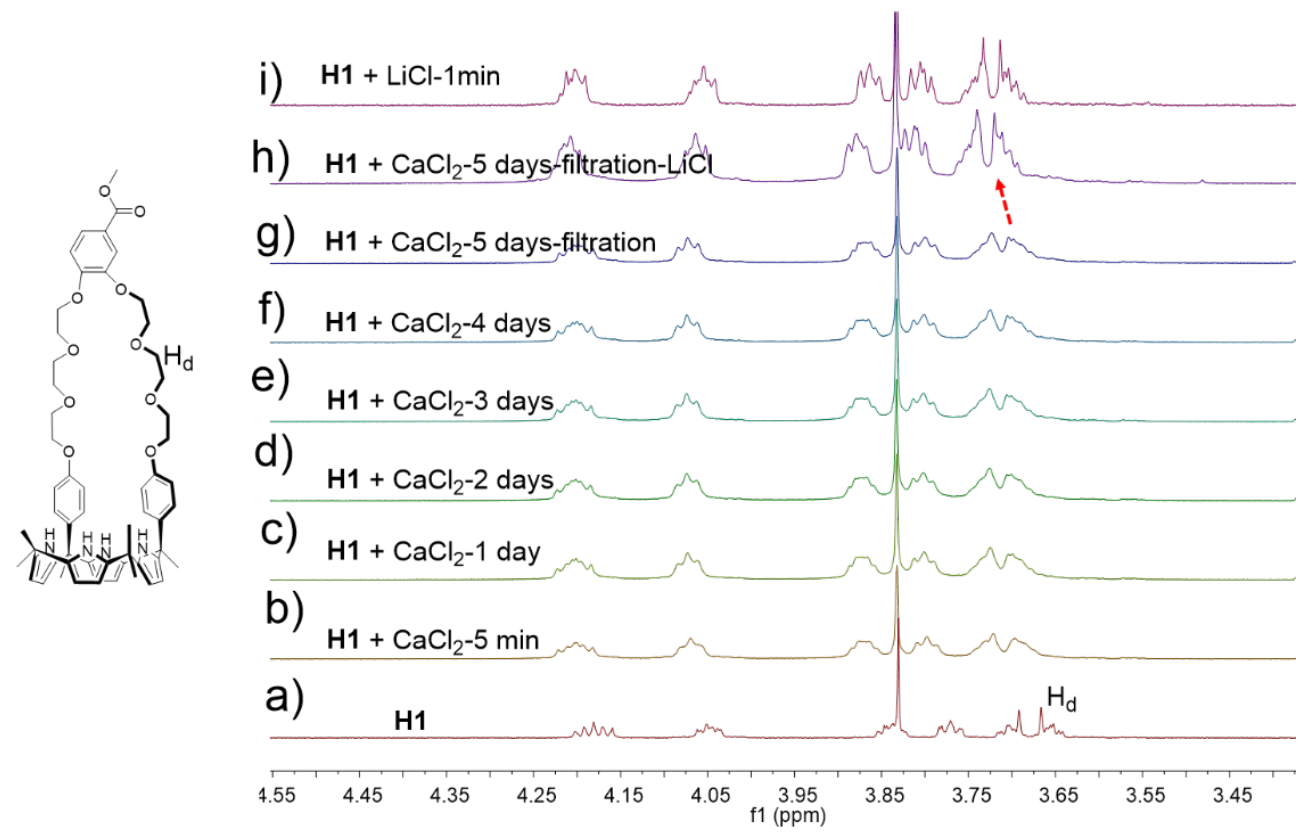

Figure S45. Partial ${ }^{1} \mathrm{H}$ NMR spectra (3.5-4.3) (400 MHz, CD $\left.{ }_{3} \mathrm{CN}, 298 \mathrm{~K}\right)$ of a) $5.00 \mathrm{mM}$ solution of H1; b) $5.00 \mathrm{mM}$ solution of $\mathbf{H 1}$ and 1 equiv of $\mathrm{CaCl}_{2}$ after mixing for $1 \mathrm{~min}$; c) $5.00 \mathrm{mM}$ solution of $\mathbf{H 1}$ and 1 equiv of $\mathrm{CaCl}_{2}$ after 
mixing for 1 day; d) $5.00 \mathrm{mM}$ solution of $\mathbf{H 1}$ and 1 equiv of $\mathrm{CaCl}_{2}$ after mixing for 2 days; e) $5.00 \mathrm{mM}$ solution of $\mathbf{H 1}$ and 1 equiv of $\mathrm{CaCl}_{2}$ after mixing for 3 days; f) $5.00 \mathrm{mM}$ solution of $\mathbf{H 1}$ and 1 equiv of $\mathrm{CaCl}_{2}$ after mixing for 4 days; g) filtered solution of $5.00 \mathrm{mM}$ solution of $\mathbf{H 1}$ and 1 equiv of $\mathrm{CaCl}_{2}$ after mixing for 5 days; h) experiment shown in g) after adding 1 equiv of $\mathrm{LiCl}$; i) $5.00 \mathrm{mM}$ solution of $\mathbf{H 1}$ and 1 equiv of $\mathrm{LiCl}$ after mixing for $1 \mathrm{~min}$.
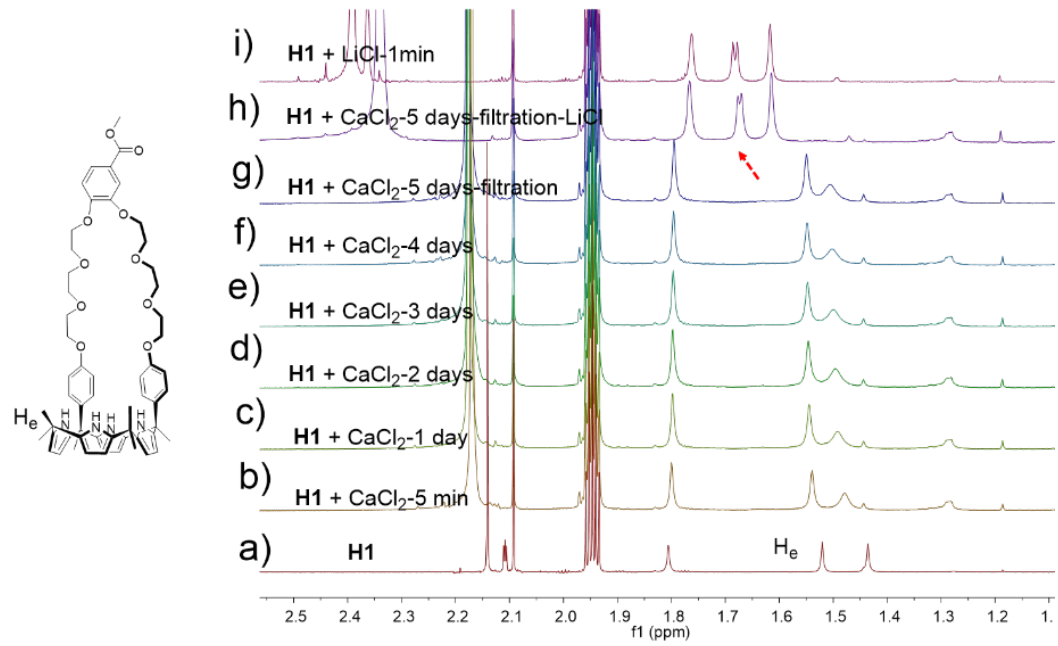

Figure S46. Partial ${ }^{1} \mathrm{H}$ NMR spectra (1.0-2.5) (400 MHz, $\left.\mathrm{CD}_{3} \mathrm{CN}, 298 \mathrm{~K}\right)$ of a) $5.00 \mathrm{mM}$ solution of H1; b) $5.00 \mathrm{mM}$ solution of $\mathbf{H 1}$ and 1 equiv of $\mathrm{CaCl}_{2}$ after mixing for $1 \mathrm{~min}$; c) $5.00 \mathrm{mM}$ solution of $\mathbf{H 1}$ and 1 equiv of $\mathrm{CaCl}_{2}$ after mixing for 1 day; d) $5.00 \mathrm{mM}$ solution of $\mathbf{H 1}$ and 1 equiv of $\mathrm{CaCl}_{2}$ after mixing for 2 days; e) $5.00 \mathrm{mM}$ solution of $\mathbf{H 1}$ and 1 equiv of $\mathrm{CaCl}_{2}$ after mixing for 3 days; f) $5.00 \mathrm{mM}$ solution of $\mathbf{H 1}$ and 1 equiv of $\mathrm{CaCl}_{2}$ after mixing for 4 days; g) filtered solution of $5.00 \mathrm{mM}$ solution of $\mathbf{H 1}$ and 1 equiv of $\mathrm{CaCl}_{2}$ after mixing for 5 days; h) experiment shown in $\mathrm{g}$ ) after adding 1 equiv of $\mathrm{LiCl}$; i) $5.00 \mathrm{mM}$ solution of $\mathbf{H 1}$ and 1 equiv of $\mathrm{LiCl}$ after mixing for $1 \mathrm{~min}$.

8.6 Complexation between $\mathrm{H1}$ and mixture of $\mathrm{LiCl}, \mathrm{NaCl}, \mathrm{KCl}, \mathrm{MgCl}_{2}$ and $\mathrm{CaCl}_{2}$

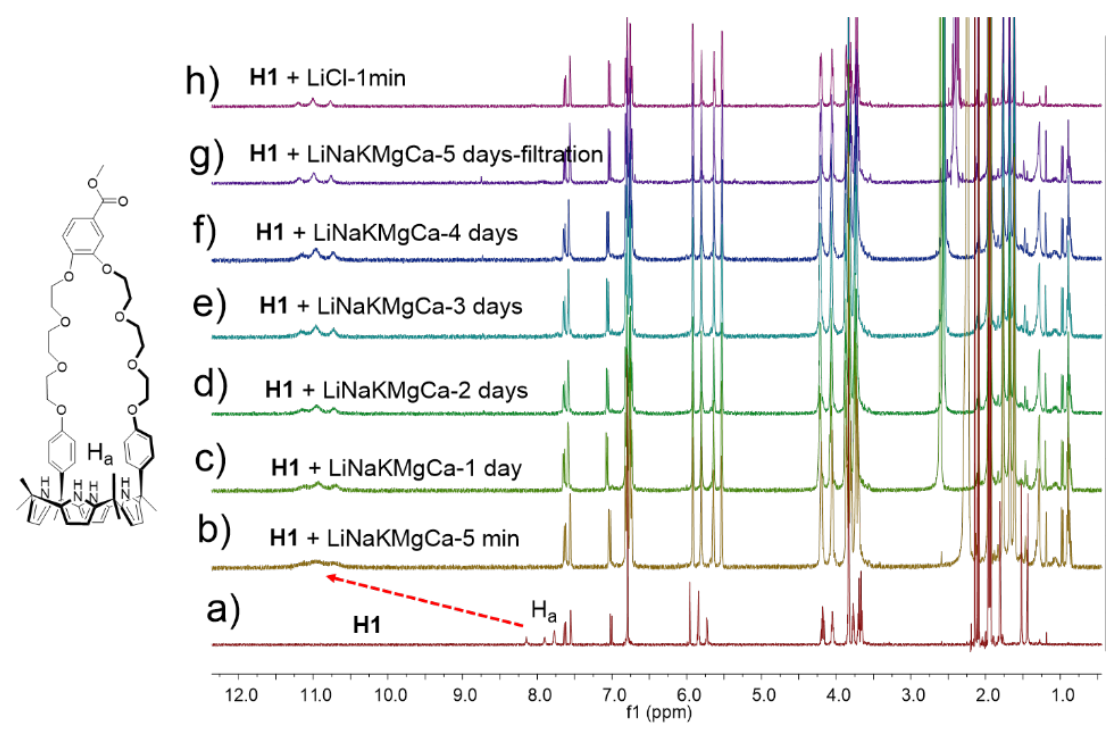

Figure S47. ${ }^{1} \mathrm{H}$ NMR spectra (400 MHz, $\mathrm{CD}_{3} \mathrm{CN}, 298 \mathrm{~K}$ ) of a) $5.00 \mathrm{mM}$ solution of $\mathbf{H 1}$; b) $5.00 \mathrm{mM}$ solution of $\mathbf{H 1}$ and 1 equiv of five salts $\left(\mathrm{LiCl}, \mathrm{NaCl}, \mathrm{KCl}, \mathrm{MgCl}_{2}\right.$ and $\left.\mathrm{CaCl}_{2}\right)$ after mixing for $1 \mathrm{~min}$; c) $5.00 \mathrm{mM}$ solution of $\mathbf{H 1}$ and 1 equiv of five salts ( $\mathrm{LiCl}, \mathrm{NaCl}, \mathrm{KCl}, \mathrm{MgCl}_{2}$ and $\mathrm{CaCl}_{2}$ ) after mixing for 1 day; d) $5.00 \mathrm{mM}$ solution of $\mathbf{H 1}$ and 1 equiv of five salts ( $\mathrm{LiCl}, \mathrm{NaCl}, \mathrm{KCl}, \mathrm{MgCl}_{2}$ and $\mathrm{CaCl}_{2}$ ) after mixing for 2 days; e) $5.00 \mathrm{mM}$ solution of $\mathbf{H 1}$ and 1 
equiv of five salts ( $\mathrm{LiCl}, \mathrm{NaCl}, \mathrm{KCl}, \mathrm{MgCl}_{2}$ and $\mathrm{CaCl}_{2}$ ) after mixing for 3 days; f) $5.00 \mathrm{mM}$ solution of $\mathbf{H 1}$ and 1 equiv of five salts ( $\mathrm{LiCl}, \mathrm{NaCl}, \mathrm{KCl}, \mathrm{MgCl}_{2}$ and $\mathrm{CaCl}_{2}$ ) after mixing for 4 days; $\mathrm{g}$ ) filtered $5.00 \mathrm{mM}$ solution of $\mathbf{H 1}$ and 1 equiv of five salts ( $\mathrm{LiCl}, \mathrm{NaCl}, \mathrm{KCl}, \mathrm{MgCl}_{2}$ and $\mathrm{CaCl}_{2}$ ) after mixing for after mixing for 5 days; h) $5.00 \mathrm{mM}$ solution of $\mathbf{H 1}$ and 1 equiv of $\mathrm{LiCl}$ after mixing for $1 \mathrm{~min}$.

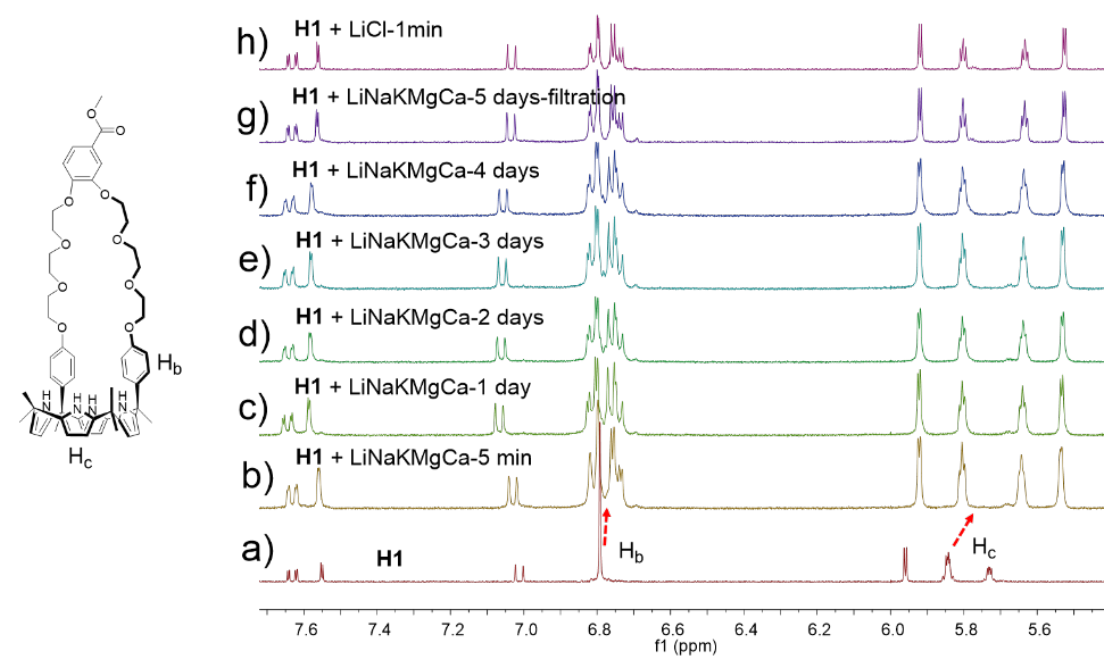

Figure S48. Partial ${ }^{1} \mathrm{H}$ NMR spectra (5.3-7.7) (400 MHz, $\mathrm{CD}_{3} \mathrm{CN}, 298 \mathrm{~K}$ ) of a) $5.00 \mathrm{mM}$ solution of H1; b) $5.00 \mathrm{mM}$ solution of $\mathbf{H 1}$ and 1 equiv of five salts ( $\mathrm{LiCl}, \mathrm{NaCl}, \mathrm{KCl}, \mathrm{MgCl}_{2}$ and $\mathrm{CaCl}_{2}$ ) after mixing for $1 \mathrm{~min}$; c) $5.00 \mathrm{mM}$ solution of $\mathbf{H 1}$ and 1 equiv of five salts ( $\mathrm{LiCl}, \mathrm{NaCl}, \mathrm{KCl}, \mathrm{MgCl}_{2}$ and $\mathrm{CaCl}_{2}$ ) after mixing for 1 day; d) $5.00 \mathrm{mM}$ solution of $\mathbf{H 1}$ and 1 equiv of five salts ( $\mathrm{LiCl}, \mathrm{NaCl}, \mathrm{KCl}, \mathrm{MgCl}_{2}$ and $\mathrm{CaCl}_{2}$ ) after mixing for 2 days; e) $5.00 \mathrm{mM}$ solution of $\mathbf{H 1}$ and 1 equiv of five salts ( $\mathrm{LiCl}, \mathrm{NaCl}, \mathrm{KCl}, \mathrm{MgCl}_{2}$ and $\left.\mathrm{CaCl}_{2}\right)$ after mixing for 3 days; f) $5.00 \mathrm{mM}$ solution of $\mathbf{H 1}$ and 1 equiv of five salts $\left(\mathrm{LiCl}, \mathrm{NaCl}, \mathrm{KCl}, \mathrm{MgCl}_{2}\right.$ and $\left.\mathrm{CaCl}_{2}\right)$ after mixing for 4 days; $\mathrm{g}$ ) filtered 5.00 $\mathrm{mM}$ solution of $\mathbf{H 1}$ and 1 equiv of five salts ( $\mathrm{LiCl}, \mathrm{NaCl}, \mathrm{KCl}, \mathrm{MgCl}_{2}$ and $\mathrm{CaCl}_{2}$ ) after mixing for after mixing for 5 days; h) $5.00 \mathrm{mM}$ solution of $\mathbf{H 1}$ and 1 equiv of $\mathrm{LiCl}$ after mixing for $1 \mathrm{~min}$.

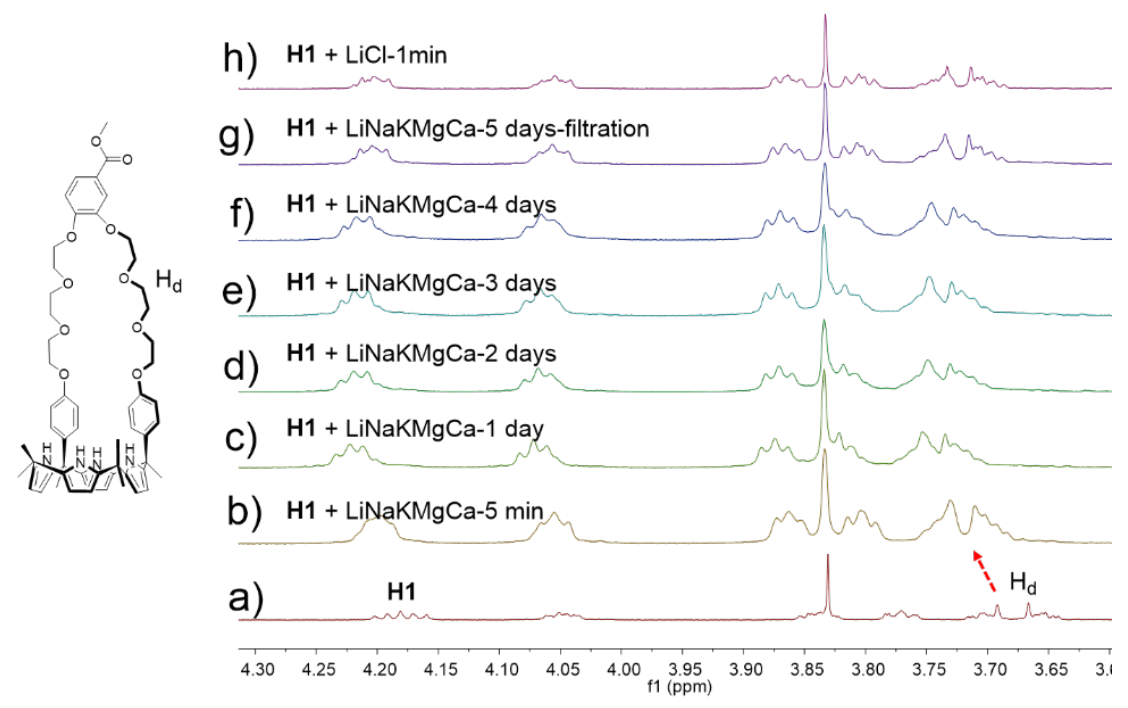

Figure S49. Partial ${ }^{1} \mathrm{H}$ NMR spectra (3.5-4.3) (400 MHz, $\left.\mathrm{CD}_{3} \mathrm{CN}, 298 \mathrm{~K}\right)$ of a) $5.00 \mathrm{mM}$ solution of H1; b) $5.00 \mathrm{mM}$ solution of $\mathbf{H 1}$ and 1 equiv of five salts $\left(\mathrm{LiCl}, \mathrm{NaCl}, \mathrm{KCl}, \mathrm{MgCl}_{2}\right.$ and $\mathrm{CaCl}_{2}$ ) after mixing for $1 \mathrm{~min}$; c) $5.00 \mathrm{mM}$ solution of $\mathbf{H 1}$ and 1 equiv of five salts ( $\mathrm{LiCl}, \mathrm{NaCl}, \mathrm{KCl}, \mathrm{MgCl}_{2}$ and $\mathrm{CaCl}_{2}$ ) after mixing for 1 day; d) $5.00 \mathrm{mM}$ solution of $\mathbf{H 1}$ and 1 equiv of five salts $\left(\mathrm{LiCl}, \mathrm{NaCl}, \mathrm{KCl}, \mathrm{MgCl}_{2}\right.$ and $\left.\mathrm{CaCl}_{2}\right)$ after mixing for 2 days; e) $5.00 \mathrm{mM}$ 
solution of $\mathbf{H 1}$ and 1 equiv of five salts ( $\mathrm{LiCl}, \mathrm{NaCl}, \mathrm{KCl}, \mathrm{MgCl}_{2}$ and $\left.\mathrm{CaCl}_{2}\right)$ after mixing for 3 days; f) $5.00 \mathrm{mM}$ solution of $\mathbf{H 1}$ and 1 equiv of five salts $\left(\mathrm{LiCl}, \mathrm{NaCl}, \mathrm{KCl}, \mathrm{MgCl}_{2}\right.$ and $\left.\mathrm{CaCl}_{2}\right)$ after mixing for 4 days; $\mathrm{g}$ ) filtered 5.00 $\mathrm{mM}$ solution of $\mathbf{H 1}$ and 1 equiv of five salts ( $\mathrm{LiCl}, \mathrm{NaCl}, \mathrm{KCl}, \mathrm{MgCl}_{2}$ and $\mathrm{CaCl}_{2}$ ) after mixing for after mixing for 5 days; h) $5.00 \mathrm{mM}$ solution of $\mathbf{H 1}$ and 1 equiv of $\mathrm{LiCl}$ after mixing for $1 \mathrm{~min}$.

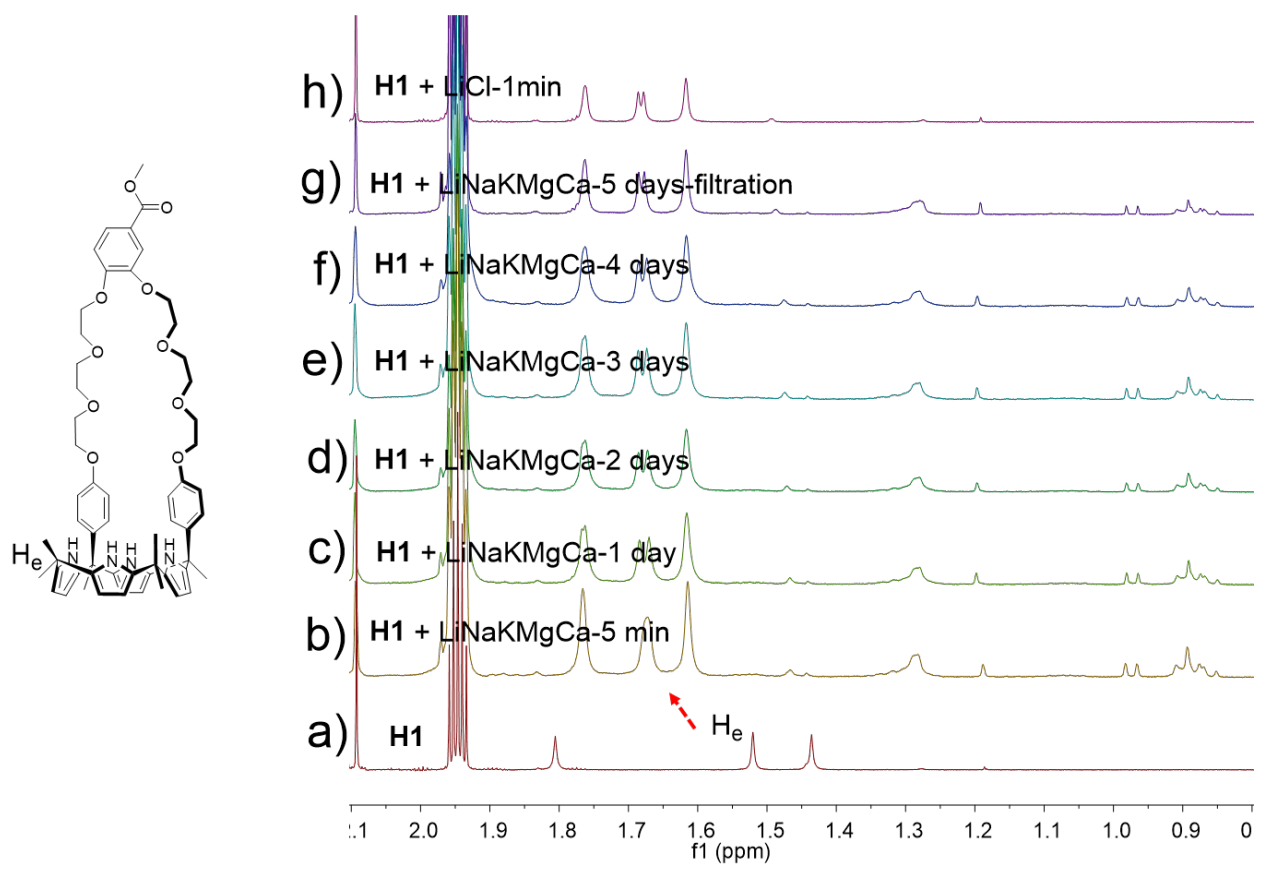

Figure S50. Partial ${ }^{1} \mathrm{H}$ NMR spectra (1.0-2.5) (400 MHz, CD $\left.{ }_{3} \mathrm{CN}, 298 \mathrm{~K}\right)$ of a) $5.00 \mathrm{mM}$ solution of H1; b) $5.00 \mathrm{mM}$ solution of $\mathbf{H 1}$ and 1 equiv of five salts ( $\mathrm{LiCl}, \mathrm{NaCl}, \mathrm{KCl}, \mathrm{MgCl}_{2}$ and $\mathrm{CaCl}_{2}$ ) after mixing for $1 \mathrm{~min}$; c) $5.00 \mathrm{mM}$ solution of $\mathbf{H 1}$ and 1 equiv of five salts ( $\mathrm{LiCl}, \mathrm{NaCl}, \mathrm{KCl}, \mathrm{MgCl}_{2}$ and $\mathrm{CaCl}_{2}$ ) after mixing for 1 day; d) $5.00 \mathrm{mM}$ solution of $\mathbf{H 1}$ and 1 equiv of five salts $\left(\mathrm{LiCl}, \mathrm{NaCl}, \mathrm{KCl}, \mathrm{MgCl}_{2}\right.$ and $\left.\mathrm{CaCl}_{2}\right)$ after mixing for 2 days; e) $5.00 \mathrm{mM}$ solution of $\mathbf{H 1}$ and 1 equiv of five salts ( $\mathrm{LiCl}, \mathrm{NaCl}, \mathrm{KCl}, \mathrm{MgCl}_{2}$ and $\mathrm{CaCl}_{2}$ ) after mixing for 3 days; f) $5.00 \mathrm{mM}$ solution of $\mathbf{H 1}$ and 1 equiv of five salts $\left(\mathrm{LiCl}, \mathrm{NaCl}, \mathrm{KCl}, \mathrm{MgCl}_{2}\right.$ and $\left.\mathrm{CaCl}_{2}\right)$ after mixing for 4 days; $\mathrm{g}$ ) filtered 5.00 $\mathrm{mM}$ solution of $\mathbf{H 1}$ and 1 equiv of five salts ( $\mathrm{LiCl}, \mathrm{NaCl}, \mathrm{KCl}, \mathrm{MgCl}_{2}$ and $\mathrm{CaCl}_{2}$ ) after mixing for after mixing for 5 days; h) $5.00 \mathrm{mM}$ solution of $\mathbf{H 1}$ and 1 equiv of $\mathrm{LiCl}$ after mixing for $1 \mathrm{~min}$. 
9. Interactions of $\boldsymbol{H} 2$ with $\mathrm{LiCl}, \mathrm{NaCl}, \mathrm{KCl}, \mathrm{MgCl}_{2}$ and $\mathrm{CaCl}_{2}$

9.1 Changes in the complexation of $\boldsymbol{H} \mathbf{2}$ and LiCl over time

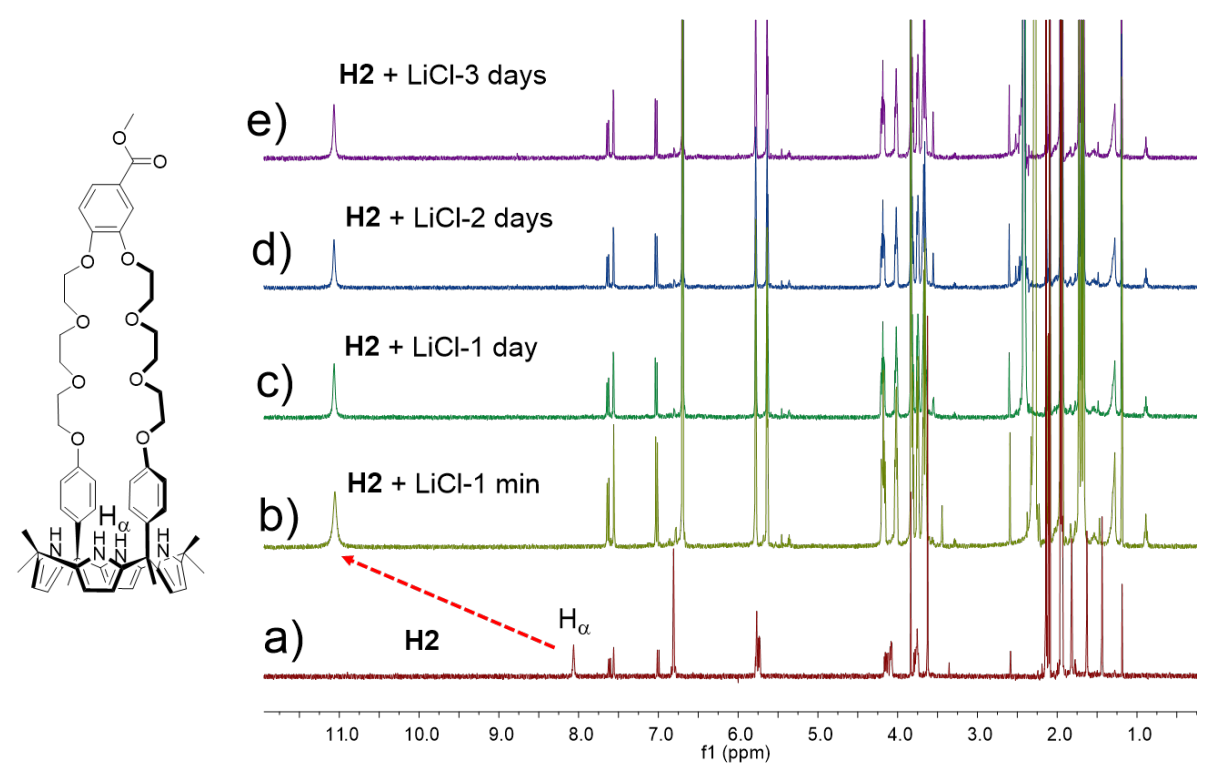

Figure S51. ${ }^{1} \mathrm{H}$ NMR spectra (400 MHz, $\mathrm{CD}_{3} \mathrm{CN}, 298 \mathrm{~K}$ ) of a) $5.00 \mathrm{mM}$ solution of $\mathbf{H 2}$; b) $5.00 \mathrm{mM}$ solution of $\mathbf{H 2}$ and 1 equiv of $\mathrm{LiCl}$ after mixing for $1 \mathrm{~min}$; c) $5.00 \mathrm{mM}$ solution of $\mathbf{H 2}$ and 1 equiv of $\mathrm{LiCl}$ after mixing for 1 day; d) $5.00 \mathrm{mM}$ solution of $\mathbf{H} \mathbf{2}$ and 1 equiv of $\mathrm{LiCl}$ after mixing for 2 days; e) $5.00 \mathrm{mM}$ solution of $\mathbf{H} \mathbf{2}$ and 1 equiv of $\mathrm{LiCl}$ after mixing for 3 days.

\subsection{Competition between $\boldsymbol{H} 2 \supset \mathrm{LiCl}$ and $\boldsymbol{H} 2 \supset \mathrm{NaCl}$}

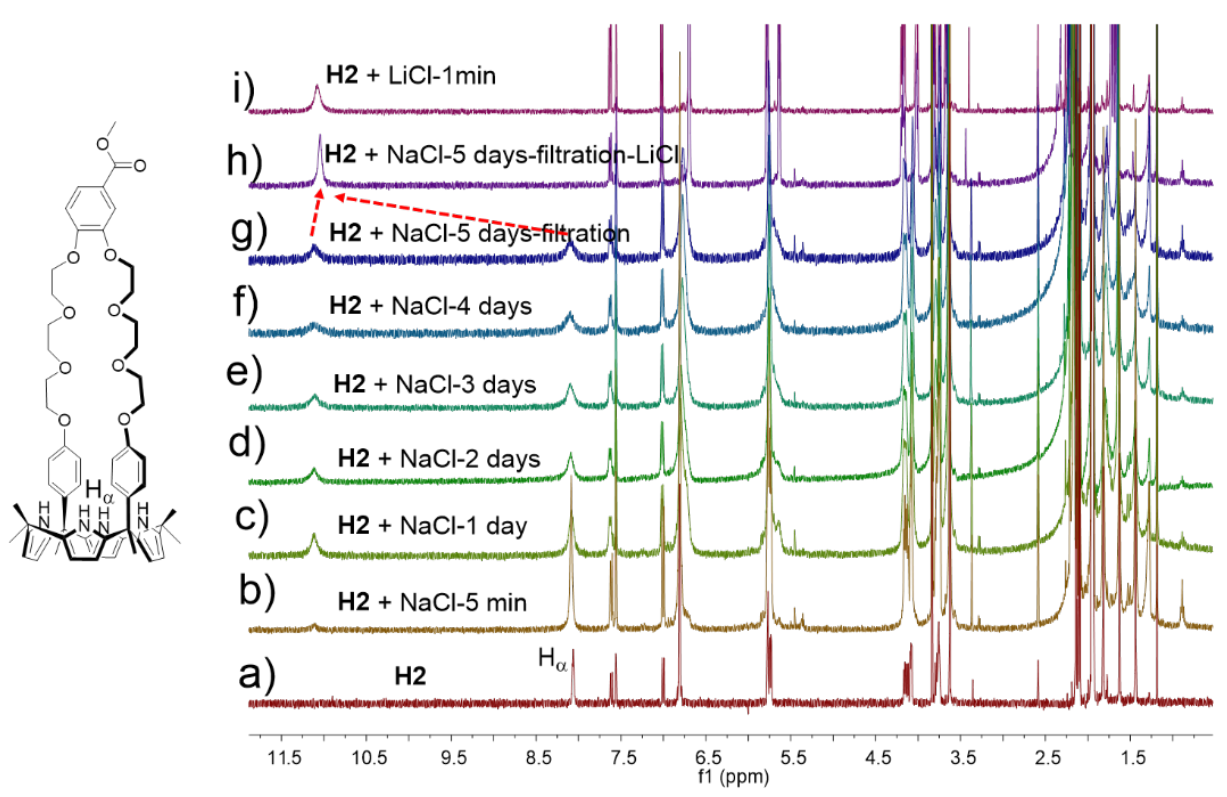

Figure S52. ${ }^{1} \mathrm{H}$ NMR spectra (400 MHz, $\mathrm{CD}_{3} \mathrm{CN}, 298 \mathrm{~K}$ ) of a) $5.00 \mathrm{mM}$ solution of $\mathbf{H 2}$; b) $5.00 \mathrm{mM}$ solution of $\mathbf{H 2}$ and 1 equiv of $\mathrm{NaCl}$ after mixing for $1 \mathrm{~min}$; c) $5.00 \mathrm{mM}$ solution of $\mathbf{H 2}$ and 1 equiv of $\mathrm{NaCl}$ after mixing for 1 day; d) $5.00 \mathrm{mM}$ solution of $\mathbf{H 2}$ and 1 equiv of $\mathrm{NaCl}$ after mixing for 2 days; e) $5.00 \mathrm{mM}$ solution of $\mathbf{H 2}$ and 1 equiv of $\mathrm{NaCl}$ after mixing for 3 days; f) $5.00 \mathrm{mM}$ solution of $\mathbf{H 2}$ and 1 equiv of $\mathrm{NaCl}$ after mixing for 4 days; $\mathrm{g}$ ) filtered solution of $5.00 \mathrm{mM}$ solution of $\mathbf{H 2}$ and 1 equiv of $\mathrm{NaCl}$ after mixing for 5 days; h) experiment shown in $\mathrm{g}$ ) after adding 1 equiv of $\mathrm{LiCl}$; i) $5.00 \mathrm{mM}$ solution of $\mathbf{H 2}$ and 1 equiv of $\mathrm{LiCl}$ after mixing for $1 \mathrm{~min}$. 


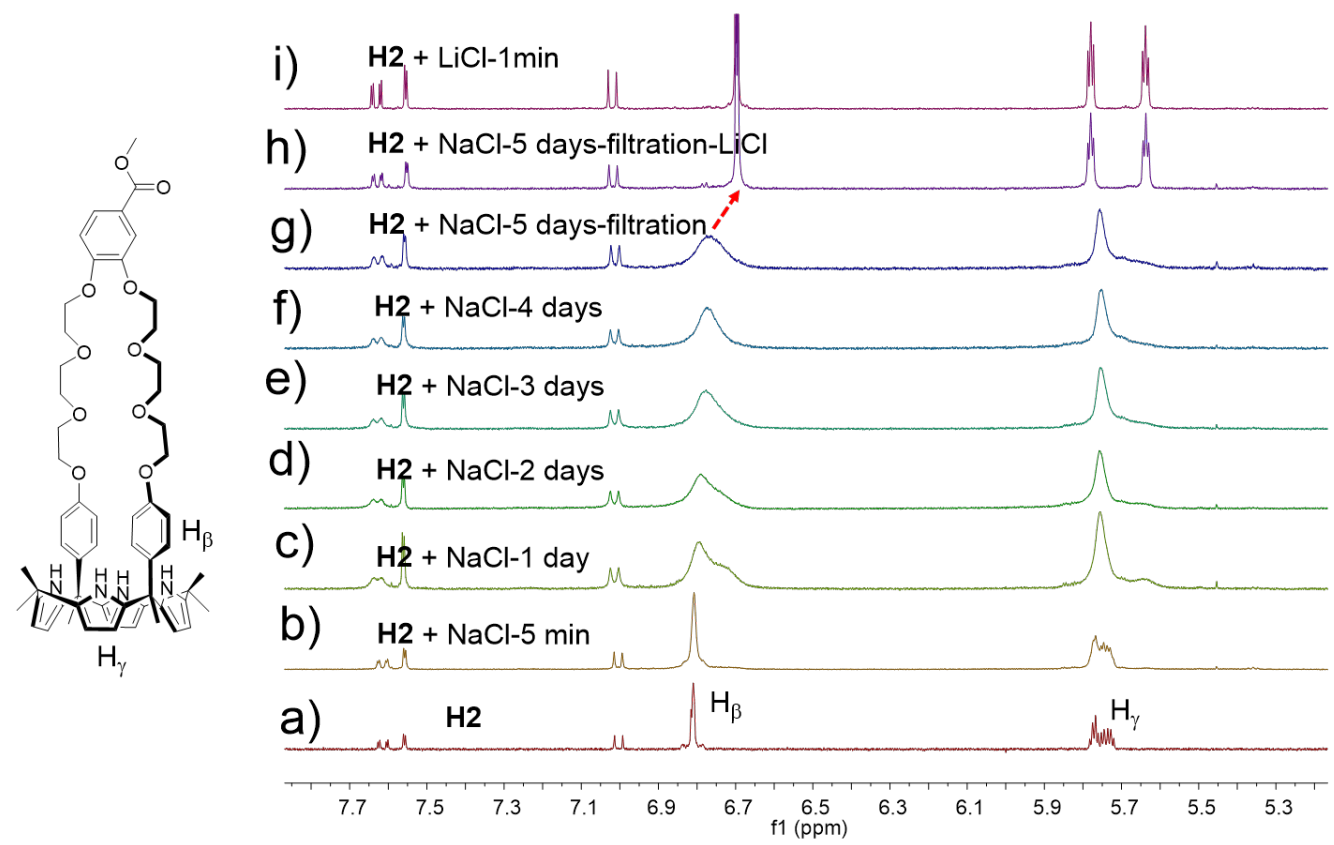

Figure S53. Partial ${ }^{1} \mathrm{H}$ NMR spectra (5.3-7.7) $\left(400 \mathrm{MHz}, \mathrm{CD}_{3} \mathrm{CN}, 298 \mathrm{~K}\right)$ of a) $5.00 \mathrm{mM}$ solution of $\mathbf{H 2}$; b) $5.00 \mathrm{mM}$ solution of $\mathbf{H 2}$ and 1 equiv of $\mathrm{NaCl}$ after mixing for $1 \mathrm{~min}$; c) $5.00 \mathrm{mM}$ solution of $\mathbf{H 2}$ and 1 equiv of $\mathrm{NaCl}$ after mixing for 1 day; d) $5.00 \mathrm{mM}$ solution of $\mathbf{H 2}$ and 1 equiv of $\mathrm{NaCl}$ after mixing for 2 days; e) $5.00 \mathrm{mM}$ solution of $\mathbf{H 2}$ and 1 equiv of $\mathrm{NaCl}$ after mixing for 3 days; f) $5.00 \mathrm{mM}$ solution of $\mathbf{H 2}$ and 1 equiv of $\mathrm{NaCl}$ after mixing for 4 days; g) filtered solution of $5.00 \mathrm{mM}$ solution of $\mathbf{H 2}$ and 1 equiv of $\mathrm{NaCl}$ after mixing for 5 days; h) experiment shown in $\mathrm{g}$ ) after adding 1 equiv of $\mathrm{LiCl}$; i) $5.00 \mathrm{mM}$ solution of $\mathbf{H 2}$ and 1 equiv of $\mathrm{LiCl}$ after mixing for $1 \mathrm{~min}$.

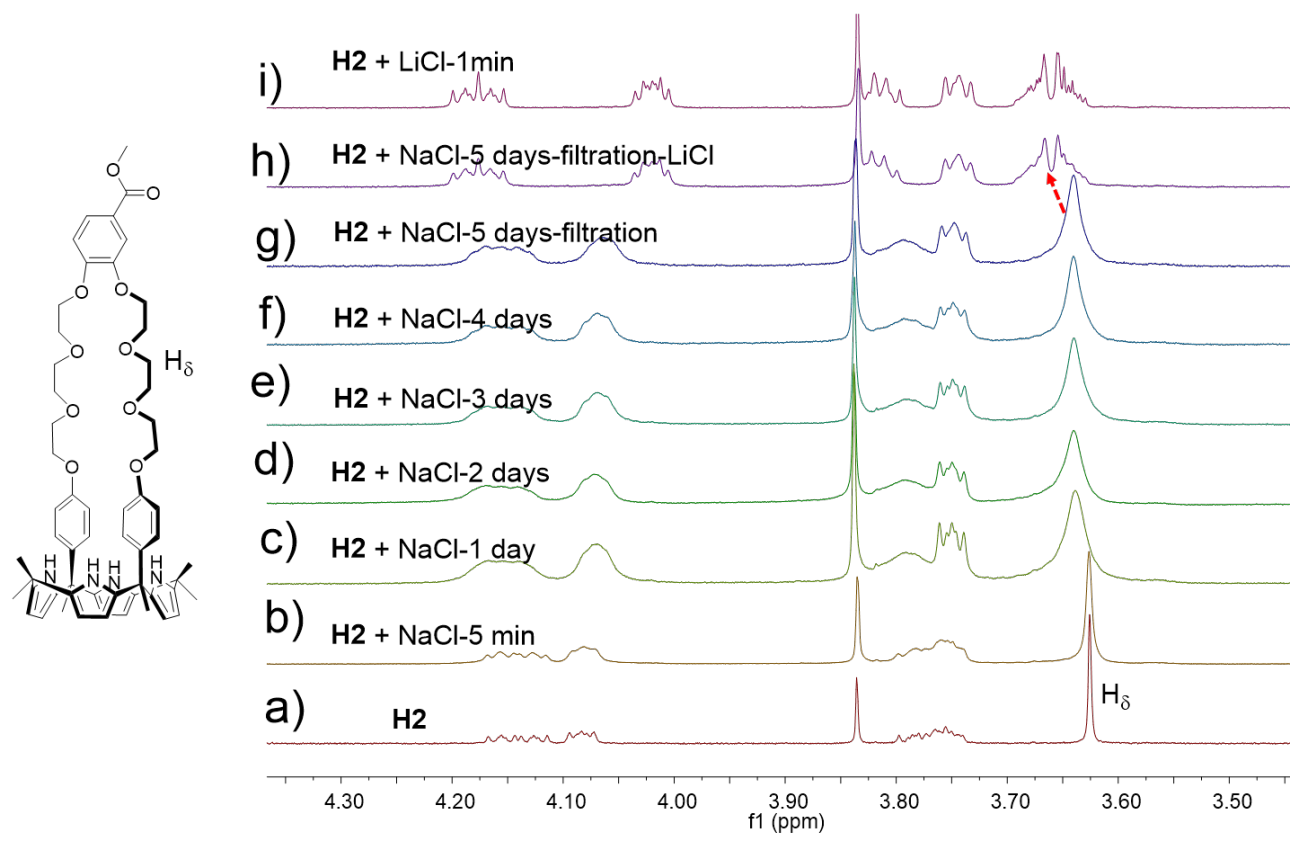

Figure S54. Partial ${ }^{1} \mathrm{H}$ NMR spectra (3.5-4.3) (400 MHz, $\mathrm{CD}_{3} \mathrm{CN}, 298 \mathrm{~K}$ ) of a) $5.00 \mathrm{mM}$ solution of H2; b) $5.00 \mathrm{mM}$ solution of $\mathbf{H 2}$ and 1 equiv of $\mathrm{NaCl}$ after mixing for $1 \mathrm{~min}$; c) $5.00 \mathrm{mM}$ solution of $\mathbf{H} \mathbf{2}$ and 1 equiv of $\mathrm{NaCl}$ after mixing for 1 day; d) $5.00 \mathrm{mM}$ solution of $\mathbf{H 2}$ and 1 equiv of $\mathrm{NaCl}$ after mixing for 2 days; e) $5.00 \mathrm{mM}$ solution of $\mathbf{H 2}$ and 1 equiv of $\mathrm{NaCl}$ after mixing for 3 days; f) $5.00 \mathrm{mM}$ solution of $\mathbf{H 2}$ and 1 equiv of $\mathrm{NaCl}$ after mixing for 4 days; g) filtered solution of $5.00 \mathrm{mM}$ solution of $\mathbf{H 2}$ and 1 equiv of $\mathrm{NaCl}$ after mixing for 5 days; h) experiment shown in g) after adding 1 equiv of $\mathrm{LiCl}$; i) $5.00 \mathrm{mM}$ solution of $\mathbf{H 2}$ and 1 equiv of $\mathrm{LiCl}$ after mixing for $1 \mathrm{~min}$. 


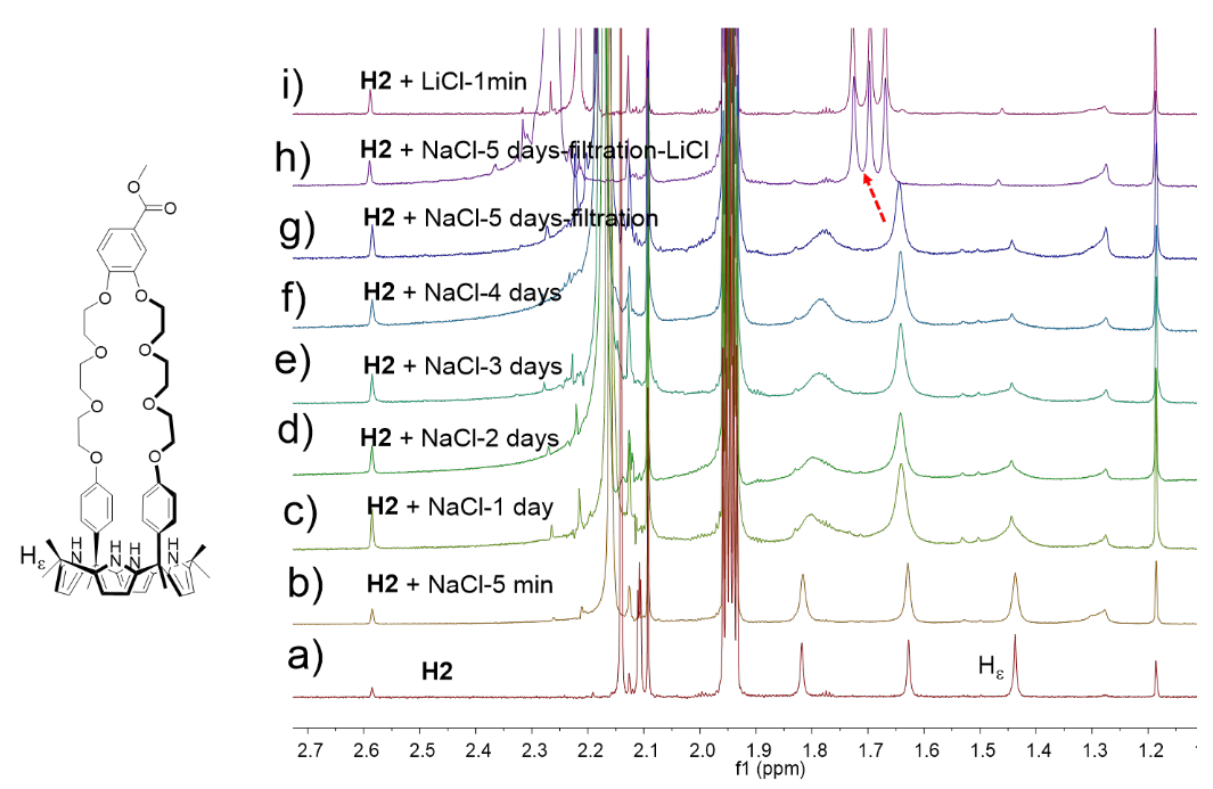

Figure S55. Partial ${ }^{1} \mathrm{H}$ NMR spectra (1.0-2.5) (400 MHz, CD $\left.{ }_{3} \mathrm{CN}, 298 \mathrm{~K}\right)$ of a) $5.00 \mathrm{mM}$ solution of $\mathbf{H 2}$; b) $5.00 \mathrm{mM}$ solution of $\mathbf{H 2}$ and 1 equiv of $\mathrm{NaCl}$ after mixing for $1 \mathrm{~min}$; c) $5.00 \mathrm{mM}$ solution of $\mathbf{H 2}$ and 1 equiv of $\mathrm{NaCl}$ after mixing for 1 day; d) $5.00 \mathrm{mM}$ solution of $\mathbf{H 2}$ and 1 equiv of $\mathrm{NaCl}$ after mixing for 2 days; e) $5.00 \mathrm{mM}$ solution of $\mathbf{H 2}$ and 1 equiv of $\mathrm{NaCl}$ after mixing for 3 days; f) $5.00 \mathrm{mM}$ solution of $\mathbf{H 2}$ and 1 equiv of $\mathrm{NaCl}$ after mixing for 4 days; g) filtered solution of $5.00 \mathrm{mM}$ solution of $\mathbf{H 2}$ and 1 equiv of $\mathrm{NaCl}$ after mixing for 5 days; h) experiment shown in $\mathrm{g}$ ) after adding 1 equiv of $\mathrm{LiCl}$; i) $5.00 \mathrm{mM}$ solution of $\mathbf{H 2}$ and 1 equiv of $\mathrm{LiCl}$ after mixing for $1 \mathrm{~min}$.

\subsection{Competition between $\boldsymbol{H} \mathbf{2} \supset \mathrm{LiCl}$ and $\boldsymbol{H} \mathbf{2} \supset \mathrm{KCl}$}

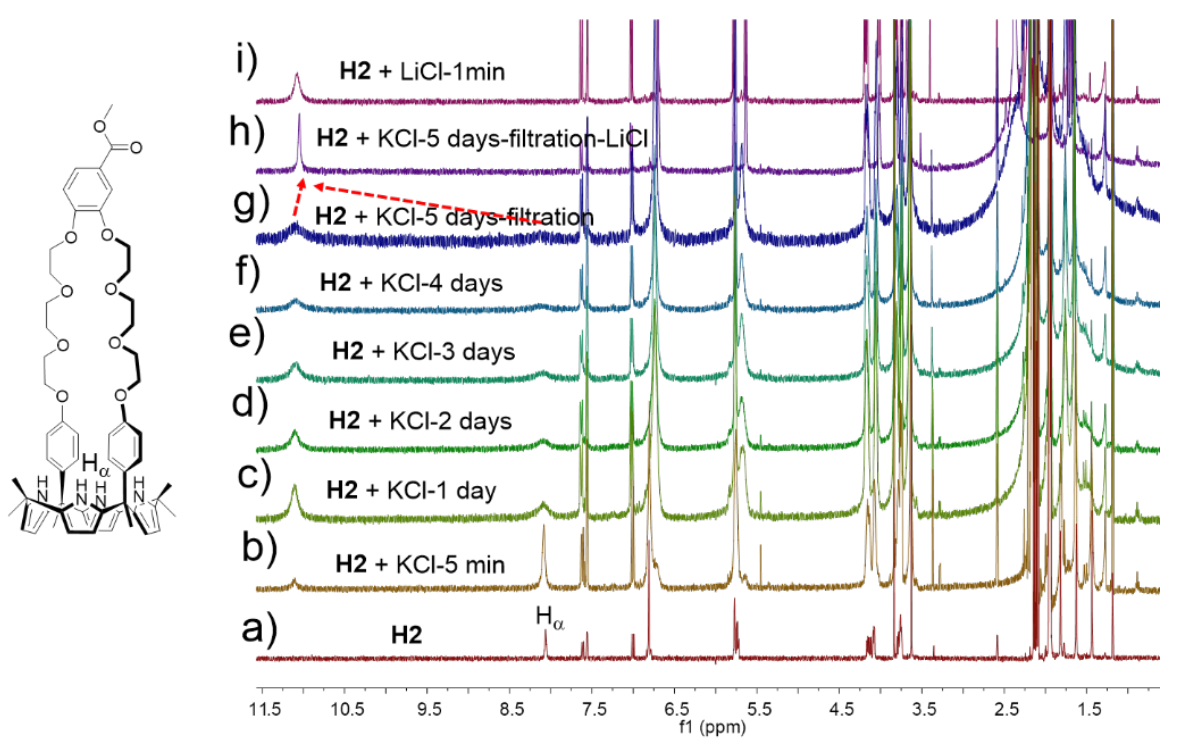

Figure S56. ${ }^{1} \mathrm{H}$ NMR spectra ( $400 \mathrm{MHz}, \mathrm{CD}_{3} \mathrm{CN}, 298 \mathrm{~K}$ ) of a) $5.00 \mathrm{mM}$ solution of $\mathbf{H 2}$; b) $5.00 \mathrm{mM}$ solution of $\mathbf{H 2}$ and 1 equiv of $\mathrm{KCl}$ after mixing for $1 \mathrm{~min}$; c) $5.00 \mathrm{mM}$ solution of $\mathbf{H 2}$ and 1 equiv of $\mathrm{KCl}$ after mixing for 1 day; d) $5.00 \mathrm{mM}$ solution of $\mathbf{H 2}$ and 1 equiv of $\mathrm{KCl}$ after mixing for 2 days; e) $5.00 \mathrm{mM}$ solution of $\mathbf{H 2}$ and 1 equiv of $\mathrm{KCl}$ after mixing for 3 days; f) $5.00 \mathrm{mM}$ solution of $\mathbf{H 2}$ and 1 equiv of $\mathrm{KCl}$ after mixing for 4 days; g) filtered solution of $5.00 \mathrm{mM}$ solution of $\mathbf{H} \mathbf{2}$ and 1 equiv of $\mathrm{KCl}$ after mixing for 5 days; $\mathrm{h}$ ) experiment shown in $\mathrm{g}$ ) after adding 1 equiv of $\mathrm{LiCl}$; i) $5.00 \mathrm{mM}$ solution of $\mathbf{H 2}$ and 1 equiv of $\mathrm{LiCl}$ after mixing for $1 \mathrm{~min}$. 


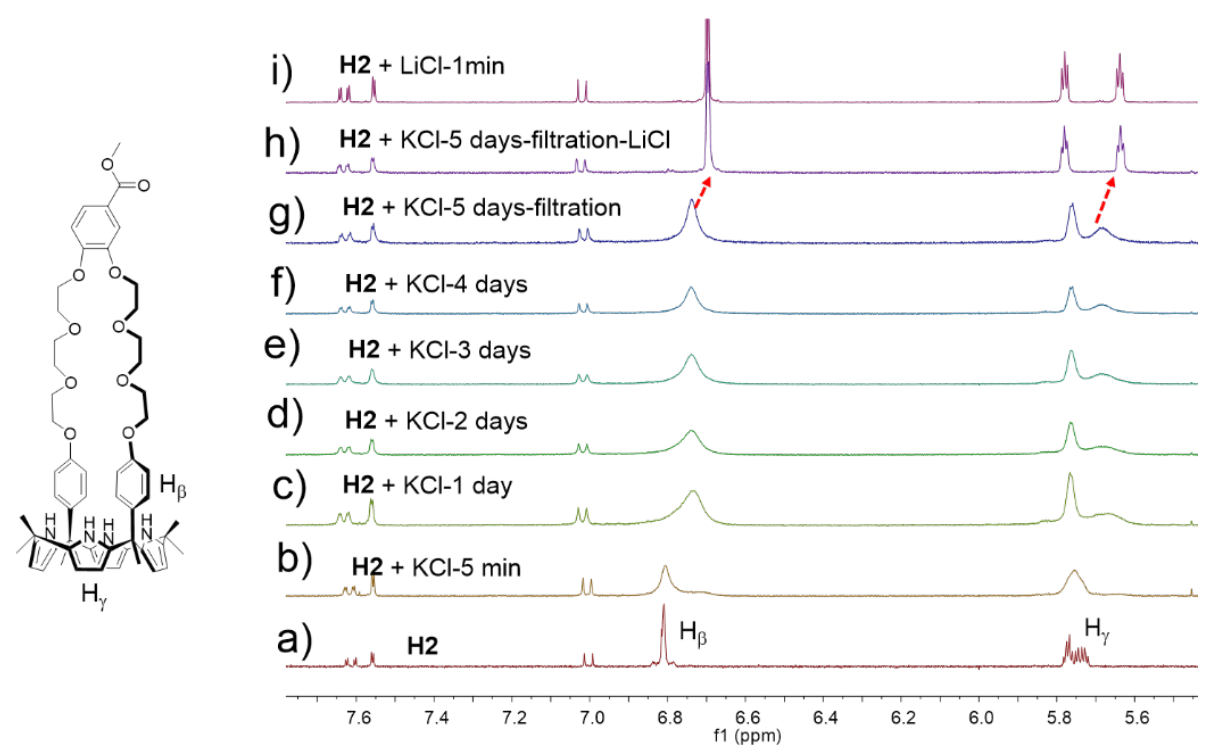

Figure S57. Partial ${ }^{1} \mathrm{H}$ NMR spectra (5.3-7.7) (400 MHz, CD ${ }_{3} \mathrm{CN}, 298 \mathrm{~K}$ ) of a) $5.00 \mathrm{mM}$ solution of H2; b) $5.00 \mathrm{mM}$ solution of $\mathbf{H 2}$ and 1 equiv of $\mathrm{KCl}$ after mixing for $1 \mathrm{~min}$; c) $5.00 \mathrm{mM}$ solution of $\mathbf{H 2}$ and 1 equiv of $\mathrm{KCl}$ after mixing for 1 day; d) $5.00 \mathrm{mM}$ solution of $\mathbf{H 2}$ and 1 equiv of $\mathrm{KCl}$ after mixing for 2 days; e) $5.00 \mathrm{mM}$ solution of $\mathbf{H 2}$ and 1 equiv of $\mathrm{KCl}$ after mixing for 3 days; f) $5.00 \mathrm{mM}$ solution of $\mathbf{H 2}$ and 1 equiv of $\mathrm{KCl}$ after mixing for 4 days; g) filtered solution of $5.00 \mathrm{mM}$ solution of $\mathbf{H} \mathbf{2}$ and 1 equiv of $\mathrm{KCl}$ after mixing for 5 days; h) experiment shown in $\mathrm{g}$ ) after adding 1 equiv of $\mathrm{LiCl}$; i) $5.00 \mathrm{mM}$ solution of $\mathbf{H 2}$ and 1 equiv of $\mathrm{LiCl}$ after mixing for $1 \mathrm{~min}$.

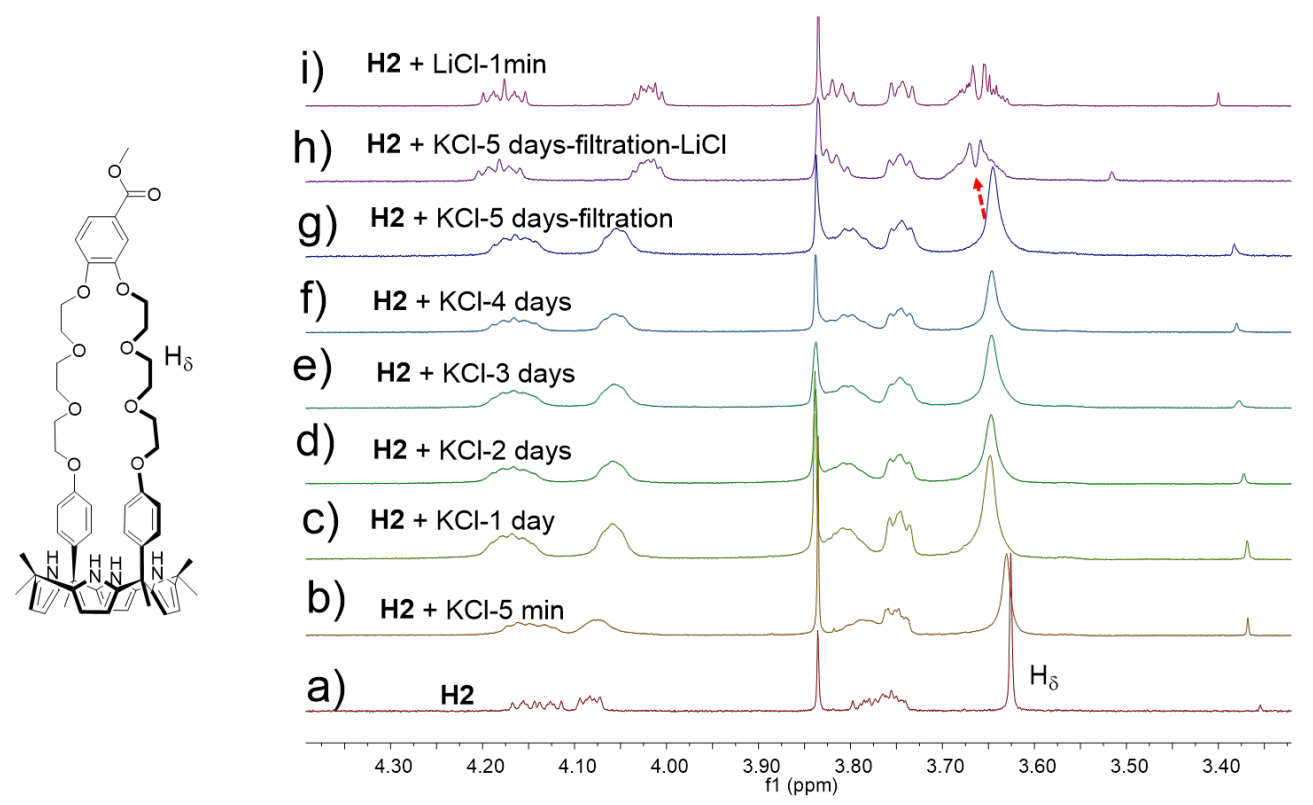

Figure S58. Partial ${ }^{1} \mathrm{H}$ NMR spectra (3.5-4.3) (400 MHz, CD ${ }_{3} \mathrm{CN}, 298 \mathrm{~K}$ ) of a) $5.00 \mathrm{mM}$ solution of H2; b) $5.00 \mathrm{mM}$ solution of $\mathbf{H} 2$ and 1 equiv of $\mathrm{KCl}$ after mixing for $1 \mathrm{~min}$; c) $5.00 \mathrm{mM}$ solution of $\mathbf{H 2}$ and 1 equiv of $\mathrm{KCl}$ after mixing for 1 day; d) $5.00 \mathrm{mM}$ solution of $\mathbf{H 2}$ and 1 equiv of $\mathrm{KCl}$ after mixing for 2 days; e) $5.00 \mathrm{mM}$ solution of $\mathbf{H} \mathbf{2}$ and 1 equiv of $\mathrm{KCl}$ after mixing for 3 days; f) $5.00 \mathrm{mM}$ solution of $\mathbf{H 2}$ and 1 equiv of $\mathrm{KCl}$ after mixing for 4 days; g) filtered solution of $5.00 \mathrm{mM}$ solution of $\mathbf{H 2}$ and 1 equiv of $\mathrm{KCl}$ after mixing for 5 days; h) experiment shown in $\mathrm{g}$ ) after adding 1 equiv of $\mathrm{LiCl}$; i) $5.00 \mathrm{mM}$ solution of $\mathbf{H 2}$ and 1 equiv of $\mathrm{LiCl}$ after mixing for $1 \mathrm{~min}$. 


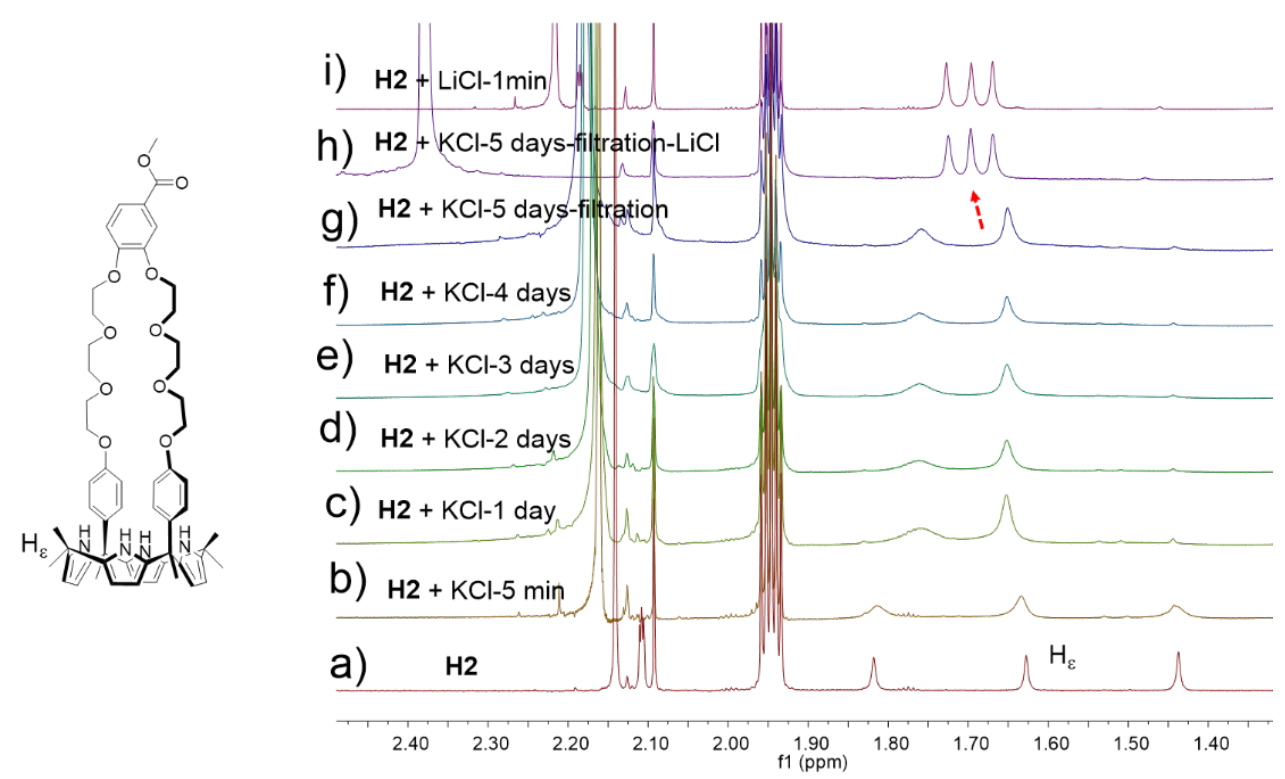

Figure S59. Partial ${ }^{1} \mathrm{H}$ NMR spectra (1.0-2.5) (400 MHz, CD $\left.{ }_{3} \mathrm{CN}, 298 \mathrm{~K}\right)$ of a) $5.00 \mathrm{mM}$ solution of $\mathbf{H 2}$; b) $5.00 \mathrm{mM}$ solution of $\mathbf{H} 2$ and 1 equiv of $\mathrm{KCl}$ after mixing for $1 \mathrm{~min}$; c) $5.00 \mathrm{mM}$ solution of $\mathbf{H 2}$ and 1 equiv of $\mathrm{KCl}$ after mixing for 1 day; d) $5.00 \mathrm{mM}$ solution of $\mathbf{H 2}$ and 1 equiv of $\mathrm{KCl}$ after mixing for 2 days; e) $5.00 \mathrm{mM}$ solution of $\mathbf{H 2}$ and 1 equiv of $\mathrm{KCl}$ after mixing for 3 days; f) $5.00 \mathrm{mM}$ solution of $\mathbf{H 2}$ and 1 equiv of $\mathrm{KCl}$ after mixing for 4 days; g) filtered solution of $5.00 \mathrm{mM}$ solution of $\mathbf{H} \mathbf{2}$ and 1 equiv of $\mathrm{KCl}$ after mixing for 5 days; h) experiment shown in $\mathrm{g}$ ) after adding 1 equiv of $\mathrm{LiCl}$; i) $5.00 \mathrm{mM}$ solution of $\mathbf{H 2}$ and 1 equiv of $\mathrm{LiCl}$ after mixing for $1 \mathrm{~min}$.

\subsection{Competition between $\mathbf{H} 2 \mathrm{JiCl}$ and $\boldsymbol{H} \mathbf{2} \mathrm{MgCl}_{2}$}

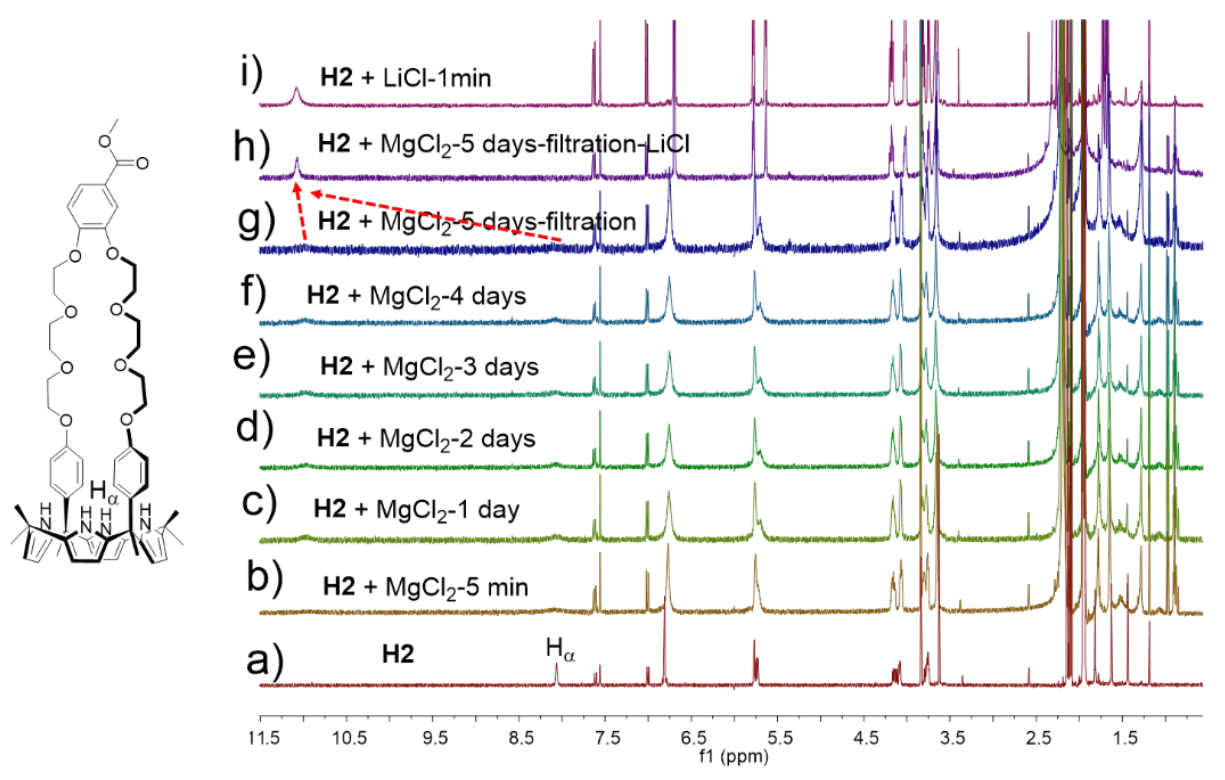

Figure S60. ${ }^{1} \mathrm{H}$ NMR spectra ( $400 \mathrm{MHz}, \mathrm{CD}_{3} \mathrm{CN}, 298 \mathrm{~K}$ ) of a) $5.00 \mathrm{mM}$ solution of $\mathbf{H 2}$; b) $5.00 \mathrm{mM}$ solution of $\mathbf{H 2}$ and 1 equiv of $\mathrm{MgCl}_{2}$ after mixing for $1 \mathrm{~min}$; c) $5.00 \mathrm{mM}$ solution of $\mathbf{H 2}$ and 1 equiv of $\mathrm{MgCl}_{2}$ after mixing for 1 day; d) $5.00 \mathrm{mM}$ solution of $\mathbf{H 2}$ and 1 equiv of $\mathrm{MgCl}_{2}$ after mixing for 2 days; e) $5.00 \mathrm{mM}$ solution of $\mathbf{H 2}$ and 1 equiv of $\mathrm{MgCl}_{2}$ after mixing for 3 days; f) $5.00 \mathrm{mM}$ solution of $\mathbf{H 2}$ and 1 equiv of $\mathrm{MgCl}_{2}$ after mixing for 4 days; $\mathrm{g}$ ) filtered solution of $5.00 \mathrm{mM}$ solution of $\mathbf{H 2}$ and 1 equiv of $\mathrm{MgCl}_{2}$ after mixing for 5 days; h) experiment shown in g) after adding 1 equiv of $\mathrm{LiCl}$; i) $5.00 \mathrm{mM}$ solution of $\mathbf{H} 2$ and 1 equiv of $\mathrm{LiCl}$ after mixing for $1 \mathrm{~min}$. 


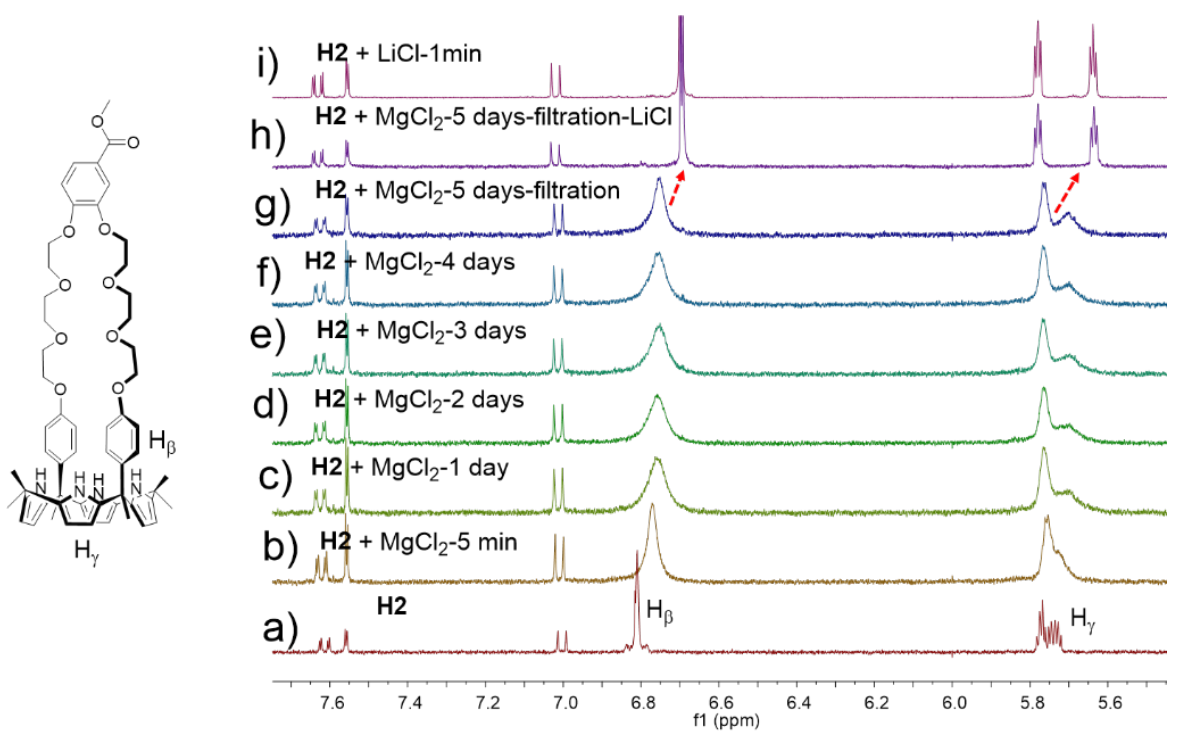

Figure S61. Partial ${ }^{1} \mathrm{H}$ NMR spectra (5.3-7.7) (400 MHz, CD $\left.{ }_{3} \mathrm{CN}, 298 \mathrm{~K}\right)$ of a) $5.00 \mathrm{mM}$ solution of $\mathbf{H 2}$; b) $5.00 \mathrm{mM}$ solution of $\mathbf{H 2}$ and 1 equiv of $\mathrm{MgCl}_{2}$ after mixing for $1 \mathrm{~min}$; c) $5.00 \mathrm{mM}$ solution of $\mathbf{H 2}$ and 1 equiv of $\mathrm{MgCl}_{2}$ after mixing for 1 day; d) $5.00 \mathrm{mM}$ solution of $\mathbf{H 2}$ and 1 equiv of $\mathrm{MgCl}_{2}$ after mixing for 2 days; e) $5.00 \mathrm{mM}$ solution of $\mathbf{H 2}$ and 1 equiv of $\mathrm{MgCl}_{2}$ after mixing for 3 days; f) $5.00 \mathrm{mM}$ solution of $\mathbf{H 2}$ and 1 equiv of $\mathrm{MgCl}_{2}$ after mixing for 4 days; g) filtered solution of $5.00 \mathrm{mM}$ solution of $\mathbf{H 2}$ and 1 equiv of $\mathrm{MgCl}_{2}$ after mixing for 5 days; h) experiment shown in $\mathrm{g}$ ) after adding 1 equiv of $\mathrm{LiCl}$; i) $5.00 \mathrm{mM}$ solution of $\mathbf{H 2}$ and 1 equiv of $\mathrm{LiCl}$ after mixing for $1 \mathrm{~min}$.

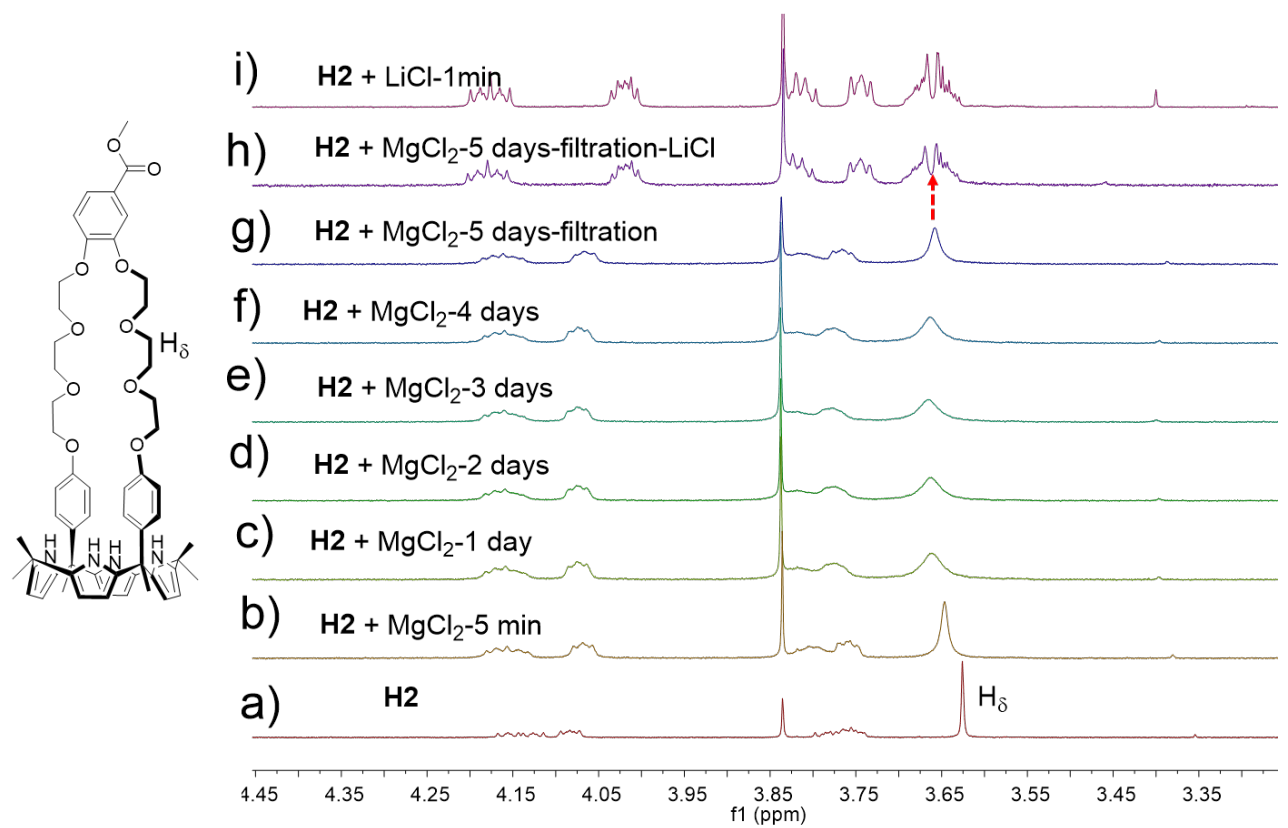

Figure S62. Partial ${ }^{1} \mathrm{H}$ NMR spectra (3.5-4.3) (400 MHz, CD 3 CN, $\left.298 \mathrm{~K}\right)$ of a) $5.00 \mathrm{mM}$ solution of H2; b) $5.00 \mathrm{mM}$ solution of $\mathbf{H 2}$ and 1 equiv of $\mathrm{MgCl}_{2}$ after mixing for $1 \mathrm{~min}$; c) $5.00 \mathrm{mM}$ solution of $\mathbf{H 2}$ and 1 equiv of $\mathrm{MgCl}_{2}$ after mixing for 1 day; d) $5.00 \mathrm{mM}$ solution of $\mathbf{H 2}$ and 1 equiv of $\mathrm{MgCl}_{2}$ after mixing for 2 days; e) $5.00 \mathrm{mM}$ solution of $\mathbf{H 2}$ and 1 equiv of $\mathrm{MgCl}_{2}$ after mixing for 3 days; f) $5.00 \mathrm{mM}$ solution of $\mathbf{H 2}$ and 1 equiv of $\mathrm{MgCl}_{2}$ after mixing for 4 days; g) filtered solution of $5.00 \mathrm{mM}$ solution of $\mathbf{H 2}$ and 1 equiv of $\mathrm{MgCl}_{2}$ after mixing for 5 days; h) experiment shown in $\mathrm{g}$ ) after adding 1 equiv of $\mathrm{LiCl}$; i) $5.00 \mathrm{mM}$ solution of $\mathbf{H 2}$ and 1 equiv of $\mathrm{LiCl}$ after mixing for $1 \mathrm{~min}$. 


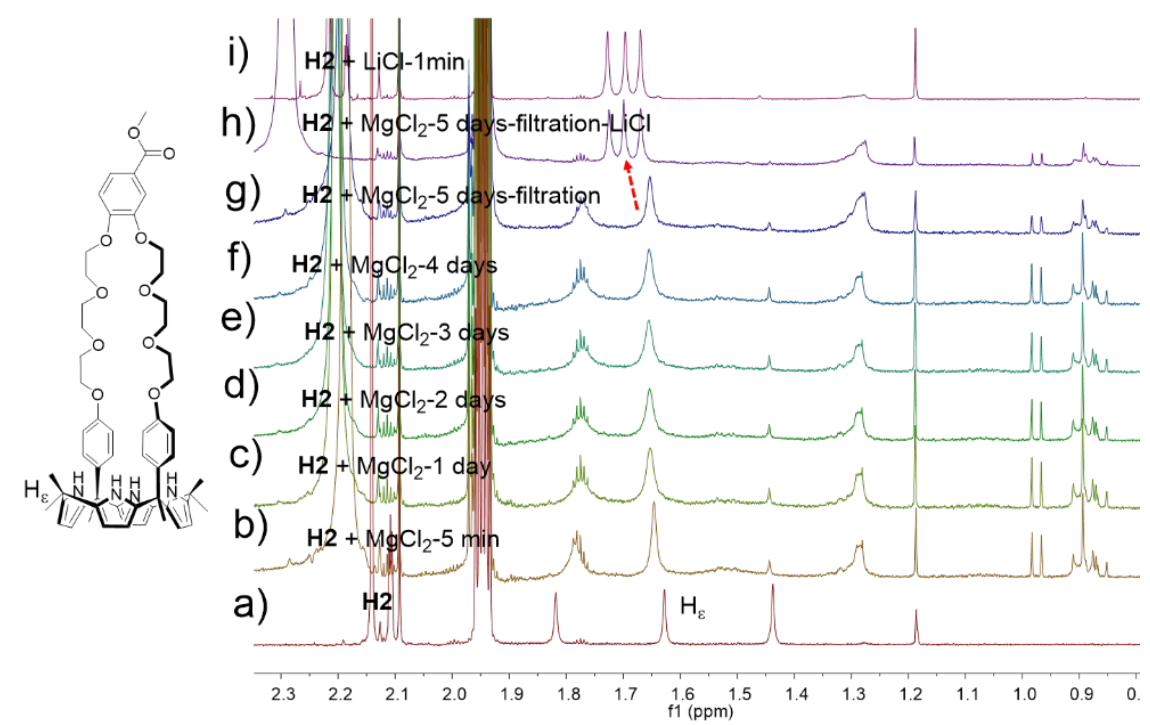

Figure S63. Partial ${ }^{1} \mathrm{H}$ NMR spectra (1.0-2.5) (400 MHz, $\left.\mathrm{CD}_{3} \mathrm{CN}, 298 \mathrm{~K}\right)$ of a) $5.00 \mathrm{mM}$ solution of H2; b) $5.00 \mathrm{mM}$ solution of $\mathbf{H 2}$ and 1 equiv of $\mathrm{MgCl}_{2}$ after mixing for $1 \mathrm{~min}$; c) $5.00 \mathrm{mM}$ solution of $\mathbf{H 2}$ and 1 equiv of $\mathrm{MgCl}_{2}$ after mixing for 1 day; d) $5.00 \mathrm{mM}$ solution of $\mathbf{H 2}$ and 1 equiv of $\mathrm{MgCl}_{2}$ after mixing for 2 days; e) $5.00 \mathrm{mM}$ solution of $\mathbf{H 2}$ and 1 equiv of $\mathrm{MgCl}_{2}$ after mixing for 3 days; f) $5.00 \mathrm{mM}$ solution of $\mathbf{H 2}$ and 1 equiv of $\mathrm{MgCl}_{2}$ after mixing for 4 days; g) filtered solution of $5.00 \mathrm{mM}$ solution of $\mathbf{H 2}$ and 1 equiv of $\mathrm{MgCl}_{2}$ after mixing for 5 days; h) experiment shown in g) after adding 1 equiv of $\mathrm{LiCl}$; i) $5.00 \mathrm{mM}$ solution of $\mathbf{H 2}$ and 1 equiv of $\mathrm{LiCl}$ after mixing for $1 \mathrm{~min}$.

\subsection{Competition between $\boldsymbol{H} 2 \supset \mathrm{LiCl}$ and $\boldsymbol{H} 2 \supset \mathrm{CaCl}_{2}$}

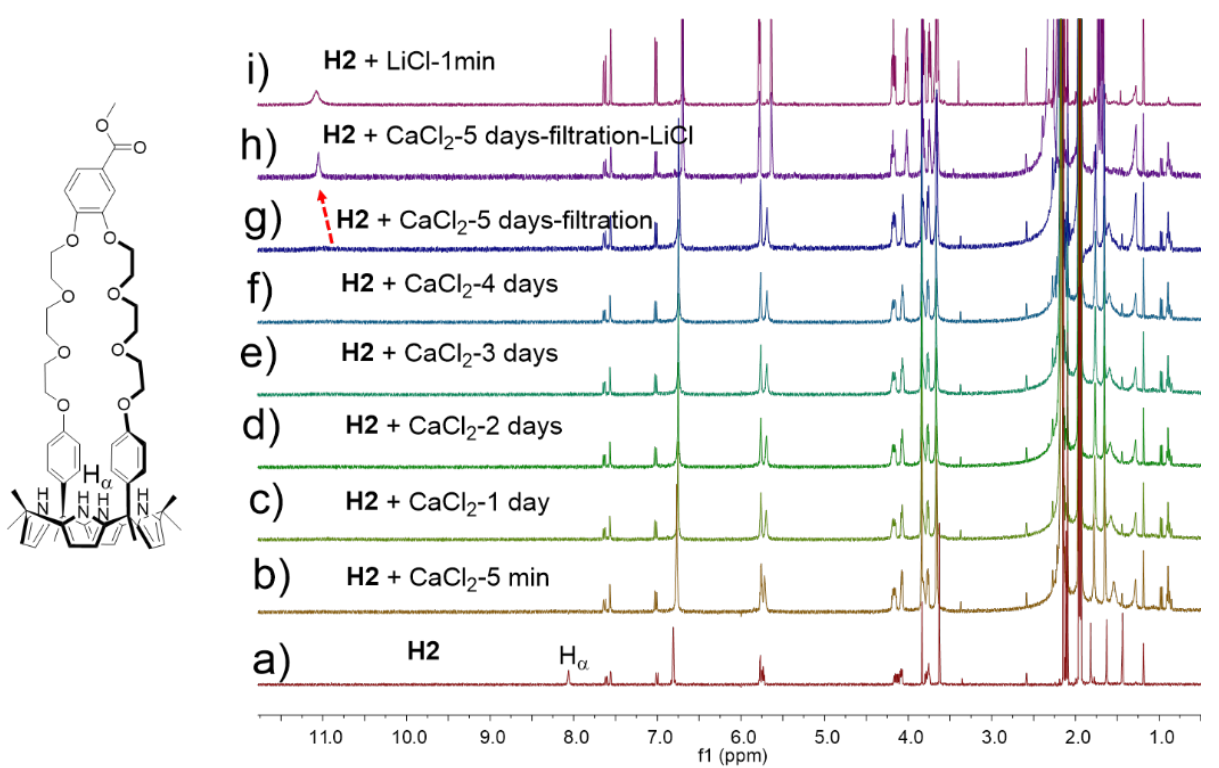

Figure S64. ${ }^{1} \mathrm{H}$ NMR spectra (400 MHz, $\mathrm{CD}_{3} \mathrm{CN}, 298 \mathrm{~K}$ ) of a) $5.00 \mathrm{mM}$ solution of $\mathbf{H 2}$; b) $5.00 \mathrm{mM}$ solution of $\mathbf{H 2}$ and 1 equiv of $\mathrm{CaCl}_{2}$ after mixing for $1 \mathrm{~min}$; c) $5.00 \mathrm{mM}$ solution of $\mathbf{H 2}$ and 1 equiv of $\mathrm{CaCl}_{2}$ after mixing for 1 day; d) $5.00 \mathrm{mM}$ solution of $\mathbf{H 2}$ and 1 equiv of $\mathrm{CaCl}_{2}$ after mixing for 2 days; e) $5.00 \mathrm{mM}$ solution of $\mathbf{H 2}$ and 1 equiv of $\mathrm{CaCl}_{2}$ after mixing for 3 days; f) $5.00 \mathrm{mM}$ solution of $\mathbf{H 2}$ and 1 equiv of $\mathrm{CaCl}_{2}$ after mixing for 4 days; g) filtered solution of $5.00 \mathrm{mM}$ solution of $\mathbf{H 2}$ and 1 equiv of $\mathrm{CaCl}_{2}$ after mixing for 5 days; h) experiment shown in g) after adding 1 equiv of $\mathrm{LiCl}$; i) $5.00 \mathrm{mM}$ solution of $\mathbf{H 2}$ and 1 equiv of $\mathrm{LiCl}$ after mixing for $1 \mathrm{~min}$. 


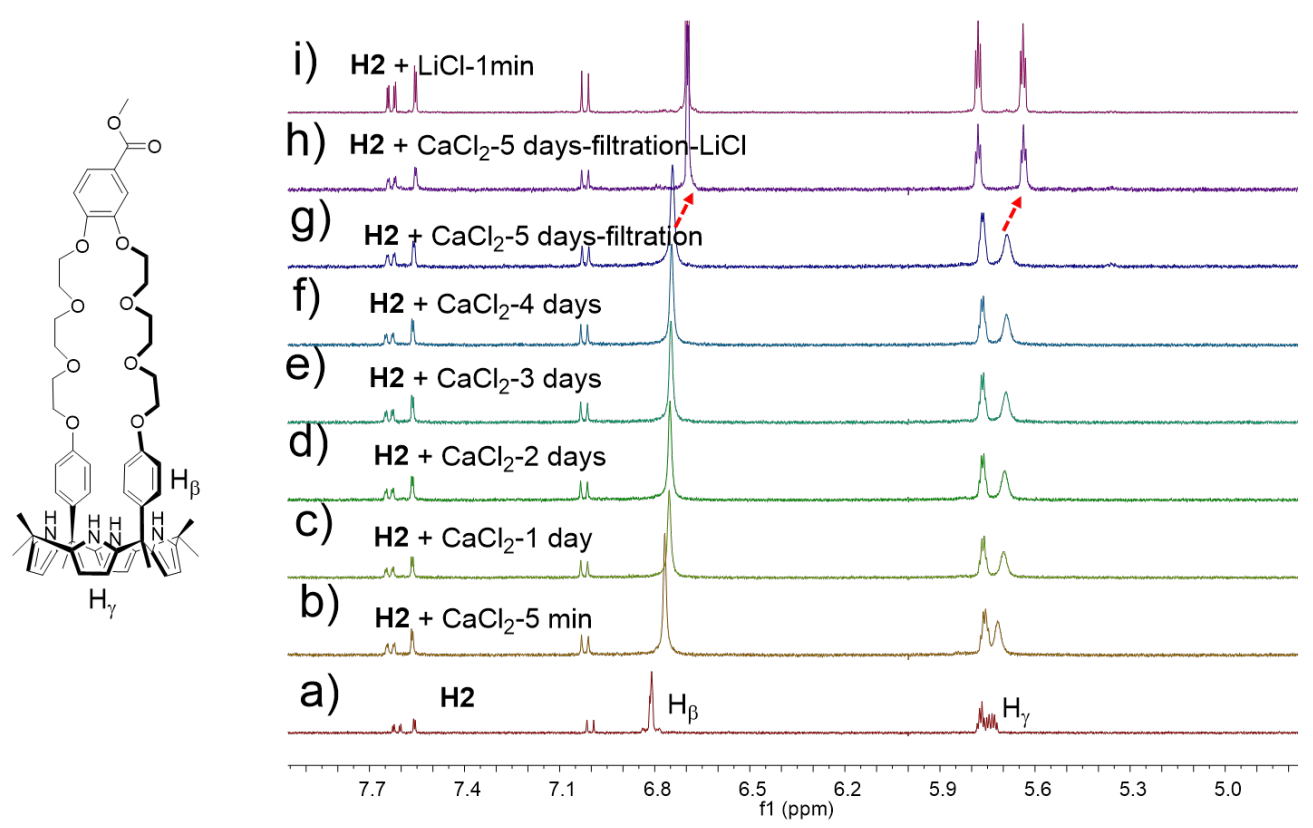

Figure S65. Partial ${ }^{1} \mathrm{H}$ NMR spectra (5.3-7.7) (400 MHz, $\left.\mathrm{CD}_{3} \mathrm{CN}, 298 \mathrm{~K}\right)$ of a) $5.00 \mathrm{mM}$ solution of H2; b) $5.00 \mathrm{mM}$ solution of $\mathbf{H 2}$ and 1 equiv of $\mathrm{CaCl}_{2}$ after mixing for $1 \mathrm{~min}$; c) $5.00 \mathrm{mM}$ solution of $\mathbf{H 2}$ and 1 equiv of $\mathrm{CaCl}_{2}$ after mixing for 1 day; d) $5.00 \mathrm{mM}$ solution of $\mathbf{H 2}$ and 1 equiv of $\mathrm{CaCl}_{2}$ after mixing for 2 days; e) $5.00 \mathrm{mM}$ solution of $\mathbf{H 2}$ and 1 equiv of $\mathrm{CaCl}_{2}$ after mixing for 3 days; f) $5.00 \mathrm{mM}$ solution of $\mathbf{H 2}$ and 1 equiv of $\mathrm{CaCl}_{2}$ after mixing for 4 days; g) filtered solution of $5.00 \mathrm{mM}$ solution of $\mathbf{H 2}$ and 1 equiv of $\mathrm{CaCl}_{2}$ after mixing for 5 days; h) experiment shown in g) after adding 1 equiv of $\mathrm{LiCl}$; i) $5.00 \mathrm{mM}$ solution of $\mathbf{H 2}$ and 1 equiv of $\mathrm{LiCl}$ after mixing for $1 \mathrm{~min}$.

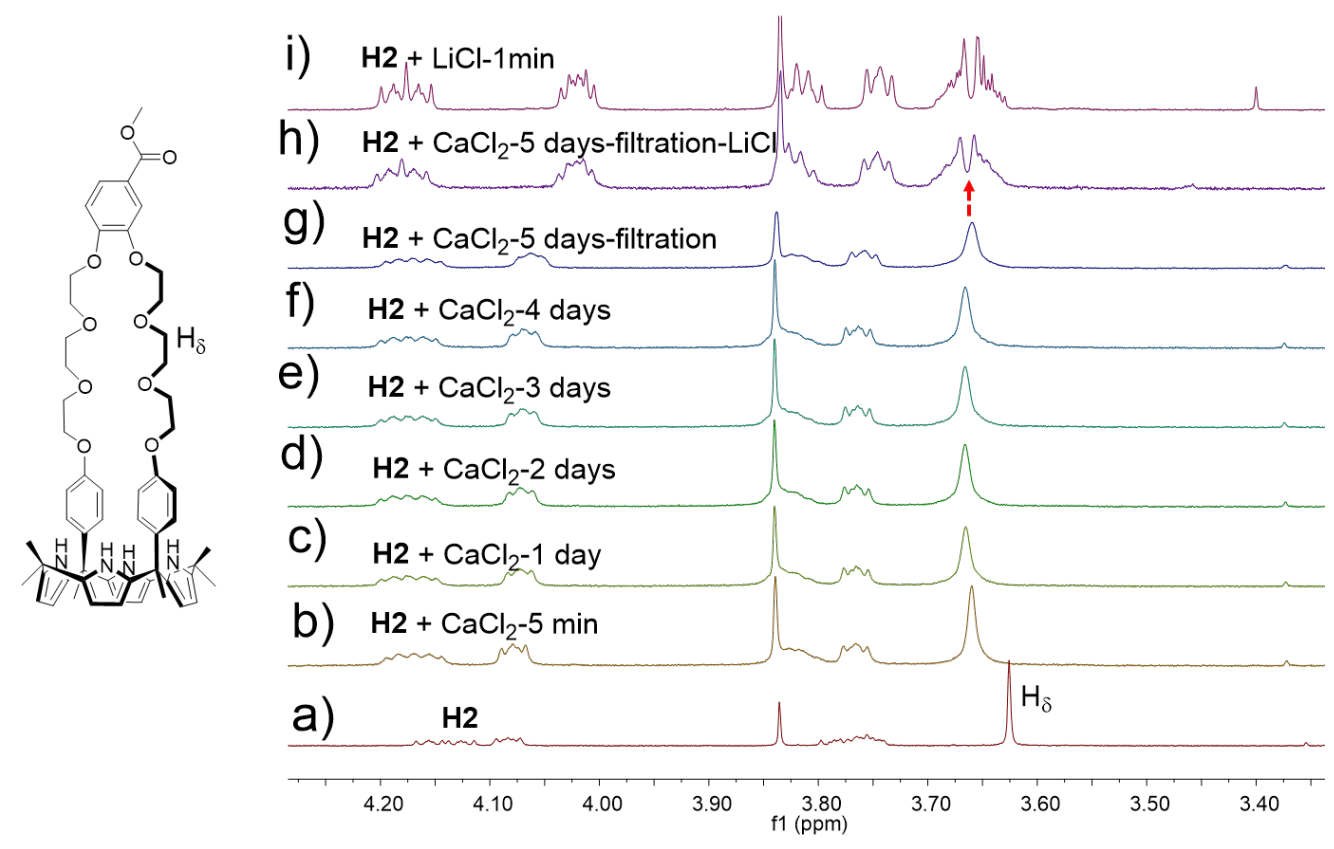

Figure S66. Partial ${ }^{1} \mathrm{H}$ NMR spectra (3.5-4.3) (400 MHz, CD $\left.{ }_{3} \mathrm{CN}, 298 \mathrm{~K}\right)$ of a) $5.00 \mathrm{mM}$ solution of H2; b) $5.00 \mathrm{mM}$ solution of $\mathbf{H 2}$ and 1 equiv of $\mathrm{CaCl}_{2}$ after mixing for $1 \mathrm{~min}$; c) $5.00 \mathrm{mM}$ solution of $\mathbf{H} 2$ and 1 equiv of $\mathrm{CaCl}_{2}$ after mixing for 1 day; d) $5.00 \mathrm{mM}$ solution of $\mathbf{H 2}$ and 1 equiv of $\mathrm{CaCl}_{2}$ after mixing for 2 days; e) $5.00 \mathrm{mM}$ solution of $\mathbf{H 2}$ and 1 equiv of $\mathrm{CaCl}_{2}$ after mixing for 3 days; f) $5.00 \mathrm{mM}$ solution of $\mathbf{H 2}$ and 1 equiv of $\mathrm{CaCl}_{2}$ after mixing for 4 days; g) filtered solution of $5.00 \mathrm{mM}$ solution of $\mathbf{H 2}$ and 1 equiv of $\mathrm{CaCl}_{2}$ after mixing for 5 days; h) experiment shown in $\mathrm{g}$ ) after adding 1 equiv of $\mathrm{LiCl}$; i) $5.00 \mathrm{mM}$ solution of $\mathbf{H 2}$ and 1 equiv of $\mathrm{LiCl}$ after mixing for $1 \mathrm{~min}$. 


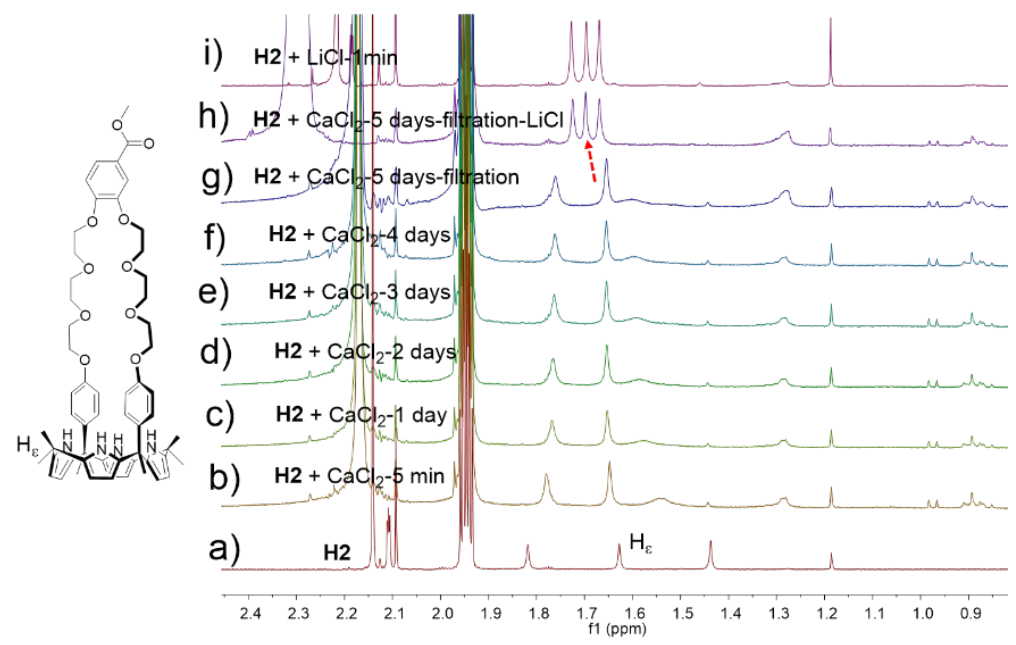

Figure S67. Partial ${ }^{1} \mathrm{H}$ NMR spectra (1.0-2.5) $\left(400 \mathrm{MHz}, \mathrm{CD}_{3} \mathrm{CN}, 298 \mathrm{~K}\right)$ of a) $5.00 \mathrm{mM}$ solution of $\mathbf{H 2}$; b) $5.00 \mathrm{mM}$ solution of $\mathbf{H 2}$ and 1 equiv of $\mathrm{CaCl}_{2}$ after mixing for $1 \mathrm{~min}$; c) $5.00 \mathrm{mM}$ solution of $\mathbf{H 2}$ and 1 equiv of $\mathrm{CaCl}_{2}$ after mixing for 1 day; d) $5.00 \mathrm{mM}$ solution of $\mathbf{H 2}$ and 1 equiv of $\mathrm{CaCl}_{2}$ after mixing for 2 days; e) $5.00 \mathrm{mM}$ solution of $\mathbf{H 2}$ and 1 equiv of $\mathrm{CaCl}_{2}$ after mixing for 3 days; f) $5.00 \mathrm{mM}$ solution of $\mathbf{H 2}$ and 1 equiv of $\mathrm{CaCl}_{2}$ after mixing for 4 days; g) filtered solution of $5.00 \mathrm{mM}$ solution of $\mathbf{H 2}$ and 1 equiv of $\mathrm{CaCl}_{2}$ after mixing for 5 days; h) experiment shown in $\mathrm{g}$ ) after adding 1 equiv of $\mathrm{LiCl}$; i) $5.00 \mathrm{mM}$ solution of $\mathbf{H 2}$ and 1 equiv of $\mathrm{LiCl}$ after mixing for $1 \mathrm{~min}$.

9.6 Complexation between $\mathbf{H} 2$ and mixture of $\mathrm{LiCl}, \mathrm{NaCl}, \mathrm{KCl}, \mathrm{MgCl}_{2}$ and $\mathrm{CaCl}_{2}$

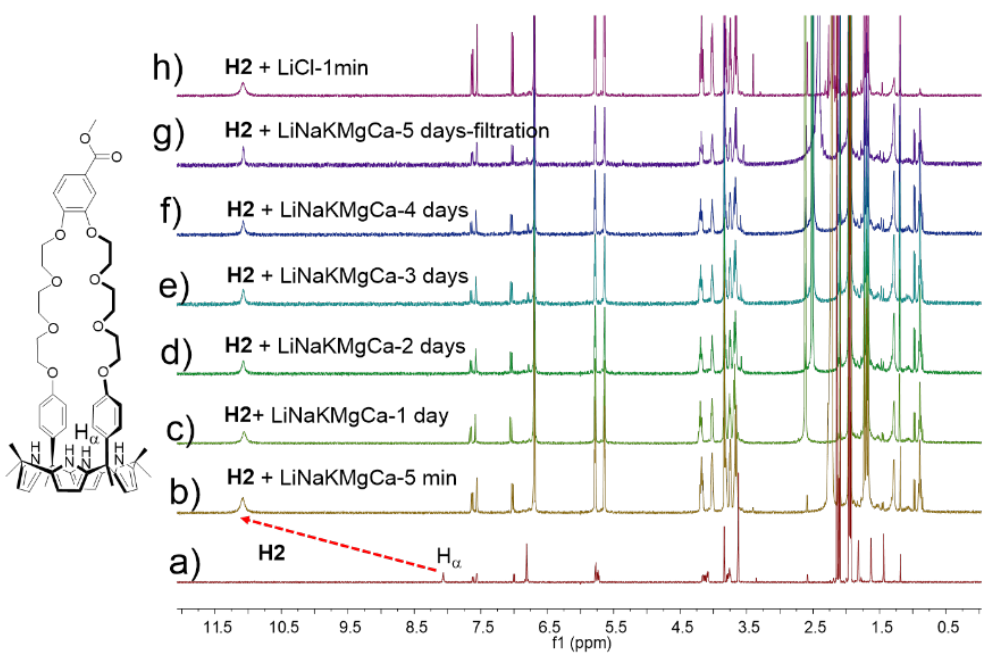

Figure S68. ${ }^{1} \mathrm{H}$ NMR spectra (400 MHz, $\mathrm{CD}_{3} \mathrm{CN}, 298 \mathrm{~K}$ ) of a) $5.00 \mathrm{mM}$ solution of $\mathbf{H 2}$; b) $5.00 \mathrm{mM}$ solution of $\mathbf{H 2}$ and 1 equiv of five salts $\left(\mathrm{LiCl}, \mathrm{NaCl}, \mathrm{KCl}, \mathrm{MgCl}_{2}\right.$ and $\left.\mathrm{CaCl}_{2}\right)$ after mixing for $1 \mathrm{~min}$; c) $5.00 \mathrm{mM}$ solution of $\mathbf{H 2}$ and 1 equiv of five salts ( $\mathrm{LiCl}, \mathrm{NaCl}, \mathrm{KCl}, \mathrm{MgCl}_{2}$ and $\mathrm{CaCl}_{2}$ ) after mixing for 1 day; d) $5.00 \mathrm{mM}$ solution of $\mathbf{H 2}$ and 1 equiv of five salts ( $\mathrm{LiCl}, \mathrm{NaCl}, \mathrm{KCl}, \mathrm{MgCl}_{2}$ and $\mathrm{CaCl}_{2}$ ) after mixing for 2 days; e) $5.00 \mathrm{mM}$ solution of $\mathbf{H 2}$ and 1 equiv of five salts ( $\mathrm{LiCl}, \mathrm{NaCl}, \mathrm{KCl}, \mathrm{MgCl}_{2}$ and $\mathrm{CaCl}_{2}$ ) after mixing for 3 days; f) $5.00 \mathrm{mM}$ solution of $\mathbf{H 2}$ and 1 equiv of five salts ( $\mathrm{LiCl}, \mathrm{NaCl}, \mathrm{KCl}, \mathrm{MgCl}_{2}$ and $\mathrm{CaCl}_{2}$ ) after mixing for 4 days; $\mathrm{g}$ ) filtered $5.00 \mathrm{mM}$ solution of $\mathbf{H 2}$ and 1 equiv of five salts $\left(\mathrm{LiCl}, \mathrm{NaCl}, \mathrm{KCl}, \mathrm{MgCl}_{2}\right.$ and $\mathrm{CaCl}_{2}$ ) after mixing for after mixing for 5 days; h) $5.00 \mathrm{mM}$ solution of $\mathbf{H 2}$ and 1 equiv of $\mathrm{LiCl}$ after mixing for $1 \mathrm{~min}$. 


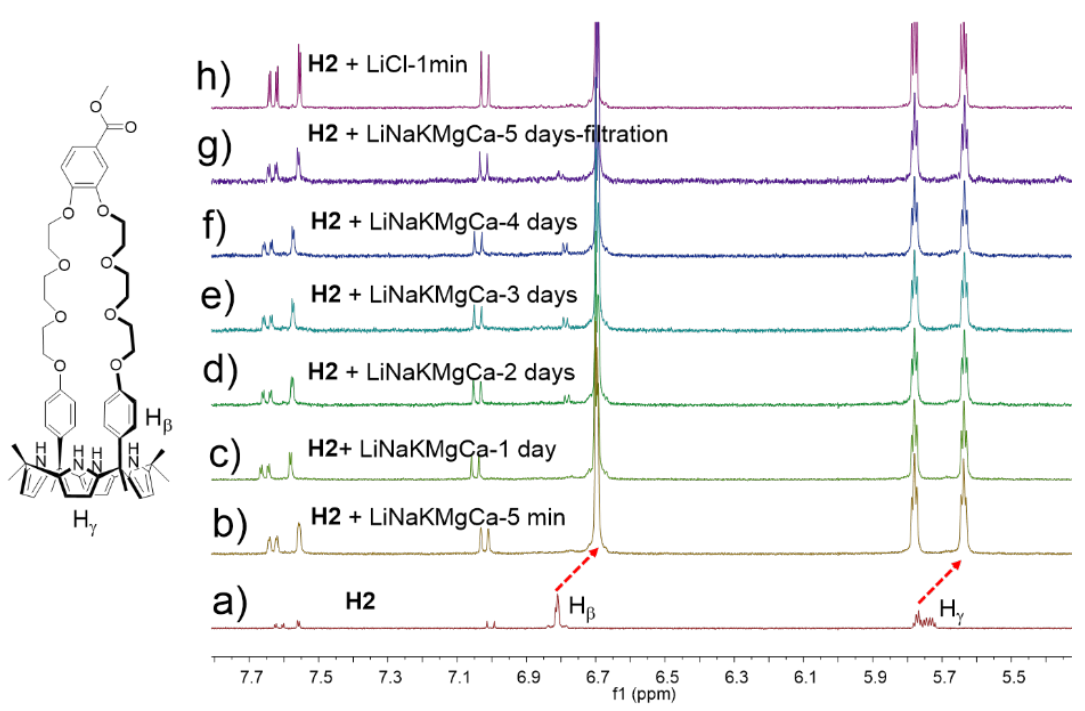

Figure S69. Partial ${ }^{1} \mathrm{H}$ NMR spectra (5.3-7.7) $\left(400 \mathrm{MHz}, \mathrm{CD}_{3} \mathrm{CN}, 298 \mathrm{~K}\right)$ of a) $5.00 \mathrm{mM}$ solution of H2; b) $5.00 \mathrm{mM}$ solution of $\mathbf{H 2}$ and 1 equiv of five salts ( $\mathrm{LiCl}, \mathrm{NaCl}, \mathrm{KCl}, \mathrm{MgCl}_{2}$ and $\mathrm{CaCl}_{2}$ ) after mixing for $1 \mathrm{~min}$; c) $5.00 \mathrm{mM}$ solution of $\mathbf{H 2}$ and 1 equiv of five salts $\left(\mathrm{LiCl}, \mathrm{NaCl}, \mathrm{KCl}, \mathrm{MgCl}_{2}\right.$ and $\mathrm{CaCl}_{2}$ ) after mixing for 1 day; d) $5.00 \mathrm{mM}$ solution of $\mathbf{H 2}$ and 1 equiv of five salts $\left(\mathrm{LiCl}, \mathrm{NaCl}, \mathrm{KCl}, \mathrm{MgCl}_{2}\right.$ and $\mathrm{CaCl}_{2}$ ) after mixing for 2 days; e) $5.00 \mathrm{mM}$ solution of $\mathbf{H 2}$ and 1 equiv of five salts $\left(\mathrm{LiCl}, \mathrm{NaCl}, \mathrm{KCl}, \mathrm{MgCl}_{2}\right.$ and $\left.\mathrm{CaCl}_{2}\right)$ after mixing for 3 days; f) $5.00 \mathrm{mM}$ solution of $\mathbf{H 2}$ and 1 equiv of five salts ( $\mathrm{LiCl}, \mathrm{NaCl}, \mathrm{KCl}, \mathrm{MgCl}_{2}$ and $\left.\mathrm{CaCl}_{2}\right)$ after mixing for 4 days; $\mathrm{g}$ ) filtered 5.00 $\mathrm{mM}$ solution of $\mathbf{H} 2$ and 1 equiv of five salts $\left(\mathrm{LiCl}, \mathrm{NaCl}, \mathrm{KCl}, \mathrm{MgCl}_{2}\right.$ and $\left.\mathrm{CaCl}_{2}\right)$ after mixing for after mixing for 5 days; h) $5.00 \mathrm{mM}$ solution of $\mathbf{H} \mathbf{2}$ and 1 equiv of $\mathrm{LiCl}$ after mixing for $1 \mathrm{~min}$.

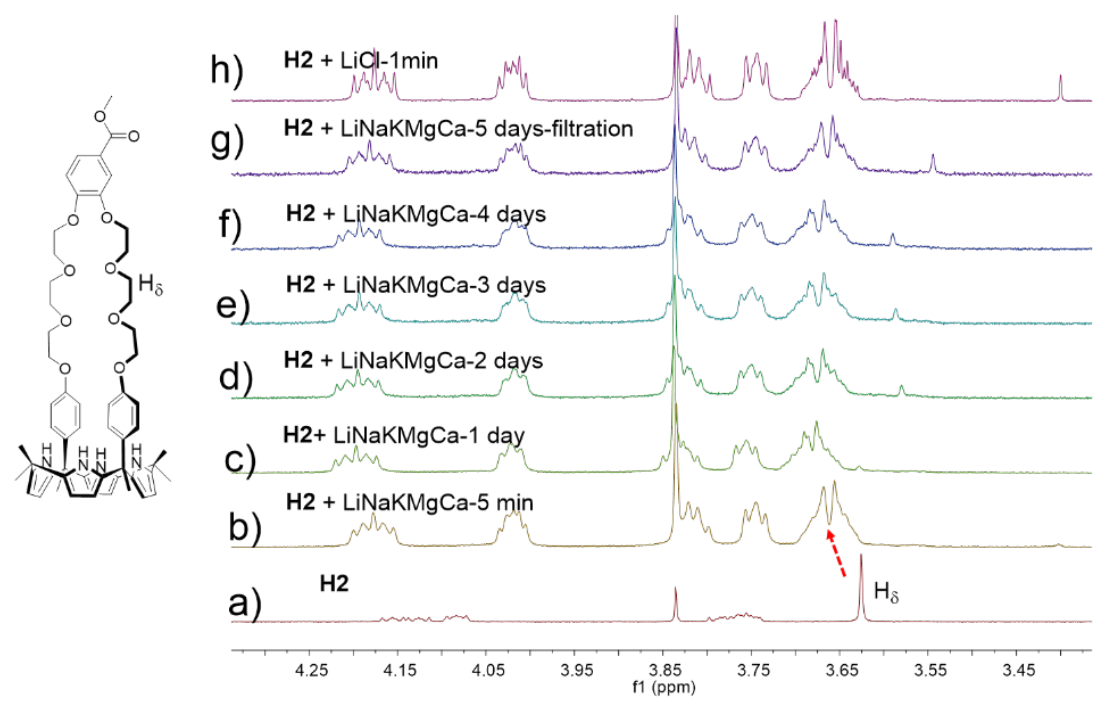

Figure S70. Partial ${ }^{1} \mathrm{H}$ NMR spectra (3.5-4.3) (400 MHz, $\left.\mathrm{CD}_{3} \mathrm{CN}, 298 \mathrm{~K}\right)$ of a) $5.00 \mathrm{mM}$ solution of $\mathbf{H 2}$; b) $5.00 \mathrm{mM}$ solution of $\mathbf{H 2}$ and 1 equiv of five salts ( $\mathrm{LiCl}, \mathrm{NaCl}, \mathrm{KCl}, \mathrm{MgCl}_{2}$ and $\mathrm{CaCl}_{2}$ ) after mixing for $1 \mathrm{~min}$; c) $5.00 \mathrm{mM}$ solution of $\mathbf{H 2}$ and 1 equiv of five salts ( $\mathrm{LiCl}, \mathrm{NaCl}, \mathrm{KCl}, \mathrm{MgCl}_{2}$ and $\mathrm{CaCl}_{2}$ ) after mixing for 1 day; d) $5.00 \mathrm{mM}$ solution of $\mathbf{H 2}$ and 1 equiv of five salts ( $\mathrm{LiCl}, \mathrm{NaCl}, \mathrm{KCl}, \mathrm{MgCl}_{2}$ and $\mathrm{CaCl}_{2}$ ) after mixing for 2 days; e) $5.00 \mathrm{mM}$ solution of $\mathbf{H 2}$ and 1 equiv of five salts ( $\mathrm{LiCl}, \mathrm{NaCl}, \mathrm{KCl}, \mathrm{MgCl}_{2}$ and $\mathrm{CaCl}_{2}$ ) after mixing for 3 days; f) $5.00 \mathrm{mM}$ solution of $\mathbf{H 2}$ and 1 equiv of five salts $\left(\mathrm{LiCl}, \mathrm{NaCl}, \mathrm{KCl}, \mathrm{MgCl}_{2}\right.$ and $\mathrm{CaCl}_{2}$ ) after mixing for 4 days; $\mathrm{g}$ ) filtered 5.00 $\mathrm{mM}$ solution of $\mathbf{H} 2$ and 1 equiv of five salts ( $\mathrm{LiCl}, \mathrm{NaCl}, \mathrm{KCl}, \mathrm{MgCl}_{2}$ and $\mathrm{CaCl}_{2}$ ) after mixing for after mixing for 5 days; h) $5.00 \mathrm{mM}$ solution of $\mathbf{H 2}$ and 1 equiv of $\mathrm{LiCl}$ after mixing for $1 \mathrm{~min}$. 


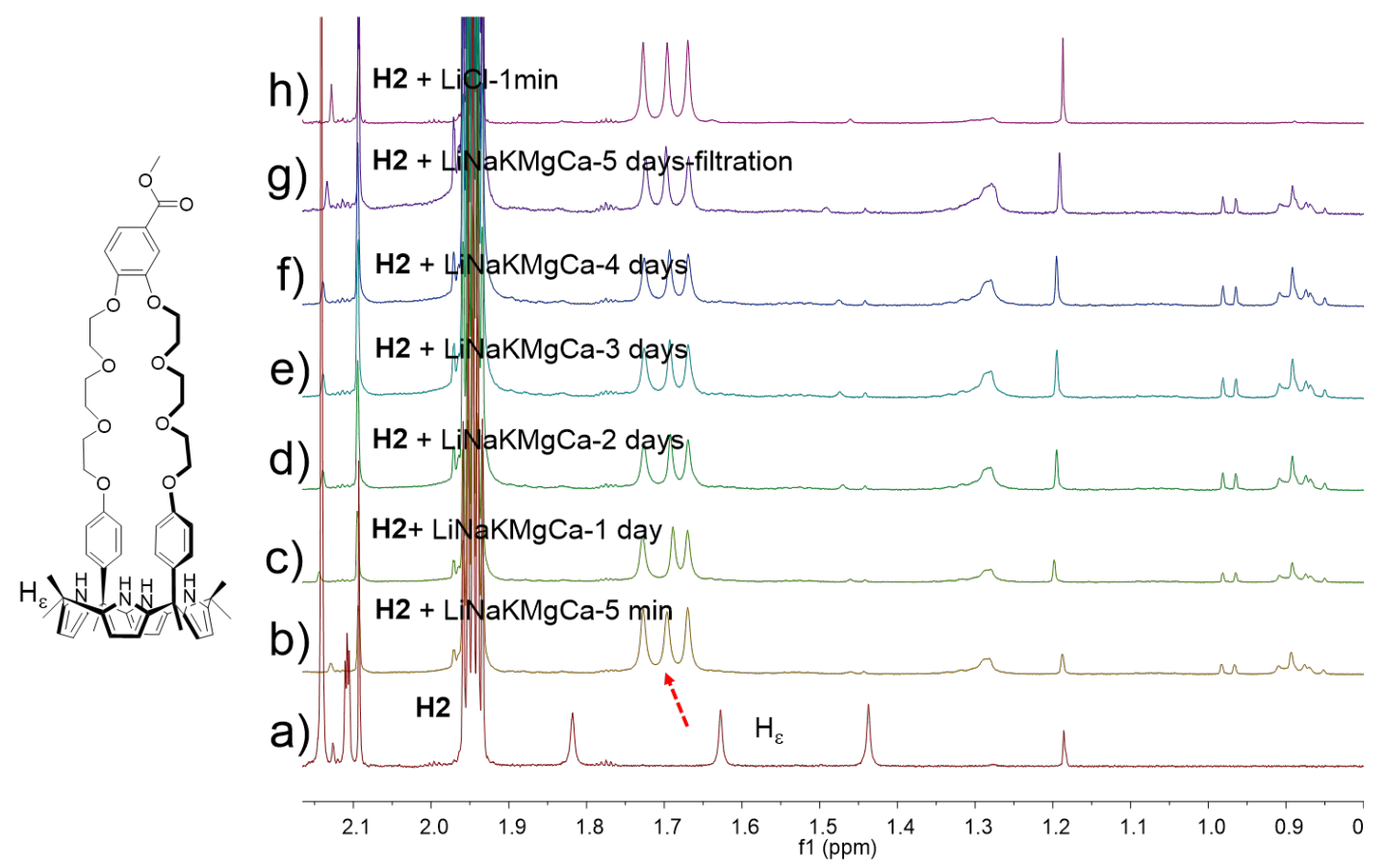

Figure S71. Partial ${ }^{1} \mathrm{H}$ NMR spectra (1.0-2.5) (400 MHz, CD 3 CN, $\left.298 \mathrm{~K}\right)$ of a) $5.00 \mathrm{mM}$ solution of H2; b) $5.00 \mathrm{mM}$ solution of $\mathbf{H 2}$ and 1 equiv of five salts ( $\mathrm{LiCl}, \mathrm{NaCl}, \mathrm{KCl}, \mathrm{MgCl}_{2}$ and $\mathrm{CaCl}_{2}$ ) after mixing for $1 \mathrm{~min}$; c) $5.00 \mathrm{mM}$ solution of $\mathbf{H 2}$ and 1 equiv of five salts ( $\mathrm{LiCl}, \mathrm{NaCl}, \mathrm{KCl}, \mathrm{MgCl}_{2}$ and $\mathrm{CaCl}_{2}$ ) after mixing for 1 day; d) $5.00 \mathrm{mM}$ solution of $\mathbf{H 2}$ and 1 equiv of five salts ( $\mathrm{LiCl}, \mathrm{NaCl}, \mathrm{KCl}, \mathrm{MgCl}_{2}$ and $\mathrm{CaCl}_{2}$ ) after mixing for 2 days; e) $5.00 \mathrm{mM}$ solution of $\mathbf{H 2}$ and 1 equiv of five salts ( $\mathrm{LiCl}, \mathrm{NaCl}, \mathrm{KCl}, \mathrm{MgCl}_{2}$ and $\mathrm{CaCl}_{2}$ ) after mixing for 3 days; f) $5.00 \mathrm{mM}$ solution of $\mathbf{H} 2$ and 1 equiv of five salts ( $\mathrm{LiCl}, \mathrm{NaCl}, \mathrm{KCl}, \mathrm{MgCl}_{2}$ and $\mathrm{CaCl}_{2}$ ) after mixing for 4 days; $\mathrm{g}$ ) filtered 5.00 $\mathrm{mM}$ solution of $\mathbf{H 2}$ and 1 equiv of five salts ( $\mathrm{LiCl}, \mathrm{NaCl}, \mathrm{KCl}, \mathrm{MgCl}_{2}$ and $\mathrm{CaCl}_{2}$ ) after mixing for after mixing for 5 days; h) $5.00 \mathrm{mM}$ solution of $\mathbf{H 2}$ and 1 equiv of $\mathrm{LiCl}$ after mixing for $1 \mathrm{~min}$. 

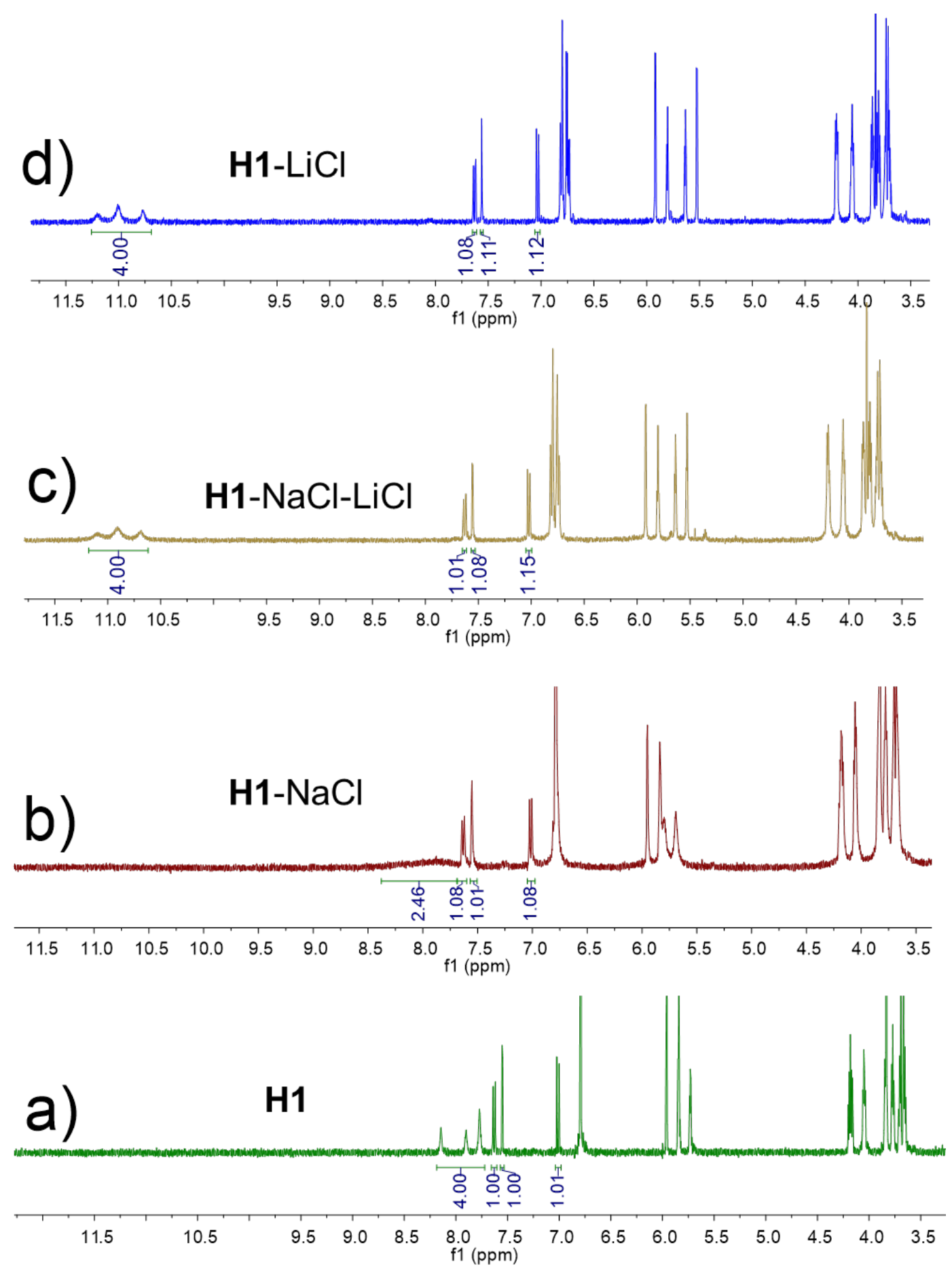

Figure S72. ${ }^{1} \mathrm{H}$ NMR spectra (400 MHz, $\mathrm{CD}_{3} \mathrm{CN}, 298 \mathrm{~K}$ ) of a) $5.00 \mathrm{mM}$ solution of solution of $\mathbf{H 1}$; b) $5.00 \mathrm{mM}$ solution of solution of $\mathbf{H 1}$ and 1 equiv of $\mathrm{NaCl}$ after mixing for 5 days; c) experiment shown in b) after adding 1 equiv of $\mathrm{LiCl}$; d) $5.00 \mathrm{mM}$ solution of $\mathbf{H 1}$ and 1 equiv of $\mathrm{LiCl}$ after mixing for $1 \mathrm{~min}$. 

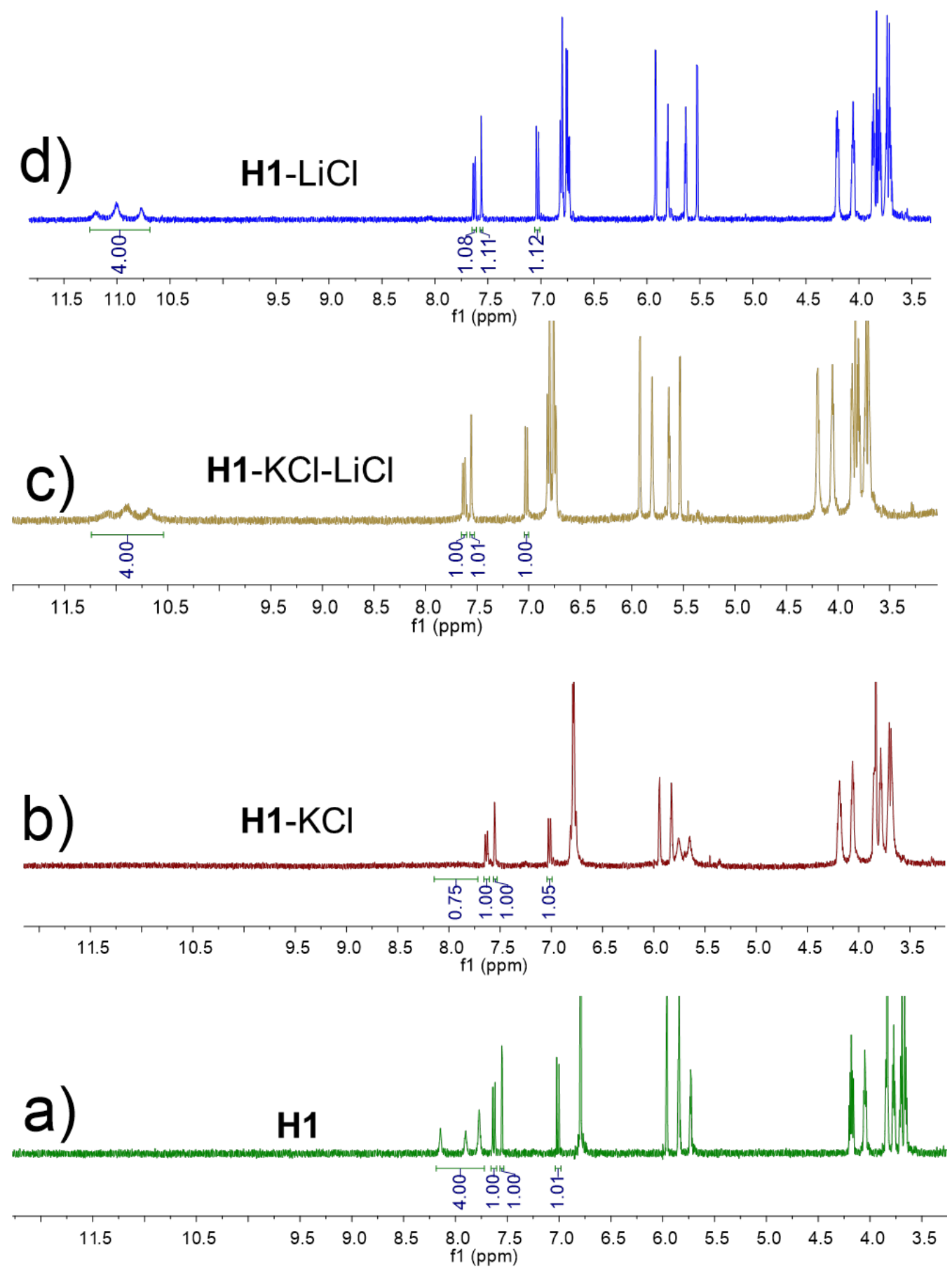

Figure S73. ${ }^{1} \mathrm{H}$ NMR spectra (400 MHz, $\mathrm{CD}_{3} \mathrm{CN}, 298 \mathrm{~K}$ ) of a) $5.00 \mathrm{mM}$ solution of $\mathbf{H 1}$; b) $5.00 \mathrm{mM}$ solution of $\mathbf{H 1}$ and 1 equiv of $\mathrm{KCl}$ after mixing for 5 days; c) experiment shown in b) after adding 1 equiv of $\mathrm{LiCl}$; d) $5.00 \mathrm{mM}$ solution of $\mathbf{H 1}$ and 1 equiv of $\mathrm{LiCl}$ after mixing for $1 \mathrm{~min}$. 

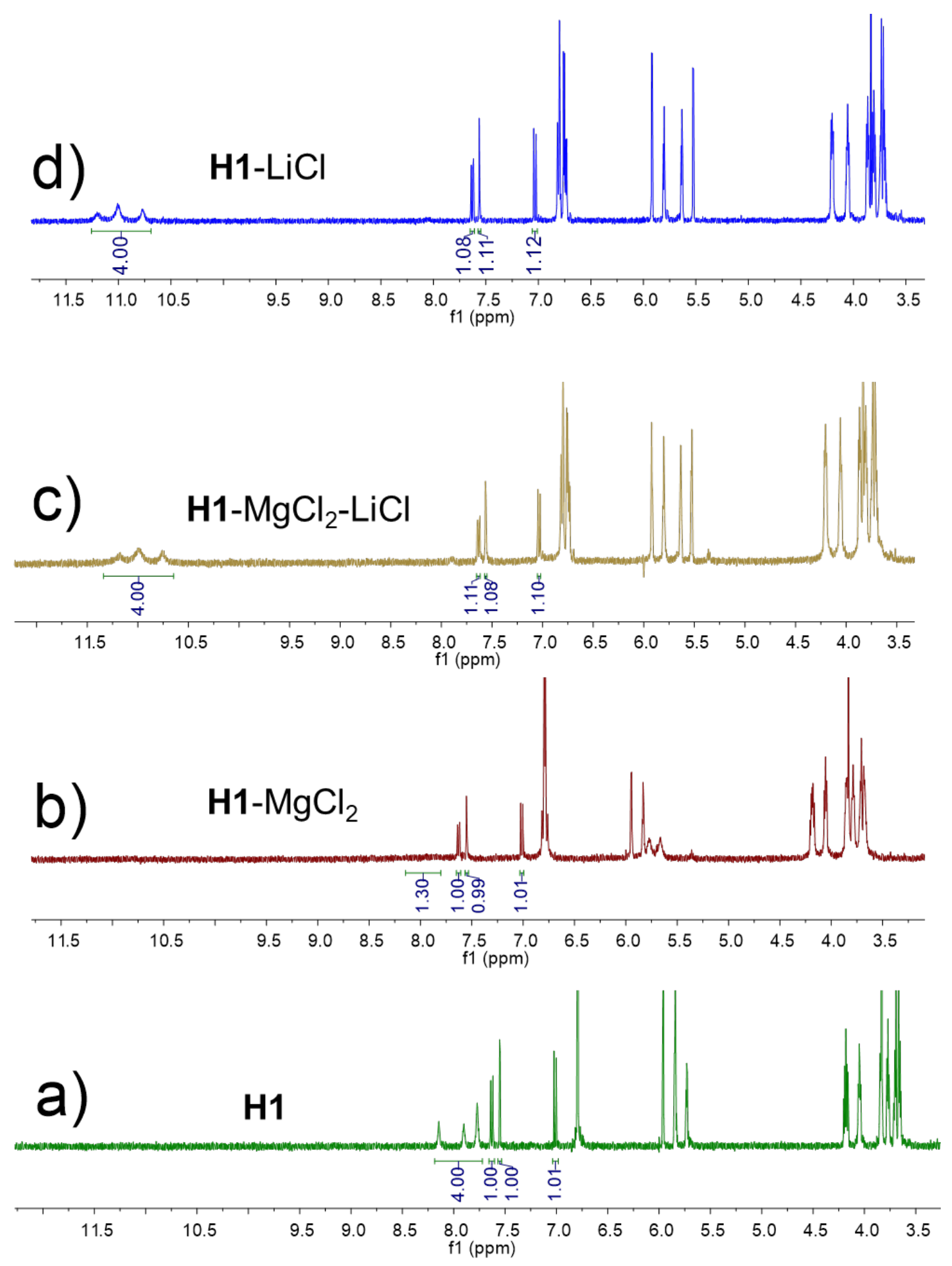

Figure S74. ${ }^{1} \mathrm{H}$ NMR spectra (400 MHz, $\mathrm{CD}_{3} \mathrm{CN}, 298 \mathrm{~K}$ ) of a) $5.00 \mathrm{mM}$ solution of $\mathbf{H 1}$; b) $5.00 \mathrm{mM}$ solution of $\mathbf{H 1}$ and 1 equiv of $\mathrm{MgCl}_{2}$ after mixing for 5 days; c) experiment shown in b) after adding 1 equiv of $\mathrm{LiCl}$; d) $5.00 \mathrm{mM}$ solution of $\mathbf{H 1}$ and 1 equiv of $\mathrm{LiCl}$ after mixing for $1 \mathrm{~min}$. 

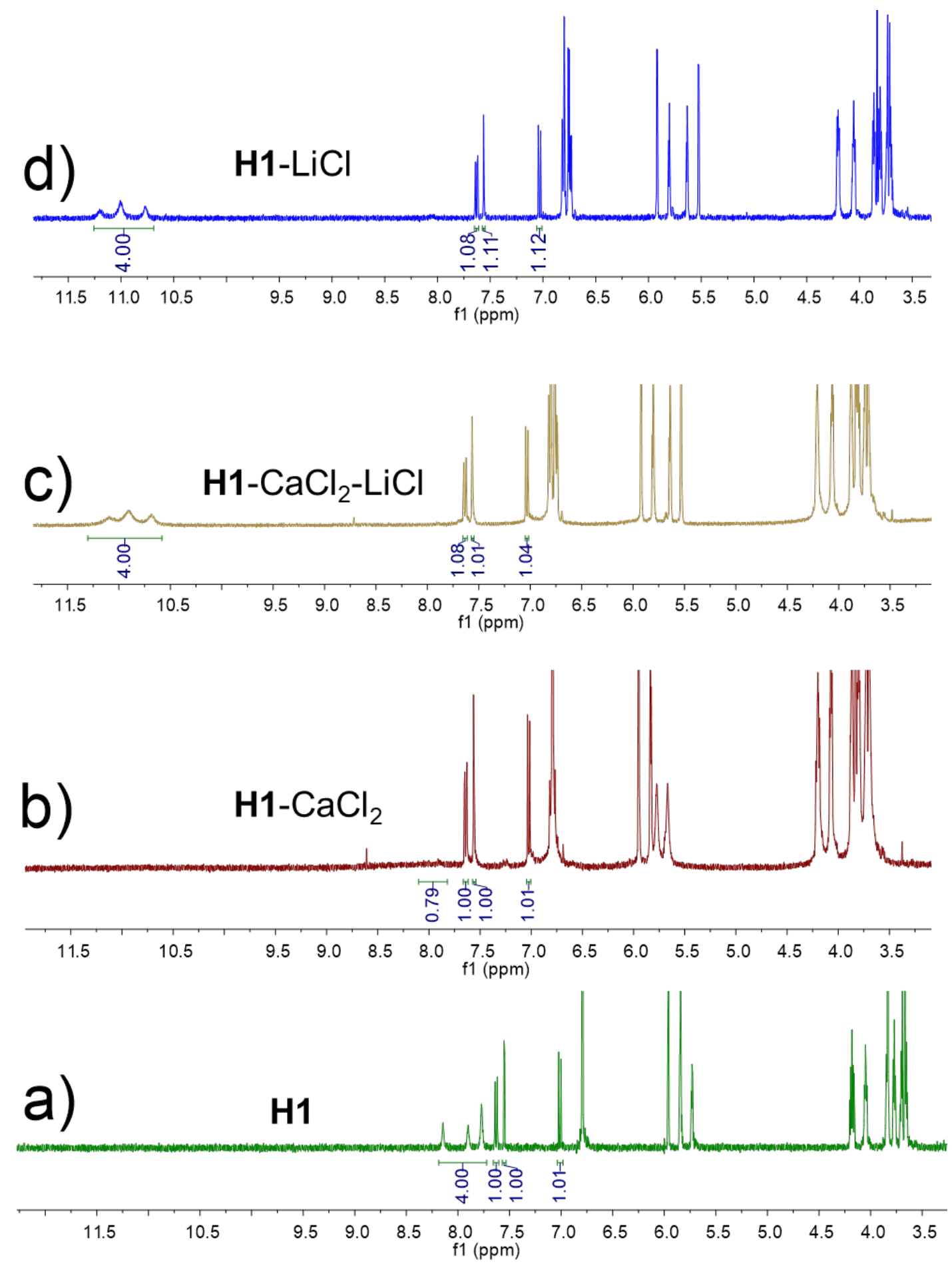

Figure S75. ${ }^{1} \mathrm{H}$ NMR spectra (400 MHz, $\mathrm{CD}_{3} \mathrm{CN}, 298 \mathrm{~K}$ ) of a) $5.00 \mathrm{mM}$ solution of $\mathbf{H 1}$; b) $5.00 \mathrm{mM}$ solution of $\mathbf{H 1}$ and 1 equiv of $\mathrm{CaCl}_{2}$ after mixing for 5 days; c) experiment shown in b) after adding 1 equiv of $\mathrm{LiCl}$; d) $5.00 \mathrm{mM}$ solution of $\mathbf{H 1}$ and 1 equiv of $\mathrm{LiCl}$ after mixing for $1 \mathrm{~min}$. 

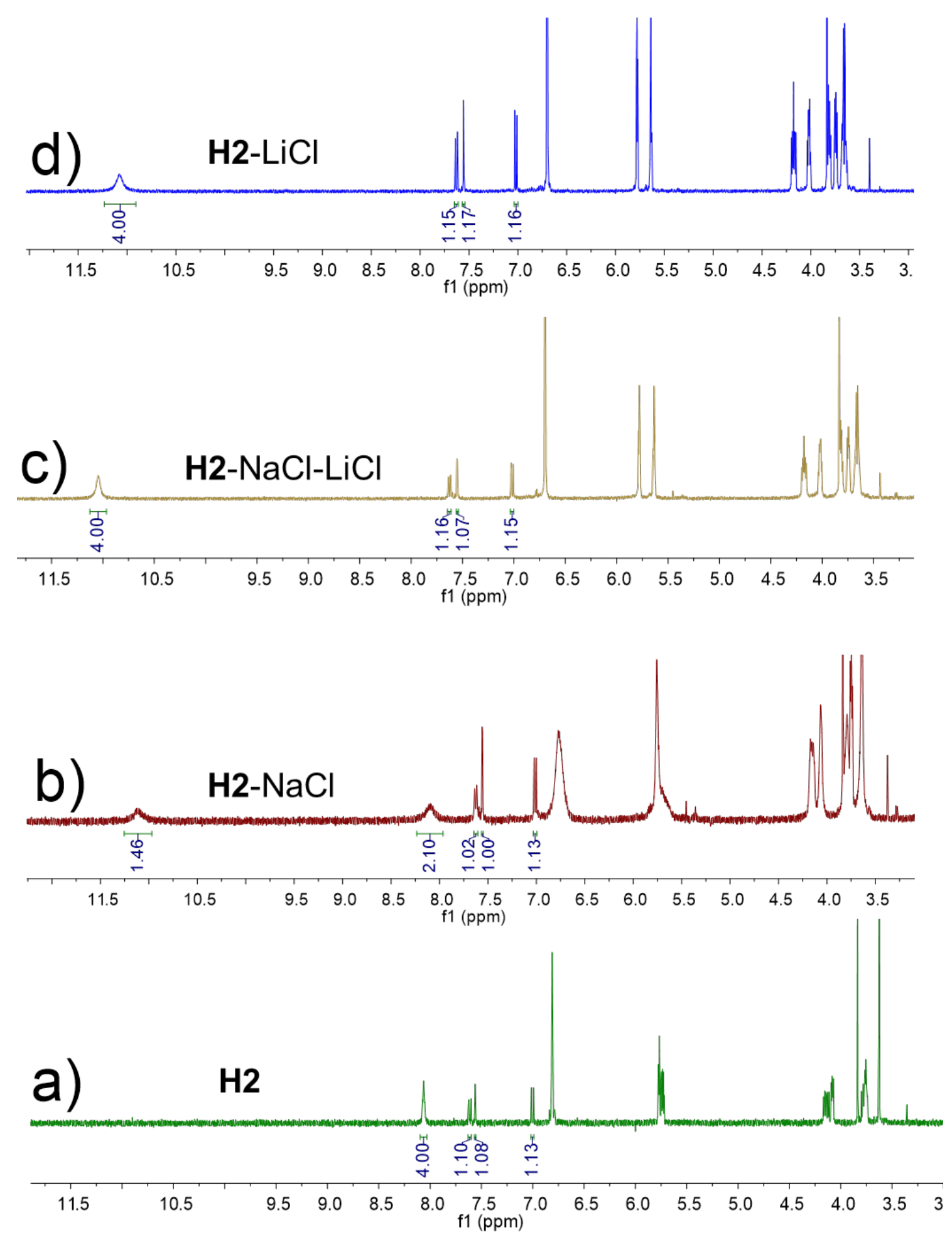

Figure S76. ${ }^{1} \mathrm{H}$ NMR spectra (400 MHz, $\mathrm{CD}_{3} \mathrm{CN}, 298 \mathrm{~K}$ ) of a) $5.00 \mathrm{mM} \mathrm{H2}$; b) $5.00 \mathrm{mM}$ solution of $\mathbf{H 2}$ and 1 equiv of $\mathrm{NaCl}$ after mixing for 5 days; c) experiment shown in b) after adding 1 equiv of $\mathrm{LiCl}$; d) $5.00 \mathrm{mM}$ solution of $\mathbf{H 2}$ and 1 equiv of $\mathrm{LiCl}$ after mixing for $1 \mathrm{~min}$. 

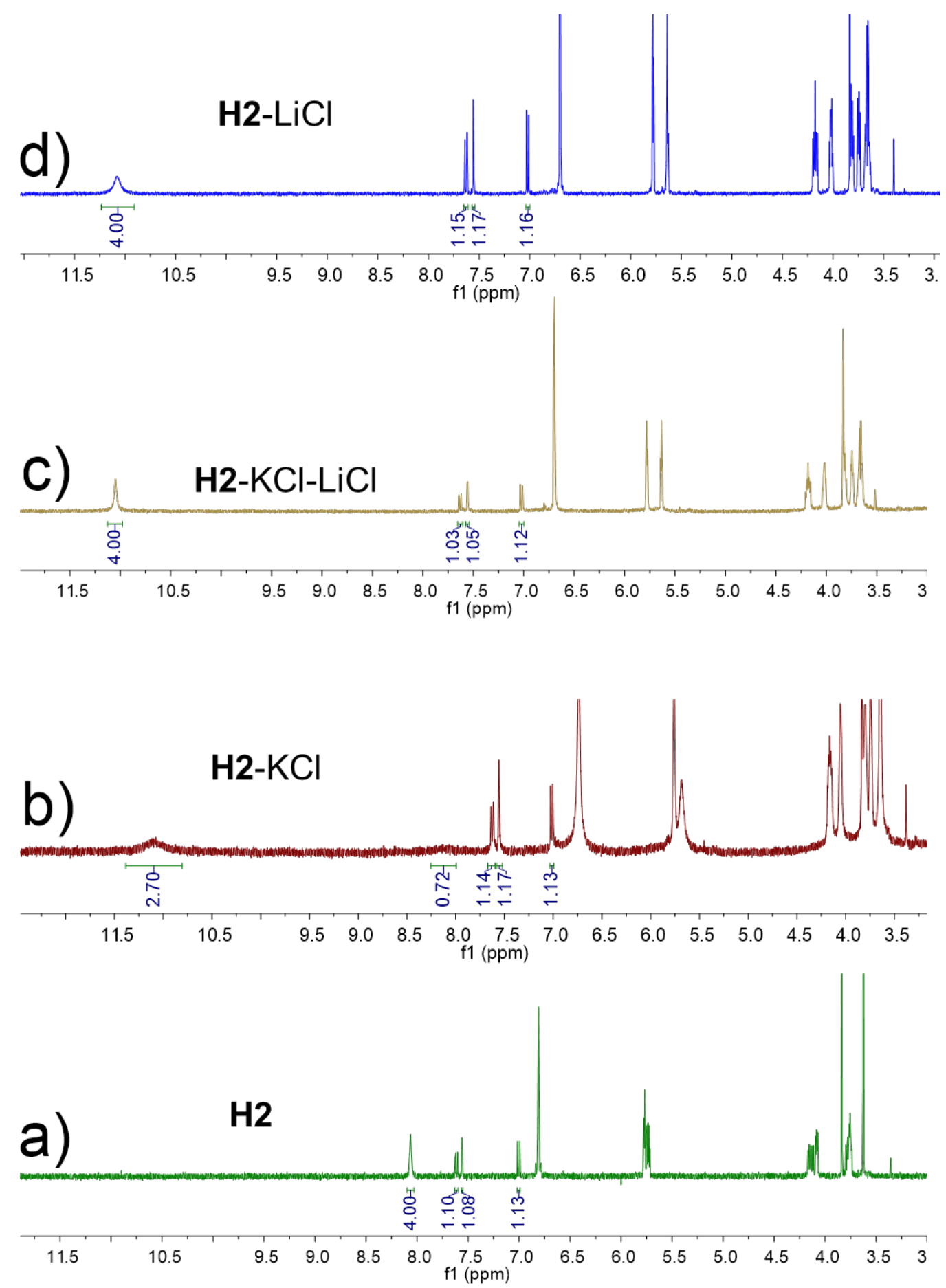

Figure S77. ${ }^{1} \mathrm{H}$ NMR spectra ( $400 \mathrm{MHz}, \mathrm{CD}_{3} \mathrm{CN}, 298 \mathrm{~K}$ ) of a) $5.00 \mathrm{mM}$ solution of $\mathbf{H 2}$; b) $5.00 \mathrm{mM}$ solution of $\mathbf{H 2}$ and 1 equiv of $\mathrm{KCl}$ after mixing for 5 days; c) experiment shown in b) after adding 1 equiv of $\mathrm{LiCl}$; d) $5.00 \mathrm{mM}$ solution of $\mathbf{H} \mathbf{2}$ and 1 equiv of $\mathrm{LiCl}$ after mixing for $1 \mathrm{~min}$. 

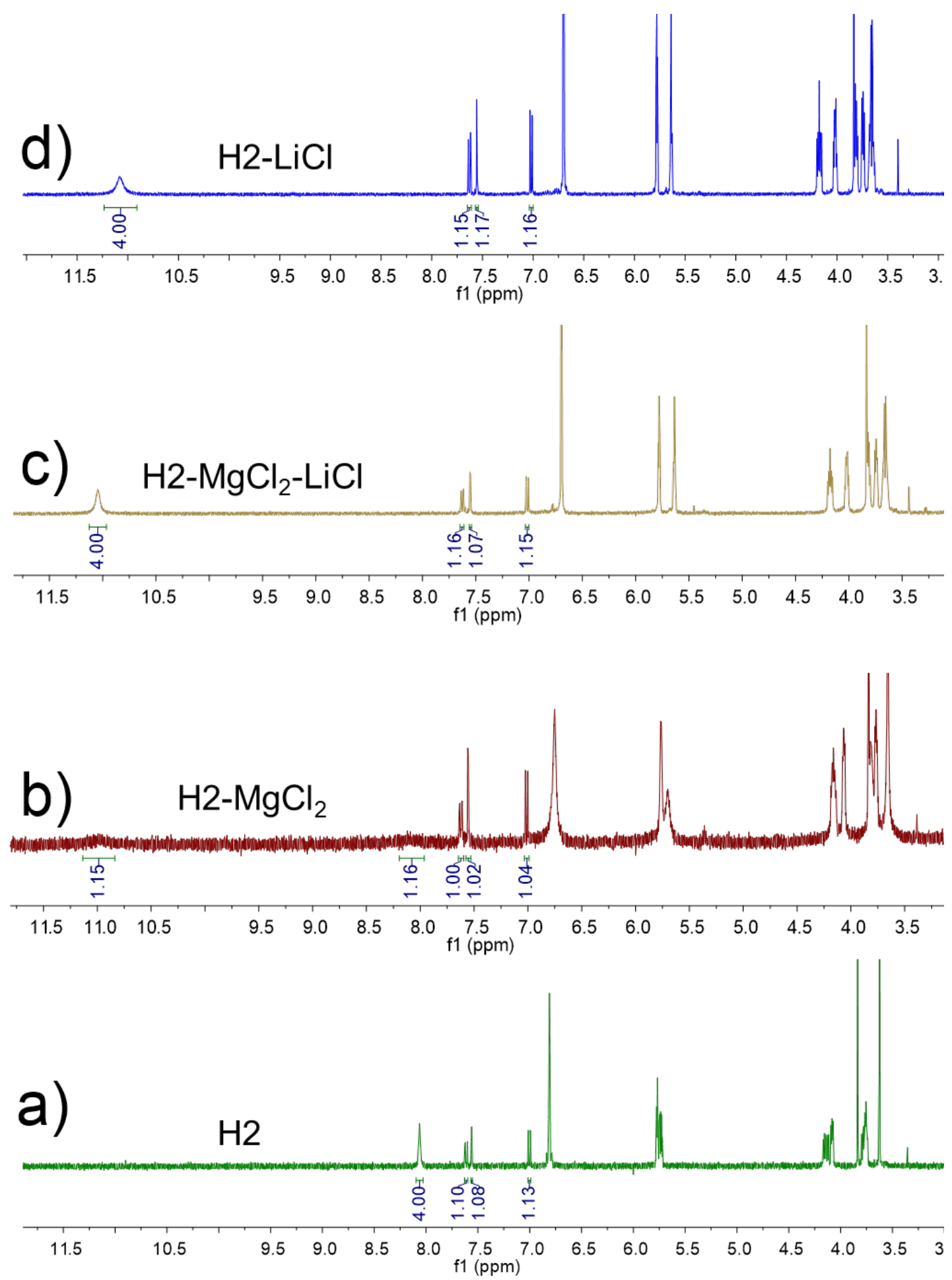

Figure S78. ${ }^{1} \mathrm{H}$ NMR spectra (400 MHz, $\mathrm{CD}_{3} \mathrm{CN}, 298 \mathrm{~K}$ ) of a) $5.00 \mathrm{mM}$ solution of $\mathbf{H 2}$; b) $5.00 \mathrm{mM}$ solution of $\mathbf{H 2}$ and 1 equiv of $\mathrm{MgCl}_{2}$ after mixing for 5 days; c) experiment shown in b) after adding 1 equiv of $\mathrm{LiCl}$; d) $5.00 \mathrm{mM}$ solution of $\mathbf{H} \mathbf{2}$ and 1 equiv of $\mathrm{LiCl}$ after mixing for $1 \mathrm{~min}$. 

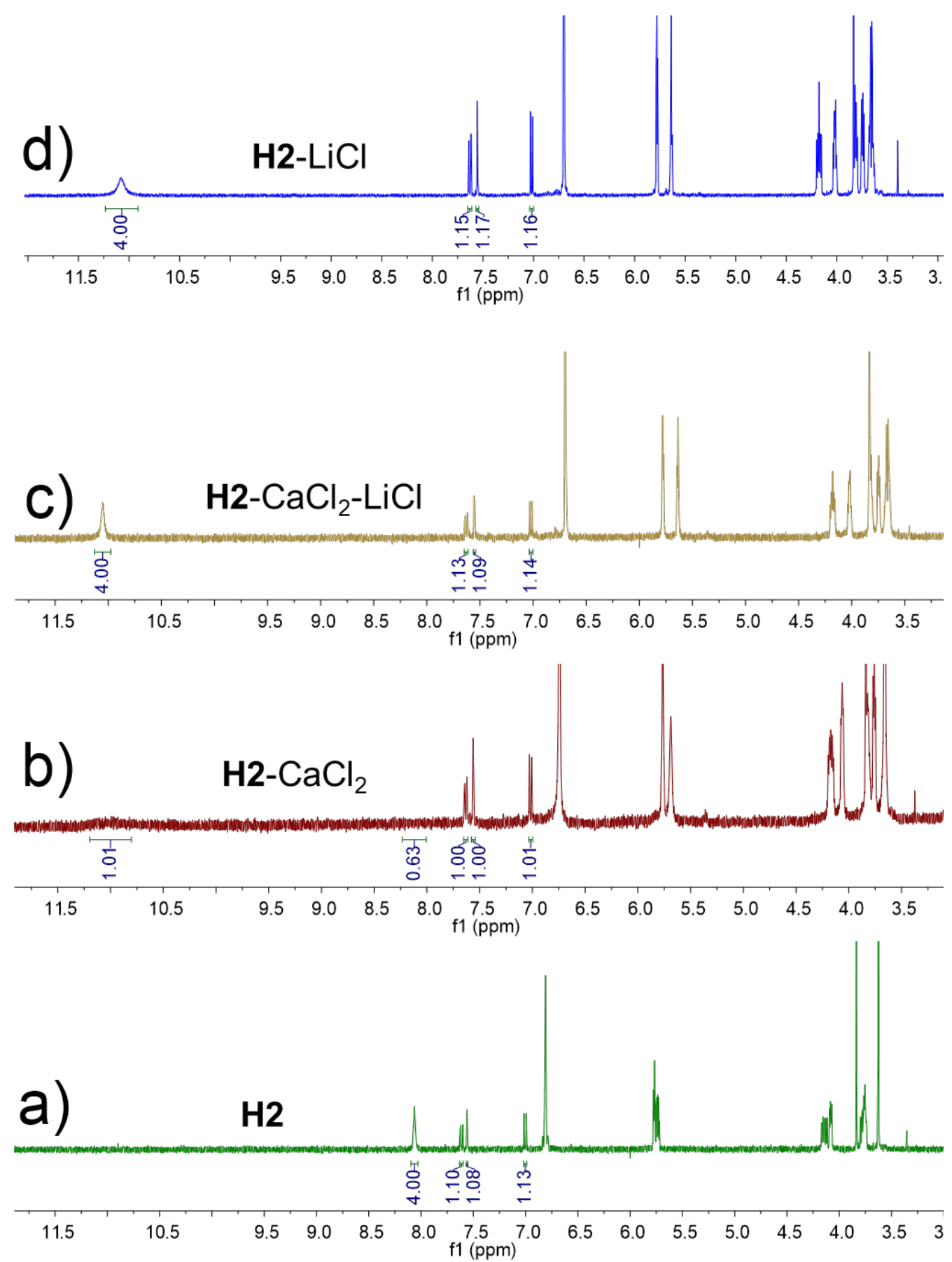

Figure S79. ${ }^{1} \mathrm{H}$ NMR spectra ( $400 \mathrm{MHz}, \mathrm{CD}_{3} \mathrm{CN}, 298 \mathrm{~K}$ ) of a) $5.00 \mathrm{mM}$ solution of $\mathbf{H 2}$; b) $5.00 \mathrm{mM}$ solution of $\mathbf{H 2}$ and 1 equiv of $\mathrm{CaCl}_{2}$ after mixing for 5 days; c) experiment shown in b) after adding 1 equiv of $\mathrm{LiCl}$; d) $5.00 \mathrm{mM}$ solution of $\mathbf{H 2}$ and 1 equiv of $\mathrm{LiCl}$ after mixing for $1 \mathrm{~min}$. 
10.9 Ratio of $\boldsymbol{H} \mathbf{1}$ and $\boldsymbol{H} \mathbf{2}$ involved in complexation as a function of equilibration time

Table S1. The ratio of $\mathbf{H 1}$ and $\mathbf{H 2}$ involved in the complexation after reaching the complexation balance

\begin{tabular}{|l|l|l|l|l|l|}
\hline & $\mathrm{LiCl}$ & $\mathrm{NaCl}$ & $\mathrm{KCl}$ & $\mathrm{MgCl}_{2}$ & $\mathrm{CaCl}_{2}$ \\
\hline $\mathbf{H 1}$ & $100 \%$ & $38.5 \%$ & $81.2 \%$ & $67.5 \%$ & $80.3 \%$ \\
\hline $\mathbf{H 2}$ & $100 \%$ & $47.5 \%$ & $82.0 \%$ & $74.5 \%$ & $84.3 \%$ \\
\hline
\end{tabular}

a)

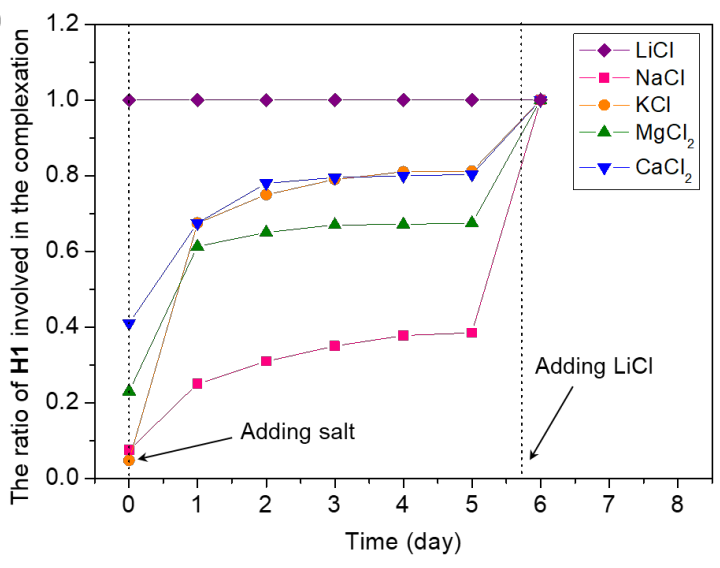

b)

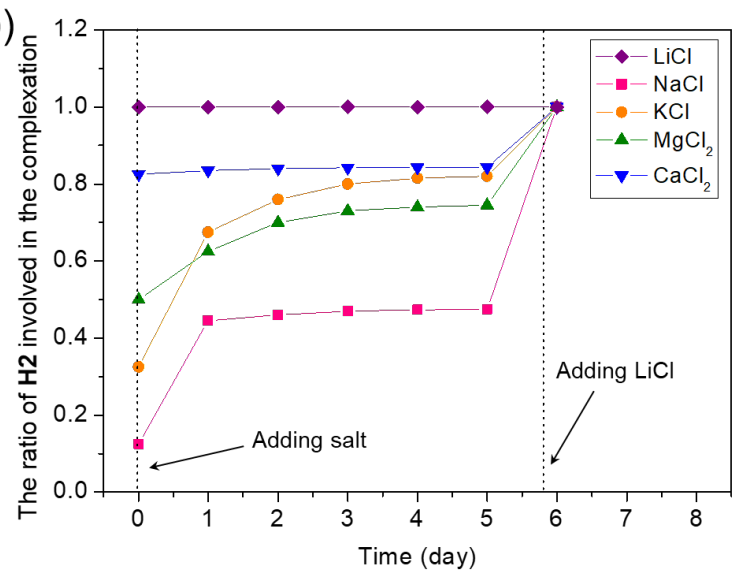

Figure S80. Ratio of $\mathbf{H 1}$ and $\mathbf{H 2}$ involved in complexation after reaching equilibrium. 


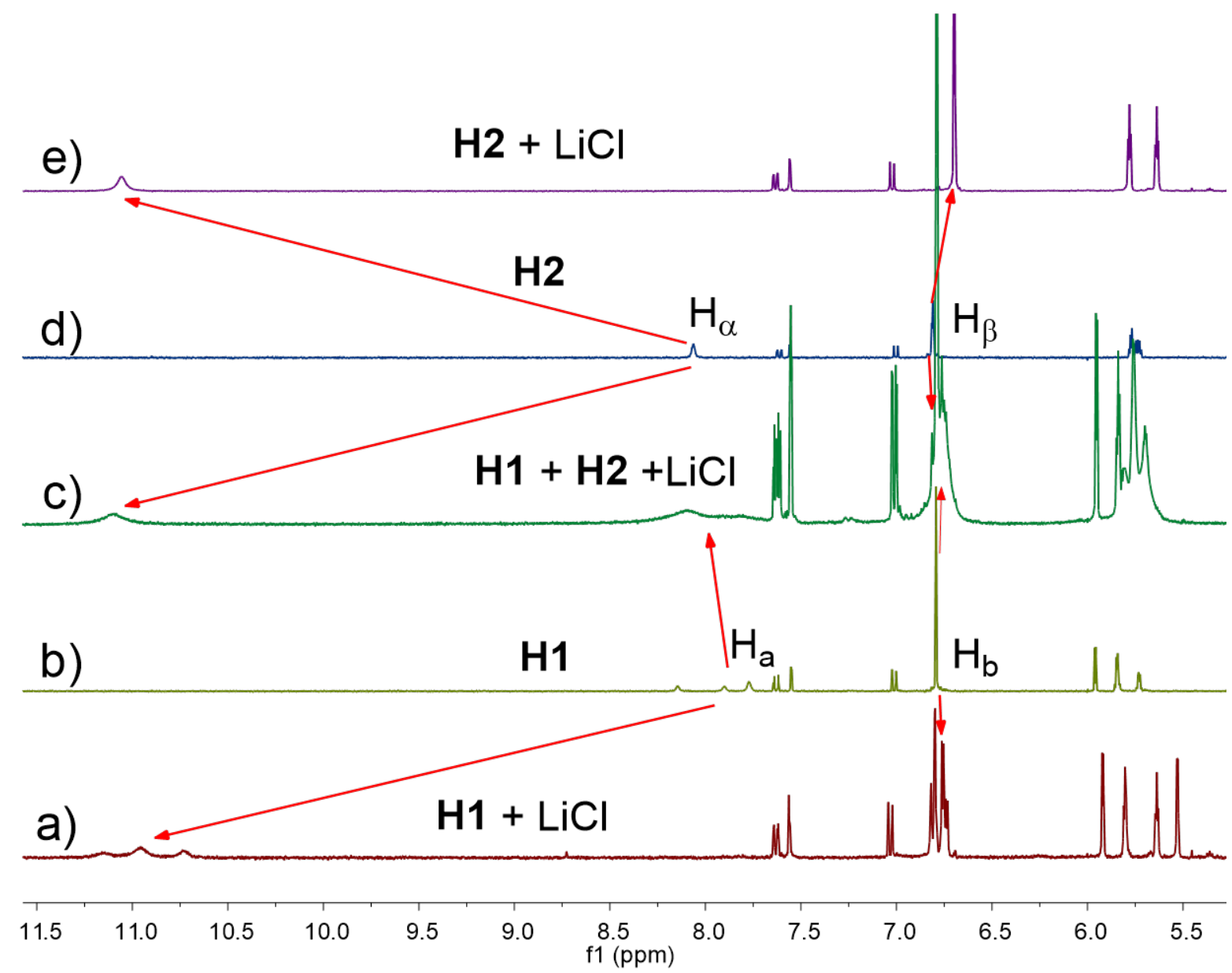

Figure S81. ${ }^{1} \mathrm{H}$ NMR spectra (400 MHz, $\left.\mathrm{CD}_{3} \mathrm{CN}, 298 \mathrm{~K}\right)$ of a) mixed solution of $\mathbf{H 1}$ and $\mathrm{LiCl}(5.00 \mathrm{mM}, 1: 1)$; b) H1 (5.00 mM); c) mixed solution consisting of H1, H2, and LiCl (5.00 mM, 1:1:1); d) H2 (5.00 mM); e) mixed solution of $\mathbf{H 2}$ and $\mathrm{LiCl}$ (5.00 mM, 1:1). 


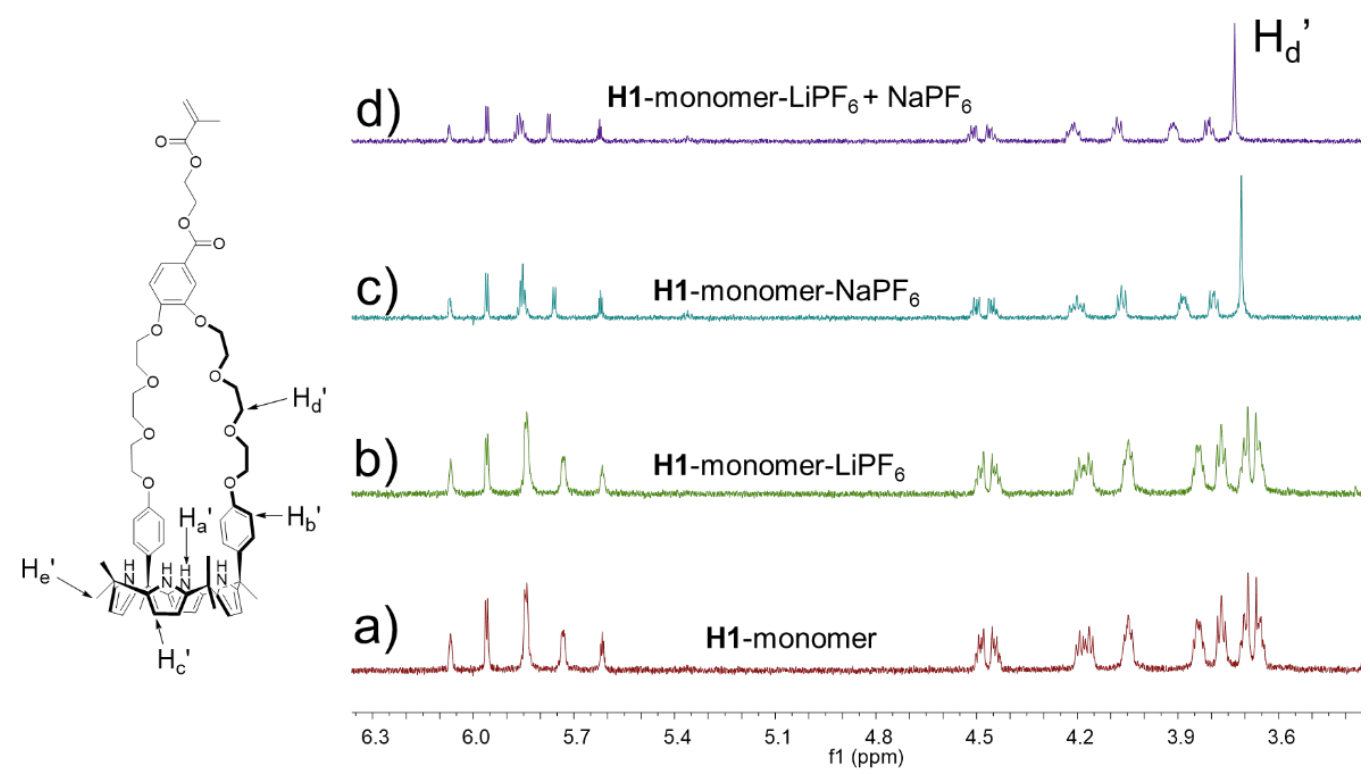

Figure S82. ${ }^{1} \mathrm{H}$ NMR spectra (400 MHz, $\left.\mathrm{CD}_{3} \mathrm{CN}, 298 \mathrm{~K}\right)$ of solution of a) $5.00 \mathrm{mM}$ solution of H1-monomer; b) $5.00 \mathrm{mM}$ solution of H1-monomer after adding $5.00 \mathrm{mM} \mathrm{LiPF}_{6}$; c) $5.00 \mathrm{mM}$ solution of H1-monomer after adding $5.00 \mathrm{mM} \mathrm{NaPF}_{6}$; d) $5.00 \mathrm{mM}$ solution of $\mathbf{H 1}$-monomer after adding $5.00 \mathrm{mM} \mathrm{LiPF}_{6}$ and $5.00 \mathrm{mM} \mathrm{NaPF}_{6}$.

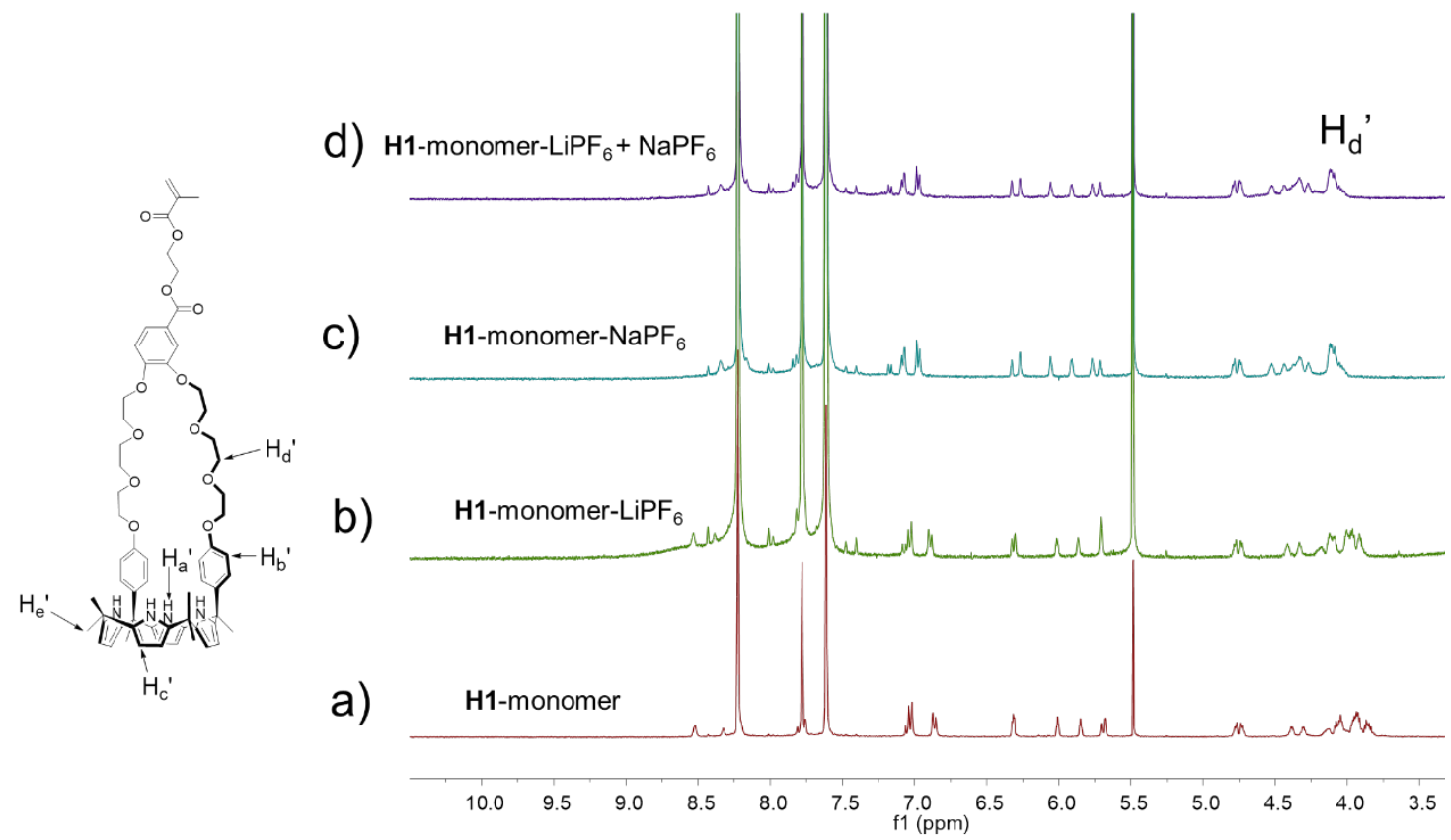

Figure S83. ${ }^{1} \mathrm{H}$ NMR spectra (400 MHz, nitrobenzene- $d_{6}, 298 \mathrm{~K}$ ) of solution of a) $5.00 \mathrm{mM}$ solution of H1-monomer; b) $5.00 \mathrm{mM}$ solution of H1-monomer after adding $5.00 \mathrm{mM} \mathrm{LiPF}_{6}$; c) $5.00 \mathrm{mM}$ solution of H1-monomer after adding $5.00 \mathrm{mM} \mathrm{NaPF}_{6}$; d) $5.00 \mathrm{mM}$ solution of H1-monomer after adding 5.00 $\mathrm{mM} \mathrm{LiPF}_{6}$ and $5.00 \mathrm{mM} \mathrm{NaPF}_{6}$. 
13. IR spectra of H1-monomer, H1-monomer, $\boldsymbol{G}$-control, $\boldsymbol{G 1}$, and $\boldsymbol{G} \mathbf{2}$

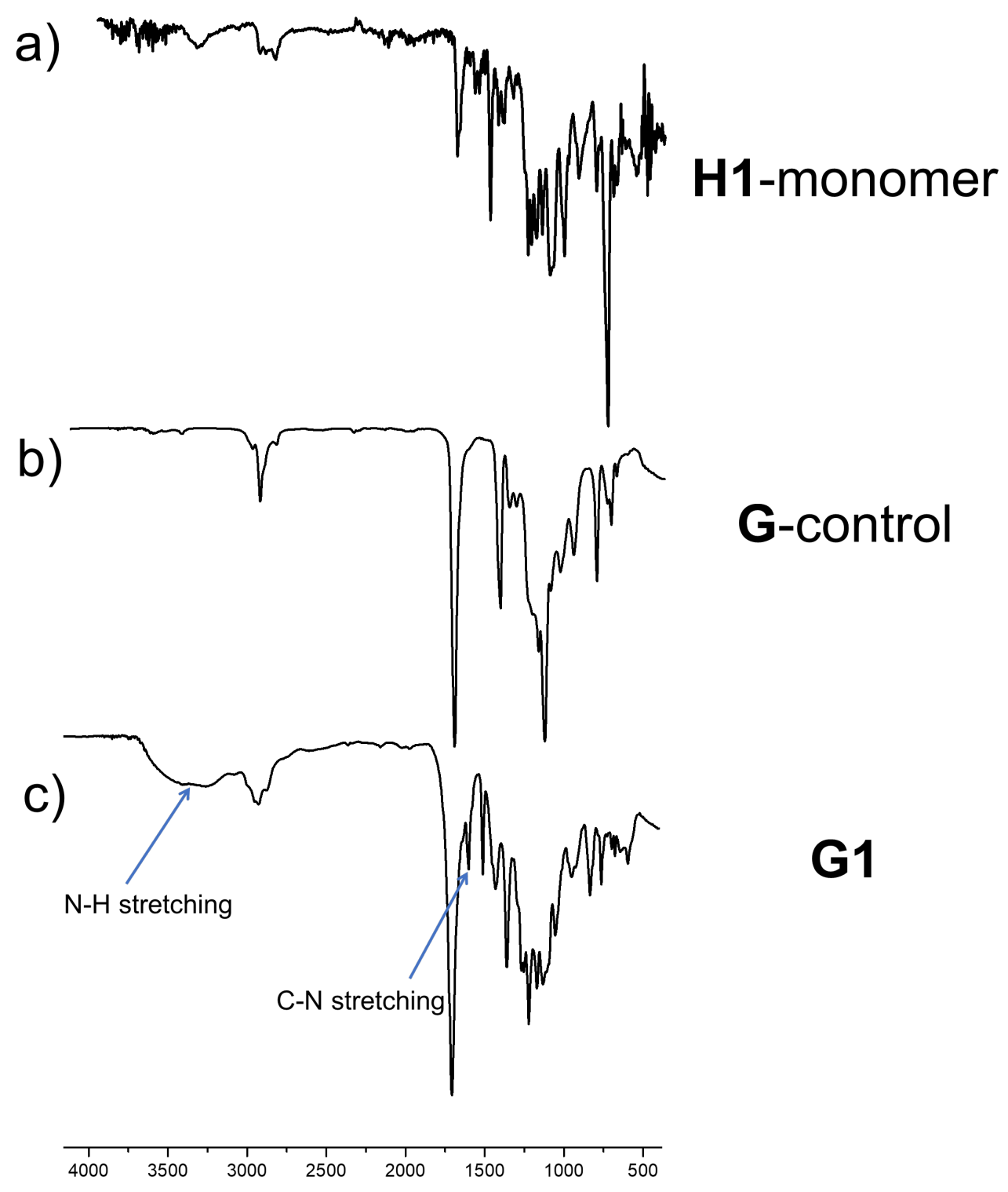

Figure. S84. IR spectra of a) H1-monomer, b) G-control and c) G1. 

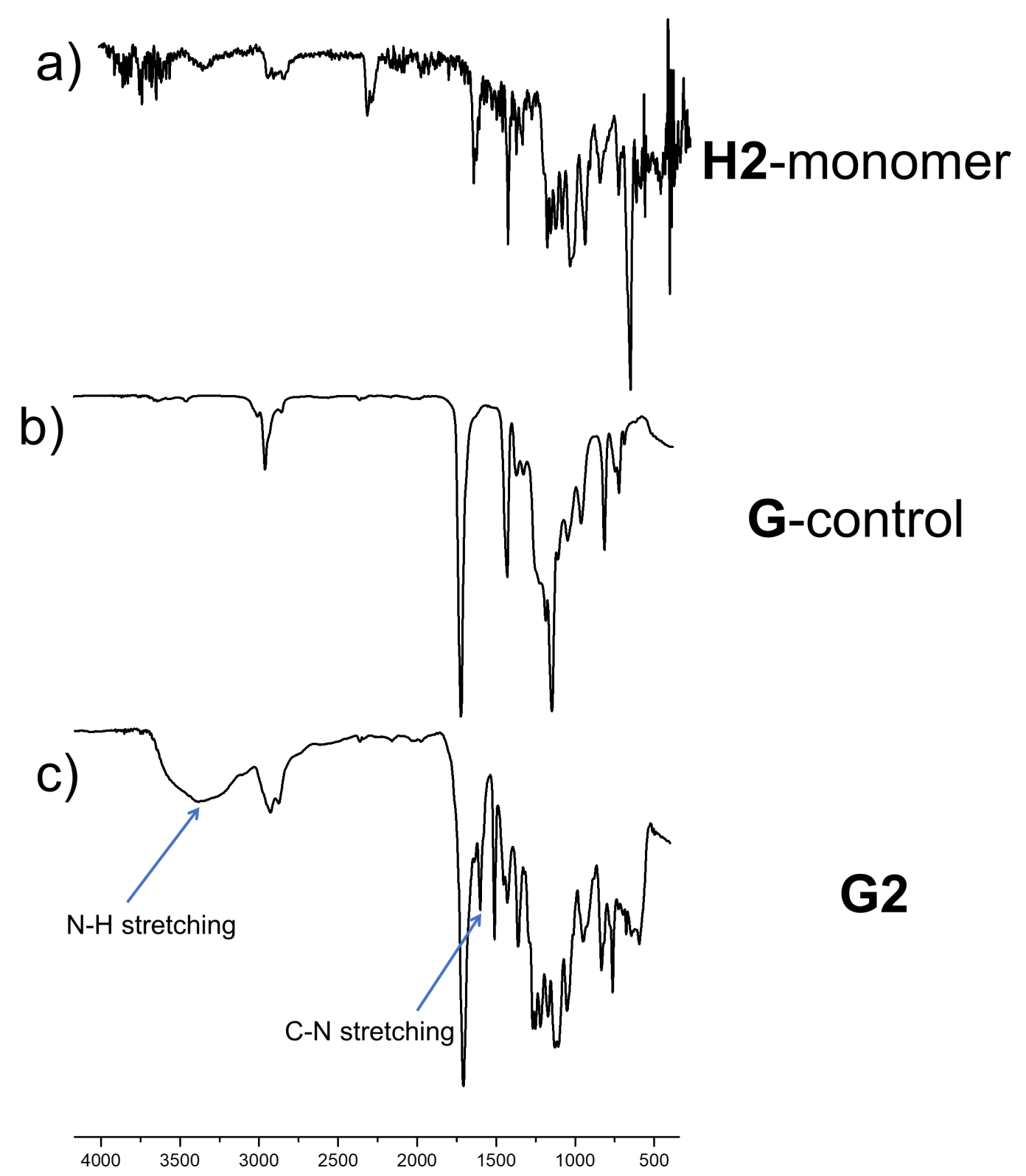

Figure. S85. IR spectra of a) H2-monomer, b) G-control and c) G2.

As shown in Figures S84 and S85, characteristic peaks associated with the monomers $\mathbf{H 1}$ and $\mathbf{H} 2$ were found in the infrared spectra of G1 and G2. As shown in Figures S78c and Figure S79c, the peak at around 3300-3500 $\mathrm{cm}^{-1} \mathrm{comes}$ from the N-H stretching in pyrrole. ${ }^{\mathrm{S} 3}$ The peak at around $1600 \mathrm{~cm}^{-1}$ was due to $\mathrm{C}=\mathrm{C}$ stretching of pyrrole. The peak at around $1100 \mathrm{~cm}^{-1}$ comes from the C-N stretching in pyrrole. ${ }^{\mathrm{S} 4}$ The peak at around $2900 \mathrm{~cm}^{-1}$ comes from the (O) $\mathrm{CH}_{3}$ stretching in polymethyl acrylate, while the peak at around $1700 \mathrm{~cm}^{-1}$ is assigned to the $\mathrm{C}=\mathrm{O}$ stretching of polymethyl acrylate. 
14. Thermogravimetric analysis of $\boldsymbol{P} \mathbf{1}, \boldsymbol{P} 2$, and $\boldsymbol{P}$-control

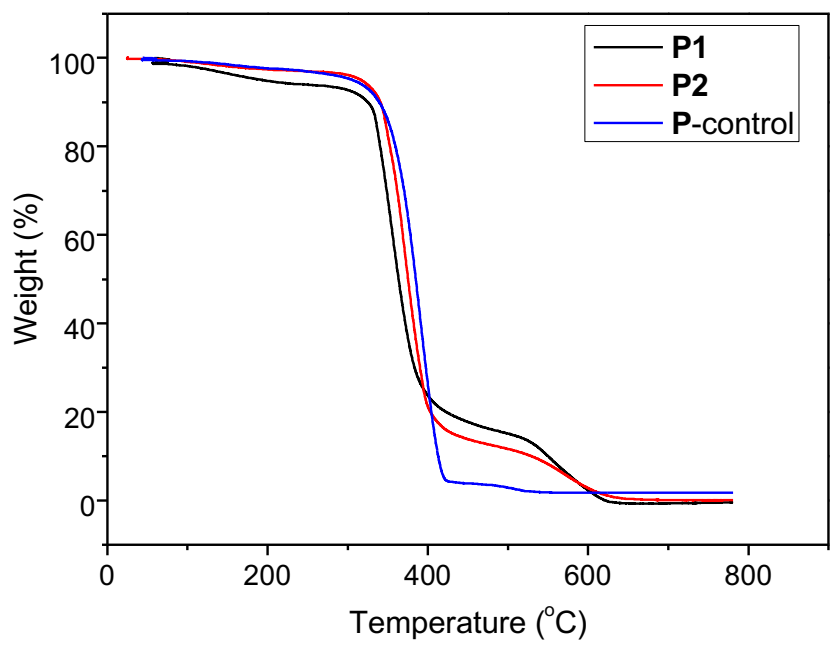

Figure S86. Thermogravimetric analysis of P1, P2, and P-control.

The thermogravimetric analysis measured the mass change of P1, P2 and P-control while they were heated. Compared to $\mathbf{P}$-control, $\mathbf{P 1}$ and $\mathbf{P 2}$ showed different mass change in the range of $390{ }^{\circ} \mathrm{C}$ to $630{ }^{\circ} \mathrm{C}$, which originated from the strapped calix[4]pyrrole $\mathbf{H 1}$ and $\mathbf{H 2}$ in the gel network. 
a)

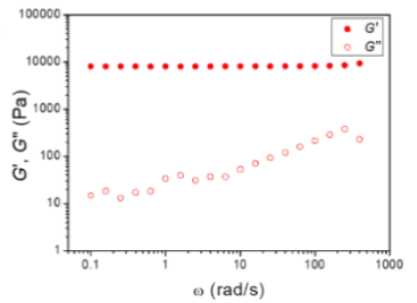

b)

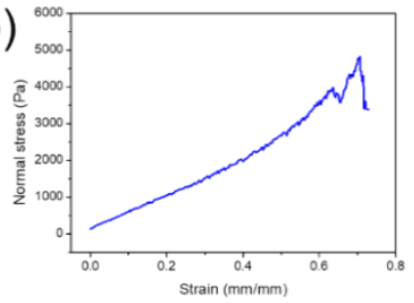

c)

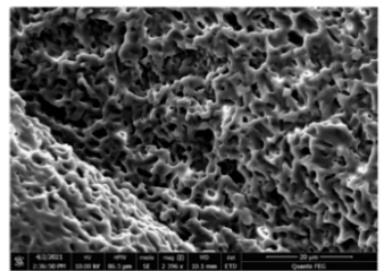

d)

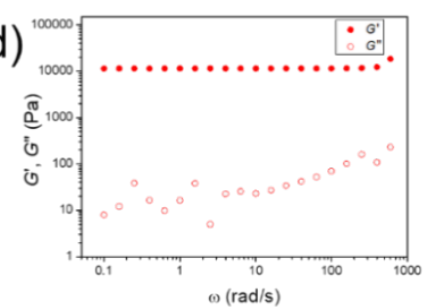

e)

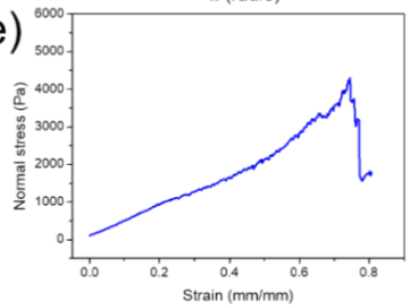

f)

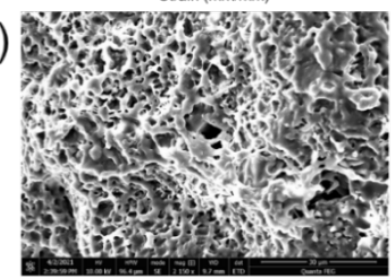

Figure S87. a) Storage modulus $\left(G^{\prime}\right)$ and loss modulus $\left(G^{\prime \prime}\right)$ of organic gel G1; b) Uniaxial compression behavior of organic gel G1; c) SEM image of organic gel G1; d) Storage modulus $\left(G^{\prime}\right)$ and loss modulus $\left(G^{\prime \prime}\right)$ of organic gel G2; e) Uniaxial compression behavior of organic gel G2; f) SEM image of organic gel G2.
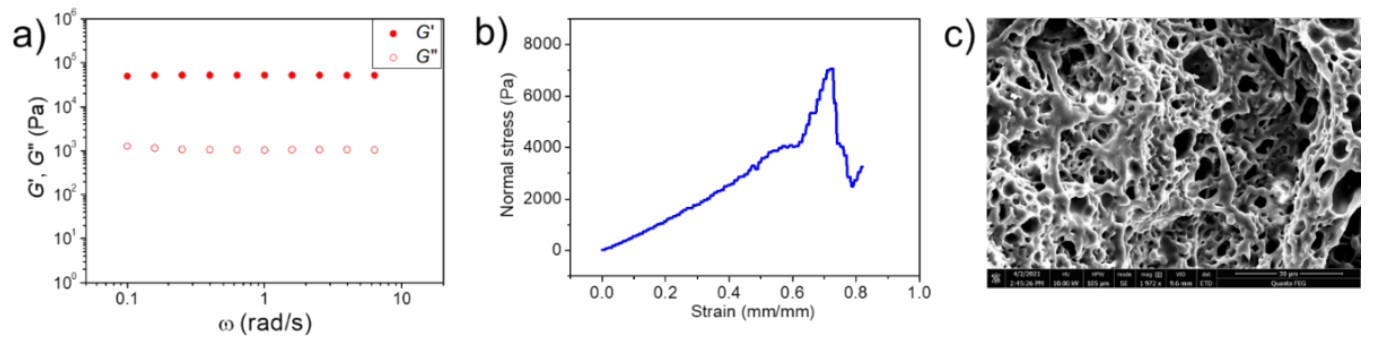

Figure S88. a) Storage modulus $\left(G^{\prime}\right)$ and loss modulus $\left(G^{\prime \prime}\right)$ of organic gel G-control; b) Uniaxial compression behavior of organic gel G-control; c) SEM image of organic gel G-control.

Rheological tests of organic gels $\mathbf{G 1}$ and $\mathbf{G 2}$ revealed that both the storage modulus, $G^{\prime}$, and loss modulus, $G^{\prime \prime}$, increase with frequency, and $G^{\prime}$ is always larger than $G^{\prime \prime}$ in the range of $0.1-1000 \mathrm{rad} / \mathrm{s}$, indicating that the sample is in the gel state with predominantly elastic property (Figures S87a and 87d). This highly viscoelastic gel keep its shape over time. As shown in Figures S86b and 86e, a compression test was used to evaluate the mechanical strength of $\mathbf{G 1}$ and G2. The fracture stress and strain were determined from the first peak of the compression curve. The fracture normal stress of G1 and G2 are respectively $3952 \mathrm{~Pa}$ and $3358 \mathrm{~Pa}$. The fracture strain of G1 and G2 are, respectively, 0.633 and 0.656 . The fracture compressive modulus was thus calculated to be $6243 \mathrm{~Pa}$ and $5118 \mathrm{~Pa}$ for G1 and G2, respectively. The control gel G-control has similar mechanical properties (Figure S88). The microstructures of G1, G2, and G-control were characterized using scanning electron microscopy (SEM) (Figures S87c, 87f and S88c). A three-dimensional porous network structure was observed. 
16. ${ }^{1} \mathrm{H} N \mathrm{NR}$ spectra of $\boldsymbol{H} \mathbf{1}$ and $\boldsymbol{H} \mathbf{2}+\mathrm{LiCl}$ recorded in methanol-d 4
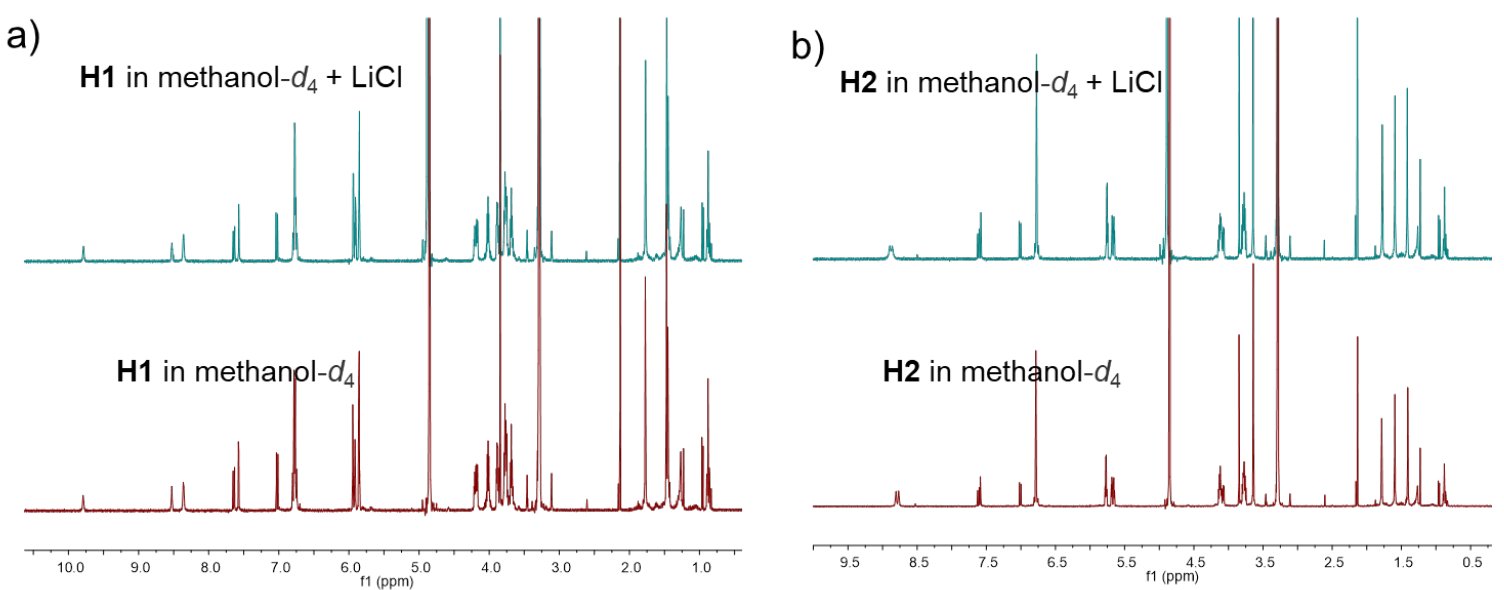

Figure S89. a) ${ }^{1} \mathrm{H}$ NMR spectra (400 MHz, methanol- $d_{4}$, $\left.298 \mathrm{~K}\right)$ of $\mathbf{H 1}$ before and after adding $\mathrm{LiCl}(5.00 \mathrm{mM}, 1: 1)$; b) ${ }^{1} \mathrm{H}$ NMR spectra (400 MHz, methanol- $d_{4}, 298 \mathrm{~K}$ ) of $\mathbf{H 2}$ before and after adding $\mathrm{LiCl}(5.00 \mathrm{mM}, 1: 1)$.

In the methanol solution of $\mathbf{H 1} / \mathbf{H 2}$, there was no change in the ${ }^{1} \mathrm{H}$ NMR spectra after adding LiCl. Therefore, $\mathbf{H 1} / \mathbf{H 2}$ cannot complex $\mathrm{LiCl}$ in methanol. 
17. Conductivity vs concentration studies for various metal salt solutions in acetonitrile and methanol
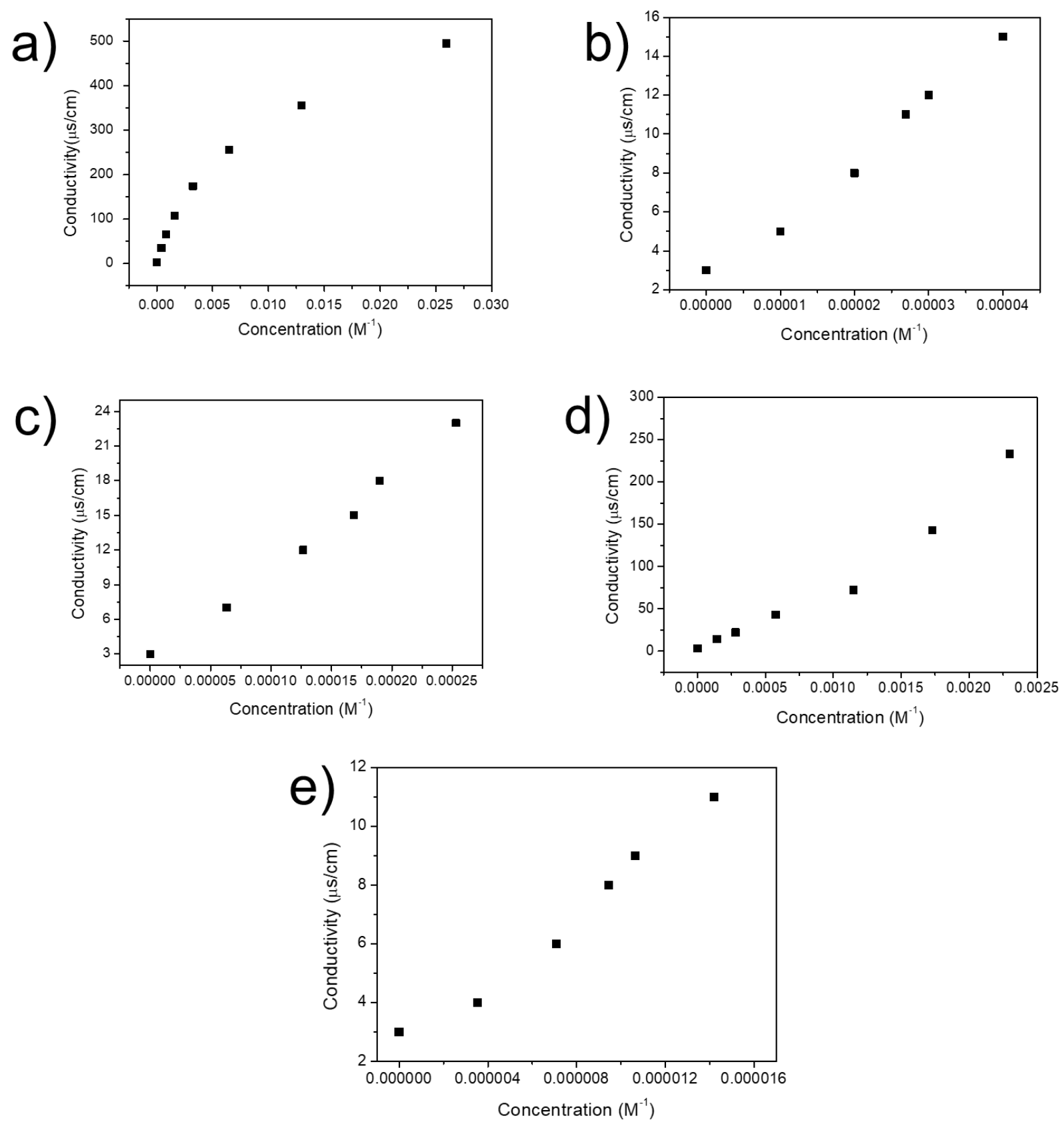

Figure S90. Conductivity of various metal salt solutions in acetonitrile versus concentration: a) $\mathrm{LiCl}, \mathrm{b}) \mathrm{NaCl}, \mathrm{c}$ ) $\mathrm{KCl}$, d) $\mathrm{MgCl}_{2}$, d) $\mathrm{CaCl}_{2}$. Note differences in the scale of the $\mathrm{X}$ and $\mathrm{Y}$ axes. The error in the individual values in this and like studies is $\leq 5 \%$. 

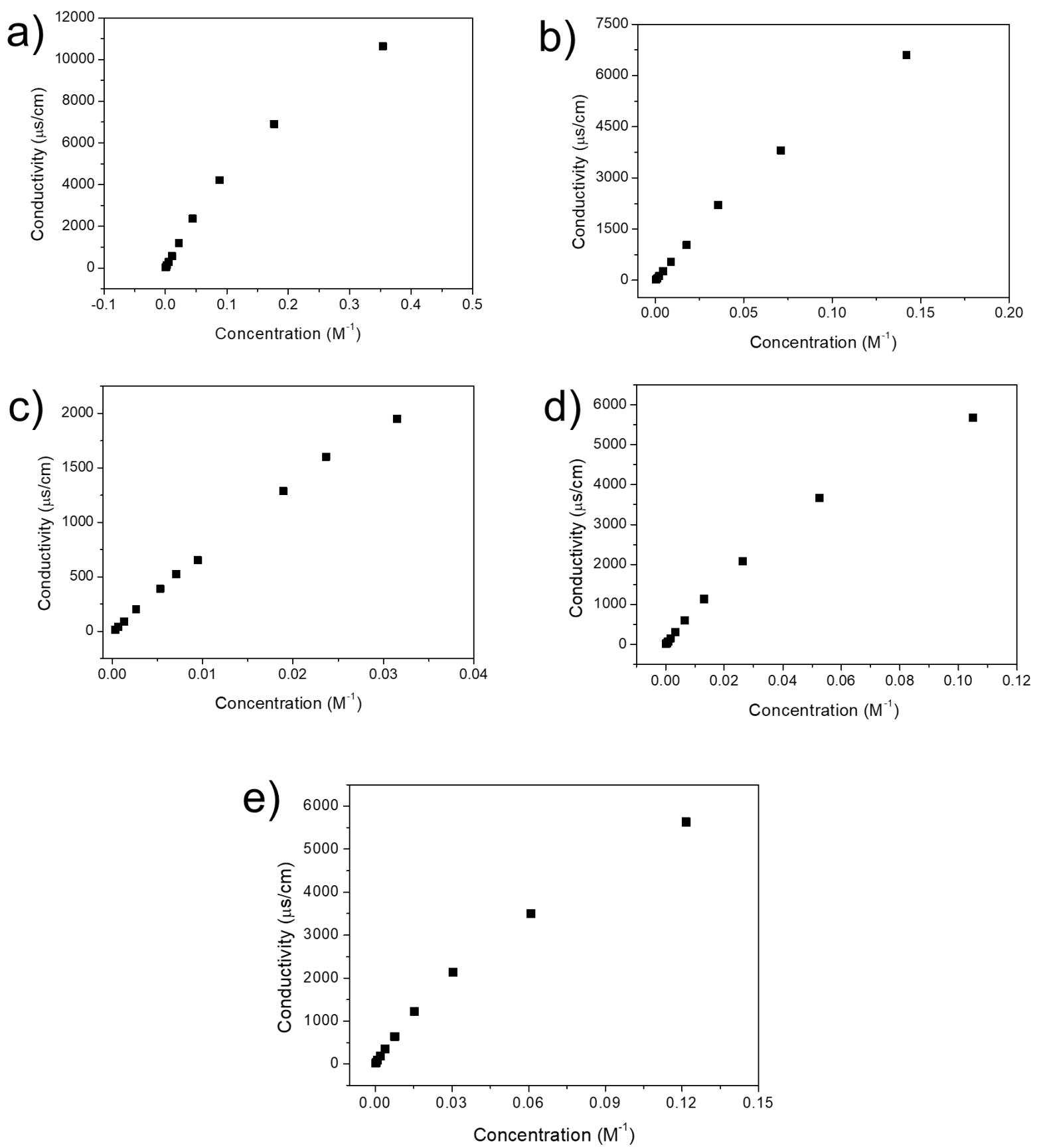

Figure S91. Conductivity of various metal salt solutions in methanol vs concentration: a) $\mathrm{LiCl}, \mathrm{b}$ ) $\mathrm{NaCl}, \mathrm{c}) \mathrm{KCl}$, d) $\left.\mathrm{MgCl}_{2}, \mathrm{~d}\right) \mathrm{CaCl}_{2}$. Note differences in the scale of the $\mathrm{X}$ and $\mathrm{Y}$ axes. 
18. Changes in conductivity of solutions wherein metal salts are extracted in acetonitrile and released in methanol

a)

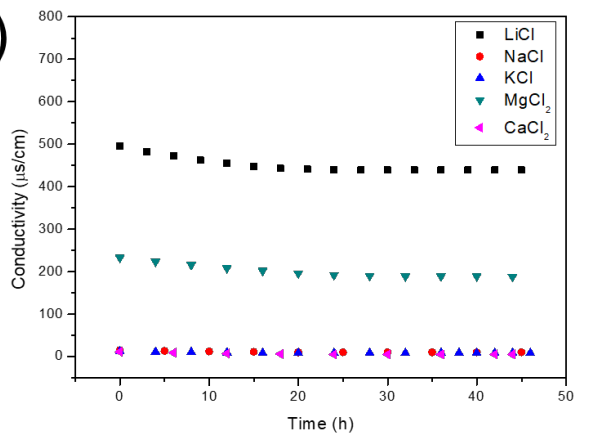

c)

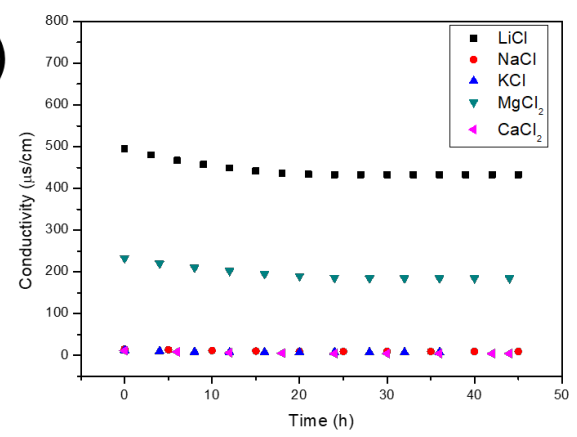

b)
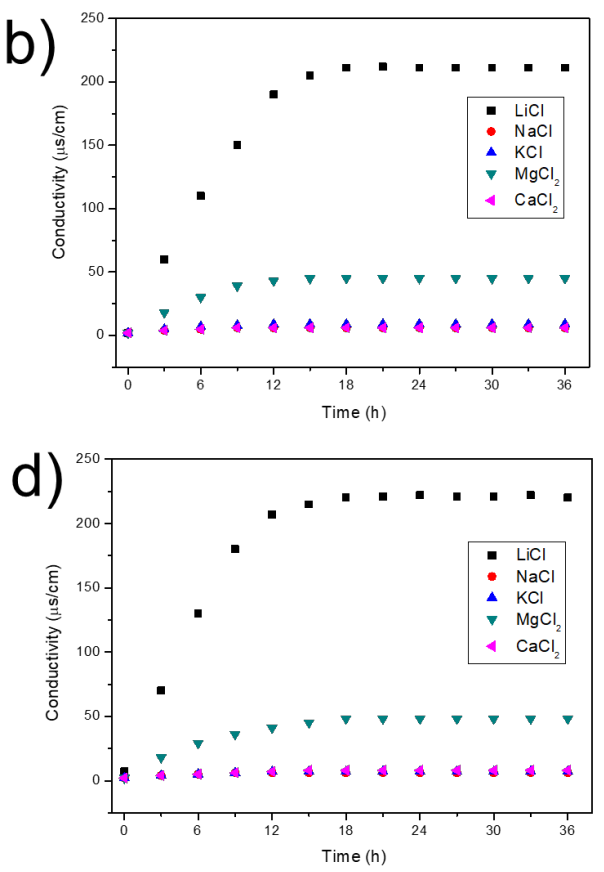

Figure S92. a) Conductivity changes for saturated acetonitrile solutions of various individual metal salts after adding P1; b) conductivity change for methanolic solutions after adding $\mathbf{G 1}$ that has been used to adsorb each metal salt; c) conductivity changes for saturated acetonitrile solutions of various individual metal salts after adding P2; b) conductivity change for methanolic solutions after adding $\mathbf{G} 2$ that has been used to adsorb each metal salt. 
19. ICP-MS results before extracting and after releasing treated by $\boldsymbol{P 1}$ or $\boldsymbol{P} 2$

Table S2. ICP-MS result before extracting in acetonitrile and after releasing in methanol

\begin{tabular}{|l|l|l|l|l|l|l|}
\hline Extractants & $\begin{array}{l}\text { Mixture } \\
\text { salts }\end{array}$ & Metals & $\begin{array}{l}\text { Metal } \\
\text { concentration } \\
\text { before } \\
\text { extracting } \\
\text { acetonitrile } \\
\text { (ppb) }\end{array}$ & $\begin{array}{l}\text { Normalized } \\
\text { concentration } \\
\text { before } \\
\text { extracting }\end{array}$ & $\begin{array}{l}\text { Metal } \\
\text { concentration } \\
\text { after } \\
\text { releasing } \\
\text { methanol } \\
\text { (ppb) }\end{array}$ & $\begin{array}{l}\text { Normalized } \\
\text { concentration } \\
\text { after }\end{array}$ \\
releasing
\end{tabular}

ICP-MS quantification studies before extracting in acetonitrile:

$1 \mathrm{ml}$ saturated solution of excess solid salts ( $\mathrm{LiCl}, \mathrm{NaCl}, \mathrm{KCl}, \mathrm{MgCl}_{2}$, and $\left.\mathrm{CaCl}_{2}\right)$ or $(\mathrm{LiCl}$ and $\mathrm{NaCl}$ ) were passed through 450-nm filters. The solvent was removed under reduced pressure. Then $5 \mathrm{ml}$ of $0.2 \mathrm{M}$ sulfuric acid was added into the vials to dissolve all the solids. Then, $5 \mu$ solution were removed and diluted to $5 \mathrm{ml}$ with $2 \% \mathrm{HNO}_{3}$ prior to analysis by ICP-MS. Control experiments were carried out in parallel using the solvent alone. All experiments were carried out in duplicate.

ICP-MS quantification studies after releasing in methanol:

$1 \mathrm{ml}$ methanol solution after gel release were passed through $450-\mathrm{nm}$ filters. The solvent was removed under reduced pressure. Then $1 \mathrm{ml}$ of $0.2 \mathrm{M}$ sulfuric acid was added into the vials to dissolve all the solids. Then, $5 \mu 1$ solution were removed and diluted to $5 \mathrm{ml}$ with $2 \% \mathrm{HNO}_{3}$ prior to analysis by ICP-MS. Control experiments were carried out in parallel using the solvent alone. All experiments were carried out in duplicate. 

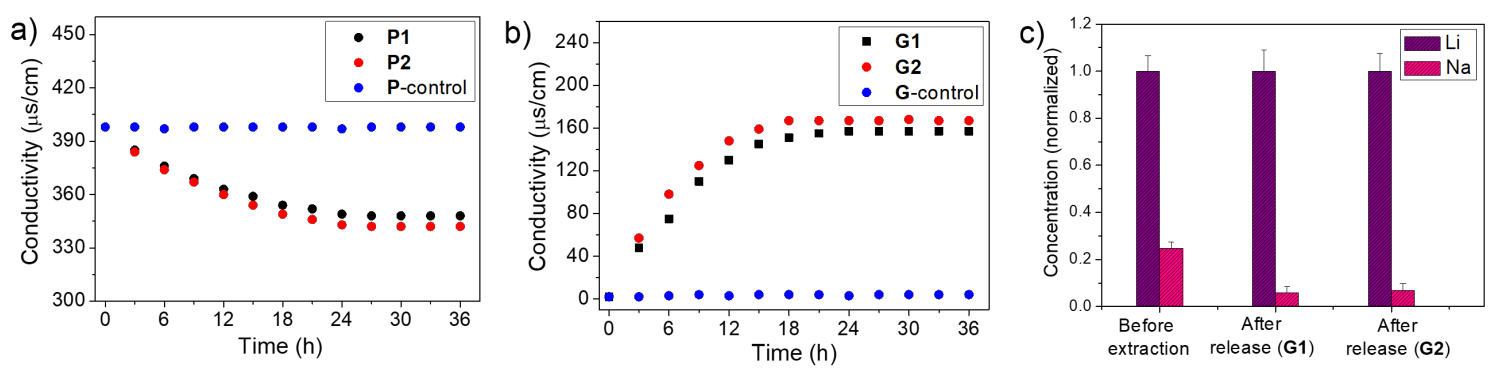

Figure S93. a) Conductivities of saturated acetonitrile solutions of $\mathrm{LiCl}$ and $\mathrm{NaCl}$ after contacting with $\mathbf{P 1}$, P2, and P-control (330 mg) for the indicated times; b) Conductivities of methanol solutions used to treat G1, G2, and Gcontrol after completion of the studies in a; c) Results of ICP-MS analyses: Normalized concentrations of Li and $\mathrm{Na}$ in acetonitrile and methanol, respectively, before and after extraction and release experiments involving mixed saturated solutions of $\mathrm{LiCl}$ and $\mathrm{NaCl}$ (see text for details). The error in the underlying data points is $\leq 5 \%$. 
a)

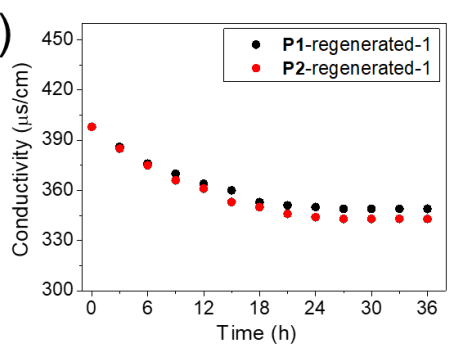

d)

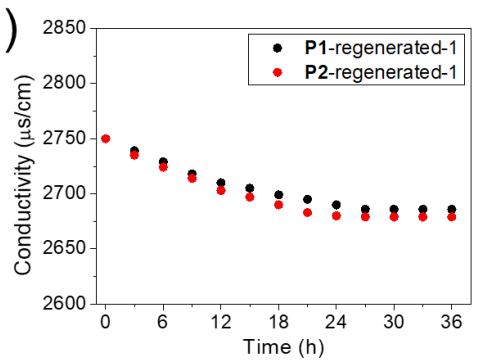

b)

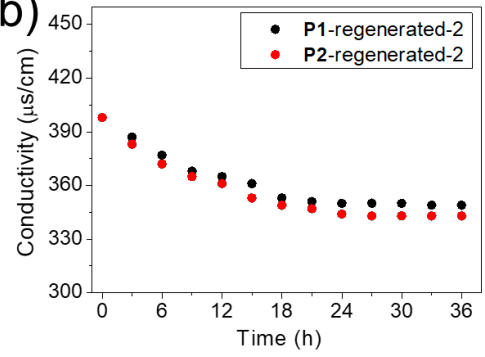

e)

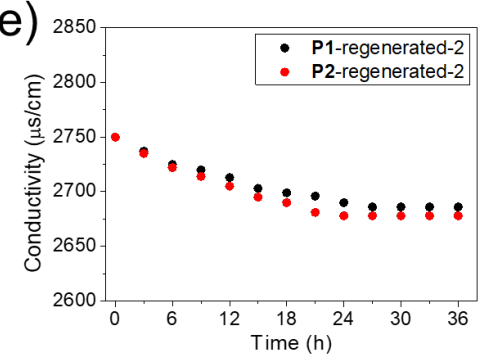

c)

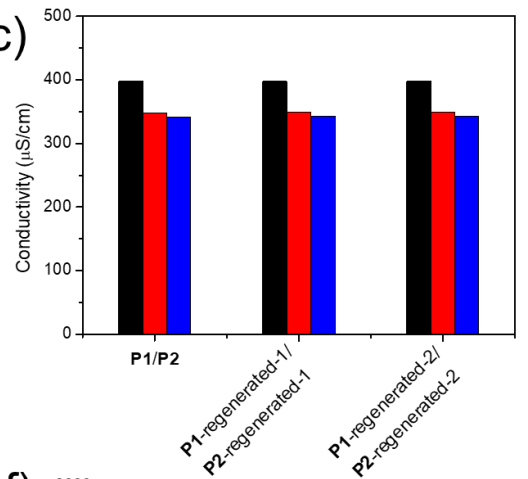

f)

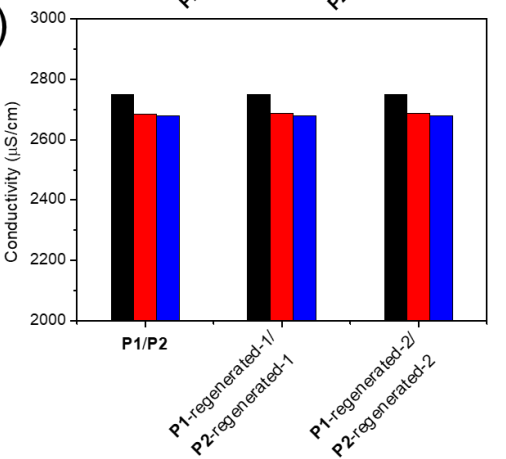

Figure S94. Conductivities of saturated acetonitrile solutions of $\mathrm{LiCl}$ and $\mathrm{NaCl}$ after contacting with $330 \mathrm{mg}$ a) P1regenerated-1 and P2-regenerated-1; b) P1-regenerated-2 and P2-regenerated-2 for the indicated times; c) Conductivities of saturated acetonitrile solutions of $\mathrm{LiCl}$ and $\mathrm{NaCl}$ before (black bar) and after being treated with $\mathbf{P 1}$, P1-regenerated-1, and P1-regenerated-2 (red bar); P2, P2-regenerated-1, and P2-regenerated-2 (blue bar) respectively; conductivities of saturated acetonitrile solutions of five metal salts ( $\mathrm{LiCl}, \mathrm{NaCl}, \mathrm{KCl}, \mathrm{MgCl}_{2}$, and $\mathrm{CaCl}_{2}$ ) after contacting with $330 \mathrm{mg}$ d) P1-regenerated-1 and P2-regenerated-1; e) P1-regenerated-2 and P2-regenerated-2 for the indicated times; f) conductivities of saturated acetonitrile solutions of five metal salts ( $\mathrm{LiCl}, \mathrm{NaCl}, \mathrm{KCl}, \mathrm{MgCl}_{2}$, and $\mathrm{CaCl}_{2}$ ) before (black bar) and after being treated with P1, P1-regenerated-1, and P1-regenerated-2 (red bar); P2, P2-regenerated-1, and P2-regenerated-2 (blue bar), respectively. 
21. Photographs of $\boldsymbol{P 1 / P 2}$ before and after extraction of $\mathrm{LiCl}$

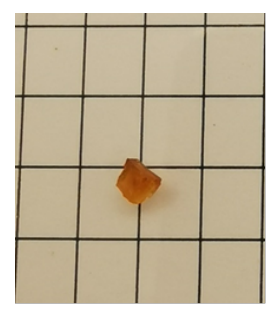

P1

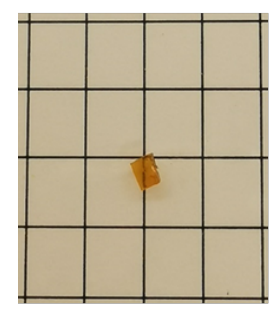

P2
Extracting LiCl in acetonitrile

Extracting $\mathrm{LiCl}$ in acetonitrile

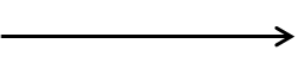

G2

Figure S95. Photographs of $\mathbf{P 1 / P 2}$ before and after extraction of $\mathrm{LiCl}$ 


\section{X-ray experimental}

X-ray experimental for the complex $\mathbf{H 1} \cdot \mathrm{LiCl}(\mathrm{CCDC}$ deposition number: 2107227)

Crystals grew as clusters of colorless prisms by vapor diffusion of diisopropyl ether into acetonitrile. The data crystal was cut from a cluster of crystals and had approximate dimensions; $0.22 \times 0.18 \times 0.11 \mathrm{~mm}$. The data were collected on an Agilent Technologies SuperNova Dual Source diffractometer using a $\mu$-focus $\mathrm{Cu} \operatorname{Ko}$ radiation source $(\lambda=$ $1.5418 \AA$ ) with collimating mirror monochromators. A total of 1001 frames of data were collected using $\omega$-scans with a scan range of $1^{\circ}$ and a counting time of 3 seconds per frame for frames collected with a detector offset of $+/-$ $41.7^{\circ}$ and 12.5 seconds per frame with frames collected with a detector offset of $107.1^{\circ}$. The data were collected at $100 \mathrm{~K}$ using an Oxford Cryostream low temperature device. Details of crystal data, data collection and structure refinement are listed in Table S3. Data collection, unit cell refinement and data reduction were performed using Rigaku Oxford Diffraction's CrysAlisPro V 1.171.41.70a. ${ }^{\mathrm{S} 5}$ The structure was solved by direct methods using $\mathrm{SHELXT}^{\mathrm{S} 6}$ and refined by full-matrix least-squares on $\mathrm{F}^{2}$ with anisotropic displacement parameters for the non- $\mathrm{H}$ atoms using SHELXL-2016/6. ${ }^{\mathrm{S} 7}$ Structure analysis was aided by use of the programs PLATON, ${ }^{\mathrm{S} 8}$ OLEX2 ${ }^{\mathrm{S} 9}$ and WinGX. ${ }^{\mathrm{S} 10}$ The hydrogen atoms on the carbon atoms were calculated in ideal positions with isotropic displacement parameters set to $1.2 \mathrm{xUeq}$ of the attached atom (1.5xUeq for methyl hydrogen atoms). The hydrogen atoms bound to the pyrrole group nitrogen atoms were located in a $\Delta \mathrm{F}$ map and refined with isotropic displacement parameters. The phenyl acetyl group was disordered over two orientations. The disorder impacted a partially occupied molecule of acetonitrile that was correlated with that disorder. The disorder was modeled with features available in OLEX2.

The function, $\Sigma \mathrm{w}\left(\left|\mathrm{F}_{\mathrm{O}}\right|^{2}-\left|\mathrm{F}_{\mathrm{C}}\right|^{2}\right)^{2}$, was minimized, where $\mathrm{w}=1 /\left[\left(\sigma\left(\mathrm{F}_{\mathrm{O}}\right)\right)^{2}+(0.097 * \mathrm{P})^{2}+(1.5896 * \mathrm{P})\right]$ and $\mathrm{P}=\left(\left|\mathrm{F}_{\mathrm{O}}\right|^{2}\right.$ $\left.+2\left|\mathrm{~F}_{\mathrm{C}}\right|^{2}\right) / 3 . \mathrm{R}_{\mathrm{W}}\left(\mathrm{F}^{2}\right)$ refined to 0.181 , with $\mathrm{R}(\mathrm{F})$ equal to 0.0602 and a goodness of fit, $\mathrm{S},=1.14$. Definitions used for calculating $\mathrm{R}(\mathrm{F}), \mathrm{R}_{\mathrm{W}}\left(\mathrm{F}^{2}\right)$ and the goodness of fit, $\mathrm{S}$, are given below. ${ }^{\mathrm{S} 11}$ The data were checked for secondary extinction effects but no correction was necessary. Neutral atom scattering factors and values used to calculate the linear absorption coefficient are from the International Tables for X-ray Crystallography (1992). ${ }^{\mathrm{S} 12}$ All figures were generated using SHELXTL/PC. ${ }^{\text {S13 }}$ CCDC deposition number: 2107227. 
Table S3. Crystal data and structure refinement for $\mathbf{H 1} \cdot \mathrm{LiCl}$

Empirical formula

Formula weight

Temperature

Wavelength

Crystal system

Space group

Unit cell dimensions

Volume

Z

Density (calculated)

Absorption coefficient

$\mathrm{F}(000)$

Crystal size

Theta range for data collection

Index ranges

Reflections collected

Independent reflections

Completeness to theta $=67.684^{\circ}$

Absorption correction

Max. and min. transmission

Refinement method

Data / restraints / parameters

Goodness-of-fit on $\mathrm{F}^{2}$

Final $\mathrm{R}$ indices $[\mathrm{I}>2 \operatorname{sigma}(\mathrm{I})]$

$\mathrm{R}$ indices (all data)

Extinction coefficient

Largest diff. peak and hole

CCDC deposition number
C61.06 H72.58 Cl Li N5.53 O10

1086.22

100.01(11) K

$1.54184 \AA$

triclinic

$\mathrm{P}-1$

$\mathrm{a}=10.9218(4) \AA$

$\alpha=91.337(3)^{\circ}$.

$\mathrm{b}=14.0151(5) \AA$

$\beta=94.946(3)^{\circ}$.

$c=20.4697(5) \AA$

$\gamma=110.901(4)^{\circ}$.
2

$1.239 \mathrm{Mg} / \mathrm{m}^{3}$

$1.084 \mathrm{~mm}^{-1}$

1155

$0.225 \times 0.185 \times 0.112 \mathrm{~mm}^{3}$

3.381 to $73.348^{\circ}$.

$-13<=\mathrm{h}<=13,-17<=\mathrm{k}<=16,-25<=\mathrm{l}<=17$

17926

$11193[\mathrm{R}(\mathrm{int})=0.0232]$

$98.8 \%$

Gaussian

1.000 and 0.793

Full-matrix least-squares on $\mathrm{F}^{2}$

11193 / 104 / 835

1.134

$\mathrm{R} 1=0.0602, \mathrm{wR} 2=0.1740$

$\mathrm{R} 1=0.0678, \mathrm{wR} 2=0.1813$

$\mathrm{n} / \mathrm{a}$

0.913 and -0.444 e. $\AA^{-3}$

2107227 


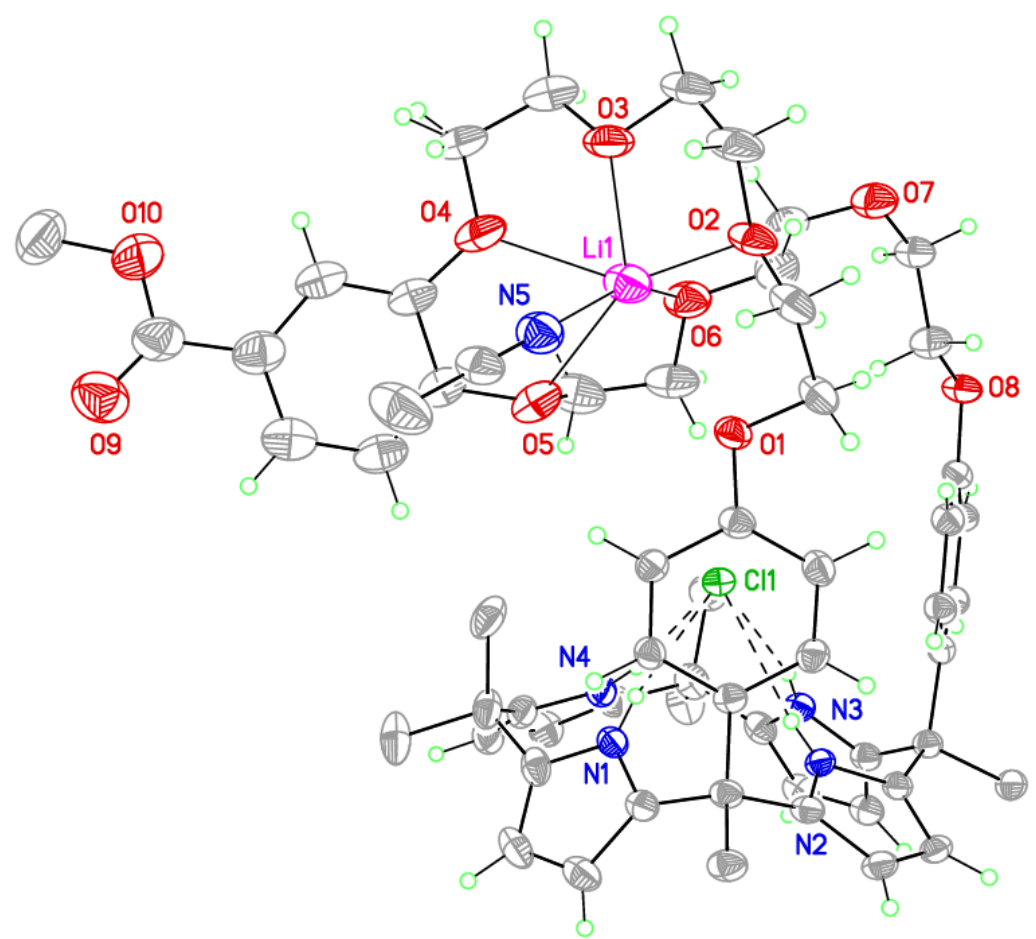

Figure S96. View of $\mathbf{H 1} \cdot \mathrm{LiCl}$ showing the heteroatom labeling scheme. Displacement ellipsoids are scaled to the $50 \%$ probability level. Dashed lines are indicative of a H-bonding interaction. The methyl group $\mathrm{H}$ atoms were omitted for clarity. The lower occupancy atoms of the disordered groups were omitted.

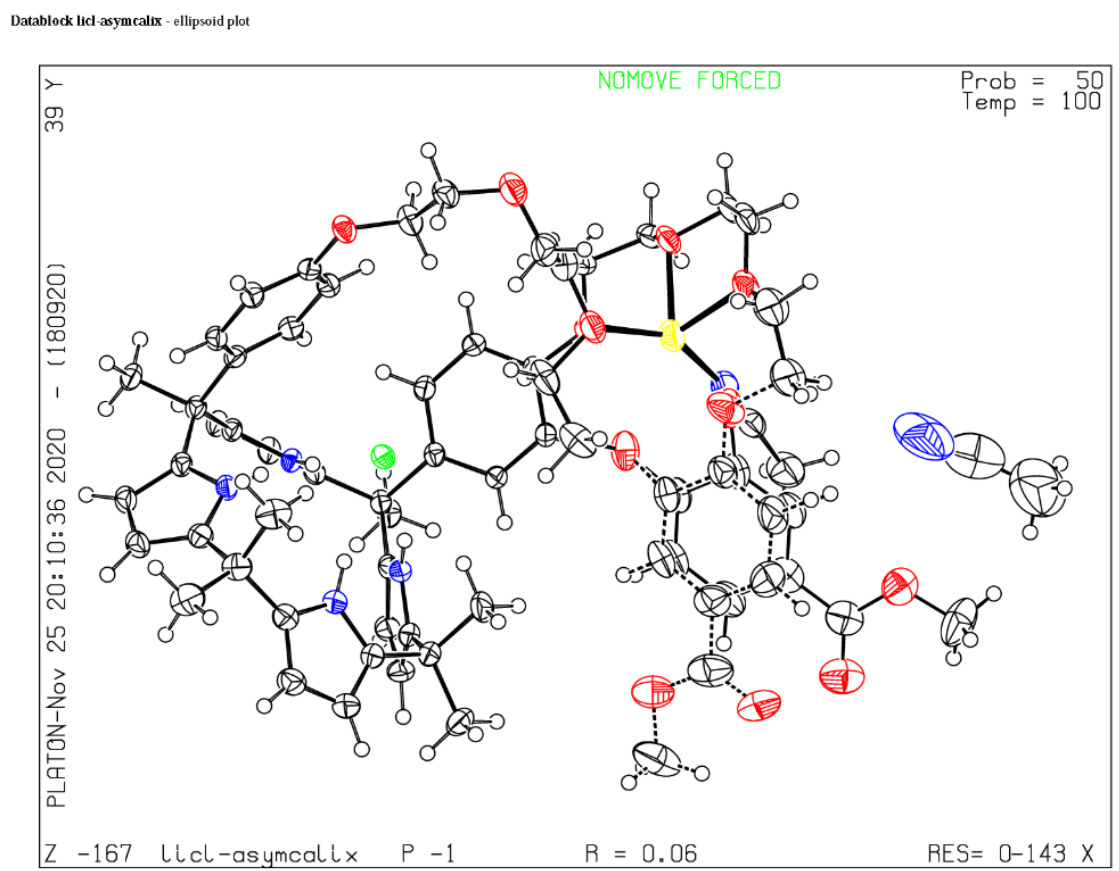

Figure S97. View of H1 $\cdot \mathrm{LiCl}$ showing the heteroatom labeling scheme. Displacement ellipsoids are scaled to the $50 \%$ probability level. Dashed lines are indicative of a H-bonding interaction. The methyl group $\mathrm{H}$ atoms were omitted for clarity. The lower occupancy atoms of the disordered groups were omitted. 
X-ray experimental for the complex $\mathbf{H 2} \cdot \mathrm{LiCl}(\mathrm{CCDC}$ deposition number: 2107218$)$

Crystals grew as clusters of colorless prisms by vapor diffusion of diisopropyl ether into acetonitrile. The data crystal was separated from a cluster of crystals and had approximate dimensions; $0.14 \times 0.10 \times 0.07 \mathrm{~mm}$. The data were collected on an Agilent Technologies SuperNova Dual Source diffractometer using a $\mu$-focus $\mathrm{Cu} \mathrm{K} \alpha$ radiation source $(\lambda=1.5418 \AA)$ with collimating mirror monochromators. A total of 979 frames of data were collected using $\omega$-scans with a scan range of $1^{\circ}$ and a counting time of 10.5 seconds per frame for frames collected with a detector offset of $+/-41.7^{\circ}$ and 37 seconds per frame with frames collected with a detector offset of $107.1^{\circ}$. The data were collected at $100 \mathrm{~K}$ using an Oxford Cryostream low temperature device. Details of crystal data, data collection and structure refinement are listed in Table S4. Data collection, unit cell refinement and data reduction were performed using Rigaku Oxford Diffraction's CrysAlisPro V 1.171.41.70a. ${ }^{\mathrm{S} 5}$ The structure was solved by direct methods using SHELXT $^{\mathrm{S} 6}$ and refined by full-matrix least-squares on $\mathrm{F}^{2}$ with anisotropic displacement parameters for the non- $\mathrm{H}$ atoms using SHELXL-2018/3. ${ }^{\mathrm{S} 7}$ Structure analysis was aided by use of the programs PLATON ${ }^{\mathrm{S} 8}$ and OLEX2. ${ }^{\mathrm{S} 9}$ The hydrogen atoms were calculated in ideal positions with isotropic displacement parameters set to $1.2 \times U$ eq of the attached atom (1.5xUeq for methyl hydrogen atoms). As is typical of these complexes, the methyl-phenyl benzoate group and a portion of the crown ether were disordered. There was a partial acetonitrile molecule in the area where this disorder occurred. The site occupancy for the acetonitrile was tied to that of the minor component of the methylphenyl benzoate group.

The function, $\Sigma \mathrm{w}\left(\left|\mathrm{F}_{\mathrm{O}}\right|^{2}-\left|\mathrm{F}_{\mathrm{c}}\right|^{2}\right)^{2}$, was minimized, where $\mathrm{w}=1 /\left[\left(\sigma\left(\mathrm{F}_{\mathrm{O}}\right)\right)^{2}+\left(0.0968^{*} \mathrm{P}\right)^{2}+(5.3601 * \mathrm{P})\right]$ and $\mathrm{P}=\left(\left|\mathrm{F}_{\mathrm{O}}\right|^{2}\right.$ $\left.+2\left|\mathrm{~F}_{\mathrm{C}}\right|^{2}\right) / 3 . \mathrm{R}_{\mathrm{W}}\left(\mathrm{F}^{2}\right)$ refined to 0.200 , with $\mathrm{R}(\mathrm{F})$ equal to 0.0697 and a goodness of fit, $\mathrm{S},=1.04$. Definitions used for calculating $\mathrm{R}(\mathrm{F}), \mathrm{R}_{\mathrm{W}}\left(\mathrm{F}^{2}\right)$ and the goodness of fit, $\mathrm{S}$, are given below. ${ }^{\mathrm{S} 11}$ The data were checked for secondary extinction effects but no correction was necessary. Neutral atom scattering factors and values used to calculate the linear absorption coefficient are from the International Tables for X-ray Crystallography (1992). ${ }^{\text {S12 }}$ All figures were generated using SHELXTL/PC. ${ }^{\text {S13 }}$ CCDC deposition number: 2107218. 
Table S4. Crystal data and structure refinement for $\mathbf{H 2} \cdot \mathrm{LiCl}$

\begin{tabular}{|c|c|c|}
\hline Identification code & \multicolumn{2}{|l|}{ licl_calix } \\
\hline Empirical formula & \multicolumn{2}{|c|}{ C58.73 H68.73 Cl Li N4.36 O10 } \\
\hline Formula weight & \multicolumn{2}{|l|}{1038.10} \\
\hline Temperature & \multicolumn{2}{|l|}{$99.97(19) \mathrm{K}$} \\
\hline Wavelength & \multicolumn{2}{|l|}{$1.54184 \AA$} \\
\hline Crystal system & \multicolumn{2}{|l|}{ monoclinic } \\
\hline Space group & \multicolumn{2}{|l|}{ P $121 / n 1$} \\
\hline \multirow[t]{3}{*}{ Unit cell dimensions } & $a=14.3795(6) \AA$ & $\alpha=90^{\circ}$. \\
\hline & $\mathrm{b}=19.2240(7) \AA$ & $\beta=101.150(4)^{\circ}$. \\
\hline & $\mathrm{c}=20.1723(8) \AA$ & $\gamma=90^{\circ}$ \\
\hline Volume & \multicolumn{2}{|l|}{$5471.0(4) \AA^{3}$} \\
\hline $\mathrm{Z}$ & \multicolumn{2}{|l|}{4} \\
\hline Density (calculated) & \multicolumn{2}{|l|}{$1.260 \mathrm{Mg} / \mathrm{m}^{3}$} \\
\hline Absorption coefficient & \multicolumn{2}{|l|}{$1.123 \mathrm{~mm}^{-1}$} \\
\hline $\mathrm{F}(000)$ & \multicolumn{2}{|l|}{2207} \\
\hline Crystal size & \multicolumn{2}{|c|}{$0.144 \times 0.098 \times 0.071 \mathrm{~mm}^{3}$} \\
\hline Theta range for data collection & \multicolumn{2}{|l|}{3.205 to $73.525^{\circ}$. } \\
\hline Index ranges & \multicolumn{2}{|c|}{$-13<=\mathrm{h}<=17,-23<=\mathrm{k}<=20,-23<=1<=24$} \\
\hline Reflections collected & \multicolumn{2}{|l|}{29173} \\
\hline Independent reflections & \multicolumn{2}{|c|}{$10744[\mathrm{R}(\mathrm{int})=0.0443]$} \\
\hline Completeness to theta $=67.684^{\circ}$ & \multicolumn{2}{|l|}{$99.9 \%$} \\
\hline Absorption correction & \multicolumn{2}{|c|}{ Gaussian and multi-scan } \\
\hline Max. and min. transmission & \multicolumn{2}{|l|}{1.000 and 0.818} \\
\hline Refinement method & \multicolumn{2}{|c|}{ Full-matrix least-squares on $\mathrm{F}^{2}$} \\
\hline Data / restraints / parameters & \multicolumn{2}{|l|}{10744 / 626 / 896} \\
\hline Goodness-of-fit on $\mathrm{F}^{2}$ & \multicolumn{2}{|l|}{1.027} \\
\hline Final $R$ indices $[I>2 \operatorname{sigma}(I)]$ & \multicolumn{2}{|c|}{$\mathrm{R} 1=0.0697, \mathrm{wR} 2=0.1847$} \\
\hline $\mathrm{R}$ indices (all data) & \multicolumn{2}{|c|}{$\mathrm{R} 1=0.0846, \mathrm{wR} 2=0.2005$} \\
\hline Extinction coefficient & \multicolumn{2}{|l|}{$\mathrm{n} / \mathrm{a}$} \\
\hline Largest diff. peak and hole & \multicolumn{2}{|c|}{0.836 and -0.386 e. $\AA^{-3}$} \\
\hline CCDC deposition number & \multicolumn{2}{|l|}{2107218} \\
\hline
\end{tabular}




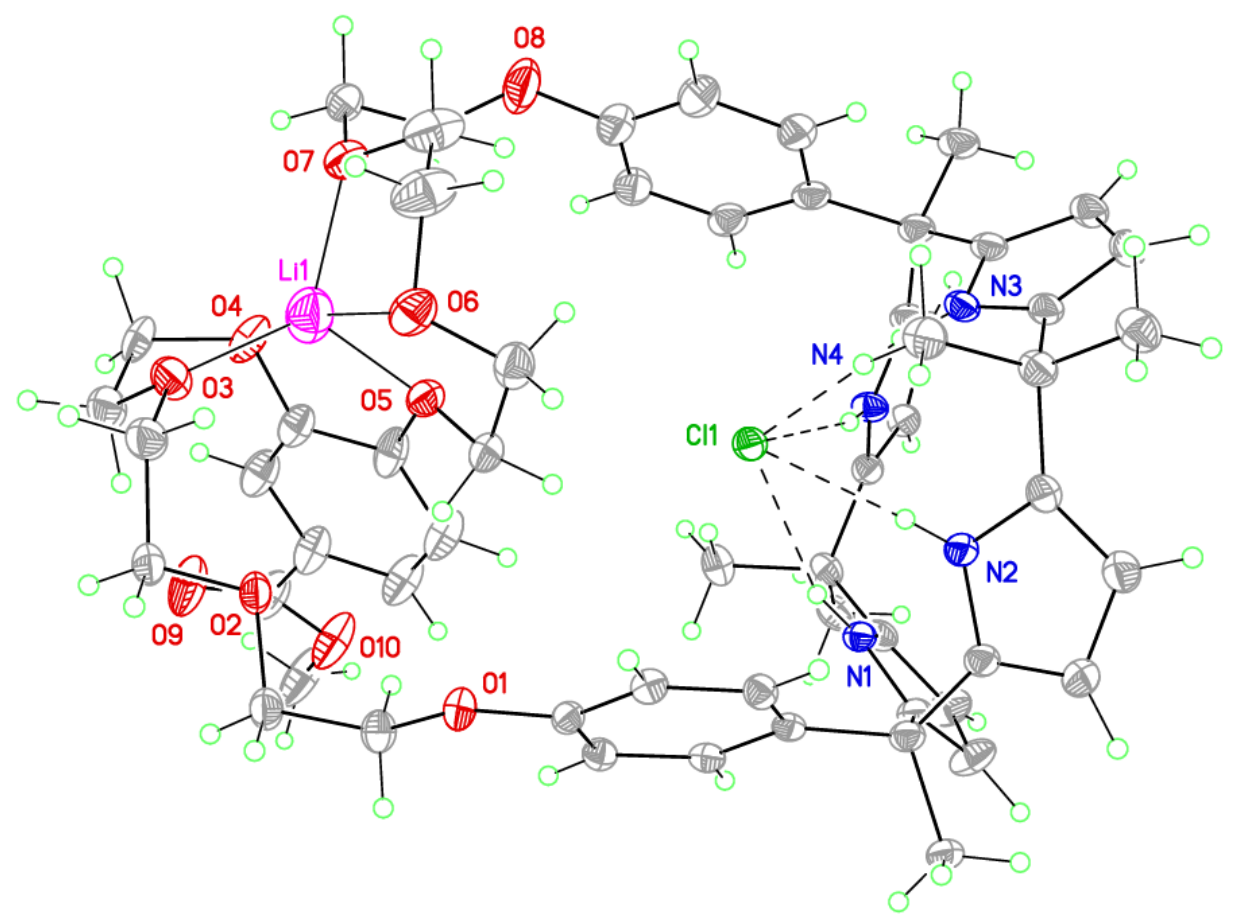

Figure S98. View of the $\mathbf{H 2} \cdot \mathrm{LiCl}$ complex showing the heteroatom labeling scheme. Displacement ellipsoids are scaled to the $30 \%$ probability level. Dashed lines are indicative of a H-bonding interaction. The lower occupancy atoms of the disordered portion of the complex were omitted.

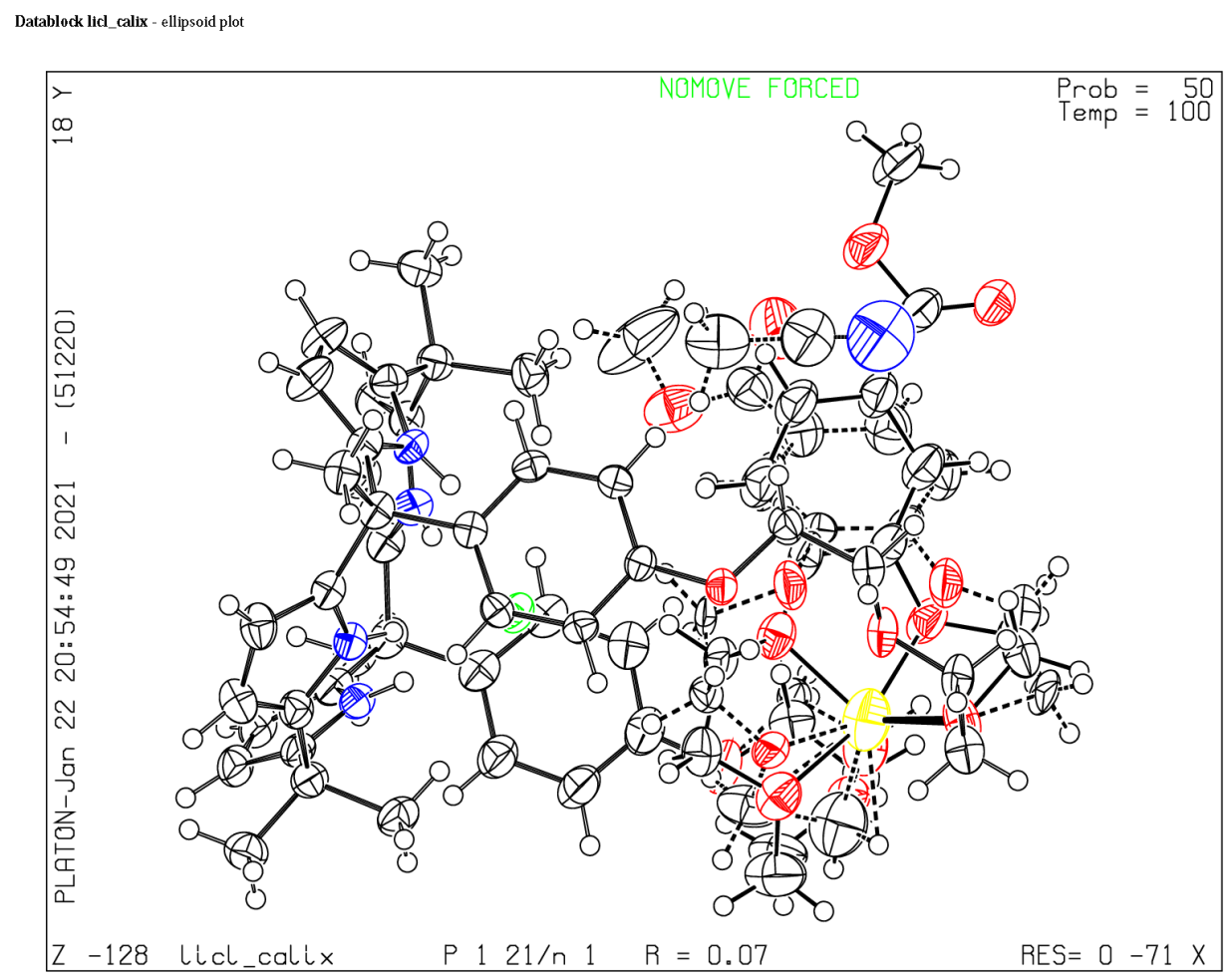

Figure S99. View of the $\mathbf{H 2} \cdot \mathrm{LiCl}$ complex showing the heteroatom labeling scheme. Displacement ellipsoids are scaled to the $50 \%$ probability level. Dashed lines are indicative of a $\mathrm{H}$-bonding interaction. The methyl group $\mathrm{H}$ atoms were omitted for clarity. The lower occupancy atoms of the disordered groups were omitted. 


\section{Computational Methods}

The isomeric structures were drawn, manipulated and energy minimized at the universal force field / molecular mechanics level (UFF/MM) in the Avogadro program (version 1.2.0). These geometries were then optimized with quantum mechanics / density functional theory (DFT) in the Orca program ${ }^{\mathrm{S} 14}$ (version 4.1.0) using the hybrid generalized gradient approximation (GGA) Becke three-parameter Lee-Yang Parr (B3LYP) functional, ${ }^{\text {S15 }}$ the Ahlrich's double zeta basis set ${ }^{\mathrm{S} 16}$ with a polarization function Def2-SVP, and Grimme's third generation dispersion correction with Becke Johnson damping ${ }^{\mathrm{S} 17}$ (D3BJ); the default integration grid of 2 was used for the SCF steps and a final grid of 4 was used for the energy evaluation of the optimized geometries. To speed up the DFT optimizations, the Coulomb integral and numerical chain-of-sphere integration for the HF exchange (RIJCOSX) method ${ }^{\mathrm{S} 18}$ was applied with the Def2/J basis. All structures were optimized in an acetonitrile continuum, specifically: Truhlar's $\mathrm{SMD}^{\mathrm{S} 20, \mathrm{~S} 21}$. In Orca, the effective core potentials (ECPs) are applied to elements in the Periodic Table that are heavier than or includes $\mathrm{Kr}$, so as the structures here involve the lighter elements $\mathrm{C} / \mathrm{O} / \mathrm{N} / \mathrm{H} / \mathrm{Cl} / \mathrm{Li} / \mathrm{Na}$, the calculations are all-electron. The structures were visualized in $\mathrm{ChemCraft}^{\mathrm{S} 22}$ (version b574b). The binding energies for each receptor+salt were referenced to the bare isomers (H1 or H2) that had the most negative energies. The Cartesian coordinates of all optimized structures are freely available under the CC BY 4.0 license on FigShare from the DOI: https://doi.org/10.6084/m9.figshare.16550313.v1. 
Table S5. Energies for $\mathrm{Li}, \mathrm{Na}$ and $\mathrm{Cl}$ ions in an acetonitrile continuum.

\begin{tabular}{|l|l|}
\hline Structure & Energy / Ha \\
\hline $\mathrm{Li}+$ & -7.413819 \\
\hline $\mathrm{Na}+$ & -162.106514 \\
\hline $\mathrm{Cl}-$ & -460.133201 \\
\hline
\end{tabular}

Table S6. Energies for bare $\mathbf{H 1}$ receptors in an acetonitrile continuum.

\begin{tabular}{|l|l|}
\hline Structure & Energy / Ha \\
\hline H1_bare_isomer1 & -3218.408045 \\
\hline H1_bare isomer2 & -3218.407793 \\
\hline H1_bare_isomer3 & -3218.427850 \\
\hline H1_bare isomer4 & -3218.417247 \\
\hline
\end{tabular}

Table S7. Energies for bare $\mathbf{H 2}$ receptors in an acetonitrile continuum.

\begin{tabular}{|l|l|}
\hline Structure & Energy / Ha \\
\hline H2_bare_isomer1 & -3218.422529 \\
\hline H2_bare_isomer2 & -3218.413513 \\
\hline H2_bare_isomer3 & -3218.407852 \\
\hline H2_bare_isomer4 & -3218.400831 \\
\hline
\end{tabular}

Table S8. Absolute energies (Ha) and binding energy differences $\left(\Delta E_{\mathrm{b}}\right)$ of the isomeric $\mathbf{H 1}$ receptors with bound $\mathrm{LiCl}$ in an acetonitrile continuum.

\begin{tabular}{|l|l|l|}
\hline Structure & Energy / Ha & $\Delta \boldsymbol{E}_{\mathbf{b}} / \mathbf{k c a l ~ m o l}^{\mathbf{1}}$ \\
\hline $\mathrm{H} 1+\mathrm{LiCl}$ isomer1 & -3686.134364 & -100.08 \\
\hline $\mathrm{H} 1+\mathrm{LiCl}$ isomer2 & -3686.123824 & -93.47 \\
\hline $\mathrm{H} 1+\mathrm{LiCl}$ isomer3 & -3686.150809 & -110.40 \\
\hline $\mathrm{H} 1+\mathrm{LiCl}$ isomer4 & -3686.131900 & -105.19 \\
\hline
\end{tabular}

Table S9. Absolute energies (Ha) and binding energy differences $\left(\Delta E_{\mathrm{b}}\right)$ of the isomeric $\mathbf{H 1}$ receptors with bound $\mathrm{NaCl}$ in an acetonitrile continuum.

\begin{tabular}{|l|l|l|}
\hline Structure & Energy / Ha & $\Delta E_{\mathrm{b}} / \mathrm{kcal} \mathrm{mol}^{-1}$ \\
\hline $\mathrm{H} 1+\mathrm{NaCl}$ isomer1 & -3840.828693 & -101.11 \\
\hline $\mathrm{H} 1+\mathrm{NaCl}$ isomer2 & -3840.827380 & -100.28 \\
\hline $\mathrm{H} 1+\mathrm{NaCl}$ isomer3 & -3840.830442 & -102.21 \\
\hline $\mathrm{H} 1+\mathrm{NaCl}$ isomer4 & -3840.810809 & -89.89 \\
\hline
\end{tabular}


Table S10. Absolute energies (E/Ha) and binding energy differences $\left(\Delta E_{\mathrm{b}}\right)$ of the isomeric $\mathbf{H} 2$ receptors with bound $\mathrm{LiCl}$ in an acetonitrile continuum.

\begin{tabular}{|l|l|l|}
\hline Structure & E / Ha & $\Delta E_{\mathrm{b}} / \mathrm{kcal} \mathrm{mol}^{-1}$ \\
\hline $\mathrm{H} 2+\mathrm{LiCl}$ isomer1 & -3686.122102 & -95.73 \\
\hline $\mathrm{H} 2+\mathrm{LiCl}$ isomer2 & -3686.153988 & -115.74 \\
\hline $\mathrm{H} 2+\mathrm{LiCl}$ isomer3 & -3686.149376 & -112.84 \\
\hline $\mathrm{H} 2+\mathrm{LiCl}$ isomer4 & -3686.141006 & -107.59 \\
\hline
\end{tabular}

Table S11. Absolute energies (Ha) and binding energy differences $\left(\Delta E_{\mathrm{b}}\right)$ of the isomeric $\mathbf{H 2}$ receptors with bound $\mathrm{NaCl}$ in an acetonitrile continuum.

\begin{tabular}{|l|l|l|}
\hline Structure & Energy / Ha & $\Delta E_{\mathrm{b}} / \mathrm{kcal} \mathrm{mol}^{-1}$ \\
\hline $\mathrm{H} 2+\mathrm{NaCl}$ isomer1 & -3840.811741 & -93.81 \\
\hline $\mathrm{H} 2+\mathrm{NaCl}$ isomer2 & -3840.840393 & -111.79 \\
\hline $\mathrm{H} 2+\mathrm{NaCl}$ isomer3 & -3840.836278 & -109.21 \\
\hline $\mathrm{H} 2+\mathrm{NaCl}$ isomer4 & -3840.833851 & -107.68 \\
\hline
\end{tabular}

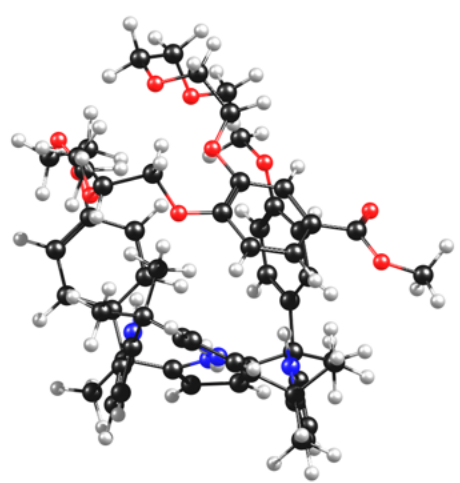

Isomer 1

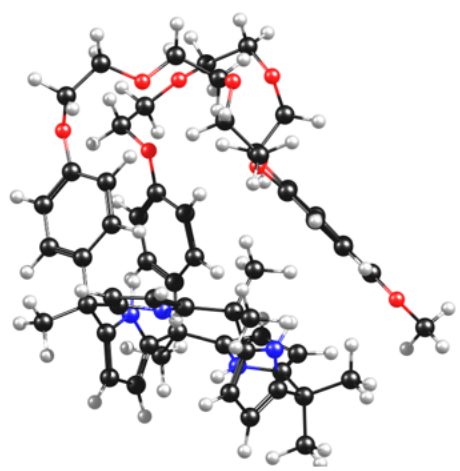

Isomer 3

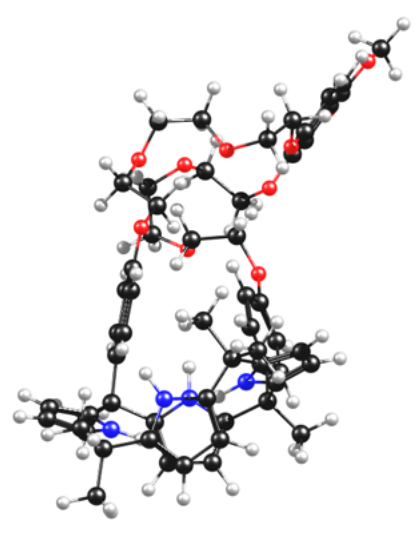

Isomer 2

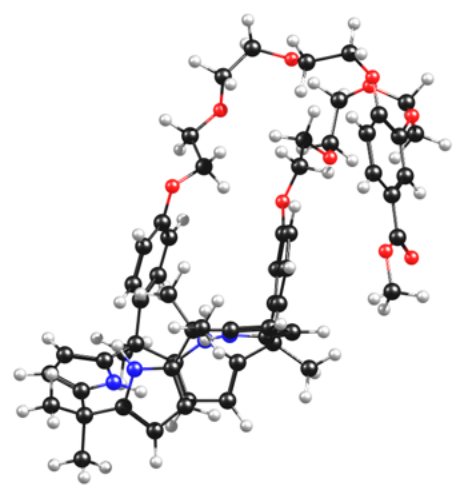

Isomer 4

Figure S100. Structures of the four optimized bare isomers of the H1 receptor. 


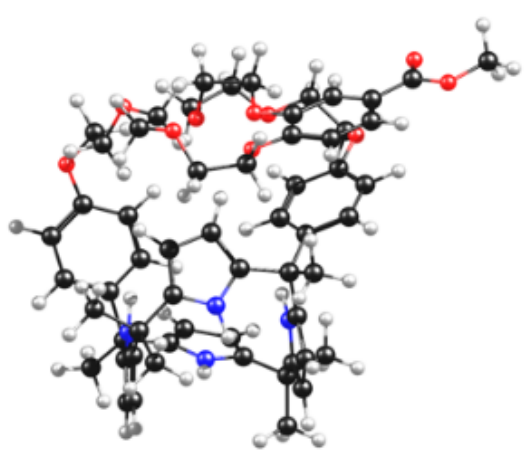

Isomer 1

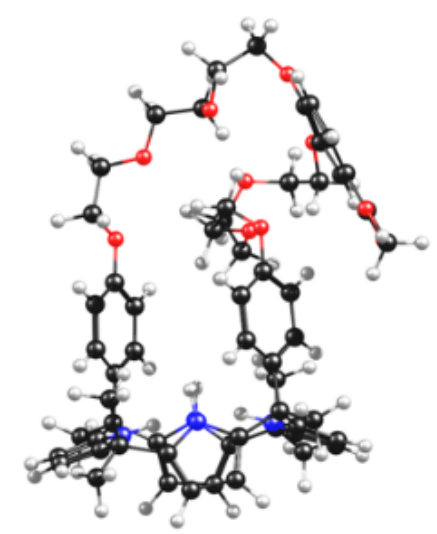

Isomer 3

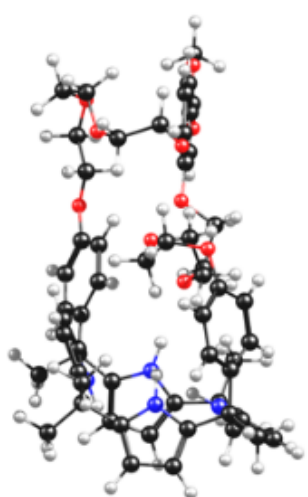

Isomer 2

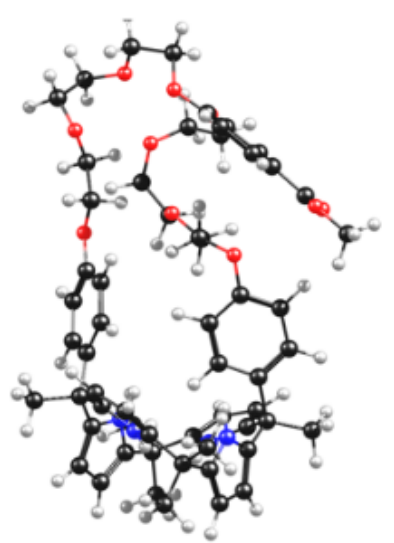

Isomer 4

Figure S101. Structures of the four optimized bare isomers of the $\mathrm{H} 2$ receptor. 


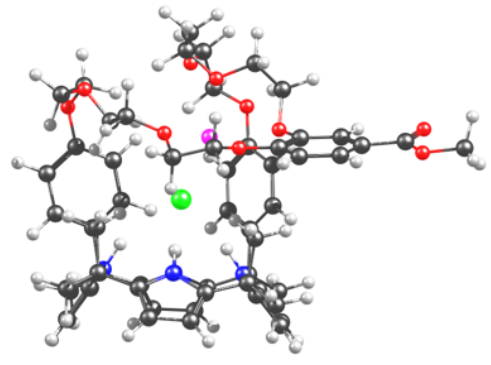

Isomer 1

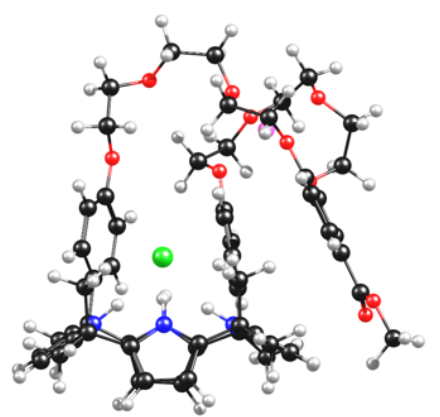

Isomer 3

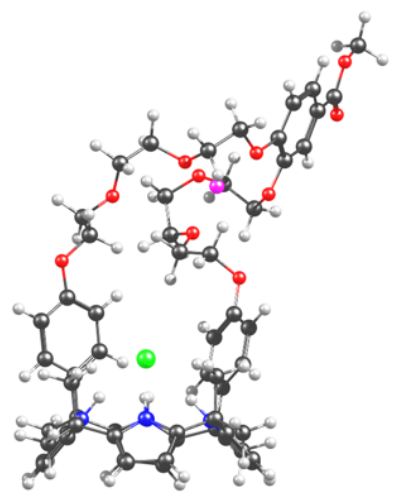

Isomer 2

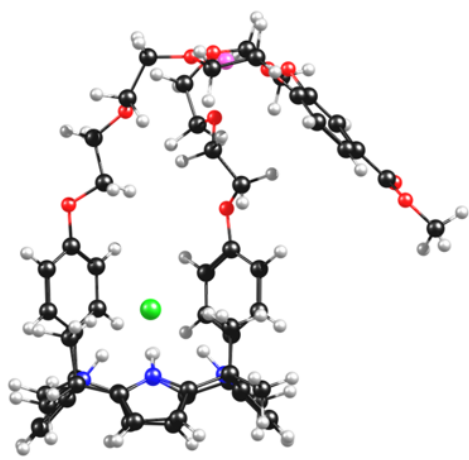

Isomer 4

Figure S102. Structures of the four optimized isomers of the H1 receptor with bound $\mathrm{LiCl}$. 


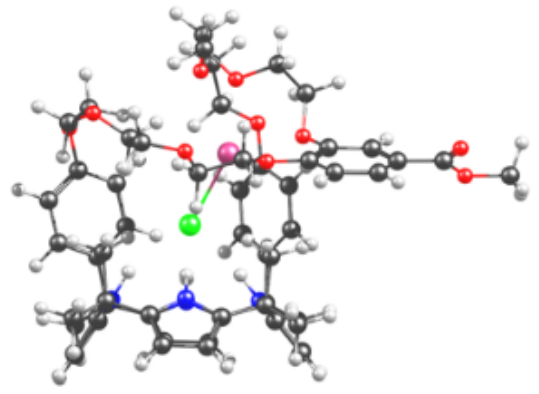

Isomer 1

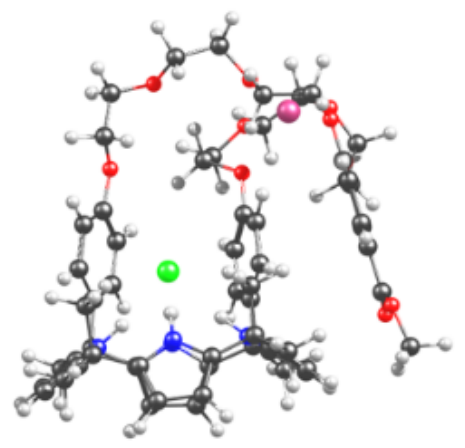

Isomer 3

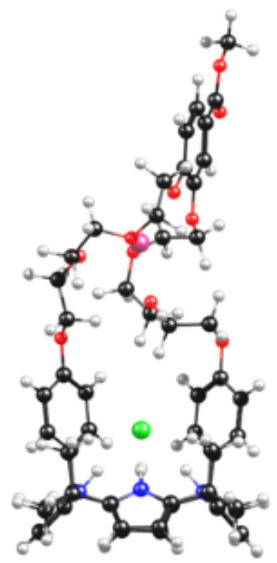

Isomer 2

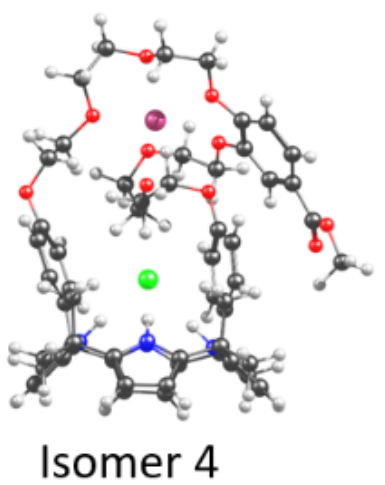

Figure S103. Structures of the four optimized isomers of the $\mathrm{H} 1$ receptor with bound $\mathrm{NaCl}$. 


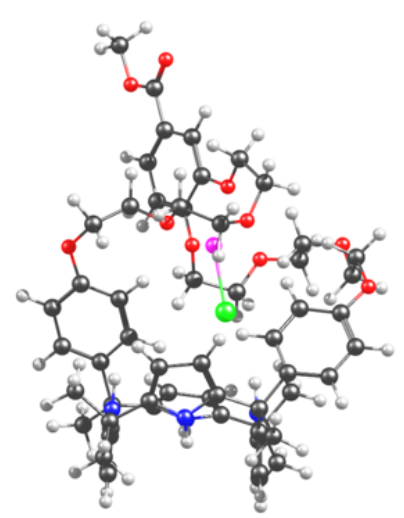

Isomer 1

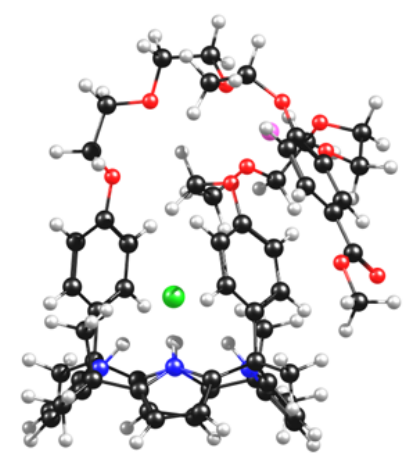

Isomer 3

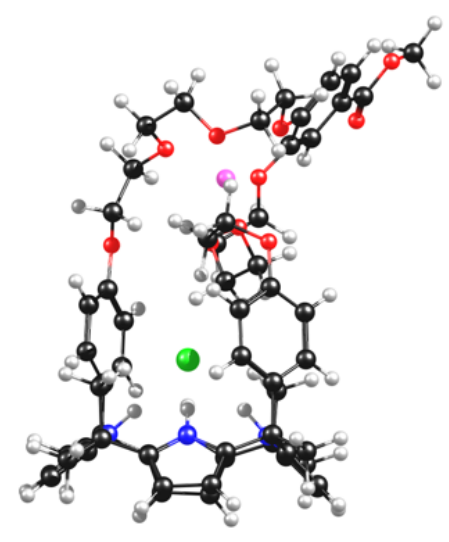

Isomer 2

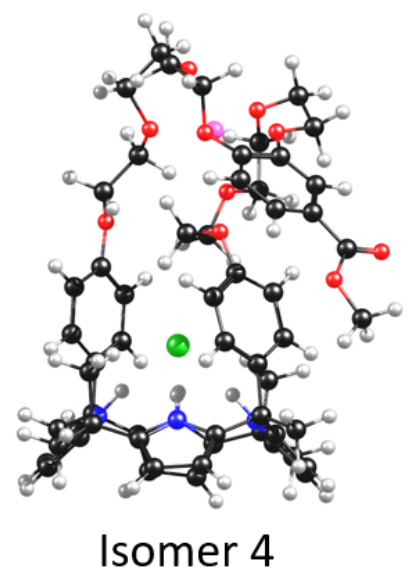

Figure S104. Structures of the four optimized isomers of the $\mathrm{H} 2$ receptor with bound $\mathrm{LiCl}$. 


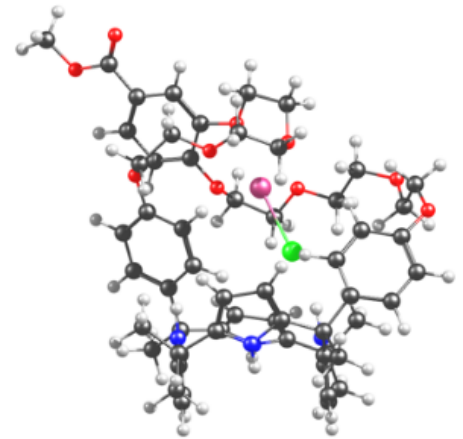

Isomer 1

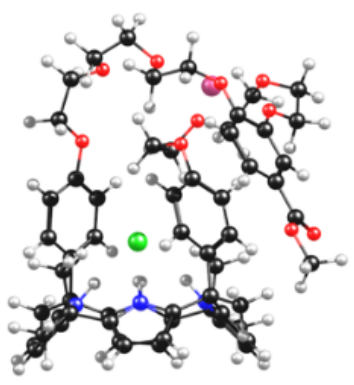

Isomer 3
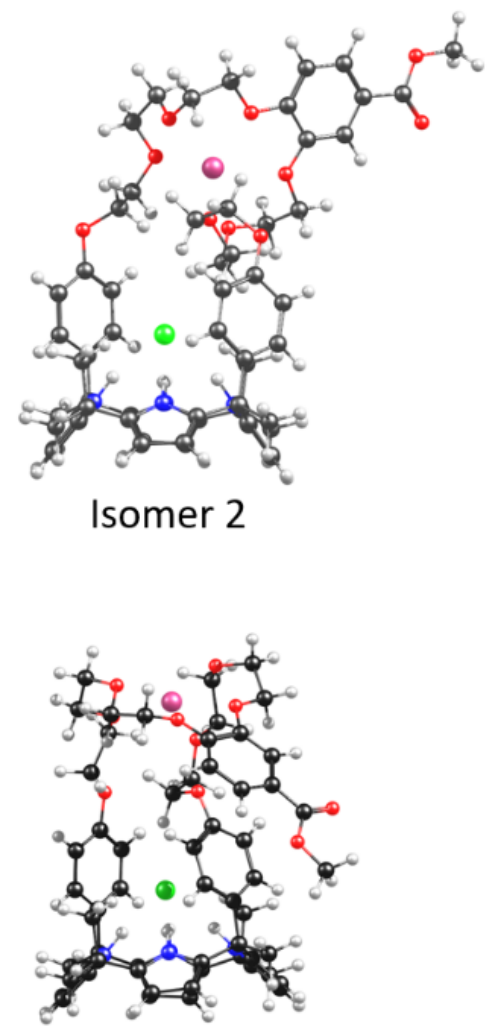

Isomer 4

Figure S105. Structures of the four optimized isomers of the $\mathrm{H} 2$ receptor with bound $\mathrm{NaCl}$. 
25. Supplementary references

S1. Chi, X. D.; Peters, G. M.; Hammel, F.; Brockman, C.; Sessler, J. L. Molecular Recognition Under Interfaial Conditions: Calix[4]pyrrole-Based Cross-linkable Micelles for Ion Pair Extraction. $J$. Am. Chem. Soc. 2017, 139, 9124-9127.

S2. van Ameijde, J.; Liskamp, R. M. Synthesis of Novel Trivalent Amino Acid Glycoconjugates Based on the Cyclotriveratrylene ('CTV') Scaffold. J. Org. Biomol. Chem. 2003, 1, 2661-2669.

S3. Ibrahim, I.; S. Yunus; M. Hashim. Relative Performance of Isopropylamine, Pyrrole and Pyridine as Corrosion Inhibitors for Carbon Steels in Saline Water at Mildly Elevated Temperatures. International Journal of Scientific \& Engineering Research 2013, 4, 1-12.

S4. Haken, J. K.; Werner, R. L. Infrared Spectrum of Polymethyl Acrylate. Br. Polym. J. 1971, 3, $263-265$.

S5. CrysAlisPro. Rigaku Oxford Diffraction (2019). CrysAlicPro Software System, 1.171.41.70a.

S6. Sheldrick, G. M. SHELXT. A Program for Crystal Structure Solution. Acta Cryst. 2015, A71, 38.

S7. Sheldrick, G. M. SHELXL-2016/6. Program for the Refinement of Crystal Structures. Acta Cryst. 2015, C71, 3-8.

S8. Spek, A. L. PLATON, A Multipurpose Crystallographic Tool. Utrecht University, The Netherlands. Acta Cryst. 2009, D65, 148-155.

S9. Dolomanov, O. V., Bourhis, L. J., Gildea, R. J., Howard, J. A. K. and Puschmann, H. OLEX2. A Complete Structure Solution, Refinement and Analysis Program. J. Appl. Cryst. 2009, 42, 339341.

S10. Farrugia, L. J. WinGX 1.64. An Integrated System of Windows Programs for the Solution, Refinement and Analysis of Single Crystal X-ray Diffraction Data. J. Appl. Cryst. 1999, 32, 837838.

S11. $\mathrm{R}_{\mathrm{W}}\left(\mathrm{F}^{2}\right)=\left\{\sum \mathrm{w}\left(\left|\mathrm{F}_{\mathrm{O}}\right|^{2}-\left|\mathrm{F}_{\mathrm{C}}\right|^{2}\right)^{2} / \Sigma \mathrm{w}\left(\left|\mathrm{F}_{\mathrm{O}}\right|\right)^{4}\right\}^{1 / 2}$ where $\mathrm{w}$ is the weight given each reflection.

$\left.\mathrm{R}(\mathrm{F})=\Sigma\left(\left|\mathrm{F}_{\mathrm{O}}\right|-\left|\mathrm{F}_{\mathrm{C}}\right|\right) / \Sigma\left|\mathrm{F}_{\mathrm{O}}\right|\right\}$ for reflections with $\mathrm{F}_{\mathrm{O}}>4\left(\sigma\left(\mathrm{F}_{\mathrm{O}}\right)\right)$.

$\mathrm{S}=\left[\Sigma \mathrm{w}\left(\left|\mathrm{F}_{\mathrm{O}}\right|^{2}-\left|\mathrm{F}_{\mathrm{c}}\right|^{2}\right)^{2} /(\mathrm{n}-\mathrm{p})\right]^{1 / 2}$, where $\mathrm{n}$ is the number of reflections and $\mathrm{p}$ is the number of refined parameters.

S12. International Tables for X-ray Crystallography (1992). Vol. C, Tables 4.2.6.8 and 6.1.1.4, A. J. C. Wilson, editor, Boston: Kluwer Academic Press.

S13. Sheldrick, G. M. SHELXTL/PC (Version 5.03). 1994. Siemens Analytical X-ray Instruments, Inc., Madison, Wisconsin, USA.

S14. Neese, F. The ORCA Program System. Wiley Interdiscip. Rev.: Comput. Mol. Sci. 2012, 2, 73-78.

S15. Becke, A. D. Density Functional Thermochemistry. III. The Role of Exact Exchange. J. Chem. Phys. 1993, 98, 5648-5652. 
S16. Weigend, F.; Ahlrichs, R. Balanced Basis Sets of Split Valence, Triple Zeta Valence and Quadruple Zeta Valence Quality for H To Rn: Design and Assessment of Accuracy. Phys. Chem. Chem. Phys. 2005, 7, 3297-3305.

S17. Grimme, S.; Ehrlich, S.; Goerigk, L. Effect of the damping function in dispersion corrected density functional theory. J. Comput. Chem. 2011, 32, 1456-1465.

S18. Neese, F. An Improvement of The Resolution of The Identity Approximation for the Formation of the Coulomb Matrix. J. Comp. Chem. 2003, 24, 1740-1747.

S19. Izsak, R.; Neese, F. An Overlap Fitted Chain of Spheres Exchange Method. J. Chem. Phys. 2011, $135,144105$.

S20. Pascual-Ahuir, J.; Silla, E. GEPOL: An Improved Description of Molecular Surfaces. I. Building the Spherical Surface Set. J. Comput. Chem. 1990, 11, 1047-1060.

S21. Marenich, A. V.; Cramer, C. J.; Truhlar, D. G. Universal Solvation Model Based on Solute Electron Density and on a Continuum Model of the Solvent Defined by the Bulk Dielectric Constant and Atomic Surface Tensions. J. Phys. Chem. B 2009, 113, 6378-6396.

S22. https://www.chemcraftprog.com 